NUREG/CR- -5435

TI90 008391

\title{
Environmental Effects on \\ Corrosion in the Tuff Repository
}

Manuscript Completed: January 1990

Date Published: February 1990

Prepared by

Dr. J. A. Beavers, Dr. N. G. Thompson

Cortest Columbus, Inc

2704 Sawbury Blvd.

Columbus, OH 43235

Prepared for

Division of Engineering

Office of Nuclear Regulatory Research

U.S. Nuclear Regulatory Commission

Washington, DC 20555

NRC FIN D1692 


\section{DISCLAIMER}

This report was prepared as an account of work sponsored by an agency of the United States Government. Neither the United States Government nor any agency thereof, nor any of their employees, make any warranty, express or implied, or assumes any legal liability or responsibility for the accuracy, completeness, or usefulness of any information, apparatus, product, or process disclosed, or represents that its use would not infringe privately owned rights. Reference herein to any specific commercial product, process, or service by trade name, trademark, manufacturer, or otherwise does not necessarily constitute or imply its endorsement, recommendation, or favoring by the United States Government or any agency thereof. The views and opinions of authors expressed herein do not necessarily state or reflect those of the United States Government or any agency thereof. 


\section{DISCLAIMER}

Portions of this document may be illegible in electronic image products. Images are produced from the best available original document. 
Cortest Columbus is Investigating the long-term performance of container materlals used for high-level waste packages as part of the information needed by the Nuclear Regulatory Commission to assess the Department of Energy's application to construct a geologlc repository for high-level radioactlve waste. The scope of work consists of employing short-term technlques, such as electrochemical and slow strain rate mechanlcal test technlques, to examine a wide range of possible fallure modes. Long-term tests are being used to verify and further examine speciflc fallure modes Identlfled as important by the short-term studles. The original focus of the program was on the salt repository but the emphasis was shifted to the Tuff repository.

This report summarlzes the results of a literature survey performed under Task 1 of the program. The survey focuses on the influence of environmental varlables on the corrosion behavlor of candidate contalner mater 1als for the Tuff repository. Environmental varlables considered Include: radlation, thermal and microblal effects. 


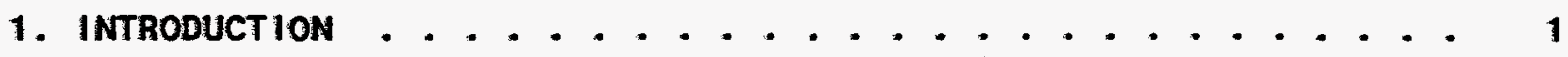

2. THE TUFF REPOSITORY ENVIROMMENT . . . . . . . . . . . . . . 2

2.1 Nominal Environment .................... 2

2.2 Thermal Effects..................... 6

2.3 Radlation Effects ................... 12

2.4 Mlcroblological Effects................. . 19

3. CORROSION BEHAVIOR IN J-13 WELL WATER . . . . . . . . . . . 25

$3.1 \mathrm{Fe}-\mathrm{Cr}-\mathrm{NI}$ Alloys . . . . . . . . . . . . . . . . . . 25

3.1.1 General Corrosion . . . . . . . . . . . . . . 25

3.1 .2 Locallzed Corrosion . . . . . . . . . . . . . . 29

3.1.3 Stress Corrosion Cracking (SCC) . . . . . . . . . . . 34

3.2 Cu Base Alloys . . . . . . . . . . . . . . . . . 40

3.2.1 General Corrosion................ 40

3.2 .2 Localized Corrosion . . . . . . . . . . . . . 53

3.2.3 stress Corrosion Cracking (scc) . . . . . . . . . 61

4. THERMAL EFFECTS ON CORROSION . . . . . . . . . . . . . . . . 63

$4.1 \mathrm{Fe}-\mathrm{Cr}-\mathrm{NI}$ Alloys ....................... . . . 63

4.1.1 General Corrosion . . . . . . . . . . . . . . 63

4.1.2 Locallzed Corrosion ................. . 63

4.1.3 Stress Corrosion Cracking (SCC) . . . . . . . . . 69

4.2 Cu-Base Alloys . . . . . . . . . . . . . . . . . 72

4.2.1 General Corrosion... . . . . . . . . . . . 72

4.2.2 Locallzed Corrosion . . . . . . . . . . . . . . 72

4.2.3 Stress Corrosion Cracking (SCC)........... 72 
Page

5. RADIATION EFFECTS ON CORROSION . . . . . . . . . . . . . . . . 75

$5.1 \mathrm{Fe}-\mathrm{Cr}-\mathrm{NI}$ Alloys ...................... . . 75

5.1.1 General Corrosion................ 75

5.1.2 Locallzed Corrosion ................ 75

5.1.3 stress Corrosion Cracking (SCC). . . . . . . . 85

5.2 Cu-Base Alloys .................... . 88

5.2.1 General Corrosion................. 88

5.2.2 Locallzed Corrosion................. 93

5.2.3 Stress Corrosion CrackIng (SCC) . . . . . . . . . 101

6. MICROBIOLOGICAL EFFECTS ON CORROSION . . . . . . . . . . . 102

$6.1 \mathrm{Fe}-\mathrm{Cr}-\mathrm{NI}$ Alloys . . . . . . . . . . . . . . . . . . 102

6.1.1 General Corrosion............... . 102

6.1 .2 Locallzed Corrosion ................ . 102

6.1.3 Stress Corrosion Cracking (SCC)........... 105

6.2 Cu-Base Alloys . . . . . . . . . . . . . . . . . 108

6.2.1 General Corrosion . . . . . . . . . . . . 108

6.2.2 Locallzed Corrosion . . . . . . . . . . . . 108

6.2.3 Stress Corrosion Cracking (SCC) .......... 110

7. DISCUSSION AND CONCLUSIONS . . . . . . . . . . . . . . . . . . . 111

$7.1 \mathrm{Fe}-\mathrm{Cr}-\mathrm{NI}$ Alloys........................ 111

7.2 Cu-Base Alloys . . . . . . . . . . . . . . . . . . 112

8. RECOMMENDATIONS . . . . . . . . . . . . . . . . . . . . . 114

8.1 Task 2 - Potentlodynamic Polarization Studles . . . . . . . . 114

8.2 Task 3 - Vapor Phase Corrosion Studles . . . . . . . . . . . 114

8.3 Task 4 - Plttlng Studies . . . . . . . . . . . . . . . . 114 
Page

8.4 Task 5 - stress corrosion Cracklng studies . . . . . . . . 115

8.5 Task 6 - Other Fallure Modes . . . . . . . . . . . . 116

8.6 Task 7 - Long-Term Exposure Studles . . . . . . . . . . . 116

APPENDIX A . . . . . . . . . . . . . . . . . . . . . . . A1

APPENDIX B . . . . . . . . . . . . . . . . . . . . . . B1

REFERENCES . . . . . . . . . . . . . . . . . . . . . . . . . R1 
Flgure 2.1 Representative Stratlgraphlc Section In Nevada Tuff (Drillhole UE 25 a-1). (McCrlght-1984) . . . . . . .

Figure 2.2 Comparative Canister Surface Temperature-Time Proflles For Different Waste Packages In A Tuff Repository (Vertical Emplacement, $50 \mathrm{~kW} / \mathrm{acre}$ Areal Loading). (McCrlght-1984)..............

Figure 2.3 Temperature HIstorles of A Spent Fuel Waste Package In Tuff. The 70-cin Dlameter Package Contains 10-Year Aged PWR Fuel With Thermal Power of $3.3 \mathrm{~kW}$, Vertlcally Emplaced In An Array With Areal Power Density of $57 \mathrm{kw} / a c r e . \quad($ Acton-1986) . . . . . . . . .

Figure 2.4 Sillicon And Sodium Concentrations In J-13 Water Reacted With Crushed G-1 Materlal At $150^{\circ} \mathrm{C}$ As A Function of TIme In Days. (Knauss-1985a)

Figure 2.5 Aluminum, Potassium, Calclum, Magneslum, and pH Analyses From J-13 Water Reacted With Crushed G-1 Material At $150^{\circ} \mathrm{C}$ As A Function of Time In Days. (Knauss-1985a)

Figure 2.6 Concentration Changes In J-13 Water During Reaction With Crushed Tuff At $100^{\circ} \mathrm{C}$. (Abraham-1986) . . . . . 14

Figure 2.7 Concentration Changes In 10x J-13 Water During Reaction With Crushed Tuff At $100^{\circ} \mathrm{C}$. (Abraham-1986)

Figure 2.8 Gas Pressure Variation In Vessel T-1 (95 $\left.{ }^{\circ} \mathrm{C}\right)$ During

The Last 3-3/4 Months of The 7-Month Experiment. The Average Rate of Pressure Increase Is $1.0 \mathrm{psi} / \mathrm{day}$ $(6.9 \mathrm{kPa} /$ day). The Letters Ident Ify The Samples shown In Table 2.6. (Yunker-1986a)

Figure 3.1 Electrochemical Determinatlons of Corrosion Rates For Different Alloys in Tuff-Condltioned J-13 Water At $100^{\circ} \mathrm{C}$. (McCrlght-1984) . . . . . . . . . .

Figure 3.2 Potentiodynamic Anodic Polarization Curve For 304L In J-13 Well Water At $90^{\circ} \mathrm{C}$. Scan Rate Was $1 \mathrm{mV} / \mathrm{s}$. Scan Starts From Ecor. (Glass-1984) . . . . . . . . .

Figure 3.3 Electrochemlcal Parameters For 304L In Tuff-Conditloned J-13 Well Water As A Function of Temperature. All Potentials Are Referenced To An S.C.E. At $25^{\circ} \mathrm{C}$. (Glass-1984) 
Page

Figure 3.4 Electrochemical Parameters For 316L Analogous To Those of Flgure 3.3 For 304L. (Glass-1984) . . . . . . 32

Figure 3.5 Electrochemical Parameters For 1-825 Analogous To Those of Flgure 3.3 for 304L. (Glass-1984) . . . . . . 33

FIgure 3.6 Schematlc TIme, Temperature, Sensitization (TTS)

Dlagram. (Juhas-1984) . . . . . . . . . . . 35

Figure 3.7 Computer SImulation of Type 304 Stainless Steel

Canister. Thermal History Showing Welding, Glass-Pour Ing, And Storage. (Juhas-1984) . . . . . . 36

Figure 3.8 Polarization Behavior of CDA 613 in $\mathrm{J}-13$ Water At $80^{\circ} \mathrm{C}$. (McCrIght-1985) . . . . . . . . . . 54

Figure 3.9 Values of The Passive State Current Density For J-13 And $100 \times$ Concentrated J-13 At Different

Temperatures. $*=100 \times \mathrm{J}-13$. (McCright-1985) ... . 55

Figure 3.10 Corrosion Rates in $\mathrm{J}-13$ And $100 \times$ Concentrated $\mathrm{J}-13$

As A Function of Temperature. $*=100 \times \mathrm{J}-13$.

(McCrlght-1985) . . . . . . . . . . . . 56

Figure 3.11 Polarization behavior of CDA 715 In J-13 Water At $80^{\circ} \mathrm{C}$. (McCright-1985) ............ 57

Figure 3.12 Corrosion Potentials in J-13 And 100x Concentrated J-13 At Different Temperatures. $*=100 \times \mathrm{J}-13$. (McCrIght-1985) . . . . . . . . . . . . . 58

Figure 3.13 Pitting Potentials in J-13 and 100x Concentrated J-13 At Different Temperatures. $*+100 \times \mathrm{J}-13$. (McCright-1985) ................. 59

Figure 3.14 Values For Separation of Pitting And Corrosion Potentials in $\mathrm{J}-13$ And $100 \times$ Concentrated J-13 At Different Temperatures. $*=100 \times \mathrm{J}-13$. (McCright-1985)

Figure 4.1 Corrosion Rates For Candidate Alloys In Tuff-Conditioned J-13 Well Water At Different Temperatures. The Tafel Extrapolation Method Was Used. (Glass-1984) . . . . . . . . . . . . 65

FIgure 4.2 Electrochemical Corrosion Rates For 304L In TuffConditloned $\mathrm{J}-13 \mathrm{Well}$ Water At $90^{\circ} \mathrm{C}$ WIth Different Concentrations of Added $\mathrm{NaCl}$. (Glass-1984) 
Page

Figure 4.3 Corrosion Potentlals And Protection Potentials For 304L Stainless Steel In Tuff-Conditloned J-13 Water At Different Temperatures. (McCrIght-1984) . . . . . 67

Figure 4.4 Corrosion Potentlals And Protection Potentials For 316L Stainless Steel In Tuff-Condltioned J-13 Water At Different Temperatures. (McCrIght-1984) . . . . 67

Figure 4.5 Corrosion Potentlals And Protection Potentials For 321 Stainless steel In Tuff-Condltloned $J-13$ Water At Different Temperatures. (McCright-1984) . . . . . 68

Figure 4.6 Corrosion Potentials And Protection Potentlals For Alloy 825 in Tuff-Conditloned $\mathrm{J}-13$ Water At Different Temperatures. (McCrIght-1984)....... 68

Flgure 4.7 Effect of Temperature on Time To Fallure In $0.05 \mathrm{M}$ $\mathrm{CuSO}_{4}, 1 \mathrm{M}\left(\mathrm{NH}_{4}\right)_{2} \mathrm{SO}_{4}, \mathrm{pH} 6.5$. (UhIlg-1975)....... 74

Figure 5.1 Corrosion Potentlal Behavior For Alsi 316L Stainless Steel In $10 \mathrm{X}$ Concentrated $\mathrm{J}-13$ Well Water Under Gamma Irradiation. The Solution Was Not Exposed To Irradiation Prior To Inltiation of The FIrst "On/Off" Irradlation Cycle. (Glass-1986a) . . . . . 79

Figure 5.2 Corrosion Potential Behavior For AlSI 316L Stainless Steel In Gamma-Irradiated J-13 Well Water. Following The "Off" HalfCycle The Irradiated Solution Was Decanted And Replaced By A Fresh, Unirradlated Solution. Following This, $\mathrm{H}_{2} \mathrm{O}_{2}$ Was Added To Solution At A Concentration of $0.4 \mathrm{mM}$. (Glass-1986a) . .

Figure 5.3 Response of The Corrosion Potentlal For AlSI 316L Stainless Steel In Unirradlated $\mathrm{J}-13$ Well Water To Which Successive Additions of $\mathrm{H}_{2} \mathrm{O}_{2}$ Were Made. In This Figure, One Drop of $\mathrm{H}_{2} \mathrm{O}_{2}$ (From A 30\% solution) Represents A Resulting Solution Concentration of 0.5 $\mathrm{mM}$. The Solution Was Cont Inuously stirred By $A$ Magnetic Stirrer Throughout The Experiment. (Glass-1986a)

Figure 5.4 Comparison of The Potent lodynamic Anodic Polarization Behavior For 316L Stainless steel In $0.018 \mathrm{M} \mathrm{NaCl}$ Solution In Deionlzed Water With And Without Gamma Irradiation ( $\square$, UnIrradlated; 0 , Irradlated). (Glass-1986b) 
Figure 5.5 Comparison of The Potentlostatic Anodic Polarization

Behavior For $316 \mathrm{~L}$ stalnless steel in $650 \mathrm{ppm} \mathrm{Cl}^{-}$

Solution In Delonlzed Water WIth And WIthout Gamma

Irradlation. (Glass-1985) ............. 84

Figure 5.6 Weight Loss Vs. Time For CDA 101, Pure Copper Specimens.

(Yunker-1986b) . . . . . . . . . . . . . . 95

Figure 5.7 Weight Loss Vs. TIme For CDA 613, Aluminum Bronze

Specimens. (Yunker-1986b) . . . . . . . . . . . . . 95

Figure 5.8 Welght Loss Vs. TIme For CDA 715, Nickel-Copper

Specimens. (Yunker-1986b) . . . . . . . . . . . . 96

FIgure 5.9 Polarization Curves For CDA 102 In 20X J-13 Water At

$90^{\circ} \mathrm{C}$ Both out of And In Gamma Radlation Fleld.

(Acton-1986) . . . . . . . . . . . . . . . . . 98

Figure 5.10 Corrosion Potentlal Behavior For CDA 102 Copper

Irradlated in J-13 Well Water At $3.3 \mathrm{Mrad} / \mathrm{hr}$.

(Glass-1986a) . . . . . . . . . . . . . . 99

Figure 5.11 Response of The Corrosion Potential For CDA 102

Copper In Irradiated J-13 Well Water To Whlch One

Drop of $30 \% \mathrm{H}_{2} \mathrm{O}_{2}$ Solution Was Added, Corresponding

To A Solution Concentration of $0.5 \mathrm{mM}$. The

Solution Was StIrred UntII Indicated on The Figure.

(Glass-1986a) . . . . . . . . . . . . . 100

Figure 6.1 Electron Probe Microanalyses Elemental Plots Across

A Typlcal Crack In A Rough Sanded Cross-Sectional

Pitted Specimen From The Tank Wall. Top Line

Deplcts SIIIcon Content, Middle Line Deplcts Sulfur

Content And Bottom Line Depicts Chlorine Content.

(Stoecker-1986) . . . . . . . . . . . . . 106

Figure 6.2 The Effect of Sulfide Concentration of Flowing

Seawater $(2.4 \mathrm{~m} / \mathrm{s})$ on Pitting of Copper-10 Nickel

And Copper-30 NICkel. (Gudas-1978) . . . . . . . 109

Figure A.1 Schematic of Typical Anodic Potentlodynamic

Polarlzation Curve................. A2

Figure A.2 Typlcal Test Equipment For Performing The PP Test . . . A4 
$6 \varepsilon$

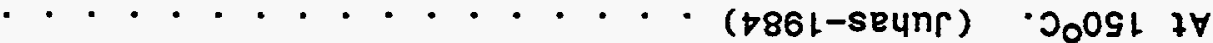

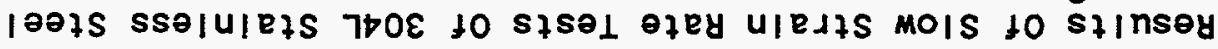

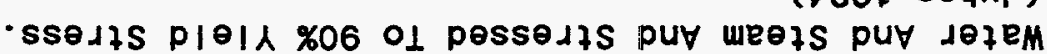

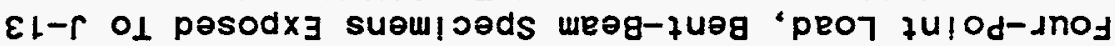

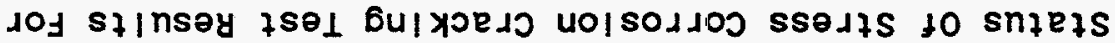

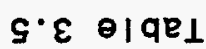

$\nabla \cdot \varepsilon \cdot \theta_{1}$

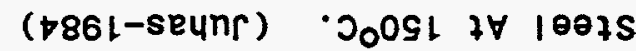
sselulezs toE to szsel ofey Uledzs mols to stinsoy

$\varepsilon \cdot \varepsilon \cdot \theta \mid q e_{\perp}$

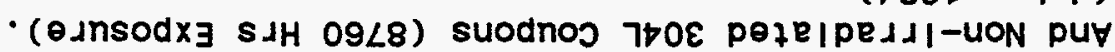

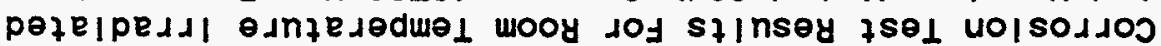

$\tau \cdot \varepsilon \ominus \nabla R_{\perp}$

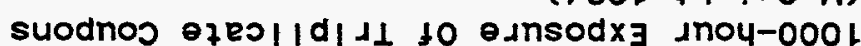

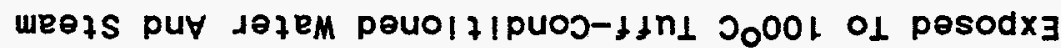

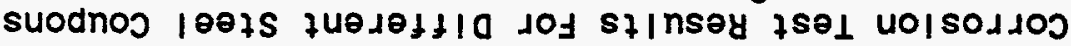

$L^{\cdot} \varepsilon$ $\theta \mid q e_{\perp}$

$\nabla \tau$

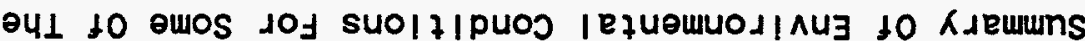

¿2

- GuIInoj pur uolsodjos $47 \mathrm{IM}$ pefe!joss squemuodinus

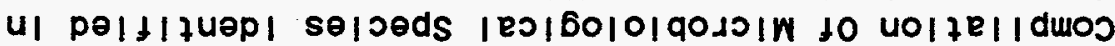

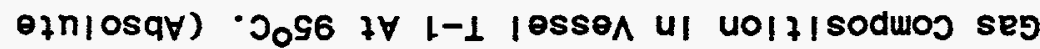

(eg861-jexund)

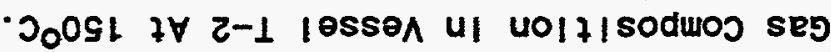

$\varepsilon$ L

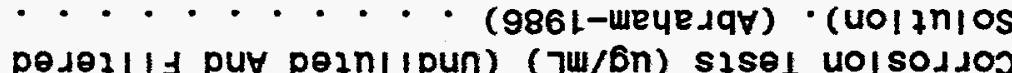

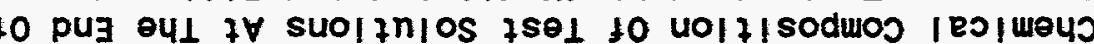

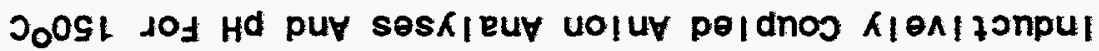

g

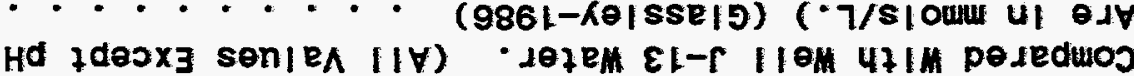
esen deluley 10 ouoz pezednzesun wodj defem louunl

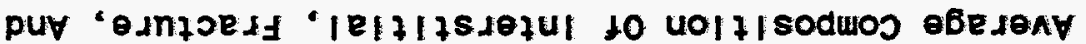

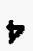

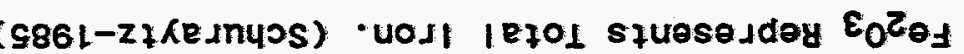

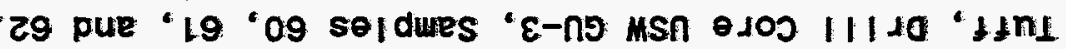
sbul jds yedodol ul squentifsuos dolen to sebequesded
$L \cdot \tau \theta \mid q e_{\perp}$

$9 \cdot 2 \theta \mid q R_{\perp}$

S. 2 ध|qe1

$\varepsilon \cdot \tau \theta \mid q e_{1}$

$z \cdot \tau \operatorname{elqR} 1$

$6^{\circ} 2$ ? $\mid q \mathbb{P}_{\perp}$

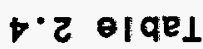

$1 \cdot 2$ OIRI 
Table 3.6 Slow-Strain-Rate Test Results For Type 304 Stainless

steel At $150^{\circ} \mathrm{C}$. (PItman-1986) ........... 41

Table 3.7 Slow-strain-Rate Test Results For Type $304 \mathrm{~L}$ Stainless

Steel At $150^{\circ} \mathrm{C}$ (P|tman-1986) ............. 42

Table 3.8 Slow-Straln-Rate Test Results For Type 304 And Type $316 \mathrm{~L}$ stalnless Steel at $95^{\circ} \mathrm{C}$ And A straln Rate of $1 x$ $10^{-6} /$ s. (PItman-1986) ............... 43

Table 3.9 Vendor Supplled Chemical Analysls of Test Alloys

(Welght Percent). (Abraham-1986) . . . . . . . . 44

Table 3.10 Test Matrlx For Stress Corrosion of Candldate Stainless steel And Incoloy-825. (Abraham-1986) .... 45

Table 3.11 Stress Corrosion Cracking Tests For Type $304 \mathrm{~L}$

Stainless Steel. (Abraham-1986) ........... 46

Table 3.12 Stress Corrosion Cracking Tests for Type 316L

Stalnless Steel. (Abraham-1986) ........... 47

Table 3.13 Stress Corrosion Cracking Tests For Type 321

Stalnless Steel. (Abraham-1986)........... 48

Table 3.14 stress Corrosion Cracking Tests For Incoloy 825. (Abraham-1986) . . . . . . . . . . . . . 49

Table 3.15 Composition of J-13 And $10 \times \mathrm{J}-13$ Solution During Stress Corrosion Exper Iments. (Abraham-1986) ..... 50

Table 3.16 Actual Analyses of Copper Alloys Used In Corrosion Tests. (McCrlght-1985) . . . . . . . . . . .

Table 3.17 General Corrosion Penetration Rates of Candidate Copper-Base Materlals And Other Materlals, For Comparison, In Tuff Repository Environmental Condltions. (McCrlght-1985)

Table 3.18 summary of Environments Known To Promote stress Corrosion Cracking of Copper-Base Alloys . . . . . . 62

Table 4.1 Corrosion Rates of Candldate Stainless steels in J-13 Water As Determined From Weight-Loss Data. (Glass-1984) .................. 64

Table 4.2 Sensitization Heat Treatments For Boildown Test. (PItman-1986) 
Table 4.3 Chemical Composition of Test Solutions At The End of Corrosion Tests $(u g / m L$ ) (undliluted and flltered solution). (Abraham-1986)............ 71

Table 5.1 Corrosion Test Results For Carbon, Alloy And Stainless Steel Coupons In Radlated Environments (2-Month Exposure Data). (MCCrlght-1984) ...........

Table 5.2 Corrosion Test Results For Different Steel Coupons Exposed To $100^{\circ} \mathrm{C}$ Tuff-Conditloned Water And Steam 1000-hour Exposure of Tr|plicate Coupons.

(McCrlght-1984).................

Table 5.3 Corrosion Test Results For Room Temperature Irradlated And Non-Irradlated $304 \mathrm{~L}$ Coupons ( $8760 \mathrm{Hrs}$ Exposure).

Table 5.4 Chemical Compositlons And Mechanlcal Propertles of Stainless steel Test Materlals. (P|tman-1986)

Table 5.5 Summary of Irradlation-Corrosion Test Data. (PItman-1986) ...................

Table 5.6 Composition of Corrosion Speclmens. (Yunker-1986a)...

Table 5.7 Uniform Corrosion Rate Determinations For Copper And Copper-Base Alloys Under Strongly Irradiated Conditions (ca. $10^{5} \mathrm{rads} / \mathrm{hr}$ ). (Acton-1986)

Table 5.8 Comparison of Corrosion Rates For Copper And Copper-Base Alloys In Irradlated And Non-Irradlated Environments, mils/yr. (Acton-1986)

Table 5.9 Weight Loss And Unlform Corrosion Rates.

(Yunker-1986b)

Table 6.1 Summary of Several Case Histories Of MIC Reported In The Open LIterature

Table 6.2 Water Analyses. (Stoecker-1986) . . . . . . . . 104

Table 6.3 Composition of Water Samples From Heat Exchangers. (Pope-1982)

Table B.1 Concentration Ranges For Environmental Species in

Table B.2 List of Varlables To Be Included In The Resolution IV Matrix of Potent lodynamic Polarization Tests In Task 2........................ 
Cortest Columbus, Inc., Is Investlgating the long-term performance of contalner materlals used for high-level waste packages as part of the Information needed by the Nuclear Regulatory Commission to assess the Department of Energy's (DOEs) application to construct a geologlc repository for high-level radloactive waste. The scope of work consists of employing short-term technlques, such as electrochemlcal and slow strain rate mechanlcal test technlques, to examine a wlde range of possible fallure modes. Long-term tests are being used to verlfy and further examine speclfic fallure modes Identifled as Important by the short-term studles. The orlginal focus of the program was on the salt repository, but the emphasls was shifted to the Tuff repository.

This report summarizes the results of a survey of the literature performed under Task 1 of the program. The purpose of Task 1 is to complle repository site-specific data that are necessary to develop and update the work plan, to provide cont Inulty between the individual tasks of the prolect and to coordinate the project with other NRC projects.

The focus of the survey is the Influence of environmental varlables on the corrosion behavior of candidate contalner materlals for the Tuff repository. Two classes of alloys have been evaluated by DOE for use as a contalner material In the Tuff repository; $\mathrm{Fe}-\mathrm{Cr}-\mathrm{NI}$ alloys and copper-base alloys. The primary candldate $\mathrm{Fe}-\mathrm{Cr}-\mathrm{NI}$ alloys are Type $304 \mathrm{~L}$ stainless steel, Type 316L stainless steel and Incoloy Alloy 825. The primary candidate copper-base alloys are CDA 102 (pure copper), CDA 613 (aluminum bronze), and CDA 715 (copper-30 nickel). The environmental parameters considered in this report are thermal effects, radlation effects and microblological effects.

The Fe-Cr-NI alloys were found to be highly resistant to general corrosion under ant Iclpated repository conditions, but the austenitic stainiess steels (Types 304 and 316 stainless steels) were found to be potentlally susceptible to localized forms of corrosion. For this class of alloys, propagation rates for locallzed corrosion (pltting and crevice corrosion) are probably too high to provide adequate contalner Ilfe if It initiates.

The most serlous problem for the austenltic stalnless steels is stress corrosion cracking (SCC). Transgranular stress corrosion cracking (TSCC) was observed for Type 304L stainless steel under opt Imum metallurglcal conditions in the presence of a radlation fleld. Incoloy Alloy 825 would be expected to be more resistant to SCC as a result of its higher nickel content and to localized corrosion as a result of its higher molybdenum content.

The copper base alloys were found to undergo moderate rates of general corrosion under anticlpated repository condltions. While linear extrapolation of the reported corrosion rates est imated unaccedtable metal loss for 300 - 1000 years, corrosion rates decreased with time and thus, it is not clear whether these alloys have adequate resistance to general corrosion for use as a contalner material. 
As is the case for the $\mathrm{Fe}-\mathrm{Cr}-\mathrm{NI}$ alloys, the copper base alloys may experlence locallzed corrosion fallures in the Tuff repository. The copper-base alloys underwent pltting and crevice corrosion in studies in $\mathrm{J}-13$ well water in the presence of a radlation fleld. Evidence of locallzed corrosion was also found in potentlodynamic polarization studles. Thus, for the copper-base alloys, a critlcal issue is whether rates of plt propagation are acceptable for the long-term performance of the waste contalners.

While no SCC of the copper-base alloys was reported in any of the studles performed to date under simulated repository conditions, a number of potentlal cracking agents may be present In the repository, such as ammonla and nitrites. Thus, SCC of copper-base alloys cannot be ruled out.

Microblologlcal Induced corrosion (MIC) of both $\mathrm{Fe}-\mathrm{Cr}-\mathrm{NI}$ alloys and copper-base alloys is a potentlal problem after the thermal perlod when radiation levels are low and temperatures fall below bolling. MIC is a serlous problem in many industrles in surface water, well water, and underground environments. Thus, MIC may play a role in the long-term release rate of the repository. 
The Department of Energy (DOE) is conducting a program for the disposal of high-level radloactive waste in a deep-mined geologlc repository. The Nuclear Regulatory Commission (NRC), which is responslble for regulating high-level radloactlve waste dlsposal, Wlll revlew DOE's appllication for the construction and operat lon of the repository. To assist in evaluating DOE's application, the NRC's Office of Nuclear Regulatory Research is developing an understanding of the long-term performance of the geologlc repository. As part of this effort, Cortest columbus has been awarded a five-year contract to Invest lgate the long-term performance of container materlals used for hlgh-level waste packages. At the direction of NRC, the program is focused on the Tuff repository.

The scope of work conslsts of employing relatively short-term electrochemlcal technlques to examine a wide range of possible fallure modes. Long-term tests (1-4 years) are being used to verlfy the short-term studles. The electrochemlcal techniques being used Include potentlodynamic polarization, potentlostatic polarization, polarization resistance, and electrochemical Impedance spectroscopy. In addition, the susceptlbillty of the candidate container materlals to stress corrosion cracking is being studled ut $/ 1 \mid z$ ing the slow strain rate technique.

This report summarlzes the results of a survey of the IIterature performed under Task 1 of the Cortest program. The purpose of Task 1 is to compile repository site speciflc data that are necessary to develop and update the work plan, to provlde continulty between the Individual tasks of the prolect and to coordinate the project with other NRC projects.

The focus of the survey $1 \mathrm{~s}$, as the name implles, the Influence of environmental varlables on the corrosion behavlor of candldate container materlals for the Turf repository. 


\section{THE TUFF REPOSITORY ENYIRONMENT}

\subsection{Nominal Environment}

There are numerous references in the Ilterature on the compositions of the rock and vadose water expected in the Tuff repository and on other aspects of the geology and hydrology of the repository (Van Konynenburg-1985, Acton-1986, McCrlght-1985, Glassley-1986, Juhas-1984, Oversby-1984C, O'Neal-1983, Russell-1983a, Russell-1983b, McCrlght-1984, McCright-1983, Sass-1982 and Johnstone-1981). To summar Ize these references, the Tuff repository wlll be located in the Topopah Spring Member of the Paintbrush Tuff under Yucca Mountaln, $100 \mathrm{mlles}$ northwest of Las Vegas, Nevada in the Nevada Test SIte (NTS) (Van Konynenburg-1985 and McCrIght-1984). The site is located in an extremely arid zone with about $15 \mathrm{~cm} /$ year annual precipitation ( $0^{\prime} \mathrm{Nea}$ - 1983). The evaporation-transpiration rates also are very hlgh so the net water percolat lng down from the surface is of the order of a few millimeters per year (Sass-1982).

Tuff is an igneous rock of volcanic origin and is composed of volcanlc rock fragments (shards) and ash. The structure of the tuff deposits depends on the cooling rate and degree of compaction after the volcanlc eruption. The rock shards weld together and the compacted material may remain glassy or may devitrify. A layered structure develops - a densely welded core surrounded above and below by zones of materlal decreasing in density and strength. In the post-depositional perlod, alteration of the tuff layers occurs. Crystallization transforms the glassy materlal to feldspar plus quartz or cristoballte. Zeolltization produces hydrous sillcates by reaction of the glassy material with groundwater. A typlcal strat Igraphy of the tuff at the NTS is shown in Figure 2.1 (McCright1984). A more detalled description of these tuff layers is found in Johnstone-1981.

The potentlal repository hor Izon is in the lower, densely welded and devitrifled portion of the Topopah Spring Member 700 to 1400 feet above the statlc water table (Glassley-1986). The bulk rock at the horizon is composed of rhyollte with a small range in composition as shown in Table 2.1 (Schuraytz-1985). This small varlation in geochemistry demonstrates that the host rock may be considered uniform, according to Glassiey-1986.

The vadose water in the repository is thought to be well represented by well water taken from Well $\mathrm{J}-13$. That well is located near the repository slte and produces water whlch has flowed through the Topopah Spring Member, where it lies at a lower elevation and is in the saturated zone, (Juhas-1984). A comparison of the composition of $\mathrm{J}-13$ well water with compositions of vadose waters obtained from tuffs at Ranler Mesa (WhIte-1980, and Henne-1982), whlch is north of Yucca Mountain, shows the unlformlty of the groundwaters; see Table 2.2 (Glassley-1986).

The location of the repository above the static water table has a major impact on the anticipated environment. First of all, the environment will be aerated; the $\mathrm{J}-13$ well water contains $5.7 \mathrm{ppm}$ dissolved oxygen (Mccright-1984), whlch probably represents a lower limit for oxygen. This condition is unlque in that the plans for all other repositories, elther In the United States or elsewhere, have called for locations below the static water table where conditions are deaerated (anoxlc). 


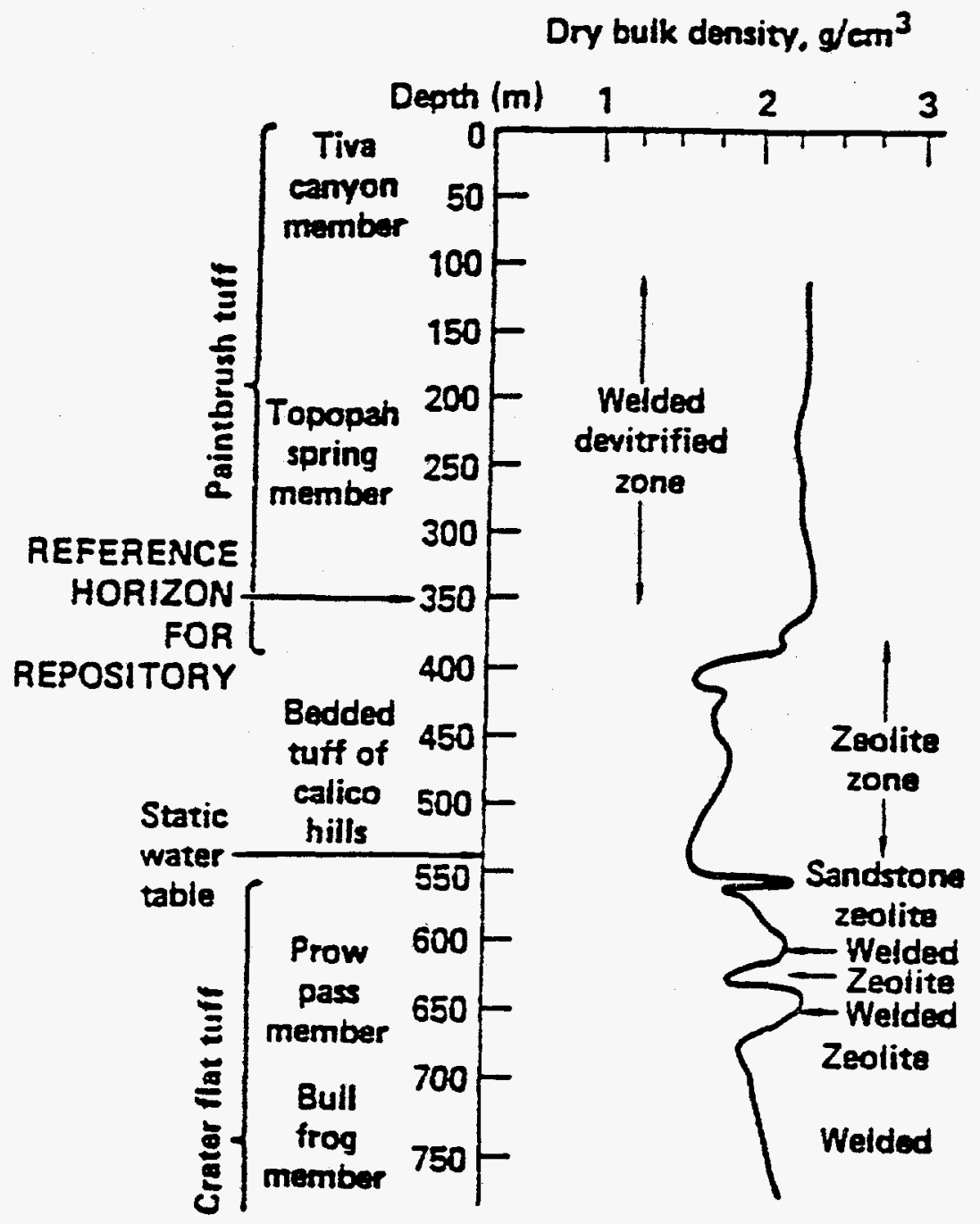

(Drillhole UE 25 a-1)

FIgure 2.1 Representative Stratigraphlc Section In Nevada Tuff (Drillhole UE $25 \mathrm{a}-1$ ). (McCright-1984) 
Table 2.1 Percentages of Major Constltuents In Topopah Spr Ings Tuff, Dr III Core USW GU-3, Samples 60, 61, and 62 .

$\mathrm{Fe}_{2} \mathrm{O}_{3}$ Represents Total Iron. (Schuraytz-1985)

\begin{tabular}{|c|c|c|c|c|c|}
\hline Constituent & 60 & 61 & 62 & Average & Std Dev \\
\hline $\mathrm{SiO}_{2}$ & 78.4 & 78.9 & 78.9 & 78.73 & 0.24 \\
\hline $\mathrm{Al}_{2} \mathrm{O}_{3}$ & 12.0 & 12.3 & 12.2 & 1217 & 0.12 \\
\hline $\mathrm{Fe}_{2} \mathrm{O}_{3}$ & 1.016 & 0.973 & 1.000 & 0.996 & 0.018 \\
\hline $\mathrm{C}_{2} \mathrm{O}$ & 0.492 & 0.451 & 0.480 & 0.474 & 0.017 \\
\hline MgO & 0.1271 & 0.1281 & 0.1126 & 0.123 & 0.007 \\
\hline $\mathrm{TiO}_{2}$ & 0.1108 & 0.0927 & 0.0984 & 0.101 & 0.008 \\
\hline $\mathrm{Na}_{2} \mathrm{O}$ & 4.07 & 3.92 & 4.25 & 4.08 & 0.13 \\
\hline $\mathbf{K}_{\mathbf{2}} \mathrm{O}$ & 3.71 & 3.18 & 294 & 328 & 0.32 \\
\hline $\mathrm{P}_{2} \mathrm{O}_{3}$ & 0.01 & 0.01 & 0.03 & 0.02 & 0.01 \\
\hline $\mathrm{MnO}$ & 0.0624 & 0.0455 & 0.0488 & 0.052 & 0.007 \\
\hline
\end{tabular}


Table 2.2 Average Composition of Interstitlal, Fracture, And Tunnel Water From Unsaturated Zone Of RaInler Mesa Compared WIth Well J-13 Water. (AlI Values Except pH Are In mols/L.) (Glassley-1986)

\begin{tabular}{|c|c|c|c|c|}
\hline & \multicolumn{2}{|c|}{ White et al. (1980) } & \multirow{2}{*}{$\frac{\text { Henne (1982) }}{\text { Tunnel water }}$} & \multirow{2}{*}{$\frac{\text { Ogard and Kerrisk (1984) }}{\text { Well J-13 }}$} \\
\hline & Interstitial & Fracture & & \\
\hline$N_{\mathbf{a}}$ & 1.73 & 1.53 & 2.30 & 1.96 \\
\hline $\mathbf{K}$ & 0.18 & 0.12 & 0.11 & 0.14 \\
\hline $\mathrm{Ca}_{2}$ & 0.27 & 0.21 & 0.08 & 0.29 \\
\hline $\mathbf{M g}_{\mathbf{g}}$ & 0.10 & 0.06 & 0.01 & 0.07 \\
\hline $\mathrm{HCO}_{3}^{-}$ & 1.14 & 1.61 & 2.25 & $2.34^{\star}$ \\
\hline so:- & 0.43 & 0.15 & 0.10 & 0.19 \\
\hline $\mathrm{Cl}^{-}$ & 0.75 & 0.24 & 0.18 & 0.18 \\
\hline $\mathrm{SiO}_{2}$ & 0.97 & 0.88 & 0.73 & 1.07 \\
\hline $\mathrm{pH}$ & 7.8 & 7.5 & 7.0 & 6.9 \\
\hline
\end{tabular}

a Measured alkalinity. 
A second feature of the location of the repository above the water table Is the ellmination of the hydrostatic head on the waste container (McCright1984). At the repository elevation, the bolling point for water is about $95^{\circ} \mathrm{C}$ and thus the environment at the waste package surface $w 111$ be steam and alr during the early life of the repository (Van Konynenburg-1985).

\subsection{Thermal Effects}

The repository is being deslgned for two types of waste packages; spent fuel and processed defense high level waste In the form of borosillcate glass. The spent fuel wlll have the hlghest thermal output of between 1.3 and 3.3Kw per contalner, while the glass will have an output of 0.25 to $0.47 \mathrm{KW}$ per contalner ( $\left.0^{\prime} \mathrm{Nea} /-1984\right)$. The early plans also called for the disposal of processed commerclal high level waste, whlch has the highest heat output of the three types of waste, but currently there are no plans to process this waste. The temperature historles of the waste packages are sensltive functions of the thermal propertles of the near-field rock, the speciflc configuration of boreholes and emplacement drifts, heat transfer mode as well as contalner output power; none of these factors has been preclsely defined (Acton-1986). Comparative canister surface temperatures as a function of time are shown in Figure 2.2 (McCrlght-1984) for one set of condltions. Note that the canister surface for spent fuel remalns above the bolling temperature over at least a 300 year perlod following emplacement. Figure 2.3 (Acton-1986) shows that, for a set of simllar conditions, the thermal effect extends some distance from the waste package.

These elevated temperatures should exclude llquld water from the near fleld of the repository for several hundred years, although llquld water may be present in the pores in the rock up to $140^{\circ} \mathrm{C}$ (Travis-1984). It is also possible that vadose water may come in contact with some of the waste packages during perlods of heavy precipltation.

A consequence of the elevated temperature in the repository will be the interaction of groundwater with the host rock in the vicinity of the waste package. A number of Interaction studies have been performed over temperatures ranging from $90-250^{\circ} \mathrm{C}$ with core wafers, crushed core wafers In gold-bag and Teflon-l Ined autoclaves (Knauss-1985b, Knauss-1985a, Knauss-1984a, Oversby-1984d, Oversby-1984b). As might be expected, the most rapld shlfts in chemlstry occurred with crushed rock as opposed to wafers because of the higher surface area with the former. Changes in solution concentration at $90^{\circ} \mathrm{C}$ were minor; whereas, more pronounced shlfts occurred at $150^{\circ} \mathrm{C}$. Results obtalned by Knauss-1985a for crushed core materlal at $150^{\circ} \mathrm{C}$ are given in Figures 2.4 and 2.5. These data show that the sllicon concentrations increased from about $30 \mathrm{ppm}$ to around 150ppm within 60 days, while the $\mathrm{Na}$ concentration only Increased slightly over the test perlod. The concentrations of $\mathrm{Al}, \mathrm{Mg}$ and $\mathrm{Ca}$ decreased $\mathrm{Wl}$ th $t$ ime while that of $K^{*}$ was not greatly affected by thermal interaction; the $\mathrm{pH}$ decreased very slightly. Anlon analyses for the above tests (dr IIIcore DB-4), performed at the end of the test and other dr III core samples are given in Table 2.3 (Knauss-1985a). These data show that the concentrations of deleterlous specles such as $\mathrm{F}, \mathrm{Cl}$ and $\mathrm{NO}_{3}$ were not greatly affected by interaction with the host rock. The general trends at $250^{\circ} \mathrm{C}$ were similar to those described for $150^{\circ} \mathrm{C}$.

* Both $A l$ and $K$ exhlbited Initilal transient increases in concentrations. 


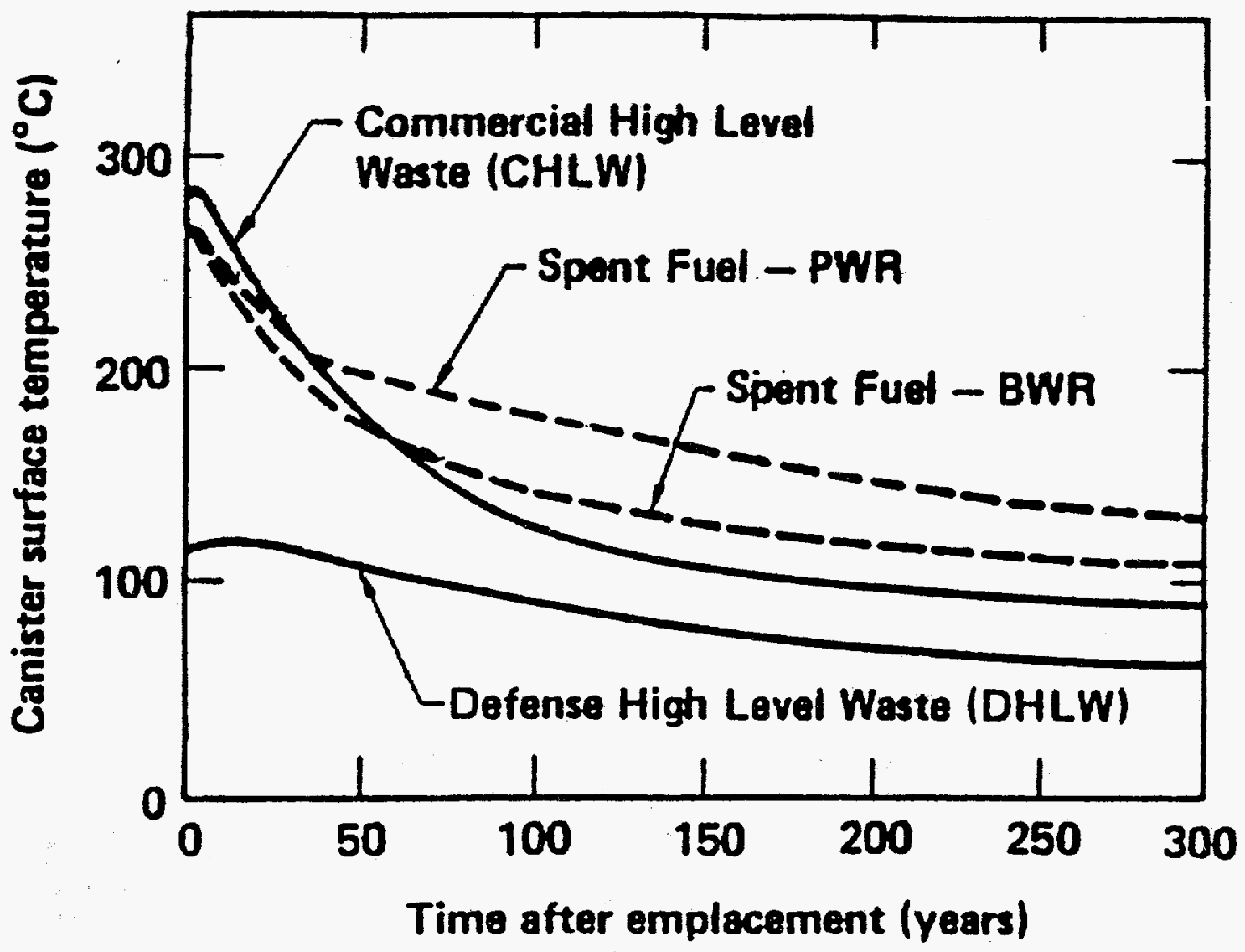

Figure 2.2 Comparative Canister Surface Temperature-Time Profiles For Different Waste Packages In A Tuff Repository (Vertlcal Emplacement, $50 \mathrm{kw} / \mathrm{acre}$ Areal Loading). (McCr Ight-1984) 


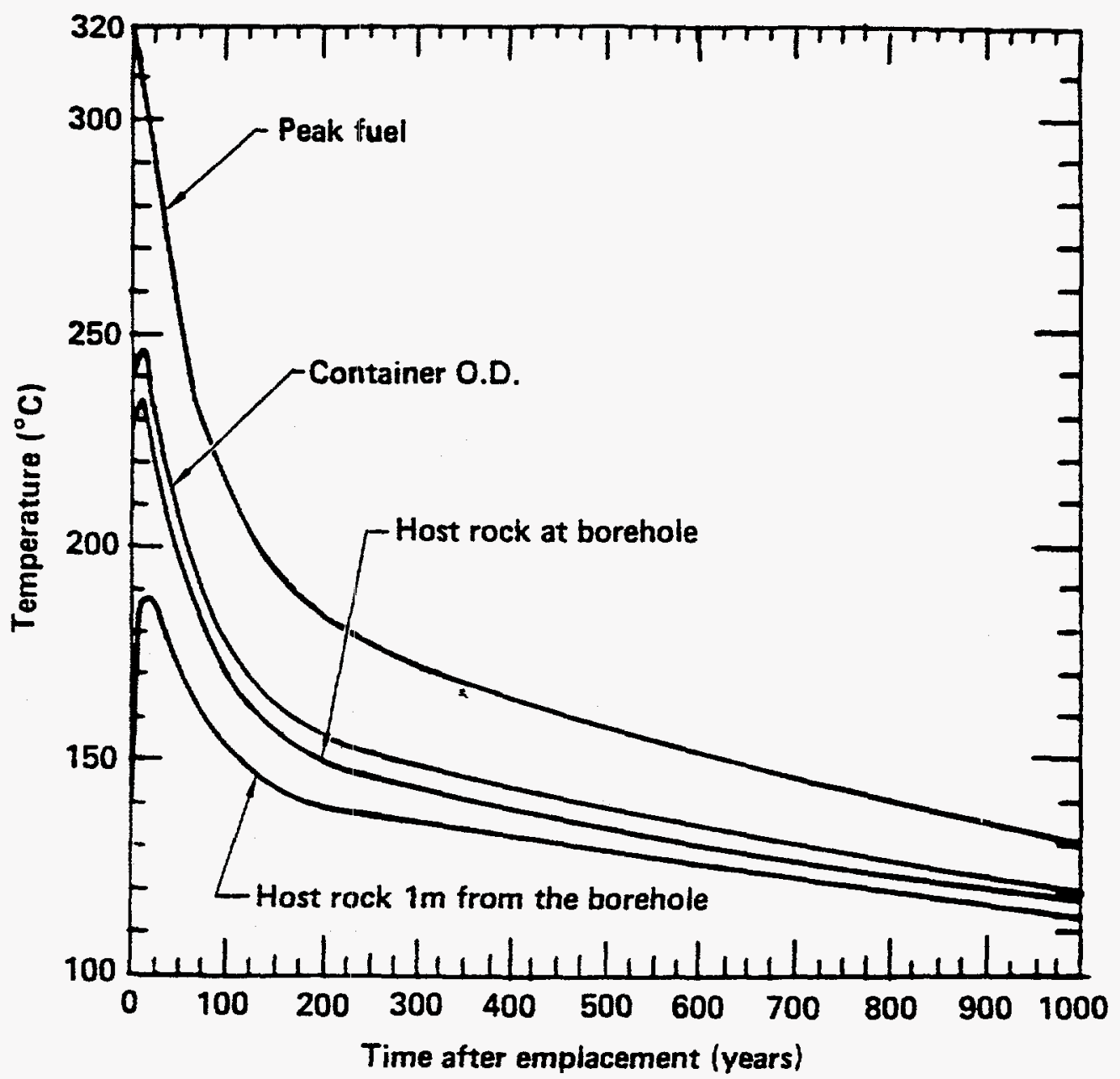

Flgure 2.3 Temperature Historles of A Spent Fuel Waste Package in Tuff. The 70-cm Dlameter Package Contalns 10-Year Aged PWR Fuel with Thermal Power of $3.3 \mathrm{~kW}$, Vertlcally Emplaced In An Array with Areal Power Density of $57 \mathrm{kw} / \mathrm{acre}$. (Acton-1986) 


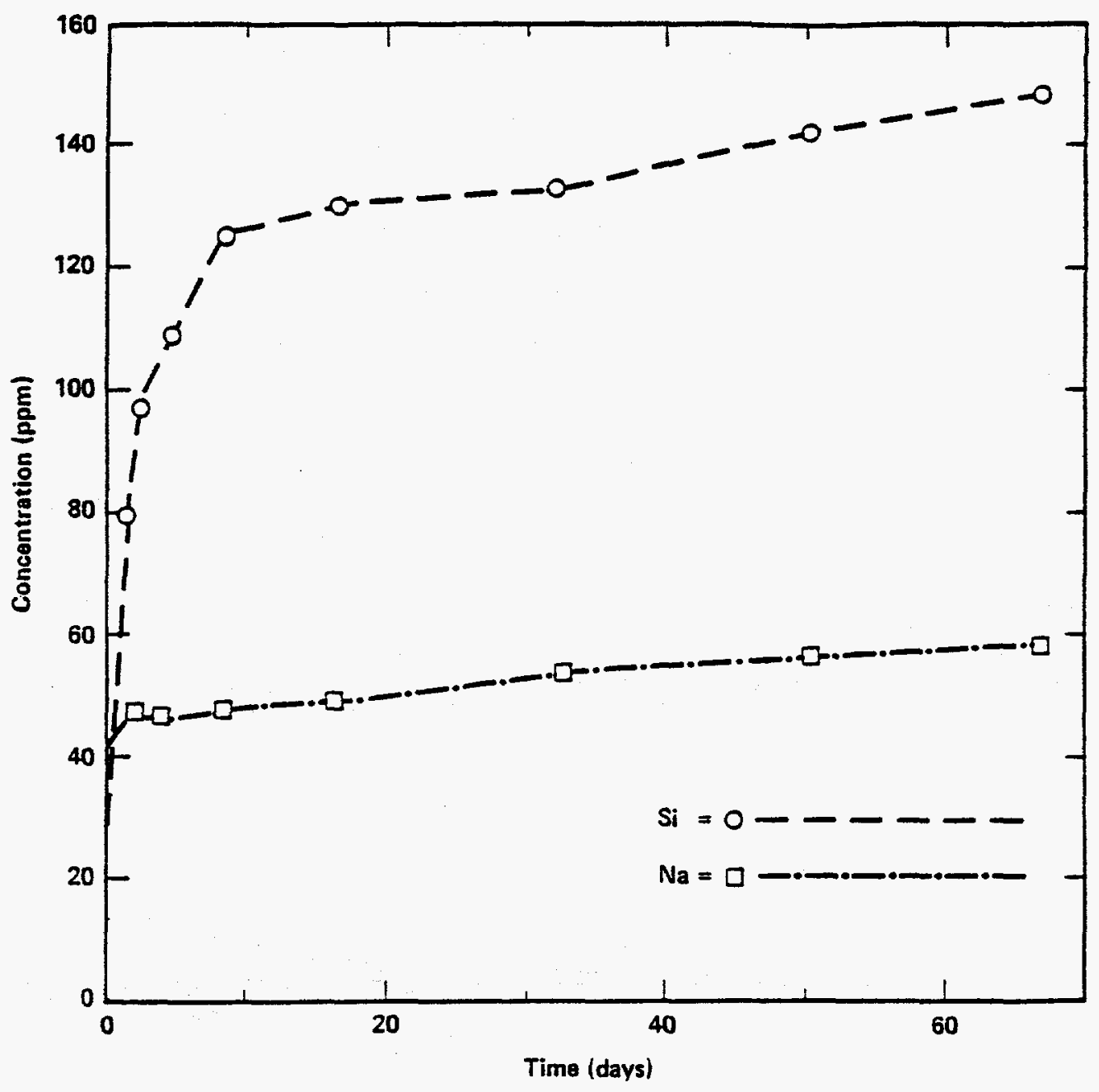

Figure 2.4 silicon And Sodlum Concentratlons In J-13 Water Reacted with Crushed $G-1$ Materlal At $150^{\circ} \mathrm{C}$ As A Function of Time In Days. (Knauss-1985a) 


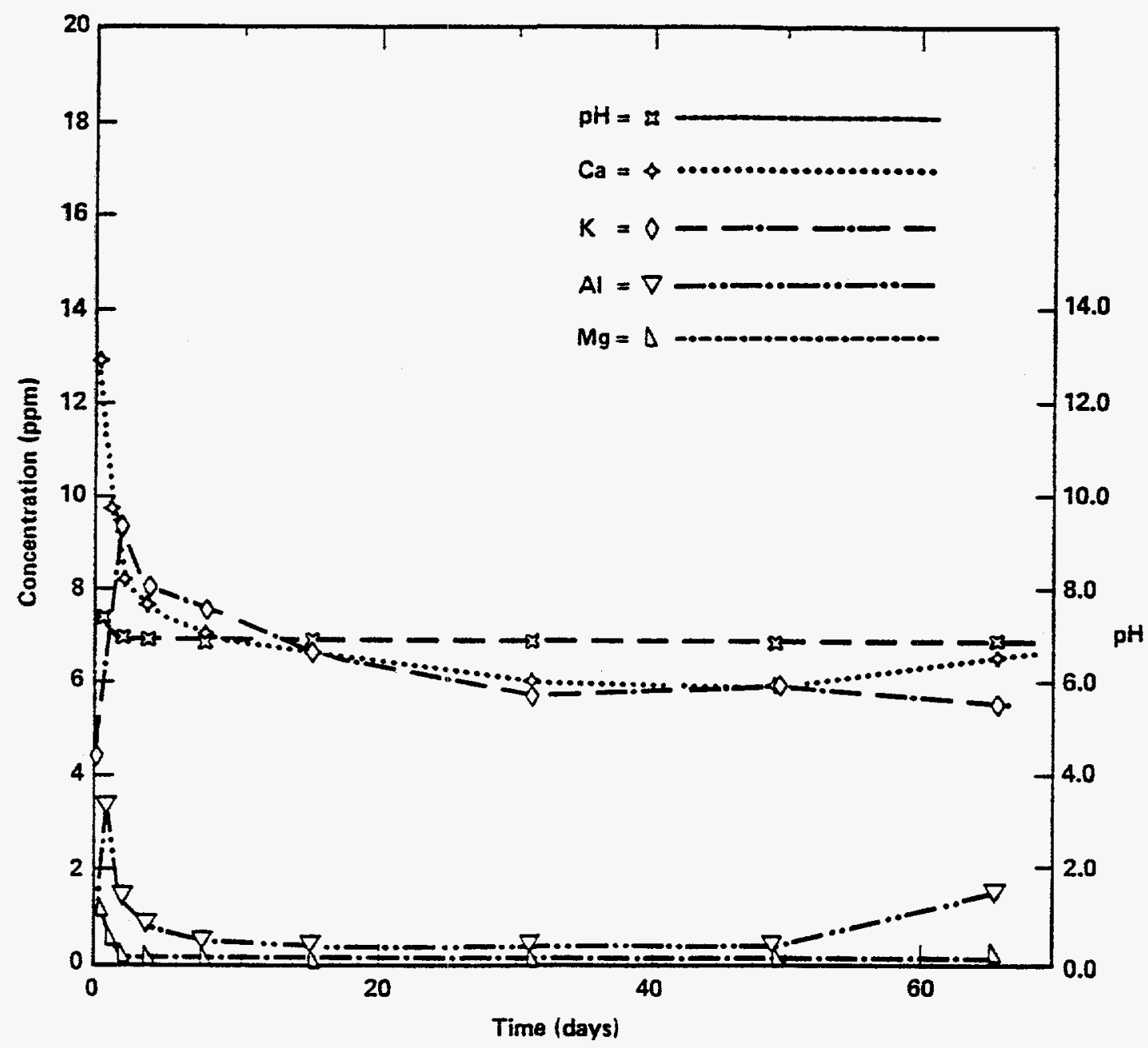

FIgure 2.5 Aluminum, Potasslum, Calclum, Magnesium, and pH Analyses From J-13 Water Reacted With Crushed G-1 Material At $150^{\circ} \mathrm{C}$ As A Function of TIme In Days. (Knauss-1985a) 
Table 2.3 Inductively Coupled Anion Analyses And pH For $150^{\circ} \mathrm{C}$ Exper Iments. (Knauss-1985a)

\begin{tabular}{|c|c|c|c|c|c|c|}
\hline Sample & pH & $\underset{(\mathrm{mmol} / \mathrm{l})}{\mathrm{HOC}_{3}}$ & $\begin{array}{c}\text { F } \\
\text { (ppm) }\end{array}$ & $\underset{\text { (ppm) }}{\text { Cl }}$ & $\begin{array}{c}\mathrm{NO}_{3} \\
\text { (ppm) }\end{array}$ & $\begin{array}{c}\text { SO, } \\
\text { (ppm) }\end{array}$ \\
\hline \multicolumn{7}{|l|}{ Drillcore } \\
\hline DB10-0 & 7.86 & 2.41 & 23 & 6.5 & 9.0 & 17.6 \\
\hline DB10-1 & 7.07 & 1.92 & 26 & 7.6 & 9.8 & 18.6 \\
\hline DB10-2 & 6.98 & 1.77 & 26 & 7.6 & 9.7 & 18.4 \\
\hline DB10-4 & 6.97 & 1.74 & 2.5 & 7.1 & 9.5 & 18.5 \\
\hline D810-8 & 6.85 & 1.69 & 26 & 7.4 & 10.4 & 18.2 \\
\hline DB10-16 & 6.87 & 1.73 & 2.6 & 7.4 & 9.7 & 18.3 \\
\hline DB10-32 & 6.91 & $1.64^{2}$ & $24^{4}$ & $7.1^{2}$ & $16.8^{4}$ & 18.6 \\
\hline DB10-50 & 6.98 & $1.67^{\mathrm{a}}$ & $3.1^{2}$ & $7.5^{2}$ & $16.7^{\circ}$ & $18.8^{4}$ \\
\hline DB10-66 & 6.97 & $1.00^{\mathrm{a}}$ & $24^{2}$ & $7.4^{4}$ & $9.5^{2}$ & $18.5^{\circ}$ \\
\hline \multicolumn{7}{|l|}{ Outcrop } \\
\hline$\overline{\mathrm{DB} 4-0}$ & 7.81 & 2.30 & 2.3 & 6.6 & 9.0 & 18.1 \\
\hline DB4-6 & 7.05 & 2.16 & 24 & 8.0 & 12.5 & 20.2 \\
\hline DB4-16 & 7.14 & 2.20 & 2.5 & 8.0 & 11.8 & 20.6 \\
\hline DB4-33 & 7.20 & $2.63^{b}$ & 24 & 7.9 & 11.1 & 20.0 \\
\hline DB4-48 & 7.20 & 2.22 & 24 & 7.5 & 10.1 & 19.1 \\
\hline DB4-63 & 7.36 & 2.12 & 24 & 7.6 & 10.2 & 193 \\
\hline DB4-82 & 7.45 & $240^{\circ}$ & 25 & 7.8 & 10.5 & 19.7 \\
\hline
\end{tabular}

New analyst = suspect data.

b Problems with $\mathrm{IC} \mathrm{HCO}_{3}$ measurement; values ranged from 146 to 160 resulting in large negative charge balance. 
A few exper Imentally Induced errors were Identifled in the rock-water Interaction studies. It was found that core samples removed from surface outcroppings contalned soluble salts (as a result of surface evaporation) leading to hlgher concentrations of some specles. Such materlals are not likely to be present at the clepth of the repository horizon (Oversby1985). It also was found that tests performed in Tefion IIned autoclaves (PARR Bombs) consistently resulted in lower concentrations of dissolved carbonate specles and hlgher pHs than simliar tests run in gold-bag autoclaves. This behavlor is thought to have resulted from uptake of $\mathrm{CO}_{2}$ by the Teflon Capsules (Knauss-1983). Note that the data discussed above are taken from gold-bag autoclave tests wlth rock taken from deep or III cores.

Another consequence of the ellevated temperatures in the repository will be the bolling of groundwater in the vicinity of the waste package. This will lead to the concentration of the species, both beneficlal and deleter lous in the groundwater. Researchers at Lawrence Livermore Laboratorles have performed IIttle research in this area. On the other hand, Abraham-1986 has performed some solution analyses on bolling $\mathrm{J}-13$ groundwaters at Brookhaven Natlonal Laboratory. In stress corrosion cracking tests performed by Abraham-1986, solution analyses were performed perlodically over a one year perlod. The studles were performed on two solutions; a synthetic J-13 well water and an Inltial 10X concentration of that water. The solutions were bolled in the presence of Tuff rock and specimens of several stainless steels.

Results are summarlzed in Table 2.4, and Flgures 2.6 and 2.7 (Abraham1986). These data show that the composition of J-13 water changed quite dramatically as a result of bolling. The stable concentrations of most specles after one year were more than an order of magnitude higher than those in the $\mathrm{J}-13$ well water. Some specles, such as $\mathrm{SO}_{4}^{-2}, \mathrm{NO}_{3}^{-}, \mathrm{Ca}+2$ and $\mathrm{K}^{+}$exhiblted a maximum in concentration after a few months suggests the precipltation of compounds such as $\mathrm{CaSO}_{4}$, etc.

The concentration of the species in the $10 \times \mathrm{J}-13$ well water also increased with exposure time in these tests. Although the magnitudes of the increases were smaller than those observed for the J-13 well water, the actual final concentrations of the specles in the tests with the $10 \mathrm{X} \mathrm{J-13}$ well water were higher than those in the standard $\mathrm{J}-13$ well water. As in the $J-13$ well water, maximum concentrations were observed for some species in the bolling $10 \mathrm{X} \mathrm{J}-13$ well water after a few months.

\subsection{Radiation Effects}

Relatively little research has been performed on the influence of the radlation fleld on the environment in the Tuff repository. On the other hand, a number of articles discuss, in general terms, the anticlpated role of radiation in altering the repository environment (McCright-1984, Glass-1985, Glass-1986b, Glass-1986a, Yunker-1986b, Yunker-1986a, Acton-1986 and McCright-1983). As descr Ibed by McCrIght-1984, the highest levels of radlation will occur on emplacement and the levels wlll begin to decay. The radiation of interest with regard to container corrosion will be gamma; short range radiation such as alpha and beta wlll be contained within the waste package whlle the expected neutron flux will be too low to affect the host rock or groundwater. According to WIIcox-1981, gamma 
Table 2.4 Chemical Composition of Test Solutions At The End of Corrosion Tests (ug/ml) (Undlluted And Filtered Solution). (Abraham-1986)

\begin{tabular}{|c|c|c|c|c|c|c|c|}
\hline & \multirow{2}{*}{\begin{tabular}{|} 
Reference \\
$\mathrm{J}-13$ \\
Groundwater
\end{tabular}} & \multicolumn{3}{|c|}{ Synthet1c J-13 Water } & \multicolumn{3}{|c|}{ 10-Times. Conc. J-13 Water } \\
\hline & & $\begin{array}{c}\text { 3-Month } \\
\text { Test }\end{array}$ & $\begin{array}{c}\text { 6-Month } \\
\text { Test }\end{array}$ & $\begin{array}{c}\text { 1-Year } \\
\text { Test }\end{array}$ & $\begin{array}{l}\text { 3-Honth } \\
\text { Test }\end{array}$ & $\begin{array}{c}\text { 6-Honth } \\
\text { Test }\end{array}$ & $\begin{array}{c}\text { 1-Year } \\
\text { Test }\end{array}$ \\
\hline $\mathrm{Na}^{+}$ & 45 & H.D.* & 464 & 510 & 867 & 738 & 908 \\
\hline $\mathbf{K}^{+}$ & 4.9 & 238 & 244 & 106 & 244 & 214 & 139 \\
\hline $\mathrm{Ca}^{2+}$ & 14 & 308 & 161 & 104 & 301 & 164 & 129 \\
\hline $\mathrm{Sn}^{2+}$ & H.D. & 3.4 & 0.4 & 1.0 & 4.4 & 0.5 & 1.2 \\
\hline$F$ & 2.2 & 12.1 & 4 & 6.31 & 14 & 5 & 21.1 \\
\hline $\mathrm{Cl}^{-}$ & 7.5 & 130 & 236 & 161 & 330 & 211 & 260 \\
\hline $\mathrm{NO}_{3}{ }^{-}$ & 5.6 & 460 & 750 & 482 & - & 522 & 672 \\
\hline $\mathrm{SO}_{4}{ }^{2-}$ & 22 & 820 & 552 & 588 & 1300 & 1260 & 976 \\
\hline $\mathrm{SLO}_{2}$ & 61 & 414 & 451 & 458 & 408 & 488 & 406 \\
\hline $\begin{array}{l}\text { pH at room } \\
\text { temperature }\end{array}$ & 8.5 & 8.4 & 9.0 & 9.3 & 8.4 & 8.9 & 9.3 \\
\hline
\end{tabular}




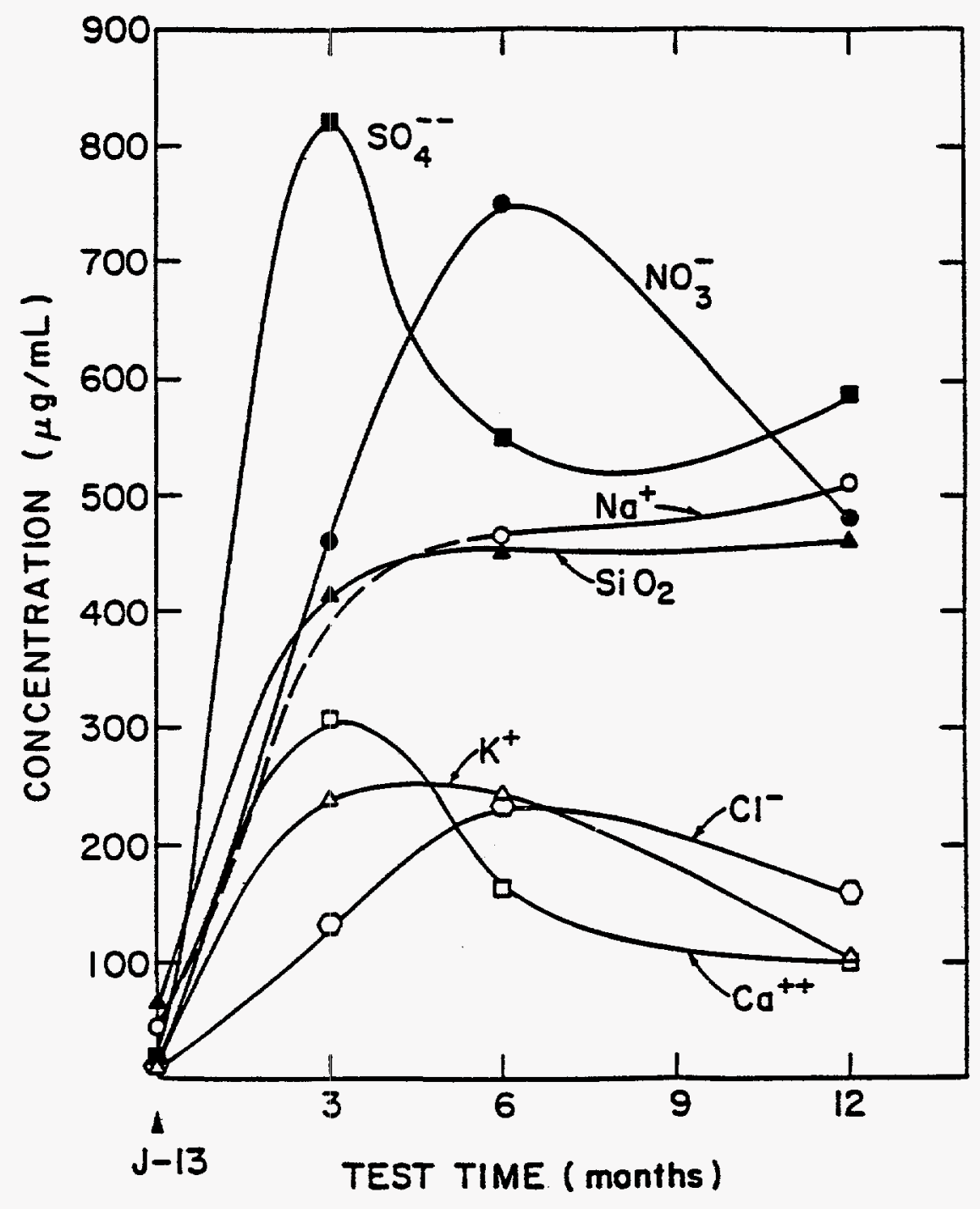

Figure 2.6 Concentration Changes In $\mathrm{J}-13$ Water During React Ion With Crushed Tuff Alt $100^{\circ} \mathrm{C}$. (Abraham-1986) 


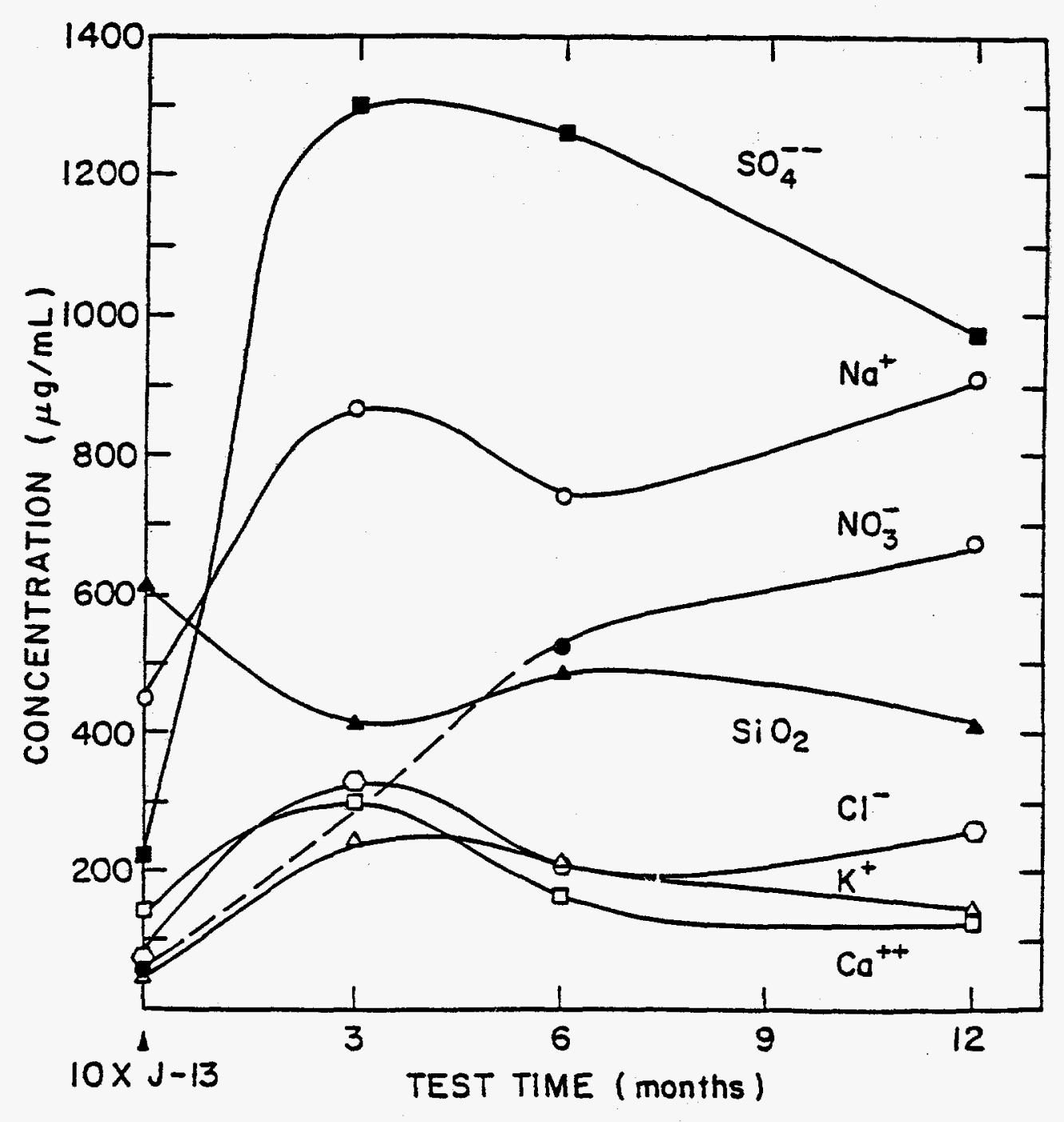

Figure 2.7 Concentration Changes In 10xJ-13 Water During Reaction with Crushed Tuff At $100^{\circ} \mathrm{C}$. (Abraham-1986) 
radiation levels will be four orders of magnltude higher than neutron radiation levels. Interaction of the gamma radiation with ol ther the contalner or the host rock also is expected to be $\mathrm{m}|\mathrm{n}| \mathrm{mal}$ and thus the primary problem is interaction of the gamma radiation field with the llquid and gas phases in the repository. According to Yunker-1986b, the expected Initlal radiation levels lie from $5 \times 10^{3}$ rads/hr for defense high level waste to $2 \times 10^{4} \mathrm{rads} / \mathrm{hr}$ for commerclal spent fuel.

According to McCright-1984, most of the fission products responsible for the gamma radiation decay rapldiy, and thus it is expected that, for commerclal high level waste, the flux level after 100 years wlll be $10 \%$ of that at emplacement. According to Yunker-1986b, the dose rate will have decreased to about $2 \times 10^{2} \mathrm{rads} / \mathrm{hr}$ when the waste package temperature reaches $95^{\circ} \mathrm{C}$; the waste type was not speclfied in this estimate.

Therefore, It appears that during the time period when radlation levels are $h$ Igh, the environment wlll conslst of alr and water vapor.

Radiolysis products expected in the molst air system are not well established according to Van Konynenburg-1986. Some theoretical and experimental research on temperature effects have been performed (Forsythe-1942, Jones-1959, Belttle-1967, and Van Konynenburg-1986). Above $135^{\circ} \mathrm{C}$, the dominant spieles are $\mathrm{NO}, \mathrm{N}_{2} \mathrm{O}$ and $\mathrm{O}_{3}$. Between 120 and $135^{\circ} \mathrm{C}, \mathrm{NO}_{2}, \mathrm{~N}_{2} \mathrm{O}_{4}, \mathrm{H}_{2} \mathrm{O}$ and $\mathrm{O}_{3}$ are the dominant products whlle below $120^{\circ} \mathrm{C}$, the most abundant products are $\mathrm{HNO}_{3}$ and $\mathrm{H}_{2} \mathrm{O}$, with small amounts of $\mathrm{O}_{3}$.

In liquld water at hlgh radlation levels, (>10 $\mathrm{rads} / \mathrm{hr})$, the decomposltion of water will lead to increases in $\mathrm{H}_{2}$ and $\mathrm{O}_{2}$ pressures. Small amounts of nitrates and nitrites also will be produced according to Van Konynenburg-1986. The nitrate to nitrite ratio will depend on the Eh of the solution which in turn is a function of relative concentration of the other specles such as $\mathrm{H}_{2} \mathrm{O}_{2}$, ferrlc lons, etc. The simultaneous presence of llquld water and high radiation flelds are possible only intermittently during perlods of heavy ralnfall.

Glass-1985 and Glass-1986a revlewed the IIterature and performed electrochemlcal studies In Irradlated J-13 well water. They concluded that the primary effect of radiation of $\mathrm{J}-13$ well water is to produce the dominant oxidizing specles $\mathrm{O}_{2}$ and $\mathrm{H}_{2} \mathrm{O}_{2}$ with smaller concentrations of $\mathrm{O}_{2}^{-}$and stIII smaller concentratlons of $\mathrm{HO}_{2} ; \cdot \mathrm{OH}, \mathrm{H}_{2}, \Theta_{2 q}$ - and $\mathrm{H} \cdot$. Glass also stated that irradlation of water containing $\mathrm{CO}_{2}$ or $\mathrm{HCO}_{3}-\mathrm{w} /$ th $\mathrm{O}_{2}$ w/II produce carboxyllc aclds (formlc and oxalic). Glass-1986a measured $\mathrm{H}_{2} \mathrm{O}_{2}$ concentrations of $0.14 \mathrm{mM}$ after 3.5 hours exposure of $\mathrm{J}-13$ well water at $30^{\circ} \mathrm{C}$ and a dose rate of $3.3 \mathrm{MR} / \mathrm{h}$.

Yunker-1986a provided actual laboratory data on environmental effects of radiation in studies of copper base alloys in J-13 well water. Several months exper Iments were performed in autoclaves at $95-150^{\circ} \mathrm{C}$ with a radiation fleld of $-1 \times 10^{5} \mathrm{rads} / \mathrm{hr}$. Gas analyses from alr-water vapor tests at $150^{\circ} \mathrm{C}$ are summarlzed in Table 2.5 (Yunker-1986a). The most striking observation is the dramatle Increase in $\mathrm{CO}_{2}$ In the vapor phase. There was no not lceable increase in gas pressure in this test.

On the other hand, a pressure bulld-up In the autoclave was observed in air-water vapor tests at $95^{\circ} \mathrm{C}$. Figure 2.8 (Yunker-1986a) shows the varlation in pressure in the autoclave. Note that the pressure in the autoclave was relleved perlodically for safety purposes. Results of 
Table 2.5 Gas Composition In Yessel T-2 At $150^{\circ} \mathrm{C}$. (Yunker-1986a)

\section{Gas Composition (vol \%)}

\begin{tabular}{|c|c|c|}
\hline $\begin{array}{c}\text { Breathing } \\
\text { Air } \\
\end{array}$ & $\begin{array}{l}\text { After } 3 \text {-Month } \\
\text { Experiment } \\
\end{array}$ & $\begin{array}{c}\text { After last } 4.5^{\star} \\
\text { Months of } \\
\text { 6-Month Experiment } \\
\end{array}$ \\
\hline $0.95^{\circ}$ & 0.79 & 0.04 \\
\hline 0.05 & 0.53 & 0.06 \\
\hline$<0.7$ & $<0.7$ & $<0.1$ \\
\hline$<0.01$ & $<0.01$ & $<0.01$ \\
\hline$<0.01$ & $<0.01$ & $<0.01$ \\
\hline 78.0 & 80.1 & 80.2 \\
\hline 27.0 & 18.6 & 19.7 \\
\hline$-\infty$ & -. & -- \\
\hline
\end{tabular}

*8 days after previous gas replenishment. 

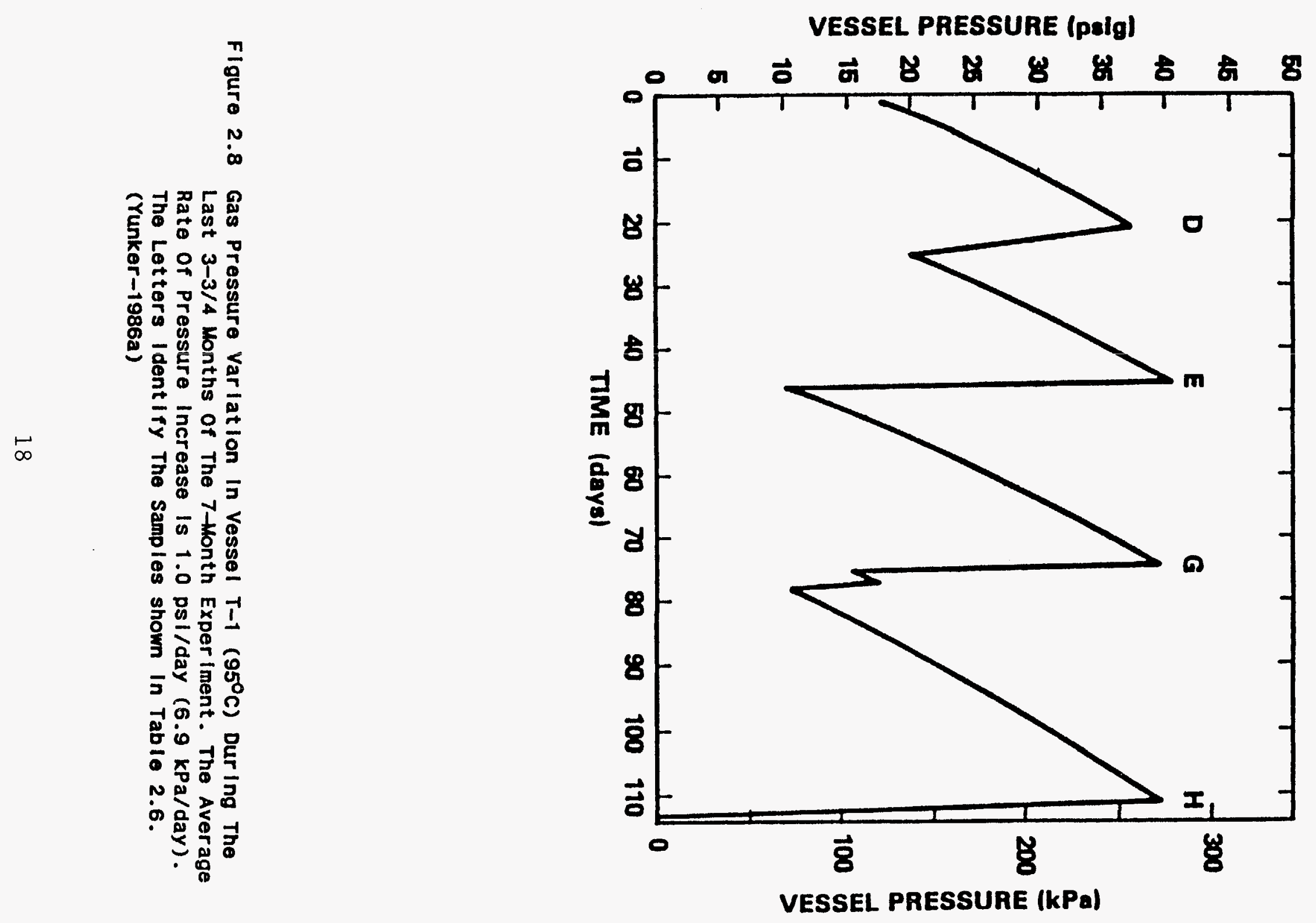
analyses of gas samples taken at those times are given in Table 2.6 (Yunker-1986a). Again note the high observed $\mathrm{CO}_{2}$ pressures in several of the analyses. As expected, a bulld-up of $\mathrm{H}_{2}$ pressure also was noted. No explanation for the $\mathrm{CO}_{2}$ Increases was given in the reference.

Table 2.7 (Yunker-1986a) shows the chemical composition of $\mathrm{J}-13$ well water after exposure in Monel 400 or Titanlum autoclaves at $95^{\circ} \mathrm{C}$ in the presence of the radiation fleld. The data for Monel 400 are suspect since corrosion of the Monel 400 occurred during the test. Note the signlflcant Increase in the concentration of $\mathrm{NO}_{3}{ }^{-}$and $\mathrm{NO}_{2}{ }^{-}$. On the other hand, the concentrations of other aggressive specles, such as $\mathrm{F}^{-}, \mathrm{Cl}^{-}$, and $\mathrm{SO}_{4}{ }^{-2}$ decreased somewhat. The concentration of blcarbonate decreased dramatically from 120 to $9.3 \mathrm{ppm}$. Thls observation is quite significant since b lcarbonate is a passivating agent for many alloy systems. This decrease in solution concentrations may also account for the increase observed in $\mathrm{CO}_{2}$ concentration in the vapor.

While research focussed speclfically on radlation effects in the Tuff repository is $11 \mathrm{mited}$, as described above, research on effects of radlation on water and dilute aqueous solutions is more extensive (Hochanadel-1952, Allen-1961, and SpInks-1961). The primary conclusions from these studies is that a host of translent radicals, lons and stable molecular specles are created by gamma radlation of aqueous solutions. These include: $\mathrm{H} \bullet, \bullet \mathrm{OH}, e^{-} \mathrm{aq}, \mathrm{H}_{3} \mathrm{O}^{+}, \mathrm{OH}^{-}, \mathrm{H}_{2}, \mathrm{H}_{2} \mathrm{O}_{2}, \mathrm{O}_{2}, \mathrm{O}_{2}^{-}$and $\mathrm{HO}_{2}$. Specles such as $e^{-a}$ a, $H_{0}$ and $H_{2}$ can act as reducing agents whlle others such as $\mathrm{H}_{2} \mathrm{O}_{2}, \mathrm{O}_{2}, \mathrm{O}_{2}^{-}$and $\mathrm{HO}_{2}$ can act as oxidlzing agents. The above analysis consider only the breakdown of the water molecule. Many other specles are generated by reaction with other specles in the groundwater (Spinks-1976).

\subsection{Mlcroblological Effects}

Mlcrobes can have a dramatlc Influence on the environment within the repository and, in so doing, promote corrosion fallures of the waste containers. Stoecker -1984 complled a IIst of 37 organisms that have been assoclated with corrosion; see Table 2.8 (stoecker-1984). Pope-1983 discusses the role of many of these organisms in promoting corrosion. By consuming oxygen many organisms create oxygen concentration cells which can lead to crevice corrosion of stainless steels. Similarly, the metabollc production of $\mathrm{CO}_{2}$ creates carbonic acld which also is corrosive. Many of these organisms also produce organlc aclds under blofilms on the metal surface.

Some bacterla such as Gallionella and Sphaerotllus oxidize ferrous and manganous lons resulting in an increase In Eh of the solution and an accumulation of deleterious anlons such as $\mathrm{Cl}^{-}$and $\mathrm{SO}_{4}{ }^{-2}$ to maintain charge neutrallty: ferric and manganic chlorlde are highly corrosive to stalniess steels resulting in severe pltting. Another class of deleter lous microbes is sulfate reducing bacterla (SRBs), such as Desulfovibrlo desulfurlcans. Whlle normally assoclated with anaeroblc conditions, SRBs can coexist with oxygen scavengers that create the requlred conditlons beneath blofilms (Tatnall-1981a). The SRBs then reduce sulfate to produce $\mathrm{H}_{2} \mathrm{~S}$ or $\mathrm{FeS}$, whlch are highly corrosive to many alloys including stainless steels, nickel base alloys and copper base alloys. 
Table 2.6 Gas Composition In Vessel T-1 At $95^{\circ} \mathrm{C}$. (Absolute Atmospheres (KPa)). (Yunker-1986a)

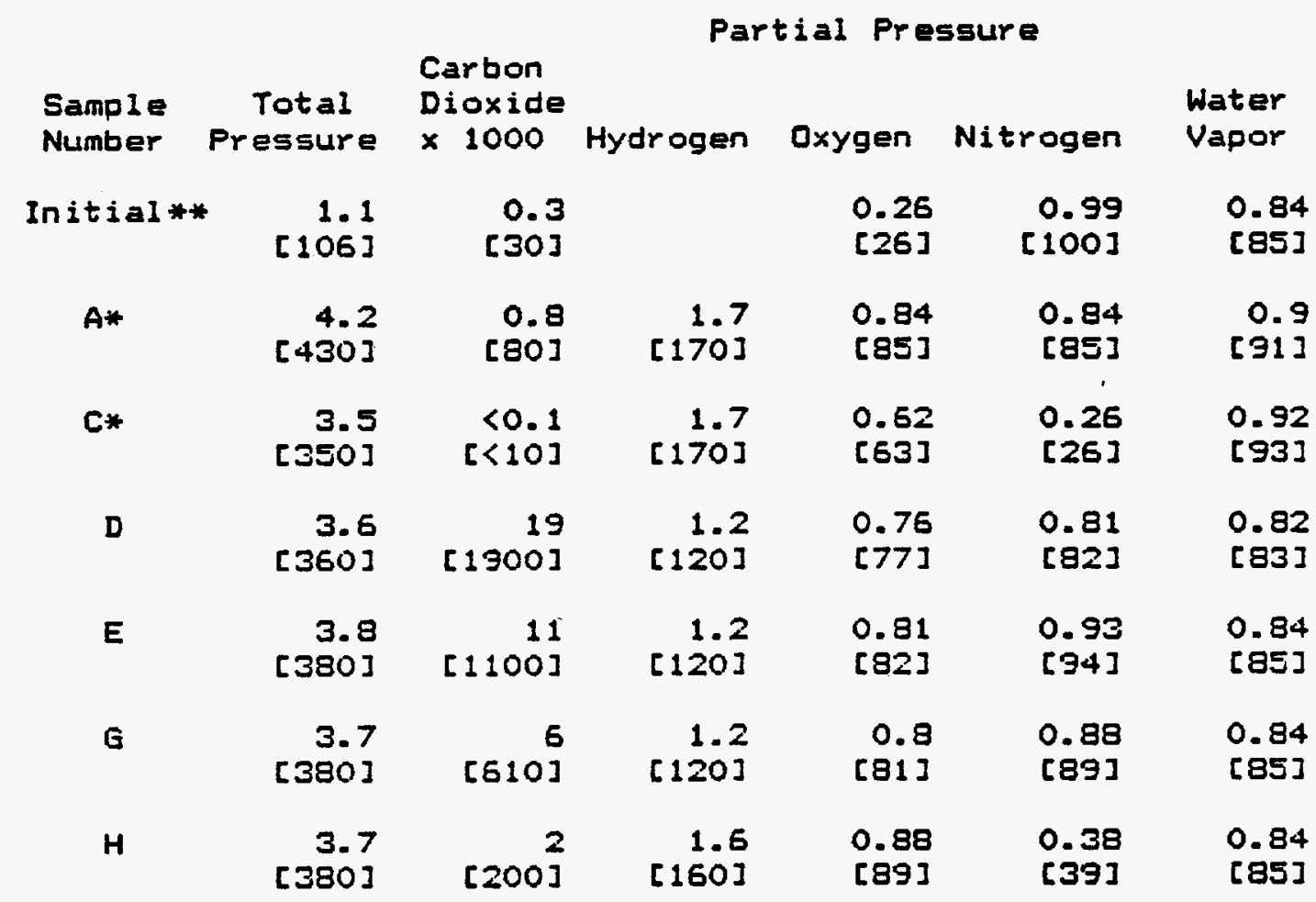

* Samples $A$ and $C$ were taken after one month of exposure and at the end of the 3-month experiment. The contalner materlal was Monel 400. The other samples were taken during the second part of the 7-month experlment. The container materlal was titanlum. (Note: The 7-month exposure perlod was composed of the 3-month experiment followed by a 4-month exposure perlod.)

**Math error in original reference. 
Table 2.7 Water Composition in Vessel T-1 At 95 ${ }^{\circ} \mathrm{C}$. (Yunker-1986a)

Exposure (days)

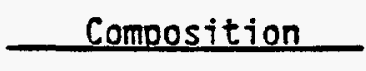

Container Material

pH

$\frac{\text { Species (wopm) }}{F}$

$\mathrm{Cl}$

$\mathrm{NO}_{3}$

$\mathrm{SO}_{4}$

$\mathrm{NO}_{2}$ (est)

$\mathrm{H}_{2} \mathrm{O}_{2}$

Inorganic C

A1

$\mathrm{Ba}$

$\mathrm{Ca}$

$\mathrm{Cu}$

$\mathrm{Fe}$

K

$\mathrm{Li}$

$\mathrm{Mg}$

$\mathrm{Mn}$

$\mathrm{Na}$

$\mathrm{Ni}$

$\mathrm{Pb}$

Si
Sn
Sr

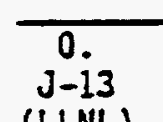

(LLNL)

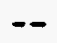

7.1

2.2
7.5

5.6

22.

-.

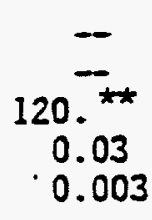

14.

0.0

0.04

4.9

0.05

\section{1}

51.0

$-$

..

$-$

$-$

0.05
2.1
7.0

8.7

19.

-.

23.

23.

$<0.15$

$<0.002$

12.

$<.01$

$<0.02$

6.4

0.07

1.8

$<0.005$

41.

$<0.03$

$<0.10$

30 .

0.15

0.04
1.4

5.8

10.

6.2

3.8

$<1.0$

21.

21.

$<0.15$

0.03

9.8

0.09

$<0.02$

3.3

0.06

1.1

$<0.005$

36.

2.1

$<0.10$

0.54

0.15

0.03
0.38

2.5

2.5

1.8

1.8

$<1.0$

8.4

8.1

$<0.15$

0.04

2.7

$<0.01$

$<0.02$

2.4

$<0.03$

0.06

$<0.005$

17.

0.06

$<0.70$

0.49

$<0.15$

0.01
0.78

3.5

18.8

4.4

1.2

$-7$

9.3

0.18

0.02

3.9

0.03

0.04

4.8

0.13

0.45

$<0.005$

2.8

0.23

$<0.10$

1.45

$<0.15$

0.008

*End of exposure for 7 -month experiment.

** As bicarbonate 
Table 2.8 Compllatlon of Mlcroblologlcal Specles Identifled In Environments Assoclated With Corrosion And Fouling. (Stoecker-1984)

\begin{tabular}{ll}
\hline \multicolumn{1}{c}{ Organism } & \multicolumn{1}{c}{ Organism } \\
\hline Achromobacter Spp. & Micrococcus \\
Aerobacter Spp. & Microspira \\
Aerobacter aerogenes & Nocardia Spp. \\
Alcallgenes & Paracolobactrum Spp. \\
Bacillus Spp. & Proteus Spp. \\
Bacillus cereus & Proteus morganii \\
Bacillus subtilis & Proteus vulgaris \\
Beggiatoa & Pseudomonas Spp. \\
Chromobacterium & Pseudomonas aeruginosa \\
Clostridium Spp. & Pseudomonas oleovorans \\
Crenothrix & Saimonella Spp. \\
Desulfotomaculum Spp. & Sarcina Spp. \\
Desulfotomaculum nigrificans & Shigella Spp. \\
Desulfotomaculum orientis & Sphaerotilus \\
Desulfovibrio Spp. & Spirillum \\
Desulfovibrio africannus & Sporovibrio \\
Desulfovibrio desulfuricans & Staphylococcus Spp. \\
Desulfovibrio salexigens & Slaphyloccccus aibus \\
Desulfovibrio vulgaris & Staphylococcus aureus \\
Diplococcus Spp. & Slaphylococcus citreus \\
Diplococcus pneumoniae & Streptococcus Spp. \\
Escherichia Spp. & Thiobacillus Spp. \\
Esctierichia coti & Thiobacillus concretivorus \\
Escherichia freundii & Thiobacillus thiooxidans \\
Ferrobacillus ferrooxidans & Thiobacillus thioparus \\
Flavobacterium Spp. & Thiothrix \\
Flavobacterium hydrophilium & Vibrio Spp. \\
Gallionella ferruginea & Yeast \\
Klebsiella Spp. & Fungi \\
Klebsiella pneumoniae & Cladsporium resinae \\
Lactobacillus & Cephalosporium Spp. \\
Leptothrix & \\
\hline &
\end{tabular}

Reprinted publ Isher

by permission of the National of Materlals Performance.

\section{Micrococcus}

Proteus Spp.

Proteus morganii

Proteus vulgaris

seudomonas Spp.

Pseudomonas aeruginosa

Pseudomonas oleovorans

Salmoneila Spp.

Sarcina Spp.

Shigella Spp.

Slaphyiococcus Spp.

Slaphyloccccus albus

Slaphylococcus aureus

Slaphylococcus citreus

Streptococcus Spp.

Thiobacillus concretivorus

Thiobacillus thiooxidans

Thobacillus thioparus

Vibrio Spo.

Yeast

Cladsporium resinae

Cephajosporium Spp. 
Sulfur oxldizers such as Thlobaclllus and Ferrobacllius ferrooxldans oxldizo sulfides to sulfates producing sulfurlc acld. They also may oxidize other specles in the groundwater such as ferrous lons to ferrlc lons (Fletcher-1970).

Many types of bacterla, algae and fungl can form bulk slime but the bacterla Pseudomonas is probably the most prevalent in industrlal environments. The slime formers are generally aeroblc and they promote corrosion In two major ways; first of all, by forming a crevice that is deleterlous to many passive alloys such as stainless steels. The slime formers also may harbor other deleterlous specles such as SRBs (Tatnall-1981a).

A summary of the optimum environmental conditions for some of the more common microbes known to cause Mlcroblologlcal Induced Corrosion (MIC) is given in Table 2.9. These data show that the common microbes do not survive at temperatures in excess of $100^{\circ} \mathrm{C}$. Thus, for these mlcrobes, MIC is not Ilkely unt II the repository cools below the bolling point. Of course, a water source presumably would not be present before that $t$ ime anyway. Table 2.9 also shows that $m$ lcrobes responslble for MIC survive over a broad range of $\mathrm{pH}$ and can thrive under low $\mathrm{pH}$ condltions in crevices. Some microbes such as Thlobacllilus also can survive in the presence of polsons such as copper lons. Others, such as SRBs, can survive under aerated conditlons to colonlze deaerated reglons beneath deposits on the surface of the canlster. Thus, after the thermal and radiation perlod in the repository has passed, MIC cannot be ruled out as a contributor to waste container fallures. 
Table 2.9 sumary of Environmental Conditlons For some of The Hore Common Mlerobes.

Ylcrabe

SRBs such as

Desulfovibr to

deaulficans

Sulfur oxldizers

suen as

Thlobacillus and

For robac ll lus

Gallionella

Sphaarotllus

SRES

Range for

all Mlcrobes

Desul fotonaculum

SDD.

Thlobac ll lus

Spp.

Desulfovibr 10

SDD.
Tean. "

떠

Q

Emiroment

Reference

- 5-9.5 anaroble

Ion of

Ion of

5 to 75

$5-9.5$

I-10.5 belom $E_{h}-100$

$\cot \operatorname{lng} 5$

30.80

$\cos \operatorname{inn} 25-30$

$10-60$

$\cot \tan 2-4$ sercole

$>\boldsymbol{a}$

aarcolc

aeroblc

anaeroble

but sirvive

under aeroble

condlttars

to 400 (SHE)

$(-100 \mathrm{~m} /$ ) SHE

ancobic

aerated water and solis

coexisting nith $\mathrm{O}_{2}$ seavengers

Tatral1-1981a

Postgate-1979

Tatra|1-1981a

assoclated with high $\mathrm{Fe}$, in

I. CI deposits

high Fa, in

sediwents, brackish and

salt vater, ofl and gas

mills

Tatnal1-1981a

Tatrall-1981a

Popo-1983

Pastgato-1979

Hertert-i971

uccouga I-1958

Stoocker-1984

Stcecker-1984

anaeroblc otimen 7.2

5.5 to 9

Stocker-1984 


\section{CORROSION BEHAVIOR IN J-13 WELL WATER}

\section{$3.1 \mathrm{Fe}-\mathrm{Cr}-\mathrm{NI}$ Al loys}

\subsubsection{General Corrosion}

The stalnless steels exhlblt excellent resistance to general corrosion In $\mathrm{J}-13$ well water and in saturated steam at $100^{\circ} \mathrm{C}$. Results of 1000 hour tests by McCrIght-1984 on several Iron base alloys are given in Table 3.1 (McCright-1984). In these tests, all specimens were exposed in a single test vessel. These data show that the austenltic stalnless steels exhlbited rates of less than $1 \mathrm{um} / \mathrm{yr}$ under all test condltions. This value extrapolates to a thickness loss of less than $1 \mathrm{~mm}$ in 1000 years exposure In a Tuff repository. The actual thickness loss from general corrosion could be considerably less, based on these data, since general corrosion rates of passive materlals usually decrease with time of exposure.

In these studles, the carbon and low alloy steels also exhlblted moderate rates of general corrosion Indlcating that the bolling assoclated with the elevated temperatures of these tests probably deaerated the solutions. On the other hand, deaerated conditions are generally more aggressive for general corrosion of stalnless steels since oxygen tends to act as a passivating agent. It was speculated in the report that the corrosion products from the carbon and low alloy steel specimens also may have Influenced the corrosion rates for the stainless steels (McCright-1984), although the direction of the effect (beneficlal or detrimental) was not discussed. The presence of the low alloy steels actually simulates conditions where the bore-hole Ilner is fabrlcated of such a materlal. In any case, it could be speculated that the corrosion products could be detrimental to general corrosion of the stainless steols since they would tend to deaerate the environment, making it more reducing.

Results of electrochemical studies performed on the stainless steels in J-13 well water are generally consistent with the weight loss data, although the electrochemistry predlcts somewhat high rates of attack. Figure 3.1 (McCright-1984) shows that corrosion rates based on two electrochemical measurement techniques (polarlzation resistance and Tafel extrapolation) decreased with time and were generally less than about 5 um/yr after 500 hours of exposure. It is interesting to note that Alloy 825 specimens consistent exhiblted higher rates of attack than did austenitic stalniess steels in the electrochemical tests, al though rates for all materlals were moderate. Alloy 825 was not evaluated in the welght loss studles, but is generally considered to be more corrosion resistant that the stainless steels.

Juhas-1984 reported on the Influence of a sensitizing heat treatment on general corrosion behavior. Specimens of 304L stalnless steel were sensitized for one hour at $650^{\circ} \mathrm{C}$ and then exposed to J-13 water, with and without crushed Tuff rock, at $28^{\circ} \mathrm{C}$ for 8760 hours (one year). Results summarized in Table 3.2 (Juhas-1984) show that corrosion rates were low and that sensitization did not influence the results. It was noted by the authors that the degree of sensitization In the specimens was not extensive. 


\section{Table 3.1 Corrosion Test Results For Different Steel Coupons Exposed To $100^{\circ} \mathrm{C}$ Tuff-Condltloned Water And Steam 1000-hour Exposure of TrIplicate Coupons. (McCrlght-1984)}

\begin{tabular}{|c|c|c|c|c|}
\hline \multirow{3}{*}{$\begin{array}{c}\text { Material } \\
\text { Clozo } \\
\text { carbon steel }\end{array}$} & \multicolumn{2}{|c|}{ 1000C Saturated Stean Atmosolineric Pressure } & \multicolumn{2}{|c|}{$\begin{array}{c}1000 \mathrm{C} \mathrm{J}-13 \text { Water Condit loned with } \\
\text { Crushed Tuff Rock }\end{array}$} \\
\hline & $\begin{array}{l}\text { Corrosion Races } \\
\text { (um/yr) }\end{array}$ & $\begin{array}{l}\text { Surface Condition } \\
\text { after Exoosure }\end{array}$ & $\begin{array}{l}\text { Corrosion Rates } \\
\text { (um/yr) }\end{array}$ & $\begin{array}{l}\text { Surface Condition } \\
\text { after Exoosure }\end{array}$ \\
\hline & $\begin{array}{l}43.43 ; \text { वा.66; } \\
60.20\end{array}$ & $\begin{array}{l}\text { Attack in a } \\
\text { crevices" } 0 \text { locallized } \\
\text { attack elsewhere }\end{array}$ & $\begin{array}{l}23.37 ; 29.97: \\
31.73\end{array}$ & $\begin{array}{l}\text { Atack in all } 12 \text { erevices: } \\
\text { some light localized attack } \\
\text { elsewhere }\end{array}$ \\
\hline $\begin{array}{l}\text { A36 } \\
\text { carbon steel }\end{array}$ & $\begin{array}{l}42.67 ; 46.48 ; \\
58.42\end{array}$ & $\begin{array}{l}\text { Attack in } 5 \text { crevices: much } \\
\text { localized attack elsewhere }\end{array}$ & $\begin{array}{l}\text { in } 32.77 ; 39.35 ; \\
\text { e } 36.83\end{array}$ & $\begin{array}{l}\text { Attacx in } 9 \text { creyices; some } \\
\text { localized attack el sewnere }\end{array}$ \\
\hline $\begin{array}{l}\text { A366 } \\
\text { Carbon steel }\end{array}$ & $\begin{array}{l}40.39 ; 52.07 ; \\
62.74\end{array}$ & $\begin{array}{l}\text { Light attacx in } 7 \text { erevices } \\
\text { much localized attack } \\
\text { elsewhere }\end{array}$ & $\begin{array}{l}5: 25.65 ; 30.73 ; \\
27.94\end{array}$ & $\begin{array}{l}\text { Attack in all } 12 \text { erevices: } \\
\text { rery light localized attacx } \\
\text { elsewhere }\end{array}$ \\
\hline $\begin{array}{l}2.25 \mathrm{Cr}-1 \mathrm{Mo} \\
\text { alloy steel }\end{array}$ & $\begin{array}{l}7.87 ; 12.45 ; \\
15.49\end{array}$ & $\begin{array}{l}\text { Attack in } 7 \text { creyices; some } \\
\text { localized attacx elsewhere }\end{array}$ & $\begin{array}{l}\text { le } 29.21 ; 29.97 \\
=31.75\end{array}$ & $\begin{array}{l}\text { Attack in all } 12 \text { ereyices: } \\
\text { considerable locallized attack } \\
\text { elsewhere }\end{array}$ \\
\hline $\begin{array}{l}9 \mathrm{Cr}-1 \mathrm{Mo} \\
\text { alloy steel }\end{array}$ & $1.52: 1.78 ; 1.02$ & $\begin{array}{l}\text { No evidence of crevice or } \\
\text { other localized attack }\end{array}$ & $4.06 ; 3.05 ; 3.30$ & $\begin{array}{l}\text { No evidence of crevice or } \\
\text { other locallized attack }\end{array}$ \\
\hline $\begin{array}{l}409 \text { stainless } \\
\text { steel }\end{array}$ & $n+1 *: n i l ; n i l$ & $\begin{array}{l}\text { No evidence of crevice or } \\
\text { other localized attack }\end{array}$ & n11; nil; nil & $\begin{array}{l}\text { No evidence of creyice or } \\
\text { other localtzed attacx }\end{array}$ \\
\hline $\begin{array}{l}416 \text { stainiess } \\
\text { steel }\end{array}$ & $n+1 ; 0.25 ; 0.25$ & $\begin{array}{l}\text { No evidence of crevice or } \\
\text { other locallzed attack }\end{array}$ & $0.25 ; 0.25 ; 0.25$ & $\begin{array}{l}\text { No eyidence of creyice or } \\
\text { other localized attack }\end{array}$ \\
\hline $\begin{array}{l}304 L \text { stainless } \\
\text { steel }\end{array}$ & $n i l: 0.25: n i l$ & $\begin{array}{l}\text { No eyidence of creyice or } \\
\text { other localized attack }\end{array}$ & nil: $0.25 ; n i 1$ & $\begin{array}{l}\text { No eyidence of creyice or } \\
\text { other localized attack }\end{array}$ \\
\hline $\begin{array}{l}316 \mathrm{~L} \text { stainless } \\
\text { steel }\end{array}$ & nil: nil; nil & $\begin{array}{l}\text { No evidence of crevice or } \\
\text { other localized attack }\end{array}$ & $0.51 ; 0.51 ; 0.51$ & $\begin{array}{l}\text { No exidence of crevice or } \\
\text { other localized attack }\end{array}$ \\
\hline $\begin{array}{c}317 \text { stainless } \\
\text { steel }\end{array}$ & $0.25: n+1 ; 0.13$ & $\begin{array}{l}\text { No eyidence of creyice or } \\
\text { other locallized attack }\end{array}$ & $0.25 ; 0.51: 0.76$ & $\begin{array}{l}\text { No evidence- of ereytee or } \\
\text { other localized attack }\end{array}$ \\
\hline
\end{tabular}




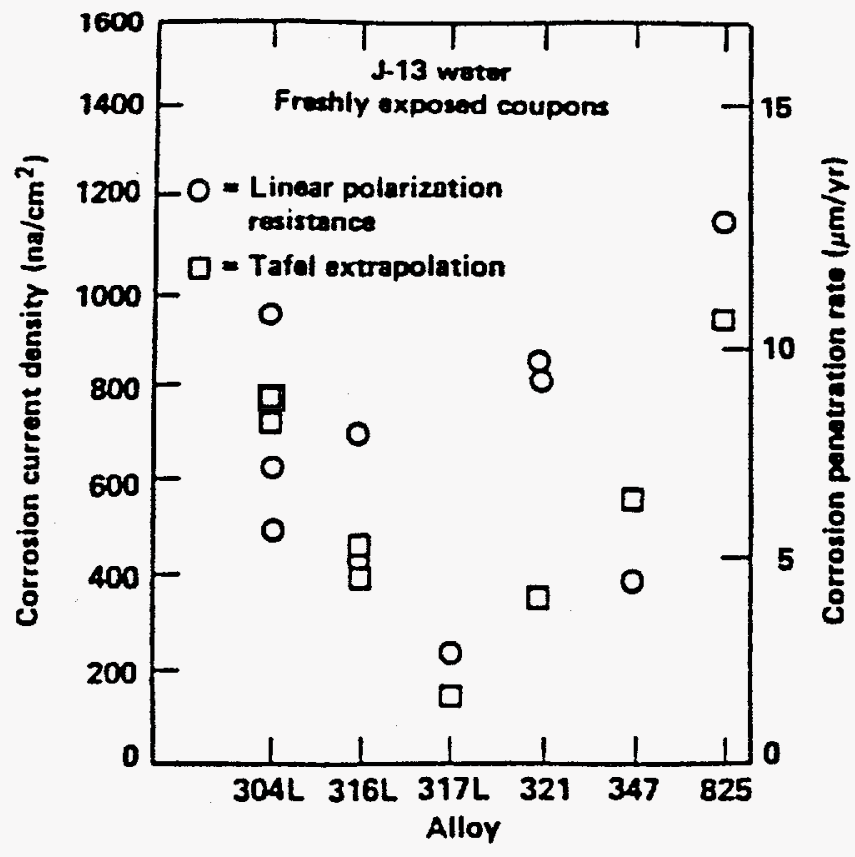

(a) Freshly Exposed Coupons.

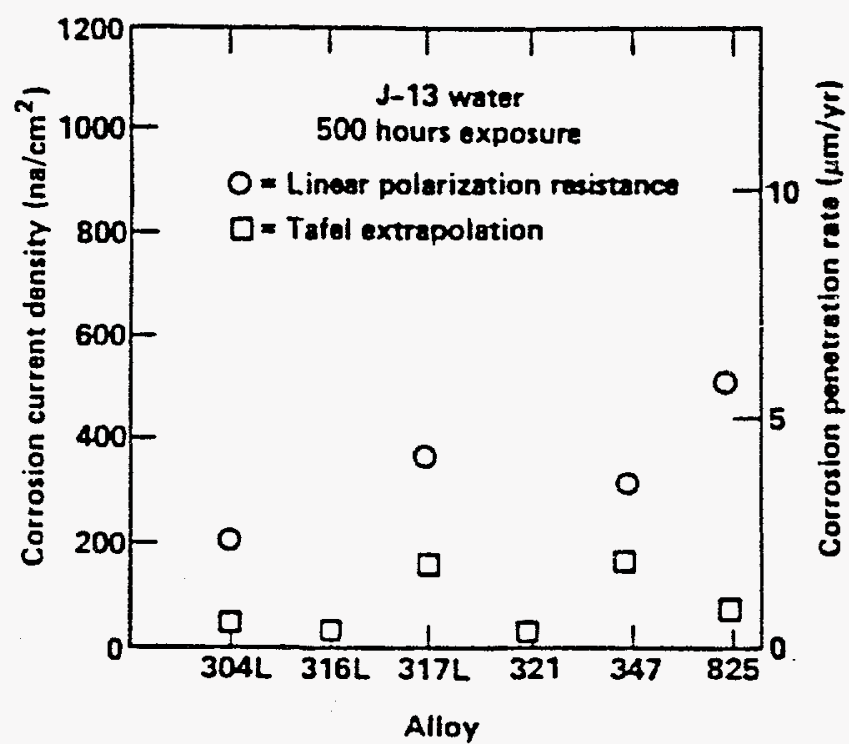

(b) Coupons Provlously Exposed To This Environment For 500 Hours.

Figuro 3.1 Electrochemlcal Doterminatlons of Corrosion Rates For Different Alloys in Tuff-Condlt loned J-13 Water At $100^{\circ} \mathrm{C}$. (MCCrlght-1984) 
Table 3.2 Corrosion Test Results For Roon Temperature Irradlated And Non-Irradlated 304L. Coupons ( 8760 Hrs Exposure). (Juhas-1984)

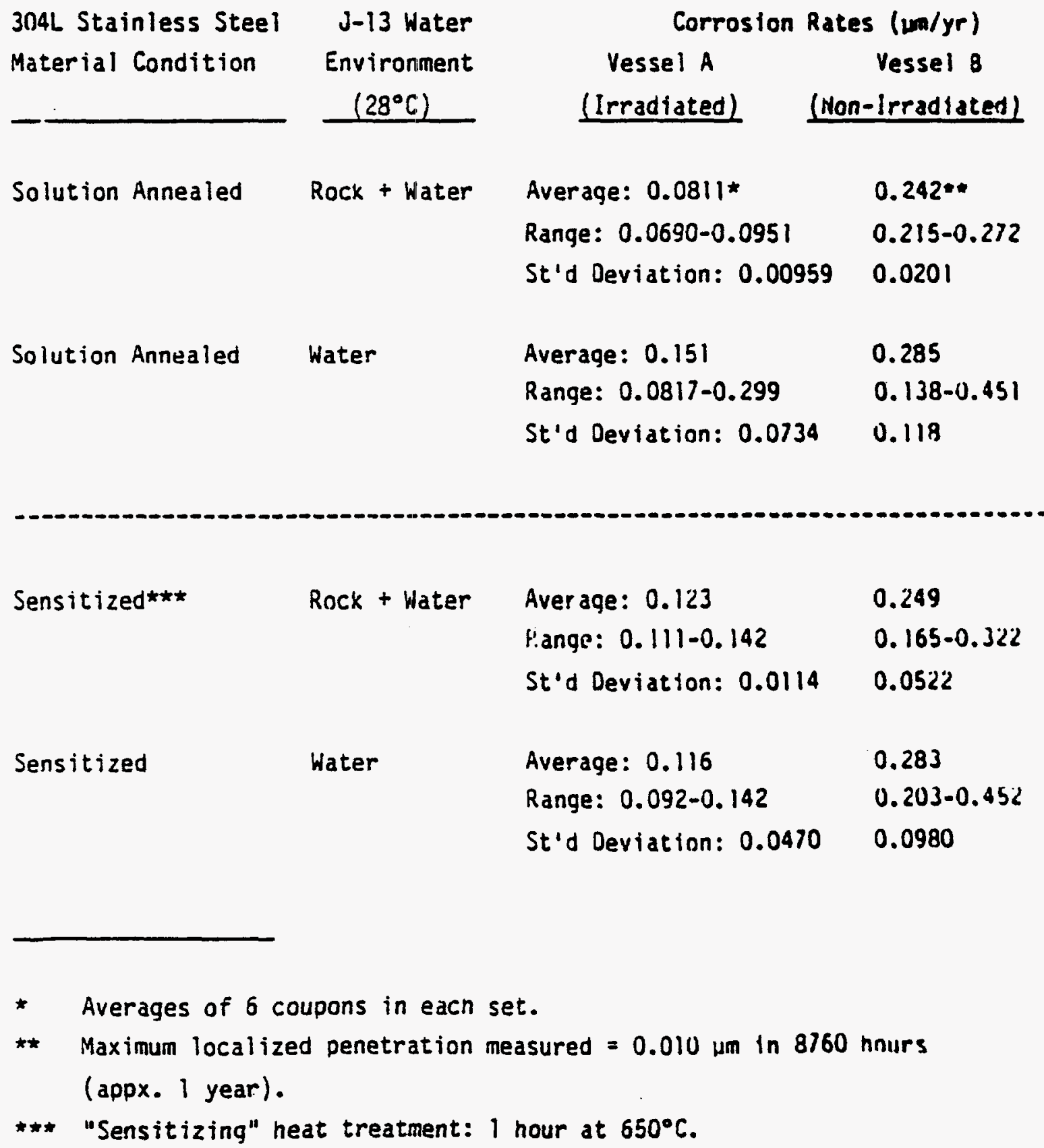




\section{1 .2 Locallzed Corrosion}

In this section, pltting and crevice corrosion of $\mathrm{Fe}-\mathrm{Cr}-\mathrm{NI}$ Alloys are discussed. Stress Corrosion Cracking is addressed in sect Ion 3.1.3.

Glass-1984 and McCright-1984 reported on the results of electrochemical pltting studles of the candidate alloys in $\mathrm{J}-13$ well water. Cyclic anodic polarization curves were obtained on $304 \mathrm{~L}$ stainless steel, 316L stainless steel, and Incoloy Alloy 825 in $\mathrm{J}-13$ water at $50-100^{\circ} \mathrm{C}$. The experiments were performed at a scan rate of $1 \mathrm{mV} / \mathrm{sec}$ under naturally aerated conditlons; no attempt was made to deaerate the $J-13$ water but the water was not sparged with alr. A typlcal polarization curve is shown in Figure 3.2 (GIass-1984) with the pltting related corrosion parameters $E_{p r o t,} E_{p i t}$ and Ecor Identifled. A summary of the results for the four alloys evaluated is given in Figures 3.3-3.5 (Glass-1984). These data show that Eprot values are more noble than $E_{\text {cor }}$ values by several hundred millivolts, indlcating that pltting corrosion is relatively unlikely. The close proximlty of Eprot and $E_{p l t}$ Indlcates that plts that do form passivate readily. No systematic effect of alloy composition on these parameters is evldent from the data.

Crevice corrosion tests of one year duration also were performed on the candldate alloys in $\mathrm{J}-13$ well water at temperatures ranging from 50 to $100^{\circ} \mathrm{C}$ (Glass-1984). The crevices were formed by sandw/ching flat metal specimens between ribbed Teflon washers. All of the alloys examined, Including Alloy 825, showed some preferentlal attack in the crevices after one year of exposure, although the attack was mInor having been described as stalning. However, this stalning is an indlcation that the protective passive films on the stainless steels are breaking down within the crevices. This behavior also demonstrates the difflculty of using the short term electrochemical results to predlct long term behavior.

Sensitization is the precipltation of a chromlum rich carblde phase in the grain boundary of susceptible stalnless steels. The resulting chromlum depleted area has increased susceptlbility to localized corrosion. The process occurs as a result of elevated temperature exposure during welding, heat treatments or In service. For the waste containers, a process known as low temperature sensitization is of great concern. In thls process, carbides nucleated during welding grow as a result of exposure in the repository. Regardless of the mechanism of formation, the chromlum carbldes and the assoclated chromium depleted areas increase the materlals susceptiblilty to localized forms of corrosion such as Intergranular attack and stress corrosion cracking (see section 3.1.3).

Sensitization also can Increase suscept|b|lity to pitting and crevice corrosion. Data on this toplc were not found in the literature for the candldate container materlals in J-13 well water. However, Stefec-1979 reported reduced pitting resistance for a sensitized $17 \mathrm{Cr}-12 \mathrm{NI}-2.5 \mathrm{MO}$ stainless steel, whIch is similar in composition to Type 316, in $0.1 \mathrm{M}$ $\mathrm{NaCl}$. This conclusion was based on results of potentlodynamic polar Ization experiments performed on specimens of the alloy following heat treatment for 1 to 100 hours at 550 to $750^{\circ} \mathrm{C}$. 


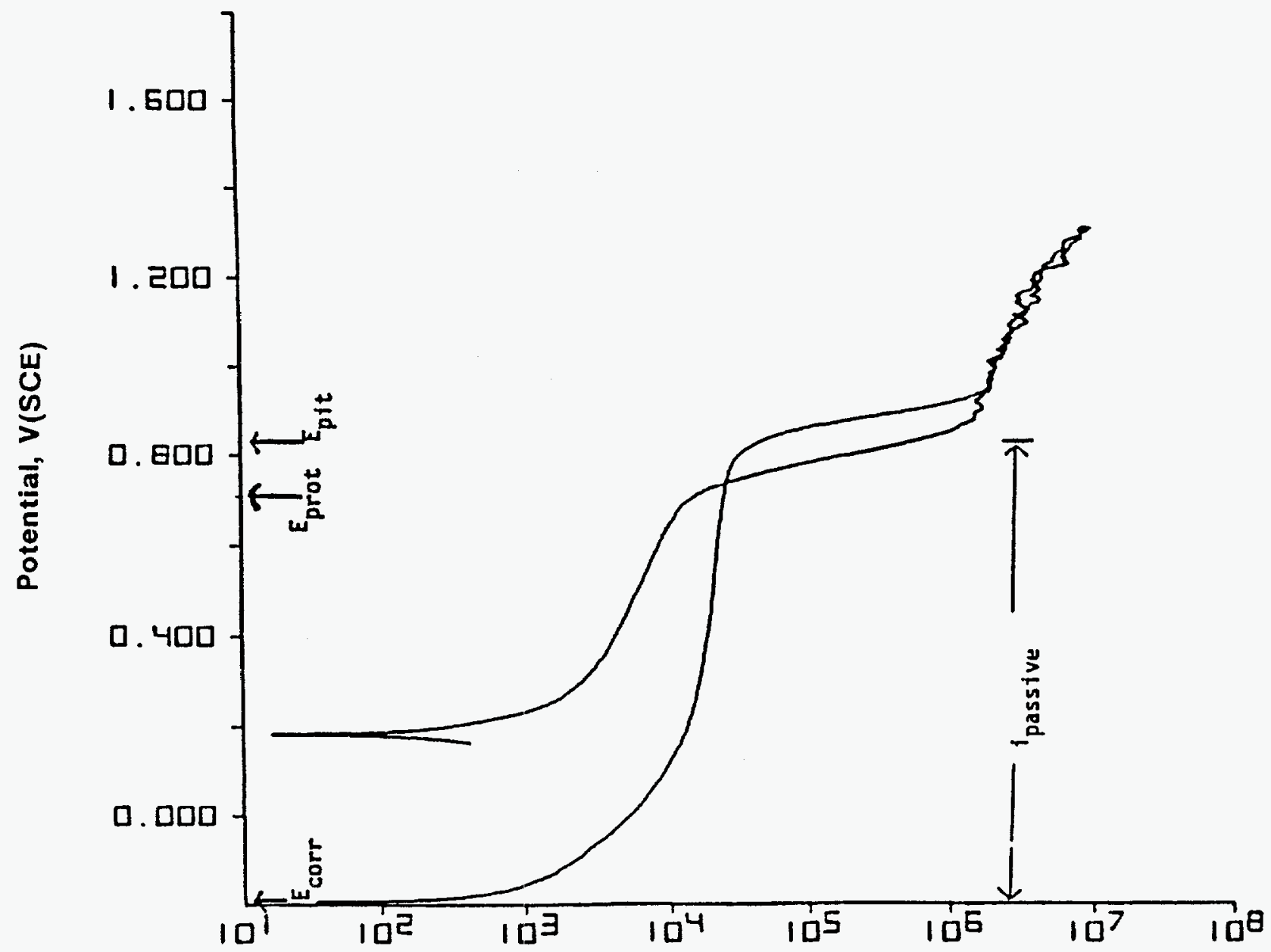

Current Density, nA/cm2

Figure 3.2 Potentlodynamlc Anodlc Polarlzat lon Curve For 304L In $\mathrm{J}-13$ Well Water At $90^{\circ} \mathrm{C}$. Scan Rate Was $1 \mathrm{mV} / \mathrm{s}$. Scan starts From Ecor. (Glass-1984) 


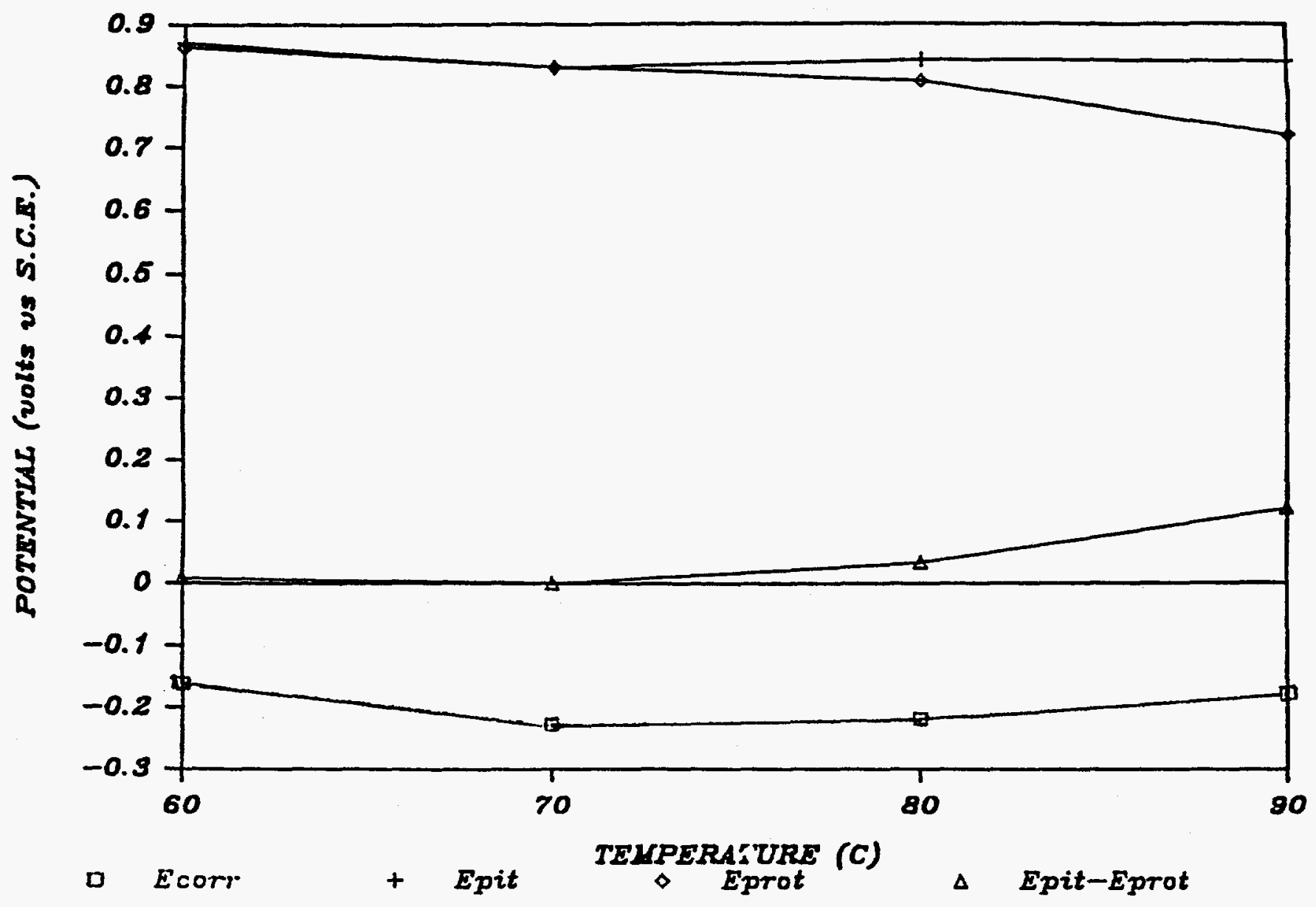

Figure 3.3 Electrochemlcal Parameters For 304L In Tuff-Condltioned J-13 Well Water As A Function of Temperature. All Potentlals Are Referenced To An S.C.E. At $25^{\circ} \mathrm{C}$. (Glass-1984) 


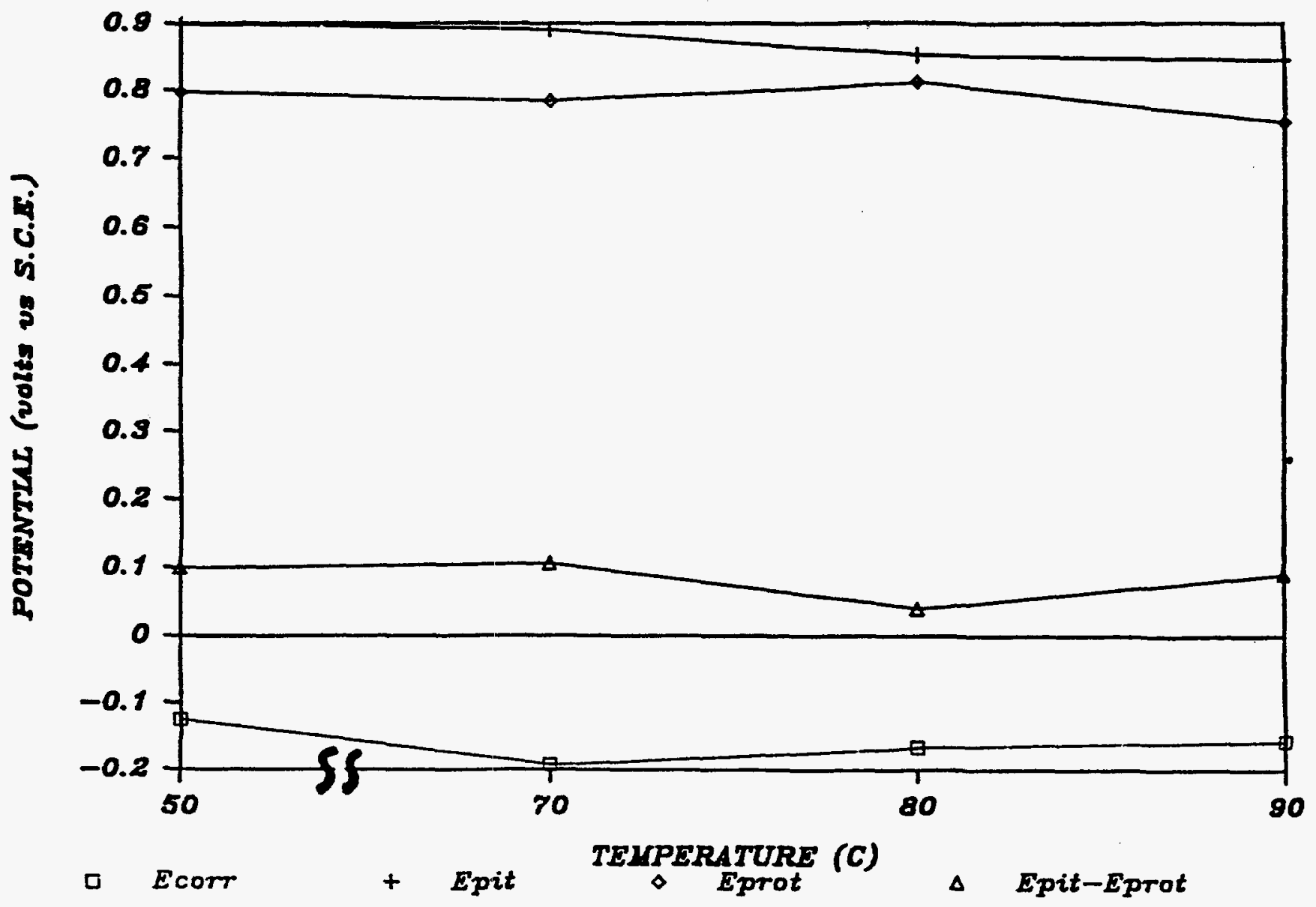

Flgure 3.4 Electrochemlcal Paramoters For 316L Analogous To Those of Flgure 3.3 For 304L. (Glass-1984) 


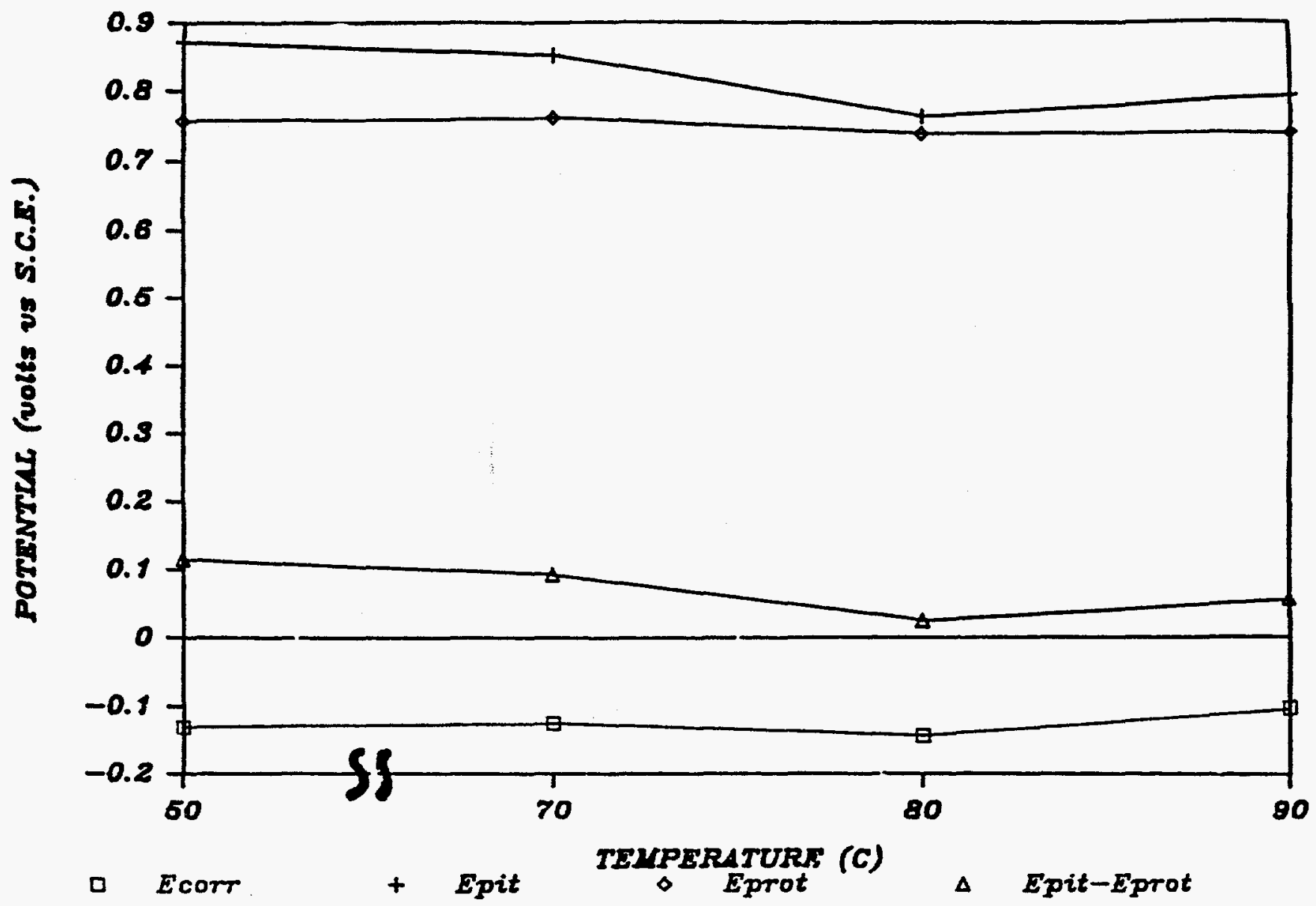

FIgure 3.5 Electrochemical Parameters For I-825 Analogous To Those of Flgure 3.3 For 304L. (Glass-1984) 


\subsubsection{Stress Corrosion Cracking (SCC)}

Environmentally Assisted Cracking (EAS) is defined as the fracture or cracking of a materlal as a result of the conjolnt action of an applled load (stress) and a speclflc corrosive media. EAS encompasses hydrogen embrittlement, corrosion fatlgue as well as stress Corrosion Cracking (SCC). With regard to an $\mathrm{Fe}-\mathrm{Cr}-\mathrm{NI}$ waste contalner, the primary concern is scc.

SCC of Fe-Cr-NI alloys such as Type 304 stalnless steel can occur when the alloy has a desirable solution annealed microstructure but is much more prevalent when the materlal is thermally treated to produce a sensitized microstructure. As described above, sensitization of a stainiess steel occurs as a result of thermal treatments that promote precipltation of chromium carbldes at the graln boundarles and an assoclated depletion of chromium (Andresen-1981). The kinetlcs for sensitization are typlcally lllustrated using a time-temperature sensitization (TTS) curve such as that shown In Flgure 3.6 (Juhas-1984). Varlation In the composition of a stainless steel can move the curve to the left or right, elther promoting or retarding sensitization for a glven thermal history. For example, reducing the carbon content of Type 304 stalniess steel to produce Type $304 \mathrm{~L}$ stainless steel moves the curve to the right.

The actual waste contalner wlll be exposed to a complex thermal history Involving fabrication (welding), waste glass pouring, and long term low temperature exposure in the repository. Thls history is shown schemat Ically in Figure 3.7 (Juhas-1984). Whl le massive chromlum carbldes are not expected to grow in Type 304L stainless steel during the fabrication and glass pouring stages, small carbldes may Initlate during these stages and grow over the many years of required service. Thls phenomenon is known as low temperature sensitization (LTS) and is of concern with regard to the performance of the waste container. Additional information on LTS is given el sewhere (Juhas-1984, Logan-1983, and Fox-1983).

Some of the Initlal work on SCC of $\mathrm{Fe}-\mathrm{Cr}-\mathrm{NI}$ alloys in the Tuff repository was performed by McCright-1984 and Juhas-1984. Slow strain rate (SSR) tests were performed on annealed and sensitized Type 304 and Type 304L stainless steel in air sparged $\mathrm{J}-13$ well water at $150^{\circ} \mathrm{C}$. The major difference in the composition of the two steels was the higher carbon content for the Type 304 stalnless steel; $0.054 \%$ versus $0.024 \%$ carbon. Results of the tests are summarized in Tables 3.3 and 3.4 (Juhas-1984). These data show that the sensitized Type 304 stalnless steel specimens falled by SCC at a strain rate of $2 \times 10^{-7} \mathrm{sec}^{-1}$ in $\mathrm{J}-13$ well water. On the other hand, no SCC was observed on any of the Type 304L stalnless steel specimens.

Juhas-1984 also reported on the results of bent beam stress corrosion tests (ASTM G-39) performed on several austenltic stalnless steel specimens in $\mathrm{J}-13$ water and saturated vapor above the water at $100^{\circ} \mathrm{C}$. Detalls of the experiments and results are given in Table 3.5 (Juhas-1984). These data show that no SCC was observed within 4,016 hours of exposure for cold worked, sensitized and welded specimens.

Pitman-1986 reported on an extension of the SSR work previously reported by Juhas-1984. Intermedlate strain rates were evaluated for Type 304 and $304 \mathrm{~L}$ stalnless steels. Type $316 \mathrm{~L}$ stalnless steel also was studled and 


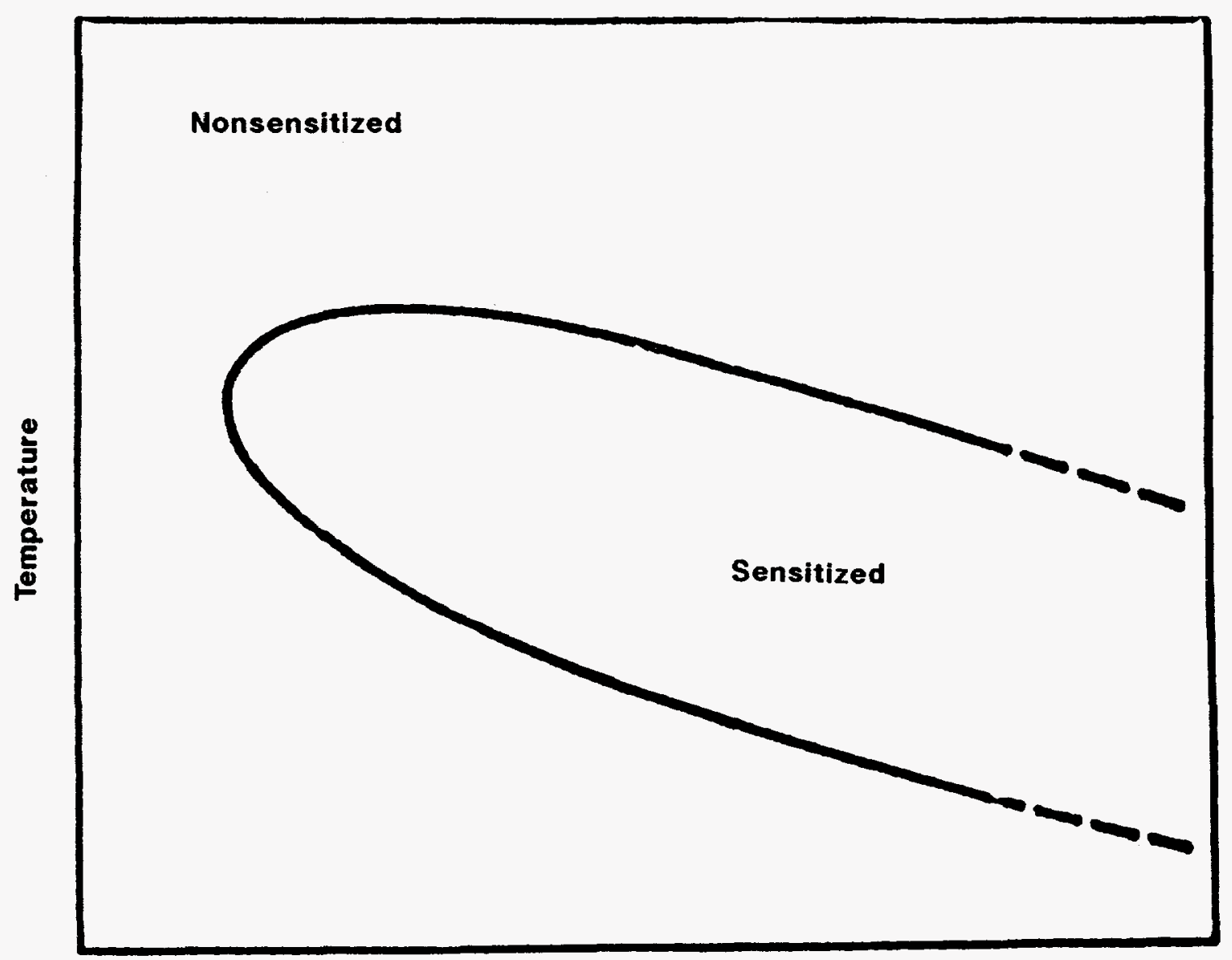

Time

Flgure 3.6 Schematlc TImo, Temperature, Sensltizatlon (TTS) Dlagram. (Juhas-1984) 


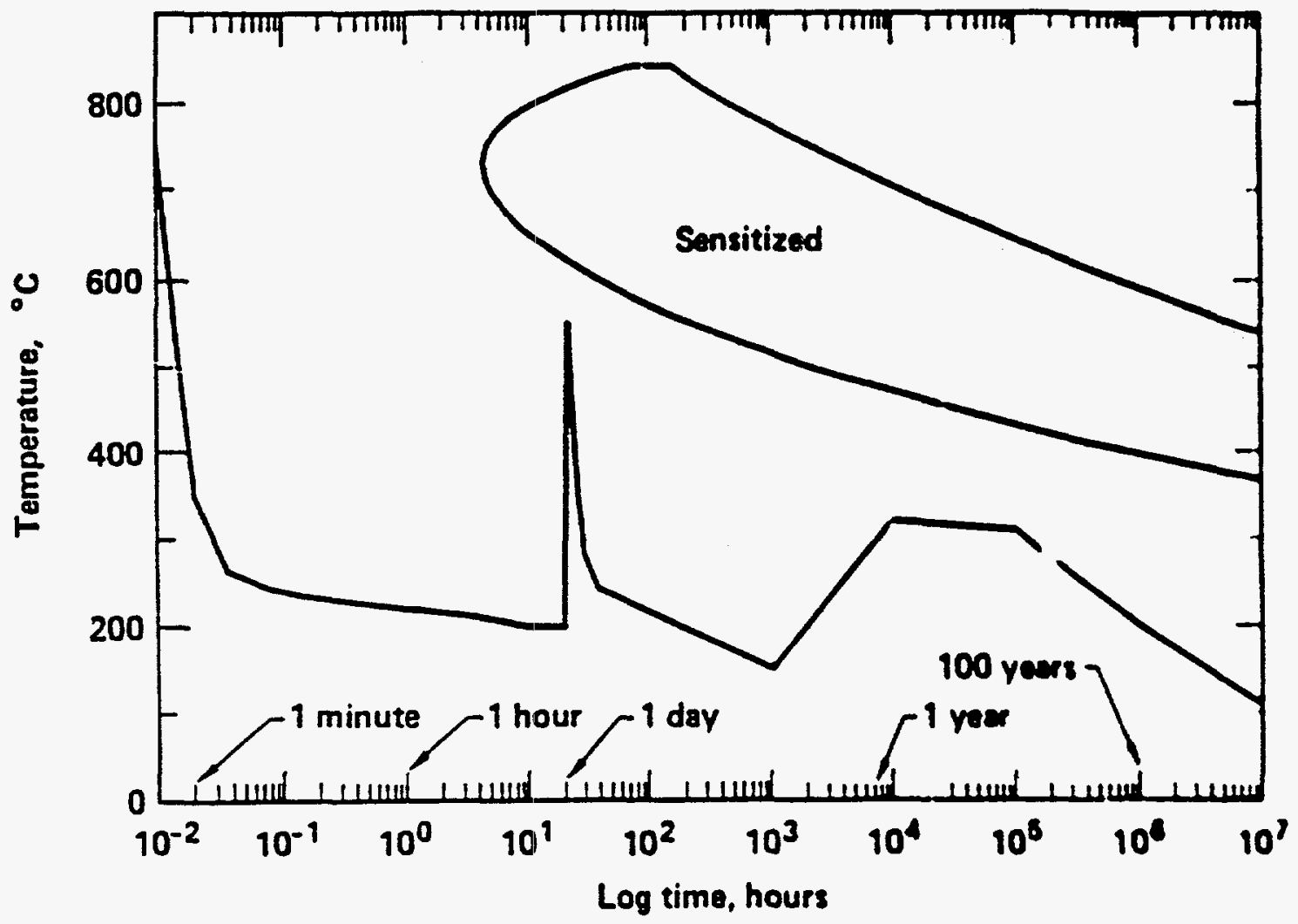

FIgure 3.7 Computer Simulation of Type 304 Stainless Steel Canlster. Thermal History Showing Melding, Glass-Pouring, And Storage. (Juhas-1984) 
Table 3.3 Results of Slow straln Rate Tests of 304 Stalniess Steel At $150^{\circ} \mathrm{C}$. (Junas-1984)

Mill Annealed Specimens

\begin{tabular}{|c|c|c|c|c|c|}
\hline Environment & $\begin{array}{c}\text { Strain } \\
\text { Rate }\end{array}$ & $\begin{array}{l}\text { Reduction } \\
\text { of Area, } \\
\text { Percent }\end{array}$ & $\begin{array}{l}\text { Elongation } \\
\text { Percent }\end{array}$ & $\begin{array}{c}\text { Yield } \\
\text { Strength, } \\
\text { ksi }\end{array}$ & $\begin{array}{c}\text { Ultimate } \\
\text { Strength } \\
\text { ksi }\end{array}$ \\
\hline Air & $1 E-4 / 5$ & 80.2 & 48 & 37.4 & 74.4 \\
\hline Air & $2 E-7 / 5$ & 76.5 & 45 & 35.9 & 76.6 \\
\hline $\mathrm{J}-13$ (1) & $1 E-4 / 5$ & 77.9 & 47 & 36.1 & 75.3 \\
\hline$J-13$ & $1 E-4 / 5$ & 79.6 & 46 & 36.3 & 74.9 \\
\hline$J-13$ & $2 E-7 / 5$ & 75.7 & 50 & 33.5 & 77.5 \\
\hline$J-13$ & $2 E-7 / 5$ & 76.4 & 47 & 35.1 & 77.0 \\
\hline
\end{tabular}

Solution Annealed and Sensitized Specimens (2)

$\begin{array}{ccccccc}\text { Environment } & \begin{array}{c}\text { Strain } \\ \text { Rate }\end{array} & \begin{array}{c}\text { Reduction } \\ \text { of Area, } \\ \text { Percent }\end{array} & \begin{array}{c}\text { Elongation } \\ \text { Percent }\end{array} & \begin{array}{c}\text { Yield } \\ \text { Stength, } \\ \text { ksi }\end{array} & \begin{array}{c}\text { Ultimate } \\ \text { Strength, } \\ \text { ksi }\end{array} & \text { ScC } \\ \text { Air } & 1 E-4 / 5 & 72.2 & 50.6 & 21.9 & 68.0 & \\ \mathrm{~J}-13 & 1 E-4 / 5 & 66.5 & 51.5 & 26.0 & 68.8 & \text { No } \\ \mathrm{J}-13 & 1 E-4 / 5 & 75.5 & 53.5 & 23.5 & 68.8 & \text { No } \\ \mathrm{J}-13 & 2 E-7 / 5 & 74.9 & 51.0 & 23.5 & 69.0 & \text { Yes } \\ \mathrm{J}-13 & 2 E-7 / 5 & 25.4 & ---(3) & 22.0 & 70.1 & \text { Yes }\end{array}$

(1) Alr-sparged J-13 well water.

(2) $1050^{\circ} \mathrm{C}$ for $15 \mathrm{minutes}$, water quenched and $600^{\circ} \mathrm{C}$ for 24 hours, alr cooled.

(3) Not determined.

(4) Broke at gage mark. 
Table 3.4 Results of Slow strain Rate Tests of $304 \mathrm{~L}$. Stainless Steel At $150^{\circ} \mathrm{C}$. ( Juhas-1984)

Solution Annealed Specimens (1)

$\begin{array}{ccccccc}\text { Environment } & \begin{array}{c}\text { Strain } \\ \text { Rate }\end{array} & \begin{array}{c}\text { Reduction } \\ \text { of Area, } \\ \text { Percent }\end{array} & \begin{array}{c}\text { Elongation } \\ \text { Percent }\end{array} & \begin{array}{c}\text { Yield } \\ \text { Stength, } \\ \text { ksi }\end{array} & \begin{array}{c}\text { Ultimate } \\ \text { Strength, } \\ \text { ksi }\end{array} & \text { Scc } \\ \mathrm{J}-13(3) & 1 E-4 / 5 & 80.5 & 54.0 & 25.8 & 68.4 & \text { No } \\ J-13 & 1 E-4 / 5 & 78.4 & 52.0 & 27.1 & 68.2 & \text { No } \\ J-13 & 2 E-7 / 5 & 68.7 & 48.0 & 28.4 & 67.7 & \text { No } \\ J-13 & 2 E-7 / 5 & 72.9 & 46.3 & 26.7 & 68.2 & \text { No }\end{array}$

Solution Annealed and Sensitized Specimens

\begin{tabular}{|c|c|c|c|c|c|c|}
\hline Environment & $\begin{array}{c}\text { Strain } \\
\text { Rate }\end{array}$ & $\begin{array}{l}\text { Reduction } \\
\text { of Area, } \\
\text { Percent }\end{array}$ & $\begin{array}{l}\text { El ongation } \\
\text { Percent }\end{array}$ & $\begin{array}{c}\text { Yield } \\
\text { strength, } \\
\text { ksi }\end{array}$ & $\begin{array}{c}\text { Ultimate } \\
\text { Strength, } \\
\text { ksi }\end{array}$ & scc \\
\hline Air & $1 E-4 / 5$ & 73.7 & 49.0 & 29.4 & 68.6 & \\
\hline$J-13$ & $1 E-4 / 5$ & 72.2 & 49.6 & $---(4)$ & $-(4)$ & No \\
\hline$J-13$ & $1 E-4 / 5$ & 74.8 & 51.6 & 29.6 & 69.1 & No \\
\hline$J-13$ & $2 E-7 / 3$ & 76.0 & 49.0 & 26.6 & 68.8 & No \\
\hline $\mathrm{J}-13$ & $2 E-7 / 5$ & 70.4 & 48.0 & 27.2 & 68.8 & No \\
\hline
\end{tabular}

(1) $1050^{\circ} \mathrm{C}$ for 15 minutes and water quenched.

(2) Solution annealed and $600^{\circ} \mathrm{C}$ for 10 hours, alr cooled.

(3) Alr-sparged $\mathrm{J}-13$ well water.

(4) Not determIned. 
Table 3.5 status of stress corrosion Cracking Test Results For Four-Polnt Load. Bent-Beam Specimens Exposed To $J-13$ Water And Steam And Stressed to $90 \%$ Yleid stress. (Juhas-1984)

Material and Process Condition

304 - CW5*

304L - CSW

$316 L$ - CSW

321 - Csw
$100 \mathrm{C} \mathrm{J}-13$ Water No. Specimens Cracked/ No. Specimens Tested

$0 / 9$

$0 / 9$

$0 / 9$

$0 / 9$
$100 C$ Steam

No. Specimens Cracked/ No. Specimens Tested
Exposure Hrs

4016

4016

4016

4016
$0 / 9$

$0 / 9$

$0 / 9$

$0 / 9$

$\begin{array}{llll}304-\text { COW* } & 2000 & 0 / 3 & 0 / 3 \\ 304 L-\text { COW } & 2000 & 0 / 3 & 0 / 3 \\ 316 L-\text { COW } & 2000 & 0 / 3 & 0 / 3 \\ 321-\text { COW } & 2000 & 0 / 3 & 0 / 3\end{array}$

*KEY

$c=$ Cold-Worked, $20 \%$

$S$ = Furnace "Sensitized" (700C For 8 Hours)

$w=$ Doubler-Pass Welded

0 acts as a placeholder For Each of The Above Specimens 
other sensitization heat treatments and lower temperatures were evaluated. A summary of the results is given in Tables 3.6-3.8 ( $P$ Itman-1986). As was prevlously observed, only sensltized 304 stalnless steel was found to be susceptible to SCC in $150^{\circ} \mathrm{C} \mathrm{J-13}$ groundwater. In addition, susceptibility was I ImIted to strain rates equal to or less than $1 \times 10^{-6} \sec ^{-1}$. Nelther Type 304 stainless steel or Type $316 \mathrm{~L}$ stainless steel exhlbited SCC susceptiblilty at $95^{\circ} \mathrm{C}$ and a strain rate of $1 \times 10^{-6} \mathrm{sec}^{-1}$. Both were tested in the sensitized condltion as shown in Table 3.8 (PItman-1986).

Abraham-1986 exposed $V$-notched C-rIng specimens of several Fe-Cr-NI alloys to bolling synthetlC J-13 well water and to the steam phase of the bolling solutions. ASTM procedure G-38 was used for the testing. All specimens were in contact with crushed Tuff during the exposures. The test duratlons were 3,6 and 12 months. Four alloys were evaluated: Type 304L stainless steel, Type 316L stalnless steel, Type 321 stainless steel and Incoloy Alloy 825. Their chemlcal compositions are given in Table 3.9 (Abraham-1986). Both solutions annealed (SA) and SA plus sensitized heat treatments were evaluated. The sensitization heat treatment consisted of 100 hours at $600^{\circ} \mathrm{C}$ followed by furnace cooling. The solution annealed condition was as-recelved. All specimens were stressed at room temperature to $90 \%$ of the elastic $\mid \mathrm{Imlt}$, calculated for unnotched specimens. The test matrix for the experiments is given in Table 3.10 (Abraham-1986).

No macro-cracking was observed on any of the specimens tested. However, fine microcracks were detected on specimens of Type 304L stainless steel, Type 316L stainless steel and Type 321 stainless steel. One specimen of Incoloy Alloy 825 also was found to contain mlcrocracks. These cracks were generally less than $2 \mathrm{mils}(50 \mathrm{um})$ deep and the occurrence and depth did not correlate with heat treatment or test time. A summary of the results is given in Tables 3.11-3.15 ((Abraham-1986). While the authors apparently are convinced that the microcracks are incipient stress corrosion cracks, the evidence is not convincing. Thelr appearance, which is not typlcally of SCC, and the poor correlation with test parameters suggests that the microcracks are nonpropagating preexisting flaws or the result of corrosion attack of near-surface inclusions. In any case, much more extensive data would be required to confirm or refute the authors contentions.

\subsection{Cu Base Alloys}

\subsubsection{General Corrosion}

McCright-1985 performed gravimetric corrosion tests on candlate copper base alloys in $\mathrm{J}-13$ well water and steam generated from that water. ASTM G-1 and G-31 test procedures were used and the experimental detalls were similar to those reported by McCright-1983 and Juhas-1984 for stainless steels. The chemical compositions of the three candidate alloys evaluated are given in Table 3.16 (McCright-1985). Also included in the tests were three other copper containing alloys, CDA 110, CDA 706 and Monel 400, for compar Ison purposes.

Results of the tests are summarized in Table 3.17 (McCright-1985). These data show that the copper alloys exhiblted low to moderate corrosion rates in the test environments. Rates appear to be somewhat lower in dry steam at $150^{\circ} \mathrm{C}$ than in wet steam at $100^{\circ} \mathrm{C}$. Corrosion rates in wet steam were silghtly higher than in J-13 water at $100^{\circ} \mathrm{C}$ for CDA 102 and CDA 613 . On 
Table 3.6 Slow-Straln-Rate Test Results For Type 304 Stalnless Steel At $150^{\circ} \mathrm{C}$. (PItman-1986)

\section{Mill-Annealed Soecimens}

\begin{tabular}{|c|c|c|c|c|c|c|}
\hline $\begin{array}{l}\text { Specimen } \\
\text { Number }\end{array}$ & Environment & $\begin{array}{l}\text { Strain Rate } \\
\text { in./in.-5 } \\
\end{array}$ & $\begin{array}{c}\text { Reduction } \\
\text { of Area, } \\
\%\end{array}$ & Elongation, & $\begin{array}{c}\text { Yield } \\
\text { Strength, } \\
\text { ksi }\end{array}$ & $\begin{array}{c}\text { Ultimate } \\
\text { Strength, } \\
\text { ksi } \\
\end{array}$ \\
\hline P405 & air & $1 \times 10^{-4}$ & 80 & 48 & 37.4 & 74.4 \\
\hline 9406 & air & $2 \times 10^{-7}$ & 76 & 45 & 35.9 & 76.8 \\
\hline P403 & air & $5 \times 10^{-6}$ & 74 & 46 & 36.6 & 75.7 \\
\hline$P 400$ & ajr & $5 \times 10^{-6}$ & 73 & 45 & 34.0 & 74.7 \\
\hline P395 & $j-13^{(a)}$ & $5 \times 10^{-5}$ & 79 & 46 & 36.8 & 76.1 \\
\hline P396 & $\mathrm{J}-13$ & $5 \times 10^{-6}$ & 68 & 47 & 34.5 & 75.2 \\
\hline P397 & $j-13$ & $1 \times 10^{-4}$ & 78 & 47 & 36.1 & 75.3 \\
\hline P404 & $J-13$ & $1 \times 10^{-4}$ & 80 & 46 & 36.3 & 74.9 \\
\hline$P 401$ & $J-13$ & $2 \times 10^{-7}$ & 76 & 50 & 33.5 & 77.5 \\
\hline P402 & $J-13$ & $2 \times 10^{-7}$ & 76 & 47 & 35.1 & 77.0 \\
\hline
\end{tabular}

Solution-Annealed and Sensitized (b) Soecimens

\begin{tabular}{|c|c|c|c|c|c|c|}
\hline $\begin{array}{l}\text { Specimen } \\
\text { Number } \\
\end{array}$ & Environment & $\begin{array}{l}\text { Strain Rate } \\
\text { in./in.-s } \\
\end{array}$ & $\begin{array}{c}\text { Reduction } \\
\text { of Area, } \\
\% \\
\end{array}$ & Elongation, & $\begin{array}{c}\text { Yield } \\
\text { Strength, } \\
\text { ksi } \\
\end{array}$ & $\begin{array}{c}\text { Ultimate } \\
\text { Strength, } \\
\text { ksi } \\
\end{array}$ \\
\hline$P 413$ & air & $1 \times 10^{-4}$ & 72 & 52 & 21.9 & 68.0 \\
\hline P415 & air & $1 \times 10^{-4}$ & 67 & 52 & 26.0 & 68.8 \\
\hline P409 & air & $5 \times 10^{-6}$ & 73 & 50 & 22.4 & 68.5 \\
\hline P417 & air & $5 \times 10^{-6}$ & 67 & 50 & 18.6 & 69.9 \\
\hline P412 & $3-13$ & $5 \times 10^{-6}$ & 74 & 51 & 20.2 & 69.3 \\
\hline P41I & $J-13$ & $5 \times 10^{-6}$ & 79 & 49 & 21.7 & 68.5 \\
\hline P410 & $J-13$ & $1 \times 10^{-6}$ & 58 & 35 & 19.8 & 65.5 \\
\hline P407 & $\mathrm{J}-13$ & $1 \times 10^{-4}$ & 76 & 54 & 23.5 & 68.8 \\
\hline P408 & $J-13$ & $1 \times 10^{-4}$ & 75 & 51 & 23.5 & 69.0 \\
\hline P414 & $j-13$ & $2 \times 10^{-7}$ & 51 & (c) & 22.0 & 70.1 \\
\hline$P 416$ & $d-13$ & $2 \times 10^{-7}$ & 26 & (d) & 20.7 & 64.5 \\
\hline
\end{tabular}
(a) "J-13" refers to air-sparged $J-13$ well water
(b) Sensitized $24 \mathrm{~h}$ at $600^{\circ} \mathrm{C}$
(c) Not determined
(d) Broke at gage mark 
Table 3.7 Slow-strain-hate Test Results For Type $304 \mathrm{~L}$ stainless Steol At $150^{\circ} \mathrm{C}$. (P/tman-1986)

Solution-Annealed Soecimens

\begin{tabular}{|c|c|c|c|c|c|c|}
\hline $\begin{array}{l}\text { Specimen } \\
\text { Number } \\
\end{array}$ & Environment & $\begin{array}{l}\text { Strain Rate } \\
\text { in./in.-5 } \\
\end{array}$ & $\begin{array}{c}\text { Reduction } \\
\text { of Area, } \\
7\end{array}$ & Elongation, & $\begin{array}{c}\text { Yield } \\
\text { Strength, } \\
\text { ksi } \\
\end{array}$ & $\begin{array}{c}\text { Ultimate } \\
\text { Strength, } \\
\text { ksi } \\
\end{array}$ \\
\hline $\mathrm{P} 234$ (a) & $\mathrm{J}-13(b)$ & $1 \times 10^{-4}$ & 81 & 54 & 25.8 & 68.4 \\
\hline$P 235$ (a) & $J-13$ & $1 \times 10^{-4}$ & 78 & 52 & 27.1 & 68.2 \\
\hline P233(a) & $J-13$ & $2 \times 10^{-7}$ & 69 & 48 & 28.4 & 67.7 \\
\hline$P 23 \sigma^{\text {(a) }}$ & $d-13$ & $2 \times 10^{-7}$ & 73 & 46 & 26.7 & 68.2 \\
\hline$p 378(c)$ & air & $1 \times 10^{-6}$ & 74 & 48 & 26.4 & 69.0 \\
\hline$P 372(c)$ & $\operatorname{air}$ & $1 \times 10^{-6}$ & 79 & 52 & 25.9 & 69.4 \\
\hline$p 382(c)$ & $J-13$ & $1 \times 10^{-6}$ & 69 & 52 & $-(d)$ & $-(d)$ \\
\hline
\end{tabular}

Solution-Annealed and Sensitized Soecimens

\begin{tabular}{|c|c|c|c|c|c|c|}
\hline $\begin{array}{l}\text { Specimen } \\
\text { Number }\end{array}$ & Environment & $\begin{array}{l}\text { Strain Rate } \\
\text { in, /in. -s } \\
\end{array}$ & $\begin{array}{c}\text { Reduction } \\
\text { of Area, } \\
\% \\
\end{array}$ & Elongation, & $\begin{array}{c}\text { Yield } \\
\text { Strength, } \\
\text { ksi }\end{array}$ & $\begin{array}{c}\text { Ultimate } \\
\text { Strength, } \\
\text { ksi } \\
\end{array}$ \\
\hline$P 243(e)$ & air & $1 \times 10^{-4}$ & 74 & 49 & 29.4 & 68.6 \\
\hline p239(e) & $J-13$ & $1 \times 10^{-4}$ & 72 & 50 & $-(d)$ & $\ldots$ (d) \\
\hline$P 240$ (e) & $\mathrm{J}-13$ & $1 \times 10^{-4}$ & 75 & 52 & 29.5 & 69.1 \\
\hline$p_{241}(e)$ & $J-13$ & $2 \times 10^{-7}$ & 76 & 49 & 26.5 & 68.8 \\
\hline$P_{244}(e)$ & $J-13$ & $2 \times 10^{-7}$ & 70 & 48 & 27.2 & 68.8 \\
\hline$p 384$ (f) & air & $1 \times 10^{-6}$ & 72 & 53 & 19.3 & 64.6 \\
\hline$P 393(f)$ & air & $1 \times 10^{-6}$ & 69 & 50 & 20.4 & 63.9 \\
\hline$P 387^{(f)}$ & $\mathrm{J}-13$ & $1 \times 10^{-6}$ & 57 & 51 & 21.5 & 65.1 \\
\hline$P 385^{(f)}$ & $j-13$ & $1 \times 10^{-6}$ & 70 & 53 & 20.6 & 65.4 \\
\hline
\end{tabular}

(a) Specimens P233 and P244 are from heat $A$

(b) Air-sparged $\mathrm{J}-13$ well water

(c) Specimens P371 to P394 are from heat $B$

(d) Not determined because of equipment malfunction

(e) Sensitjzed $10 \mathrm{~h}$ at $600^{\circ} \mathrm{C}$, air cooled

(f) Sensitized $24 \mathrm{~h}$ at $600^{\circ} \mathrm{C}$, air cooled 
Table 3.8 Slow-Straln-Rate Test Results For Type 304 And Type 316L stainless steol at $95^{\circ} \mathrm{C}$ And A strain Rate of $1 \times 10^{-6} / \mathrm{s}$. (PItman-1986)

Type 304 Stainless Steel

\begin{tabular}{|c|c|c|c|c|c|c|}
\hline $\begin{array}{l}\text { Specimen } \\
\text { Number }\end{array}$ & Environment & $\begin{array}{l}\text { Sensitization } \\
\text { Heat Treatment }\end{array}$ & $\begin{array}{c}\text { Reduction } \\
\text { of Area, } \\
\vdots\end{array}$ & Elongation, & $\begin{array}{c}\text { Yield } \\
\text { Strength, } \\
\text { ksi } \\
\end{array}$ & $\begin{array}{c}\text { Ultimate } \\
\text { Strength, } \\
\text { ksi } \\
\end{array}$ \\
\hline 151 & air & ${\underset{w O}{(\mathrm{a})}}^{\mathrm{k}}$ at $700^{\circ} \mathrm{C}$, & 57 & 34 & 66.2 & 91.7 \\
\hline 152 & air & $\begin{array}{l}1 \text { wk at } 700^{\circ} \mathrm{C} \text {, } \\
\text { WQ }\end{array}$ & 56 & 33 & 70.8 & 91.5 \\
\hline 153 & $\mathrm{~J}-13$ & $1_{\text {wQ }}$ wh at $700^{\circ} \mathrm{C}$, & 57 & 35 & 68.3 & 89.9 \\
\hline 154 & $3-13$ & $\begin{array}{l}1 \text { wk at } 700^{\circ} \mathrm{C} \text {, } \\
\text { WQ }\end{array}$ & 62 & 34 & 69.0 & 90.4 \\
\hline
\end{tabular}

Type 316L Stainiess Steel

\begin{tabular}{|c|c|c|c|c|c|c|}
\hline $\begin{array}{l}\text { Specimen } \\
\text { Number }\end{array}$ & Environment & $\begin{array}{l}\text { Sensitization } \\
\text { Heat Treatment }\end{array}$ & $\begin{array}{l}\text { Reduction } \\
\text { of Area, } \\
\end{array}$ & Elongation, & $\begin{array}{c}\text { Yield } \\
\text { Strength, } \\
\text { ksi } \\
\end{array}$ & $\begin{array}{c}\text { Ultimate } \\
\text { Strength, } \\
\mathrm{ksi} \\
\end{array}$ \\
\hline 121 & air & $\begin{array}{l}1 \text { day at } 250^{\circ} \mathrm{C} \text {, } \\
\text { WQ }\end{array}$ & 54 & 17 & 101.1 & 106.1 \\
\hline 122 & $j-13$ & $\begin{array}{l}\text { 1. day at } 250^{\circ} \mathrm{C} \text {, } \\
\text { wQ }\end{array}$ & 56 & 16 & 100.9 & 106.5 \\
\hline 123 & $J-13$ & ${ }_{\text {WQ }}^{1}$ day at $250^{\circ} \mathrm{C}$, & 54 & 16 & 100.8 & 107.8 \\
\hline 124 & $J-13$ & 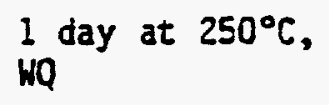 & 53 & 16 & 100.6 & 106.4 \\
\hline 125 & air & ${ }_{\text {WQ }}^{1}$ day at $250^{\circ} \mathrm{C}$, & 54 & 16 & 97.0 & 107.2 \\
\hline 132 & $J-13$ & $\begin{array}{l}1 \text { wk at } 250^{\circ} \mathrm{C} \text {, } \\
\text { WQ }\end{array}$ & 47 & 12 & 109.5 & 114.5 \\
\hline 133 & air & $I_{\text {WQ }}$ wk at $250^{\circ} \mathrm{C}$, & 51 & 13 & 111.6 & 117.0 \\
\hline 134 & air & $\begin{array}{l}1 \text { wk at } 250^{\circ} \mathrm{C} \text {, } \\
\text { WQ }\end{array}$ & 48 & 13 & 105.7 & 113.1 \\
\hline 135 & $J-13$ & ${ }_{\text {WQ }}^{1}$ wh at $250^{\circ} \mathrm{C}$, & 47 & 13 & 105.2 & 112.3 \\
\hline
\end{tabular}

(a) Water quench 
Table 3.9 Vendor Supplled Chemlcal Analysis of Test Alloys (Welght Percent). (Abrahan-1986)

\begin{tabular}{|c|c|c|c|c|c|c|c|c|c|c|c|}
\hline Alloy & C & $\mathrm{M}$ & Si & $\mathbf{P}$ & $\mathbf{S}$ & Cr & $N i$ & Mo & Ti & Al & Fe \\
\hline $\begin{array}{l}\text { Type } \\
304 \mathrm{~L} \text { SS }\end{array}$ & 0.016 & 1.95 & 0.48 & 0.038 & 0.025 & 18.54 & 10.55 & - & - & - & Balance \\
\hline 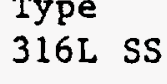 & 0.016 & 1.94 & 0.37 & 0.035 & 0.010 & 16.66 & 12.80 & 2.02 & - & - & Balance \\
\hline $\begin{array}{l}\text { Type } \\
321 \text { sS }\end{array}$ & 0.028 & 1.03 & 0.74 & 0.026 & 0.002 & 17.41 & 10.75 & - & 0.24 & - & Balance \\
\hline 825 & 0.020 & 0.44 & 0.27 & - & 0.001 & 22.34 & 44.14 & 2.78 & 0.84 & 0.07 & 27.26 \\
\hline
\end{tabular}


Table 3.10 Test Matrlx For Stress Corrosion of Candidate stainless steel And Incoloy-825 ${ }^{\mathrm{a}}$. (Abraham-1986)

\begin{tabular}{|c|c|c|c|c|}
\hline \multirow[b]{2}{*}{ Sample Condition } & \multirow[b]{2}{*}{ Exposure Medium ${ }^{b}$} & \multicolumn{3}{|c|}{$\begin{array}{l}\text { Total Exposure Time } \\
\text { and Number of Samples }\end{array}$} \\
\hline & & 3 Months & 6 Months & 12 Months \\
\hline $\begin{array}{l}\text { Solution Annealed (SA) } \\
\text { SA + Sensitized } \\
\text { SA } \\
\text { SA + Sensitized } \\
\text { SA } \\
\text { SA + Sensitized } \\
\text { SA } \\
\text { SA + Sensitized }\end{array}$ & $\begin{array}{l}J-13 \text { Steam } \\
J-13 \text { Steam } \\
J-13 \text { Water } \\
J-13 \text { Water } \\
(J-13 \text { Steam }) \times 10 c \\
(J-13 \text { Steam }) \times 10 \\
(J-13 \text { Water }) \times 10 \\
(J-13 \text { Water }) \times 10\end{array}$ & $\begin{array}{l}3 \\
3 \\
3 \\
3 \\
3 \\
3 \\
3 \\
3\end{array}$ & $\begin{array}{l}3 \\
3 \\
3 \\
3 \\
3 \\
3 \\
3 \\
3 \\
3\end{array}$ & $\begin{array}{l}3 \\
3 \\
3 \\
3 \\
3 \\
3 \\
3 \\
3 \\
3\end{array}$ \\
\hline \multicolumn{5}{|c|}{$\begin{array}{l}\text { a) This test matrix comprising } 72 \text { samples constituted the tests on one of the } \\
\text { four candidate materials. An identical matrix were used for all eight } \\
\text { materials and the total number of all specimens tested were } 288 \text {. } \\
\text { b) All tests were conducted in the presence of crushed tuff. } \\
\text { c) This environment was the steam/air phase above } 10 \mathrm{x} \text { concentrated J-13 well } \\
\text { water. }\end{array}$} \\
\hline
\end{tabular}


Table 3.11 Stress Corrosion Cracking Tests For Type 304L Stalnless steel. (Abraham-1986)

\begin{tabular}{|c|c|c|c|c|c|}
\hline \multirow{2}{*}{$\begin{array}{l}\text { Test Time } \\
\text { (months) }\end{array}$} & \multirow{2}{*}{$\begin{array}{l}\text { Spectmen } \\
\text { Condittons }\end{array}$} & \multicolumn{2}{|c|}{ Steam Test } & \multicolumn{2}{|c|}{$\begin{array}{l}\text { Water Test } \\
\end{array}$} \\
\hline & & $\mathrm{J}-13$ Water $^{\mathrm{a}}$ & $10 \times \mathrm{J}-13$ Water ${ }^{\mathrm{a}}$ & $\mathrm{J}-13$ Water $^{\mathrm{a}}$ & $10 \times \mathrm{J}-13$ Water ${ }^{a}$ \\
\hline \multirow[t]{2}{*}{3} & As Received & $\begin{array}{l}2 / 2^{b} \\
28 \mu^{c}\end{array}$ & H.E. & N.E. & N.E. \\
\hline & Sensitized & N.E.d & $0 / 2$ & N.E. & N.E. \\
\hline \multirow{2}{*}{6} & As Recelved & $\begin{array}{l}2 / 2 \\
13 u\end{array}$ & $\begin{array}{l}2 / 2 \\
27 \mu\end{array}$ & $\begin{array}{l}1 / 2 \\
28 \mu\end{array}$ & $\begin{array}{l}1 / 2 \\
27 \mu\end{array}$ \\
\hline & Sengltized & $0 / 2$ & $\begin{array}{l}2 / 2 \\
19 \mu\end{array}$ & $0 / 1$ & $\begin{array}{c}1 / 2 \\
16 \mu(\text { notch })\end{array}$ \\
\hline \multirow{2}{*}{12} & As Recelved & $\begin{array}{l}1 / 2 \\
7 \mu\end{array}$ & $0 / 2$ & $\begin{array}{l}1 / 1 \\
2611\end{array}$ & $\begin{array}{l}1 / 2 \\
7 \mu\end{array}$ \\
\hline & Sensitized & $0 / 1$ & $\begin{array}{l}1 / 1 \\
26 \mu\end{array}$ & $\begin{array}{l}1 / 1 \\
43 \mu\end{array}$ & $0 / 1$ \\
\hline
\end{tabular}

a) The composition of test solution changes substantially with time.

b) Specinens with microcracks/number of spectmens examined.

c) Maximum crack length in $\mu$.

d) Not examined (N.E.). 
Table 3.12 stress Corrosion Cracking Tests For Type 316L Stalnless steel. (Abraham-1986)

\begin{tabular}{|c|c|c|c|c|c|}
\hline \multirow{2}{*}{$\begin{array}{c}\text { Test Tiae } \\
\text { (Months) }\end{array}$} & \multirow{2}{*}{$\begin{array}{l}\text { Specimen } \\
\text { Conditions }\end{array}$} & \multicolumn{2}{|c|}{ Steam Test } & \multicolumn{2}{|c|}{ Water Test } \\
\hline & & $\mathrm{J}-13$ Water ${ }^{2}$ & $10 \times \mathrm{J}-13$ Water $\mathrm{r}^{2}$ & $\mathrm{~J}-13$ Water $^{\mathrm{a}}$ & $10 \times \mathrm{J}-13$ Water $^{\mathrm{a}}$ \\
\hline \multirow[t]{2}{*}{3} & As Recelved & N.E.b & N.E. & $\begin{array}{l}2 / 2 c \\
21 \mu^{d}\end{array}$ & N.E. \\
\hline & Sensitized & N.E. & $\begin{array}{l}2 / 2 \\
23 \mu\end{array}$ & N.E. & N.E. \\
\hline \multirow{2}{*}{6} & As Recelved & $\begin{array}{l}1 / 1 \\
13 \mu(\text { notch } \\
\text { root) }\end{array}$ & $\begin{array}{l}2 / 2 \\
20 \mu\end{array}$ & $\begin{array}{l}2 / 2 \\
24 \mu \text { (1 at } \\
\text { notch root) }\end{array}$ & $\begin{array}{l}2 / 2 \\
12 \text { (both } \\
\text { notches) }\end{array}$ \\
\hline & Sensitlzed & $\begin{array}{l}1 / 2 \\
25 \mu\end{array}$ & $\begin{array}{l}1 / 3 \\
5 \mu\end{array}$ & $\begin{array}{l}2 / 2 \\
20 \mu \text { (1 at } \\
\text { notch root) }\end{array}$ & $\begin{array}{l}2 / 2 \\
14 \mu\end{array}$ \\
\hline \multirow{2}{*}{12} & As Received & $\begin{array}{l}1 / 1 \\
26 \mu\end{array}$ & $\begin{array}{l}1 / 2 \\
20 \mu\end{array}$ & $\begin{array}{l}2 / 2 \\
18 \mu\end{array}$ & $0 / 1$ \\
\hline & Seng1tized & $\begin{array}{l}\text { (difficult to } \\
\text { identify due } \\
\text { to heavy } \\
\text { etching) }\end{array}$ & N.B. & $\begin{array}{l}\quad 0 / 1 \\
\text { (possible } \\
\text { transgranular } \\
\text { crack } \\
\text { Inttiation) }\end{array}$ & $0 / 1$ \\
\hline
\end{tabular}

a) The composition of test solution changes substantially with time.

b) Not examined (N.E.)

c) Specimens with microcracks/number of specimens examined. Some starting material had minute cracks, which could Influence crack initiation data. See text for discussion.

d) Maximum crack length in $\mu$. 
Table 3.13 Stress Corroslon Cracklng Tests For Typo 321 Stalnless Steol. (Abraham-1986)

\begin{tabular}{|c|c|c|c|c|c|}
\hline \multirow{2}{*}{$\begin{array}{c}\text { Teat Time } \\
\text { (Months) }\end{array}$} & \multirow{2}{*}{$\begin{array}{l}\text { Specimen } \\
\text { Conditions }\end{array}$} & \multicolumn{2}{|c|}{ Steam Test } & \multicolumn{2}{|c|}{ Wacer Test } \\
\hline & & $\mathrm{J}-13$ Water $^{\mathrm{a}}$ & $10 \times J-13$ Water & $\mathrm{J}-13$ Water & $10 \times J-13^{8}$ \\
\hline \multirow[t]{2}{*}{3} & As Recelved & N.E.b & N.E. & $\begin{array}{l}\text { N.E. } \\
21 \mu\end{array}$ & N.E. \\
\hline & Sensitized & N.E. & N.E. & N.E. & $0 / 2$ \\
\hline \multirow{2}{*}{6} & As Recelved & N.E. & $\begin{array}{l}2 / 2 c \\
25 y^{d}\end{array}$ & N.E. & $\begin{array}{l}2 / 2 \\
55 \mu\end{array}$ \\
\hline & Sensitized & N.E. & $0 / 2$ & N.E. & $\begin{array}{l}1 / 2 \\
25 u\end{array}$ \\
\hline \multirow{2}{*}{12} & As Recelved & $0 / 1$ & N.E. & $\mathbf{H} \cdot \mathbf{E}$. & $\begin{array}{l}0 / 2 \\
\text { (P1tting on } 0 . d \text {. } \\
\text { of } 1 \text { sample) }\end{array}$ \\
\hline & Sensitized & $0 / 1$ & $0 / 1$ & $0 / 1$ & $\begin{array}{l}1 / 2 \\
65 \mu\end{array}$ \\
\hline
\end{tabular}

a) The composition of test solution changes substantially with time.

b) Not examined (N.E.)

c) Specimens with microcracks/number of specimens examined.

d) Maximum crack length in $\mu$. 
Table 3.14 Stress Corrosion Cracking Tests For Incoloy 825. (Abraham-1986)

\begin{tabular}{|c|c|c|c|c|c|}
\hline \multirow{2}{*}{$\begin{array}{r}\text { Test Time } \\
\text { (Montha) }\end{array}$} & \multirow{2}{*}{$\begin{array}{l}\text { Specimen } \\
\text { Conditions }\end{array}$} & \multicolumn{2}{|c|}{ Steam Test } & \multicolumn{2}{|c|}{$\begin{array}{l}\text { Water Teat } \\
\end{array}$} \\
\hline & & J-13 Water & $10 \times J-13$ Water ${ }^{\mathrm{a}}$ & $\mathrm{J}-13$ Water $^{\mathbf{a}}$ & $10 \times J-13$ Water ${ }^{8}$ \\
\hline \multirow{2}{*}{3} & As Recelved & N.E. B & N.E. & N.E. & N.E. \\
\hline & Sensitized & N.E. & N.B. & N.E. & N.E. \\
\hline \multirow{2}{*}{6} & As Recelved & N.E. & $\begin{array}{l}1 / 1^{c} \\
40_{\mu}^{d}\end{array}$ & N.E. & $0 / 2$ \\
\hline & Sensitized & N.E. & $0 / 2$ & N.E. & $0 / 2$ \\
\hline \multirow{2}{*}{12} & As Recelved & N.E. & $0 / 1$ & N.E. & $0 / 1$ \\
\hline & Sensitized & N.E. & $0 / 1$ & $0 / 1$ & $0 / 1$ \\
\hline
\end{tabular}

a) The composition of test solution changes substantially with time.

b) Not examined (N.E.)

c) Specimens with mlcrocracks/number of specimens examined.

d) Maximum crack length in $\mu$. 
Table 3.15 Composition of J-13 And 10x J-13 Solution During Stress Corrosion Experiments. (Abraham-1986)

\begin{tabular}{|c|c|c|c|c|c|c|c|c|c|c|c|c|c|c|c|c|c|c|c|}
\hline & \multirow{2}{*}{\multicolumn{5}{|c|}{ 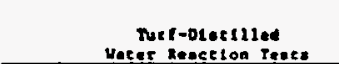 }} & \multicolumn{5}{|c|}{ Three Moath reat } & \multicolumn{4}{|c|}{ S1 I Month Teat } & \multicolumn{5}{|c|}{ Twivo Noneth Toue } \\
\hline & & & & & & \multicolumn{2}{|c|}{$\begin{array}{l}\text { Syncheclic } \\
j-i j \text { Yotor }\end{array}$} & \multicolumn{3}{|c|}{$10 x \mathrm{~J}-13$ water } & \multicolumn{2}{|c|}{$\begin{array}{l}\text { Synthatie } \\
3-13 \text { Hoter }\end{array}$} & \multicolumn{2}{|c|}{ [0x $J-\{\}$ Yater } & \multicolumn{2}{|c|}{$\begin{array}{l}\text { 37othetie } \\
J-13 \text { Heter }\end{array}$} & \multicolumn{3}{|c|}{ 10. $J-\{\}$ Yoter } \\
\hline & (E) & $\begin{array}{l}(b) \\
12(c)\end{array}$ & (i) & (e) & $\begin{array}{l}(0) \\
117\end{array}$ & (n) & $\begin{array}{l}7(h) \\
116\end{array}$ & (10) & in & iin & $\begin{array}{l}\text { (8) } \\
113\end{array}$ & (n) & (Bi) & $\begin{array}{l}\text { (n) } \\
112\end{array}$ & (ह) & (s) & $(3)$ & (in) & (ग) \\
\hline $\mathrm{Met}^{+}$ & 45 & 308 & 190 & 42 & 167 & - & - & 861 & 420 & 960 & 464 & 217 & 738 & 338 & 510 & 200 & 908 & 472 & \$97 \\
\hline$x^{+}$ & 4.9 & 90.5 & 21 & 2.0 & 13.2 & 238 & 1.13 & 264 & iss & 2ss & 264 & 113 & 216 & 91.1 & 106 & .64 .0 & 139 & 60.5 . & 03.0 \\
\hline $\cos ^{24}$ & 14 & 130 & 290 & 122 & 132 & 308 & 1.51 & 301 & 161 & 332 & 161 & 68.5 & 164 & 67.5 & 304 & 46.4 & 129 & 4. & is \\
\hline $3 x^{24}$ & - & - & - & - & 1.2 & 3.4 & 8.0 & 4.4 & 2.2 & 4.2 & 0.4 & 0.2 & 0.5 & co.t & 1.0 & 0.5 & 1.2 & 0.5 & 1.7 \\
\hline $\boldsymbol{r}$ & 2.2 & 0.5 & $<$ & 2 & 2 & 12.1 & $n .1$ & 16 & 8.9 & 15 & 4 & 3 & s & 3 & 6.3 & 2.0 & 21.1 & 4.6 & 9.3 \\
\hline $\mathrm{cl}^{-}$ & 7.5 & 160 & 43.7 & 23.2 & 21.2 & 130 & 72 & 330 & 160 & 330 & 236 & 111 & 211 & 106 & 161 & 80 & 260 & 108 & 2ss \\
\hline wo,- & 5.6 & 460 & 188 & 36 & 53 & 460 & :134 & - & - & - & 790 & 354 & 522 & 268 & 482 & 267 & 672 & 339 & 460 \\
\hline so, $2-$ & 22 & 343 & 330 & 247 & 267 & 820 & 1,20 & 1300 & 660 & 1300 & 352 & 282 & 1260 & 356 & 588 & 298 & 976 & 469 & 964 \\
\hline $\mathrm{sio}_{2}$ & 61 & 95.1 & 142 & 214 & 231 & 414 & a9 & 108 & 205 & 621 & 431 & 210 & 4s8 & 267 & 458 & 276 & 406 & 216 & 200 \\
\hline pil $\left(20^{\circ} \mathrm{C}\right)$ & 8.5 & 6.4 & 8.3 & 9.0 & & & & & & 0.6 & 9.0 & & 8.9 & & 9.3 & & 9.3 & & \\
\hline pil $\left(100^{\circ} \mathrm{C}\right)$ & & & 7.6 & 6.5 & 9.6 & & & & & 7.7 & 8.3 & & 8.3 & & 0.5 & & 0.6 & & \\
\hline
\end{tabular}

LECEND

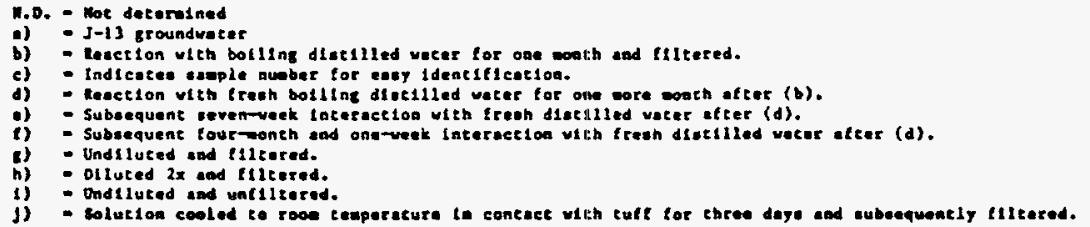


Table 3.16 Actual Analyses of Copper Alloys Used In Corrosion Tests. (McCr Ight-1985)

\begin{tabular}{|c|c|c|c|c|c|c|c|c|}
\hline \multicolumn{9}{|c|}{ Elemental compositions (wty) } \\
\hline Alloy & $\overline{\mathrm{Cu}}$ & $N 1$ & AI & $M_{n}$ & Sn & $\mathrm{Fe}$ & $2 n$ & Other \\
\hline \multirow[t]{3}{*}{ CDA 102} & 99.95 & - & - & - & - & - & $<0.001$ & $P b<0.001 ; C d<0.001$ \\
\hline & & & & & & & & $\mathrm{S}<0.0018 ; \mathrm{Hg}<0.0001$ \\
\hline & & & & & & & & $P<0.003$ \\
\hline CDA 673 & 90.82 & 0.05 & 6.75 & 0.16 & 0.20 & 2.46 & 0.01 & $\mathrm{~Pb}<0.01 ; \mathrm{Co}<0.01$ \\
\hline \multirow[t]{2}{*}{ COA 715} & 69.18 & 29.60 & - & 0.51 & - & 0.53 & 0.07 & $P b-0.01 ; P-0.002 ;$ \\
\hline & & & & & & & & $C-0.04 ; S-0.01$ \\
\hline
\end{tabular}


Table 3.17 General Corroslon Penetrat Ion Rates of Candidate CopperBase Materlals And Other Materlals. For Comparison, in

Tuff ReposItory EnvIronmental Conditlons. (McCrIght-1985)

General corrosion rates $(m i 1 s / y)$

Alloy

$80^{\circ} \mathrm{C} \mathrm{J}-13$

$100^{\circ} \mathrm{C} \mathrm{J}-13$

Wet steam

$100^{\circ} \mathrm{C}$

Dry steam

$(3336 \mathrm{~h})$

$(6000 \mathrm{~h})$

$(6000 \mathrm{~h})$

$150^{\circ} \mathrm{C}$

CDA 102

0.127

0.083

0.124

0.061

CDA 613

0.172

0.059

0.090

0.014

CDA $\quad 715$

0.033

0.040

0.014

0.002

CDA $\quad 110$

0.159

$-\cdots$

$-\cdots$

0.099

CDA 706

0.016

$---$

$---$

Mone 1400 
the other hand, CDA 715 exhlblted lower rates in wet steam than in J-13 water at $100^{\circ} \mathrm{C}$. For all test environments, corrosion rates were lower for CDA 715 than for the other two candidate alloys. It is also interesting to note that Monel 400 exhlbited the lowest rate of corrosion in the single test $\left(\mathrm{J}-13\right.$ water at $\left.80^{\circ} \mathrm{C}\right)$. This suggests that the $\mathrm{NI}$ addltions in CDA 715 and Monel Alloy 400 are beneficlal to general corrosion resistance in thls environment. The hlghest corrosion rate observed in the tests was $0.172 \mathrm{mlls} /$ year (for CDA613 in J-13 well water at $80^{\circ} \mathrm{C}$ ) a rate corresponding to only 0.172 inches lost in 1,000 years.

McCright-1985 also performed electrochemical corrosion studies of the candidate copper base alloys in $\mathrm{J}-13$ well water. Potentlodynamic polarization curves were used to evaluate the susceptibllity of the materlals to general and localized forms of corrosion. The experiments were performed at 23 to $80^{\circ} \mathrm{C}$ in naturally aerated well water at a scan rate of $1 \mathrm{mV} / \mathrm{s}$. A typlcal polarization curve is shown in Flgure 3.8 (McCrlght-1985). The parameters of interest with regard to general corrosion are I cor and I pas. lcor is the corrosion rate at the free-corrosion potential of the small coupon and is determined by a Tafel extrapolation technique. Ipas is the passive current density and this value is of interest since the corrosion potential of a material in service may be different than that of a small coupon. Since passive currents generally decrease with time, Ipas usually represents an upper bound for the corrosion rate over the potentlal range In which the materlal is passive. See Appendlx A for additional information on electrochemical techniques for corrosion evaluation.

FIgures 3.9 and 3.10 (MCCright-1985) are summaries of the Ipas and I cor respectively for the three alloys in $\mathrm{J}-13$ well water at 25 to $80^{\circ} \mathrm{C}$. The data in Figure 3.10 were converted to corrosion rates by means of Faradays law. $10 u A / \mathrm{cm}^{2}=9.14 \mathrm{mpy}$ for pure copper and a valence change of +1 ( $\mathrm{Cu}$ $\rightarrow \mathrm{Cu}^{+}+e^{-}$). Figure 3.10 shows that corrosion rates ( $I_{\text {cor values) were }}$ similar for the three alloys and there were no systematic trends in corrosion rates with increasing temperature; In the unconcentrated $\mathrm{J}-13$ water, the lpas values shown in Flgure 3.9 were generally larger than related l cor values and tended to Increase with Increasing temperature. Values for CDA 715 were slightly lower than those of the other two alloys. Finally, general corrosion rates for elther technique were conservative when compared with rates estimated from welght loss.

\subsubsection{Locallzed Corrosion}

McCright-1985 evaluated the locallzed corrosion behavior of three candidate copper base alloys, CDA 102, CDA 613 and CDA 715 in J-13 well water at temperatures between 23 and $80^{\circ} \mathrm{C}$. Potentlodynamic polarization experiments were performed at a scan rate of $1 \mathrm{mV} / \mathrm{sec}$ under naturally aerated conditlons. Values of $E_{p l t}$ were compared with $E_{\text {cor }}$ values to estimate pitting propenslty for the materlals. See Appendix A for additional detalis on electrochemical technlques. Classical passivepltting behavior was observed for many of the test conditlons. A typlcal curve is shown in Flgure 3.11 (McCright-1985). A summary of their measurements is given in Figures 3.12-3.14 (McCrlght-1985). Figure 3.13 shows that there was a slight trend of Increasing values of $E_{p l t}$ with Increasing temperature and values for the three alloys were comparable. FIgure 3.14 shows that the difference between $E_{p l t}$ and $E_{c o r}$ was positive and was between 100 and $200 \mathrm{mV}$ for the three alloys. 


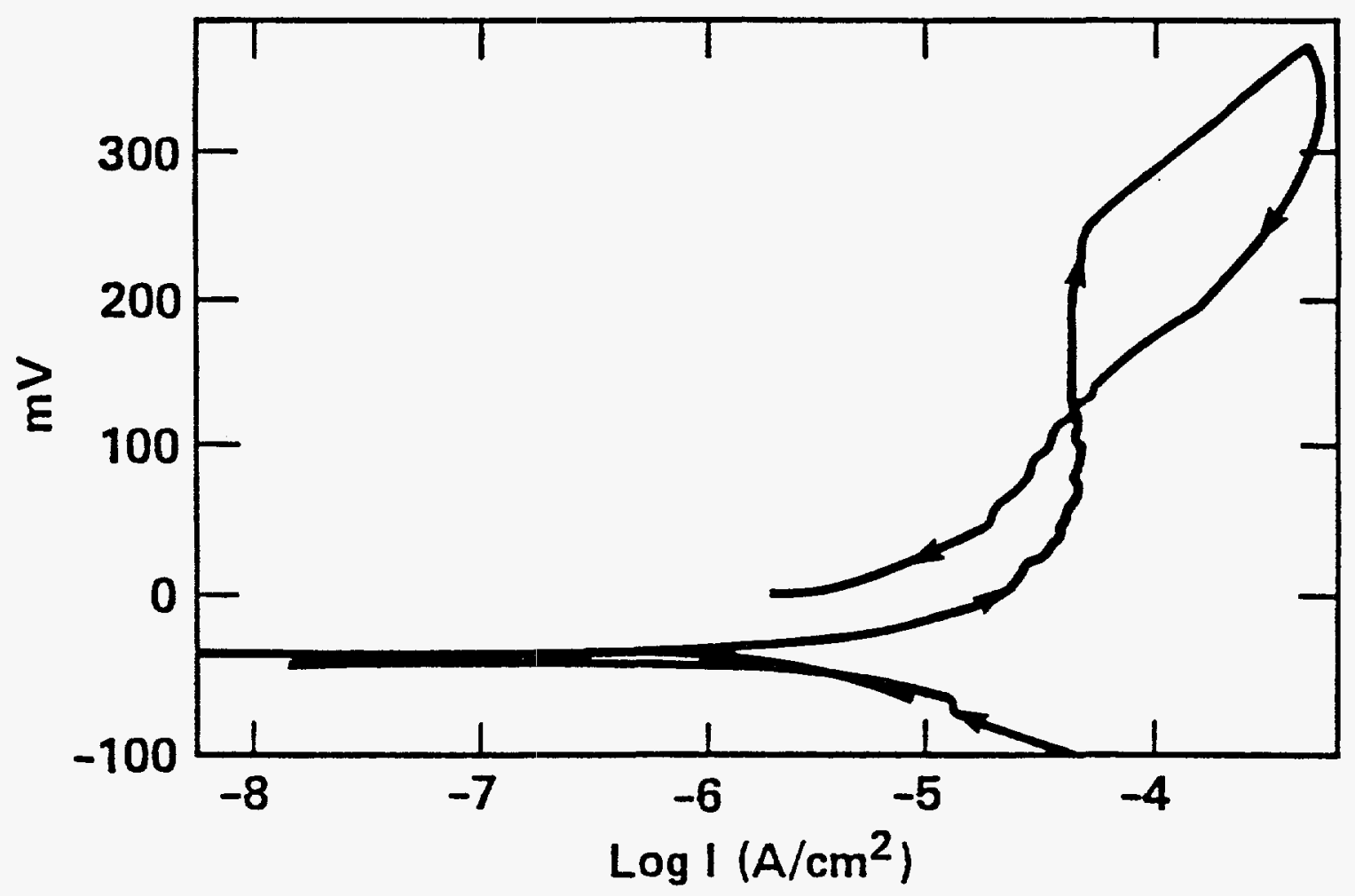

Figure 3.8 Polarization Behavior of CDA 613 in $J-13$ Water At $80^{\circ} \mathrm{C}$. (McCr Ight-1985) 


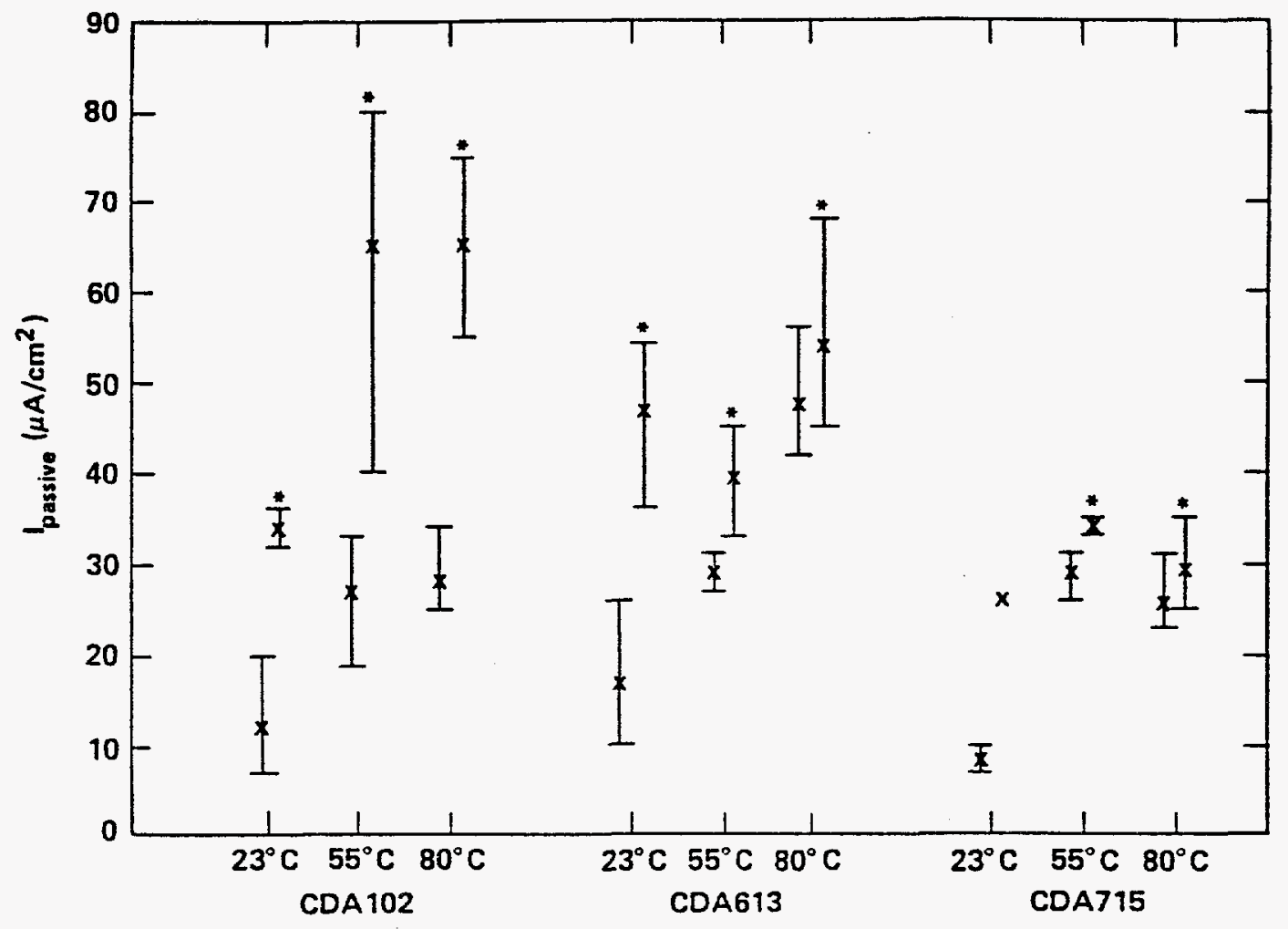

Figure 3.9 Values of The Passive State Current Density For J-13 And $100 \times$ Concentrated $\mathrm{J}-13$ At DIfferent Temperatures.

* $100 \times \mathrm{J}-13$. (MCCright-1985) 


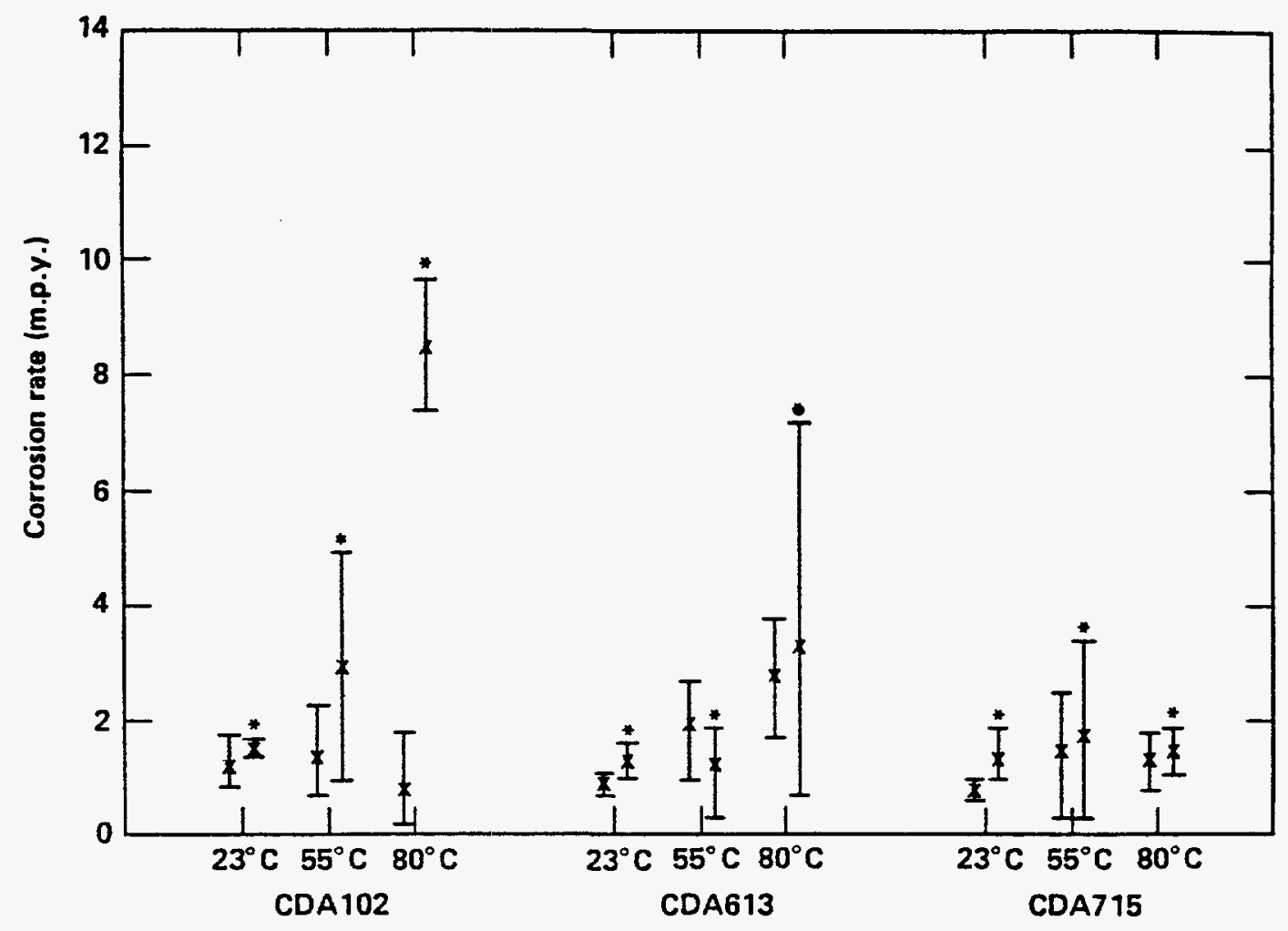

Figure 3.10 Corrosion Rates in J-13 And 100x Concentrated J-13 As A Function of Temperature. $-100 \times \mathrm{J}-13$. (MCCrlght-1985) 


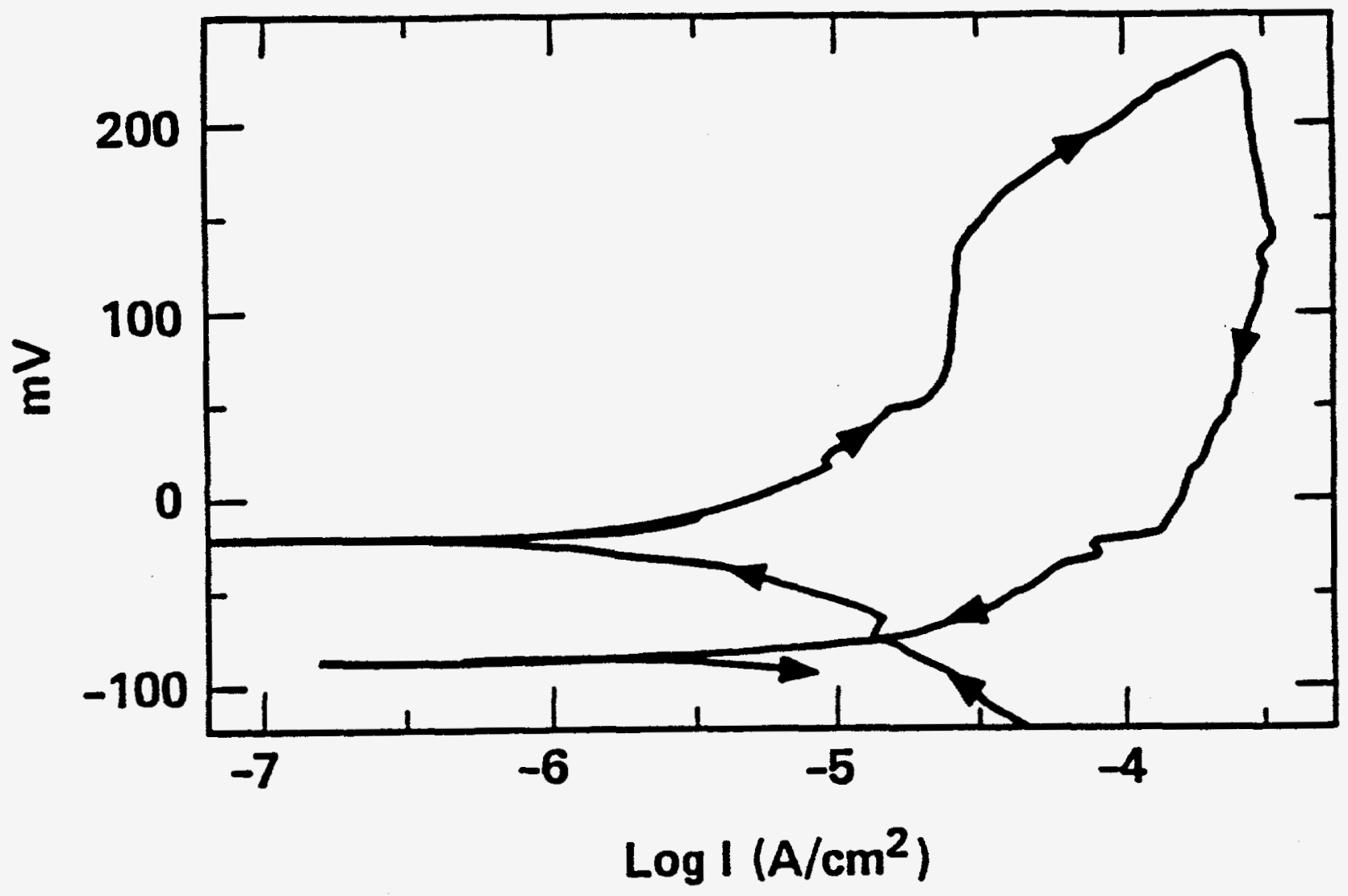

Flgure 3.11 Polarization behavior of $\operatorname{COA} 715$ in $\mathrm{J}-13$ water At $80^{\circ} \mathrm{C}$. (McCr Ight-1985) 


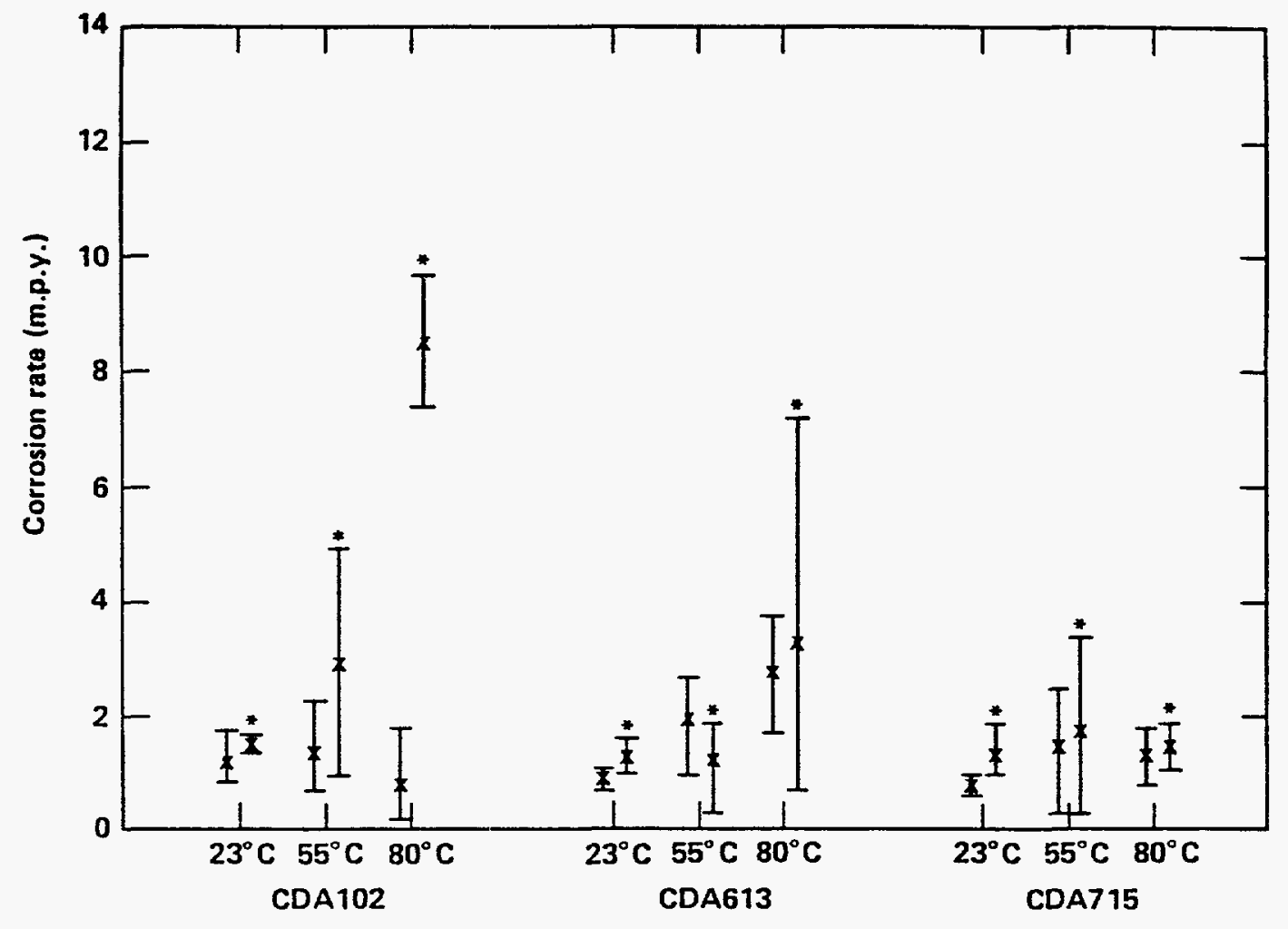

Figure 3.12 Corrosion Potentlals in $\mathrm{J}-13$ And $100 \times$ Concentrated $\mathrm{J}-13$ At Different Temperatures. $-100 \times \mathrm{J}-13$. (McCrlght-1985) 


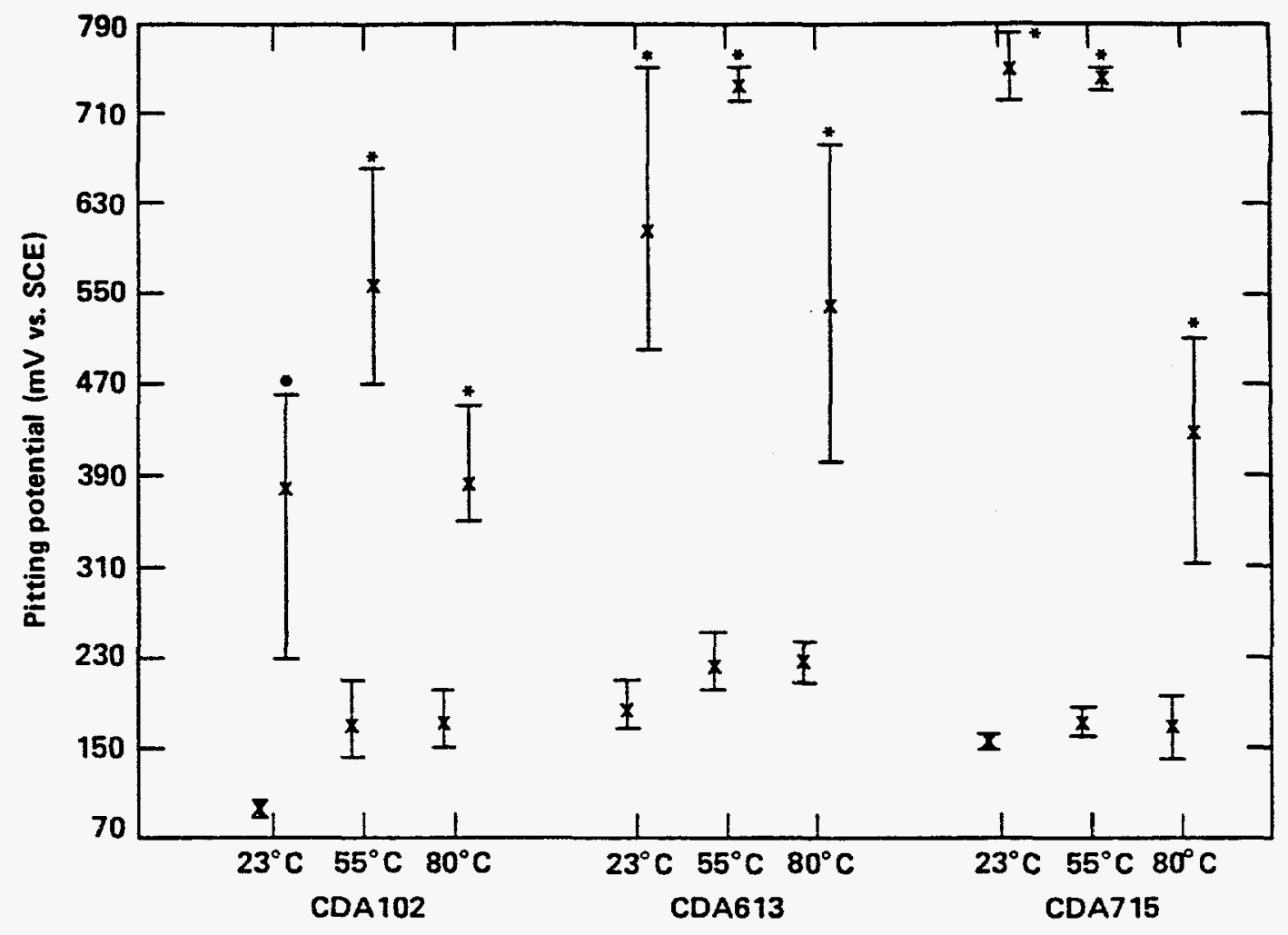

Flgure 3.13 Pltting Potentlals in $\mathrm{J}-13$ and $100 x$ Concentrated $\mathrm{J}-13$ At Different Temperatures. $-+100 \times \mathrm{J}-13$. (McCright-1985) 


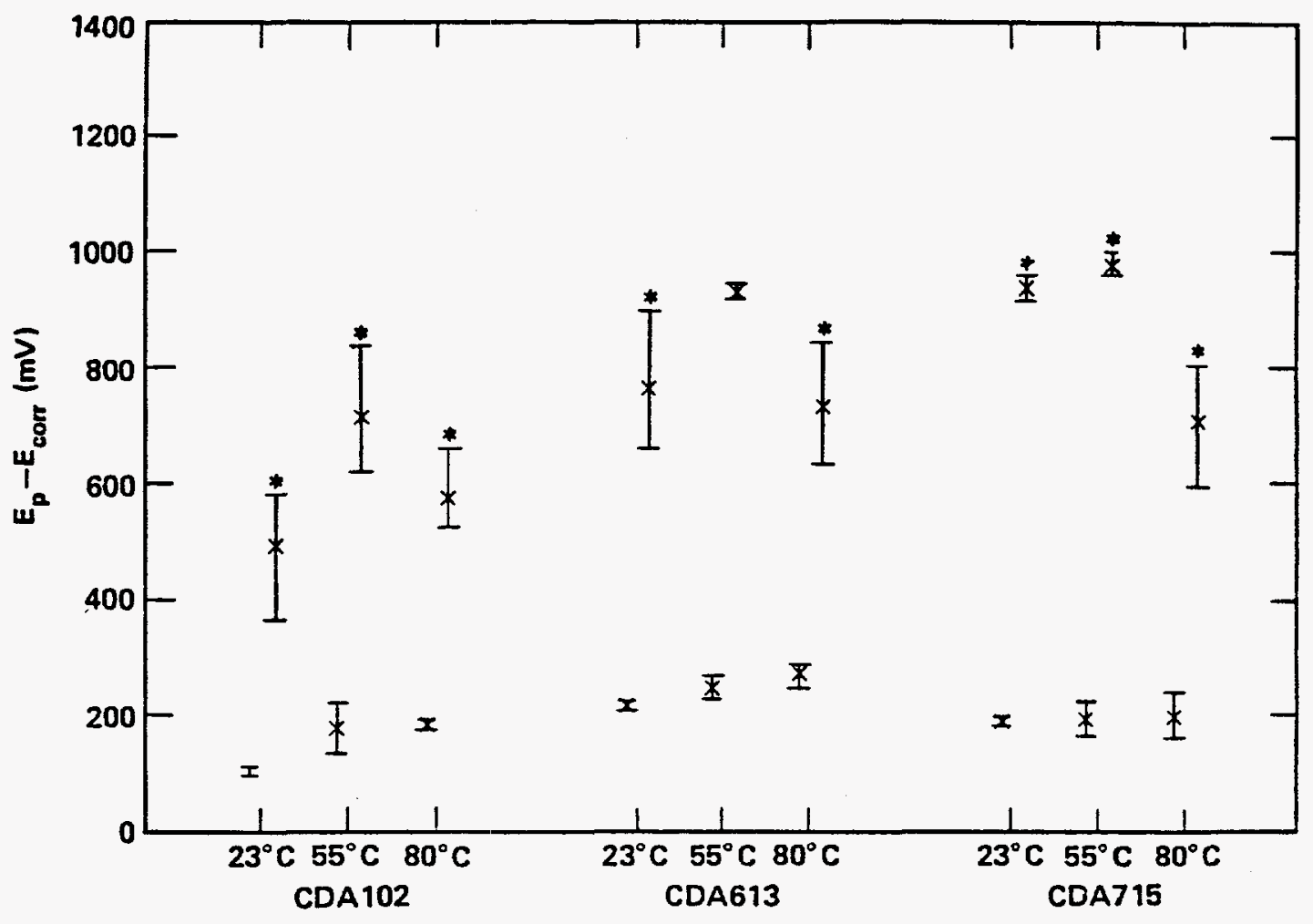

Figure 3.14 Values For Separation of Pitting And Corrosion Potentlals In J-13 And 100x Concentrated J-13 At Different Temperatures. - $=100 \times \mathrm{J}-13$. (MCCr lght-1985) 
Curlously, the authors did not report protection potentlals, which are potentlal values below which propagating plts will repassivate. In general, when Ecor is more positive than Eprot, localized corrosion is highly likely in that, once inltlated, It will not stop propagating. In addition, Eplt generally tends to decrease with scan rate and may approach Eprot depending on the alloy system (Broll-1977). It is certaln that the assessment of the pltting performance of the copper base alloys would have been less optimistic had an evaluation of $E_{p r o t}$ been performed. For example, Figure 3.11 shows that CDA 715 had an $E_{p l t}$ value of about $140 \mathrm{mV}$ and an $E_{\text {cor }}$ value of about $25 \mathrm{mV}$, giving an $E_{p / t}-E_{\text {cor }}$ value of $+165 \mathrm{mV}$ in $\mathrm{J}-13$ well water at $80^{\circ} \mathrm{C}$. On the other hand, the Eprot value was about $-80 \mathrm{mV}$ giving an $E_{p r o t}{ }^{-E}$ cor value of $-55 \mathrm{mV}$. Thus localized corrosion for this alloy - environmental system is probable.

Results of recent research performed at Cortest Columbus (Beavers-1988) Indlcate that great care should be taken in Interpreting the results of electrochemlcal studles performed on the copper base alloys in Tuff environments. On CDA 102 copper, two distinct types of corrosion processes have been assoclated with essentlally identical polarlzation curves. In several simulated groundwaters, potentlodynamic polarization curves similar to Figure 3.11 have been obtained. In one environment, the hysteresis on the reverse scan was correlated with classlcal pltting. However, In several other environments, the hysteresis was assoclated with reglons of passive film color change on the specimen, without apparent increases in rates of attack. This color change may be assoclated with a change in oxidation state of the flim (e.g. from $\mathrm{Cu}^{+}$to $\mathrm{Cu}^{+2}$ ) and/or may represent the early stages of $111 \mathrm{~m}$ breakdown. Future research is planned to Investigate this phenomenon.

\subsubsection{Stress Corrosion Cracking (SCC)}

Data in the literature on stress corrosion cracking of copper base alloys in J-13 well water (in the absence of a radlation field) were not found. Results of exposures of CDA 102, CDA 613 and CDA 715 in Irradiated J-13 well water and the vapors above those waters are descrlbed by Yunker-1986a and Acton-1986. No stress corrosion crackIng was reported In approximately six months of exposure; for additional detalls, seo section 5.2.3. In splte of the apparent good stress corrosion cracking performance in the above tests, cracking remains as a potentially serlous problem for the copper base alloys. As shown in Table 3.18, historlcally, stress corrosion cracking of copper base alloys has been observed in numerous environments Including sulfates, nitrates, nitrites, ammonla, humld alr and steam. Whlle Cu-Zn alloys predominate in the Table, this may reflect, In part, the fact that the brasses are used extensively and more stress corrosion research has been performed on these alloys than on other alloys. It is generaliy established that pure copper and copper-nickel a lloys are more resistant to stress corrosion cracking than are most other copper base alloys. However, as shown In Table 3.18, these alloys are susceptlble to stress corrosion cracking in several of the reported cracking environments. 


\section{Table 3.18 Summary of Environments Known To Promote Stress Corrosion Cracking of Copper Base Alloys}

\section{Environment}

Ammon la

Nitrites

Steam

Steam

Ammon la

Room Temperature

Humld Alr

$\mathrm{SO}_{4}$

Nitrates

$\mathrm{ClO}_{3}^{-}$
Alloy

Pure Copper, $\mathrm{Cu}-\mathrm{Ni}$

Pure Copper

Al Bronze

$\mathrm{Cu}-\mathrm{NI}$

Al Brass

Cu-Zn Alloys

Cu-Zn Alloys

$c u-z n$

$c u-z n$
Reference

Thompson-1944

Ben Jam in-1983

Klement -1959

Sato-1974a

Sato-1974a

Sato-1974b

Kawash Ima-1979

Graf-1969

Kawash Ima-1977 


\section{THERMAL EFFECTS ON CORROSION}

\subsection{Fe-Cr-NI Alloys}

\subsubsection{General Corrosion}

Glass-1984 evaluated the Influence of temperature on the general corrosion rates, calculated from welght loss, of several candidate contalner materlals in alr saturated $\mathrm{J}-13$ well water. The results, summarized in Table 4.1 (Glass-1984) do not Indlcate any signiflcant effects of temperature on the corrosion rates over the temperature range of 50 to $100^{\circ} \mathrm{C}$. All of the general corrosion rates reported are quite low.

An electrochemical technlque, Tafel extrapolation, also was used to evaluate the temperature dependence of the general corrosion rates of the alloys in aerated J-13 well water (Glass-1984). This technlque is used in conjunction with potentlodynamic polarization experiments. See Appendix A. Results, summarlzed in Figure 4.1 (Glass-1984) Indlcate trends of Increasing corrosion rate with increasing temperature for most of the al loys evaluated. The absolute values of the corrosion rates also are somewhat higher than those calculated from welght loss. The latter behavlor is not uncommon but the welght loss data are generally considered to glve more rellable general corrosion rates.

Glass-1984 evaluated the influence of $\mathrm{Cl}$ concentration of $\mathrm{J}-13$ well water on general corrosion rates of Type 304L stalnless steel determined by two electrochemical techniques, Tafel extrapolation and polarization resistance. $\mathrm{NaCl}$ was added to the well water to simulate thermal concentratlon of deleterlous specles in the groundwater. Results summarized in Figure 4.2 (Glass-1984) show that general corrosion rates increased 5-10 fold at $\mathrm{Cl}$ concentration above $1000 \mathrm{ppm} \mathrm{Cl}$, which represents a concentration of groundwater of about 100 . It should be noted that this test is probably unreallstically accelerated since, under thermal concentration, beneficlal as well as detrimental specles would be expected to be concentrated.

\subsubsection{Locallzed Corrosion}

Glass-1984 and McCright-1984 evaluated the Influence of temperature on the electrochemical pltting parameters for several candidate alloys in $\mathrm{J}-13$ well water. Cyclic anodlc polarization curves were obtalned on $304 \mathrm{~L}$ stainless steel, $316 \mathrm{~L}$ stainless steol, Type 321 stalnless steel and incoloy Alloy 825 in $\mathrm{J}-13$ water at $50-100^{\circ} \mathrm{C}$. The exper Iments were performed at a scan rate of $1 \mathrm{mV} / \mathrm{sec}$ under naturally aerated condltions; no at tempt was made to deaerate the J-13 water but the water was not sparged with alr.

$E_{\text {cor and }} E_{\text {prot }}$ as a function of temperature for these alloys are given in Figures 4.3-4.6 (McCright-1984). As descr Ibed in Appendix A, the IIkelihood of pltting corrosion increases as the difference between the two parameters decreases. The data In Figures 4.3-4.6 show that both $E_{p r o t}$

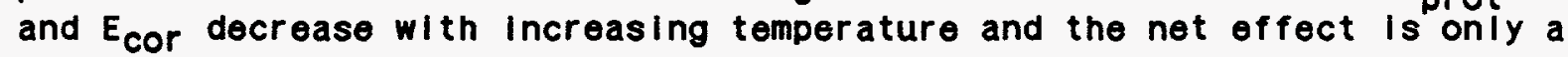
slight decrease in the value of $E_{\text {prot }}-E_{\text {cor with increasing temperature }}$ over the range of $50-100^{\circ} \mathrm{C}$. Thus, over this temperature range, there is only a slight increase in pltting susceptlbility, based on the electrochemIcal data. 
Table 4.1 Corrosion Rates of Candldate Stalnless Steels In J-13 Water As Determined From Melght-Loss Data. (Glass-1984)

\begin{tabular}{|c|c|c|c|c|c|c|}
\hline \multirow[b]{2}{*}{ Alloy } & \multirow{2}{*}{$\begin{array}{l}\text { Test Duration } \\
\text { (hours) }\end{array}$} & \multicolumn{4}{|c|}{$\begin{array}{c}\text { Corroston Rate, mpy } \\
\text { Temperature }\left({ }^{\circ} \mathrm{C}\right)\end{array}$} & \multirow[b]{2}{*}{100} \\
\hline & & 50 & 70 & 80 & 90 & \\
\hline \multirow[t]{2}{*}{ 304L } & 3548 & 0.001 & 0.008 & 0.008 & 0.006 & 0.004 \\
\hline & 5000 & 0.009 & 0.008 & 0.009 & 0.006 & 0.005 \\
\hline \multirow[t]{2}{*}{$316 L$} & 3548 & 0.009 & 0.010 & 0.011 & 0.006 & 0.007 \\
\hline & 5000 & 0.004 & 0.009 & 0.010 & 0.010 & 0.008 \\
\hline \multirow[t]{2}{*}{$317 L$} & 3548 & 0.014 & 0.011 & 0.011 & 0.007 & 0.003 \\
\hline & 5000 & 0.001 & 0.010 & 0.008 & 0.011 & 0.004 \\
\hline \multirow[t]{2}{*}{321} & 3548 & 0.007 & 0.012 & 0.008 & 0.008 & 0.008 \\
\hline & 5000 & 0.005 & 0.011 & 0.008 & 0.013 & 0.001 \\
\hline \multirow[t]{2}{*}{347} & 3548 & 0.009 & 0.015 & 0.010 & 0.008 & 0.010 \\
\hline & 5000 & 0.011 & 0.013 & 0.010 & 0.011 & 0.042 \\
\hline \multirow[t]{2}{*}{$I-825$} & 3548 & $0.0 i 2$ & 0.011 & 0.007 & 0.008 & 0.006 \\
\hline & 5000 & 0.015 & 0.009 & 0.008 & 0.011 & 0.011 \\
\hline
\end{tabular}




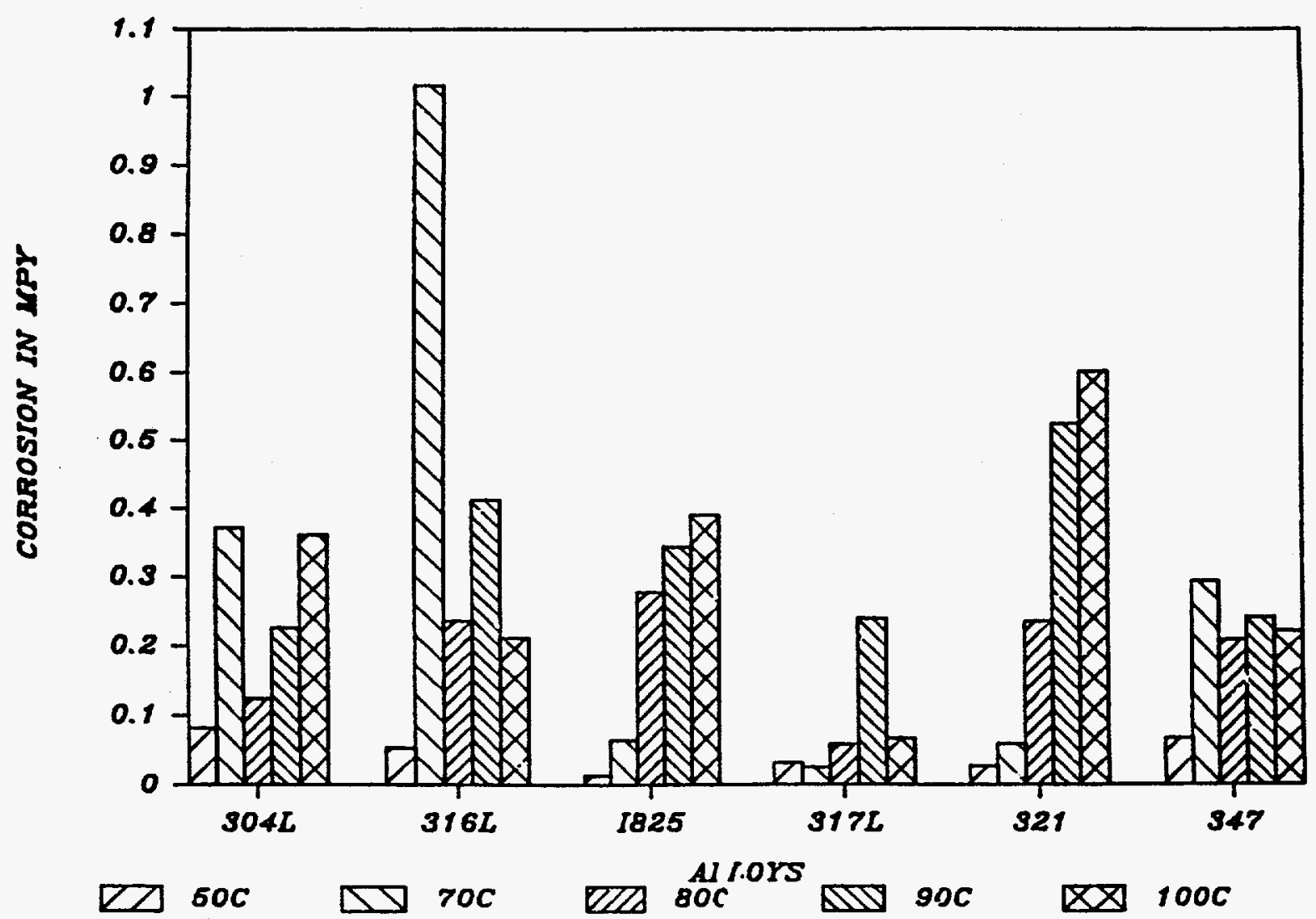

FIgure 4.1 Corrosion Rates For Candldate Alloys In Tuff-Conditioned J-13 Well Water At Different Temperatures. The Tafel Extrapolation Method Was Used. (GIass-1984) 


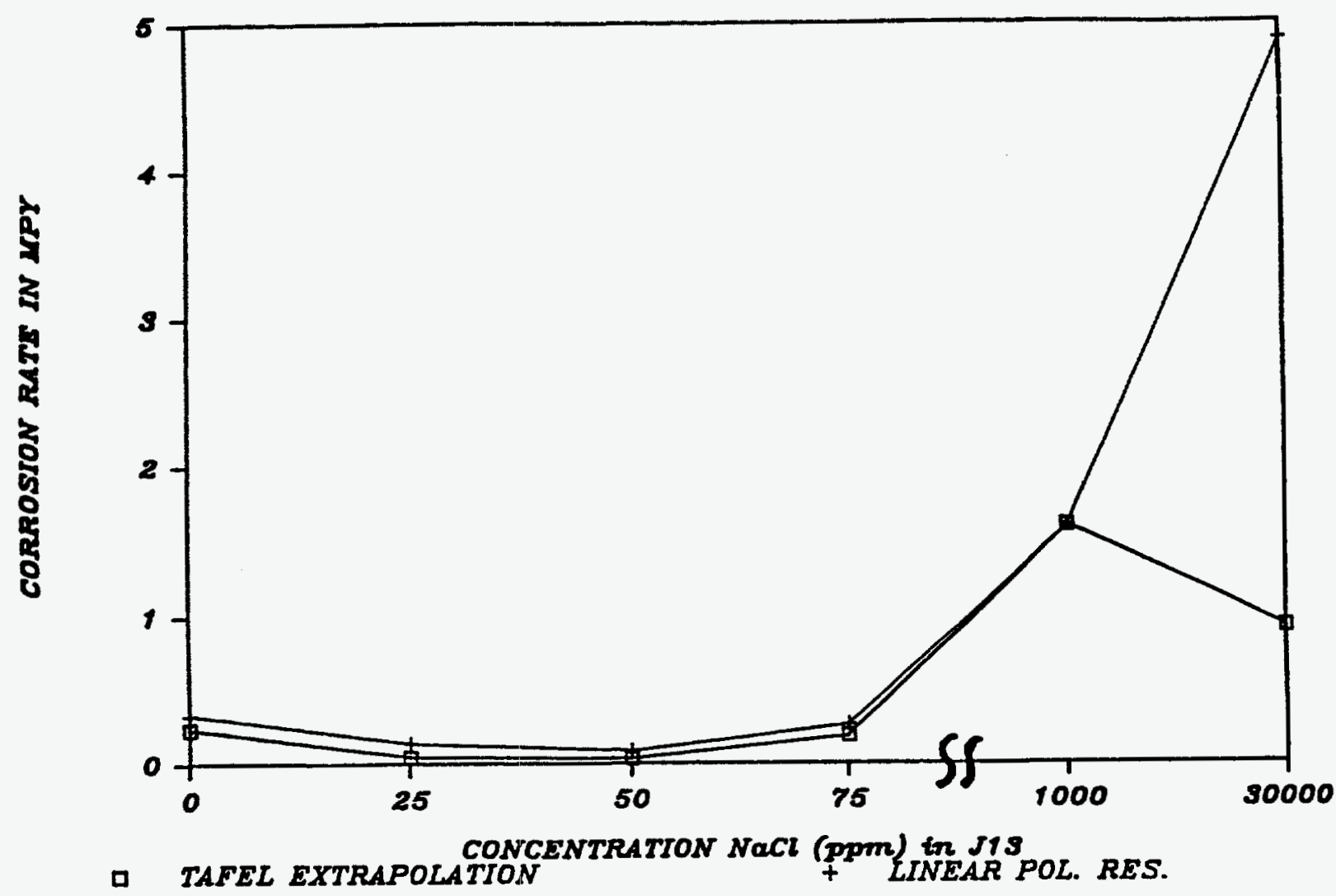

FIgure 4.2 Electrochemical Corroslon Rates For 304L In Tuff-conditloned J-13 Well Water At $90^{\circ} \mathrm{C}$ WIth Different Concentratlons of Addod $\mathrm{NaCl}$. (GIass-1984) 


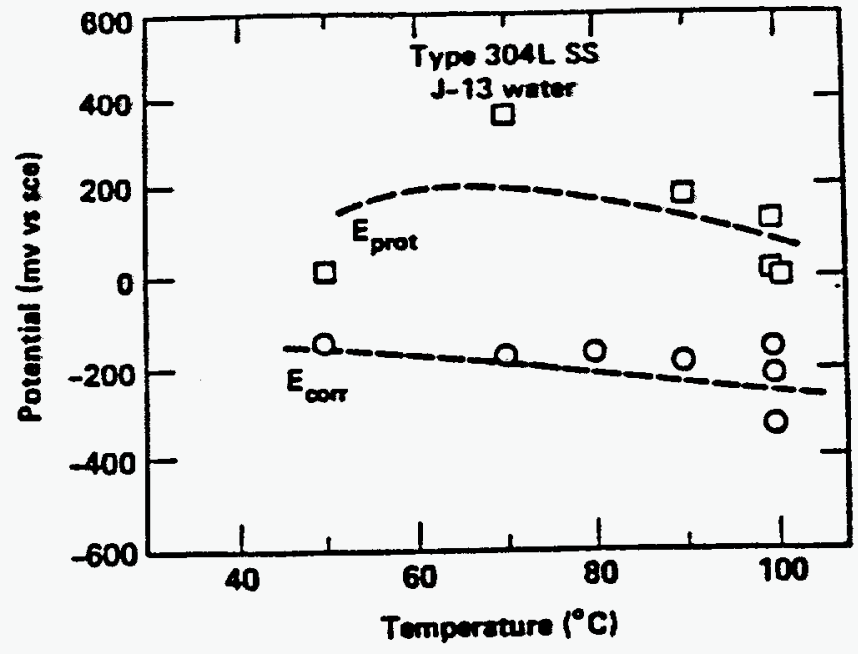

Figure 4.3 Corrosion Potentials And Protection Potentlals For $304 \mathrm{~L}$ Stalnless Steel In Tuff-Conditloned $\mathrm{J}-13$ Water At Different Temperatures. (MCCrlght-1984)

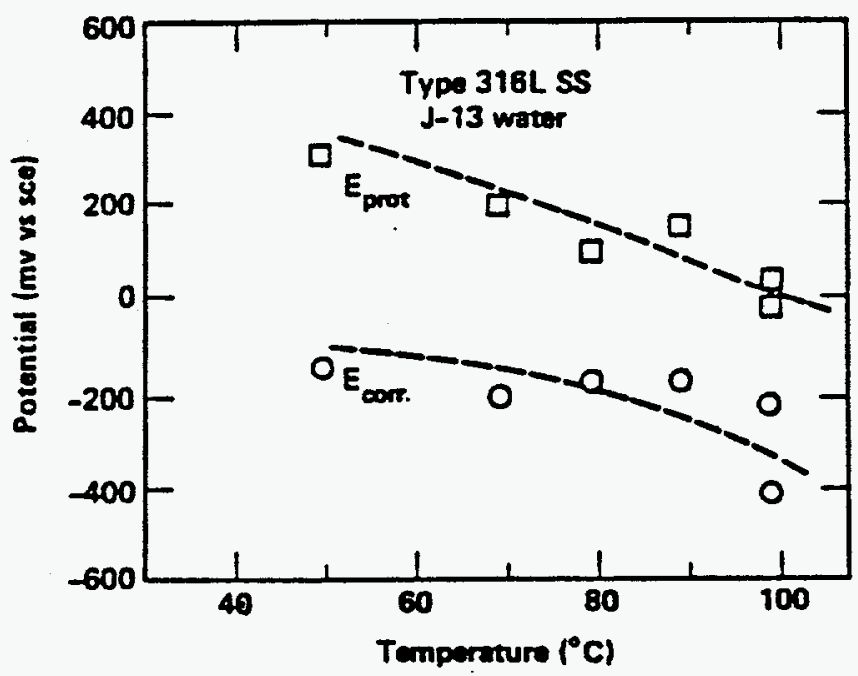

Flgure 4.4 Corrosion Potentlals And Protection Potentlals For 316L Stainless Steol In Tuff-Conditloned J-13 water At Different Temperatures. (McCr lght-1984) 


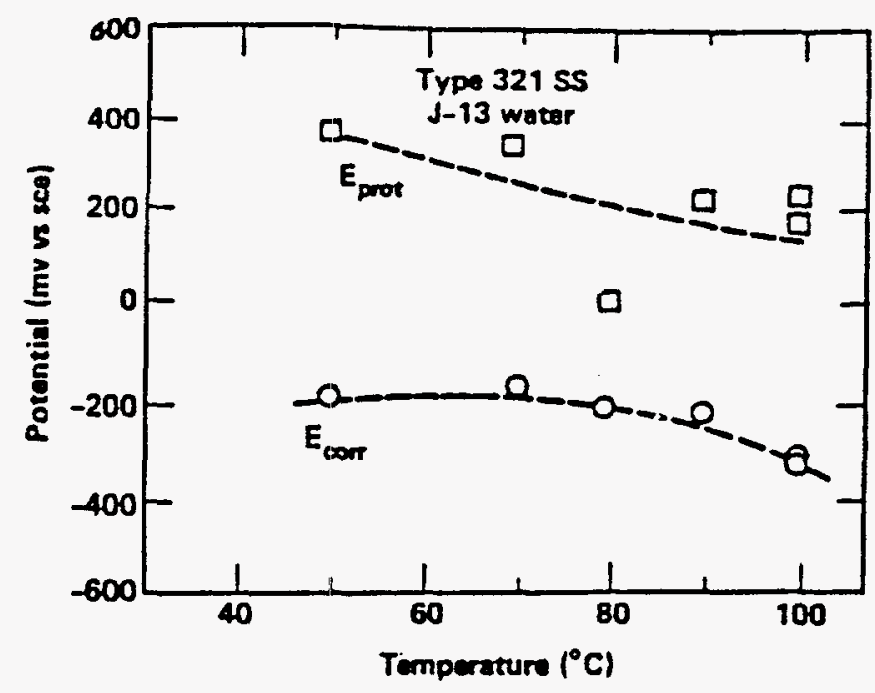

FIgure 4.5 Corrosion Potentlals And Protection Potentlals For 321 Stainless Steel in Tuff-Condltioned J-13 Water At Different Temperatures. (McCrlght-1984)

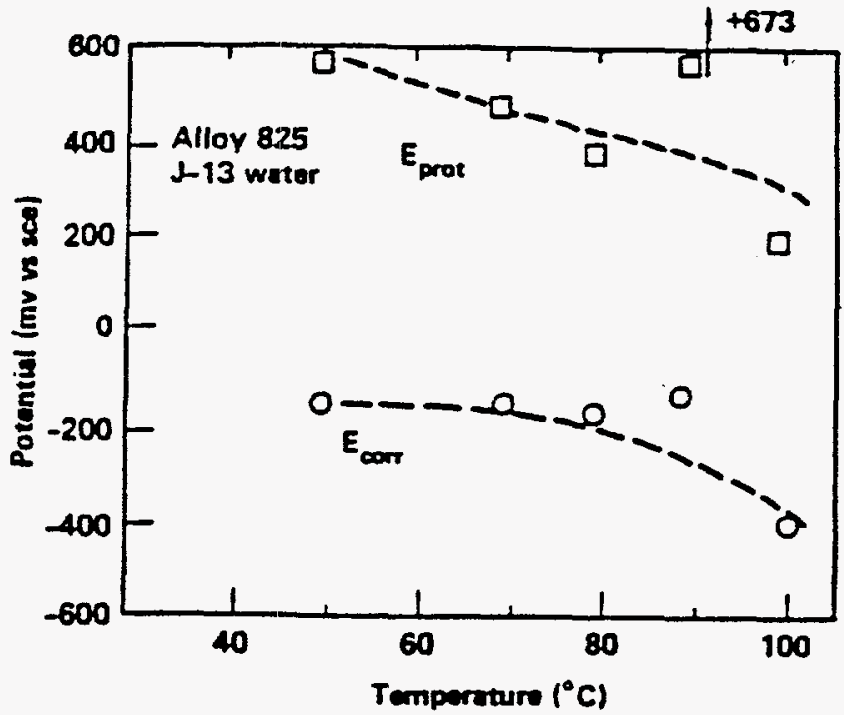

Figure 4.6 Corrosion Potentials and Protection Potentlals For Alloy 825 In Tuff-Condltloned J-13 Water. At Different Temperatures. (McCrIght-1984) 
As descrlbed in section 3.1.2, crevice corrosion tests of one year duration were performed on the candldate alloys (Type 304L stainless steel. Type $316 \mathrm{~L}$ stainless steel, Type 321 stalnless steel, Type 347 stainless steel and Alloy 825 ) in aerated $J-13$ well water over the temperature range of 50 to $100^{\circ} \mathrm{C}$ (Glass-1984). Crevlces were formed by sandwlching flat metal specimens between rlbbed Teflon washers. All of the alloys examined showed some minor crevice attack (described as staining) and there was no apparent temperature dependence of the attack.

\subsection{3 stress Corrosion Cracking}

Pitman-1986 performed groundwater boll-down tests on U-bend specimens of Type 304 and Type $304 \mathrm{~L}$ stalnless steel in J-13 well water. The tests were performed in an autoclave fllled with crushed Tuff rock. The autoclave was operated at $200^{\circ} \mathrm{C}$ and $1000 \mathrm{ps} /$ and, once every week, the pressure was reduced and the water was allowed to boll off. After 24 hours of dry operation, the autoclave was refllled with fresh alr sparged $\mathrm{J}-13$ well water. All of the specimens were given a sensitization heat treatment following a solution anneal. The heat treatment used varled, depending on the alloy as shown in Table 4.2 (Pitman-1986).

The first examination was performed after 4 months (15 boll-downs). None of the Type 304L stalnless steel specimens had cracked but 9 of the 10 sensitized Type 304 specimen had falled. The test was terminated after 12 months and 50 boll-downs, with an Intermediate inspection after 6 months. After 12 months, small cracks were noted in the remaining sensitized Type 304 stainless steel specimens but no fallures were observed in any of the Type 304L stainless steel specimens.

Abraham-1986 exposed V-notched C-ring specimens of several $\mathrm{Fe}-\mathrm{Cr}-\mathrm{NI}$ alloys to bolling synthetlc Tuff groundwater and to the steam phase above the bolling solutions. Two test solutions were used; the standard synthetic J-13 well water and a solution prepared to simulate a $10 x$ concentration of that groundwater. ASTiM procedure G-38 was used for the testing. All specimens were in contact with crushed Tuff during the exposures. The test durations were 3,6 and 12 months. Four alloys were evaluated: Type 304L stalnless steel, Type $316 \mathrm{~L}$ stainless steel, Type 321 stainless steel and Incoloy Alloy 825. Their chemical compositions are given in Table 3.9 (Abraham- 1986). Both solutions annealed (SA) and SA plus sens/tized heat treatments were evaluated. The sensitization heat treatment consisted of 100 hours at $600^{\circ} \mathrm{C}$ followed by furnace cooling. The solution annealed condltion was as-recelved. All specimens were stressed at room temperature to $90 \%$ of the elastic limit, calculated for unnotched specimens. The test matrix for the experiments is given in Table 3.10 (Abraham-1986).

Table 4.3 (Abraham-1986) shows chemlcal compositlons of the solutions after 3 months, 6 months and 1 year. It can be seen that both solutions concentrated as a result of the bolling with the or Iginal $10 x$ solution being only slightly more concentrated then the $1 x$ solution after 1 year.

In spite of this concentration of deleterlous specles, only inciplent cracks were found on the specimens. Fine microcracks were detected on specimens of Type 304L stalnless steel, Type 316L stainless steel and Type 321 stainless steel. One specimen of Incoloy Alloy 825 also was found to contain mlcrocracks. These cracks were generally less than $2 \mathrm{mlls}$ (50um) 
Table 4.2 Sensltization Heat Treatments For Bolldown Test. (PItman-1986)

$\begin{array}{clcc}\frac{\text { Stainiess Steel }}{304} & \frac{\text { Sensitization Heat Treatment }}{24 \mathrm{~h} \text { at } 600^{\circ} \mathrm{C} \text {, air cool }} & \text { Number of Soecimens } \\ 304 \mathrm{~L} & 24 \mathrm{~h} \text { at } 550^{\circ} \mathrm{C} \text {, air cool } & 10 \\ 304 \mathrm{~L} & 24 \mathrm{~h} \text { at } 700^{\circ} \mathrm{C} \text {, water quench } & 10 \\ 304 \mathrm{~L} & 8 \mathrm{~h} \text { at } 700^{\circ} \mathrm{C} \text {, water quench } & 10\end{array}$


Tablo 4.3 Chemical composition of Test Solutions At The End of corrosion Tests (ug/mL) (undliluted and flitered solution). (Abraham-1986)

\begin{tabular}{|c|c|c|c|c|c|c|c|}
\hline & \multirow{2}{*}{$\begin{array}{l}\text { Reference } \\
\mathrm{J}-13 \\
\text { Groundwater }\end{array}$} & \multicolumn{3}{|c|}{ Synthetfe J-13 Water } & \multicolumn{3}{|c|}{ 10-Times Conc. J-13 Water } \\
\hline & & $\begin{array}{c}3 \text { - Month } \\
\text { Test }\end{array}$ & $\mid \begin{array}{c}6 \text {-Month } \\
\text { Test }\end{array}$ & $\begin{array}{c}\text { 1-Year } \\
\text { Test }\end{array}$ & $\begin{array}{c}\text { 3-Honth } \\
\text { Test }\end{array}$ & $\begin{array}{c}\text { 6-Honth } \\
\text { Test }\end{array}$ & $\begin{array}{c}\text { 1-Year } \\
\text { Test }\end{array}$ \\
\hline $\mathrm{Na}^{+}$ & 45 & N.D.* & 464 & 510 & 867 & 738 & 908 \\
\hline $\mathrm{x}^{+}$ & 4.9 & 238 & 244 & 106 & 244 & 214 & 139 \\
\hline $\mathrm{Ca}^{2+}$ & 14 & 308 & 161 & 104 & 301 & 164 & 129 \\
\hline $\mathrm{Sn}^{2+}$ & N.D. & 3.4 & 0.4 & 1.0 & 4.4 & 0.5 & 1.2 \\
\hline $\mathbf{F}$ & 2.2 & 12.1 & 4 & 6.31 & 14 & 5 & 21.1 \\
\hline $\mathrm{CI}^{-}$ & 7.5 & 130 & 236 & 161 & 330 & 211 & 260 \\
\hline $\mathrm{NO}_{3}^{-}$ & 5.6 & 460 & 750 & 482 & - & 522 & 672 \\
\hline $\mathrm{SO}_{4}{ }^{2-}$ & 22 & 820 & 552 & 588 & 1300 & 1260 & 976 \\
\hline $\mathrm{SiO}_{2}$ & 61 & 414 & 451 & 458 & 408 & 488 & 406 \\
\hline $\begin{array}{l}\text { pH at room } \\
\text { temperature }\end{array}$ & 8.5 & 8.4 & 9.0 & 9.3 & 8.4 & 8.9 & 9.3 \\
\hline
\end{tabular}


deep and the occurrence and depth did not correlate wlth heat treatment or test time. A summary of the results is given in Tables 3.11-3.15

(Abraham-1986).

\subsection{Cu-Base Alloys}

\subsubsection{General Corrosion}

In electrochemical studles performed by McCright-1985, the temperature dependence of I cor and Ipas was evaluated for CDA 102, CDA 613 and CDA 715 In $\mathrm{J}-13$ well water and in an electrolyte which represents a $100 \mathrm{x}$ concentration of $\mathrm{J}-13$ well water. Figure 3.10 (McCrlght-1985) shows that there was no discernible temperature dependence of ' cor over 23 to $80^{\circ} \mathrm{C} \mathrm{In} \mathrm{J}-13$ well water. On the other hand, corrosion rates were generally hlgher and tended to increase with increasing temperature in the $100 x$ concentrated well water. The maximum corrosion rate in the study (about $10 \mathrm{ml} / \mathrm{s}$ per year) was observed for CDA 102 copper in 100X concentrated electrolyte at $80^{\circ} \mathrm{C}$.

Values of lpas for the three copper base alloys as a function of temperature and electrolyte concentration are shown in Figure 3.9 (McCright1985). These data show that there was a general trend of Increasing Ipas values with Increasing temperature for all three alloys in both electrolytes. As was observed for l cor values, Ipas values also tended to be higher in the concentrated electrolyte.

\subsubsection{Locallzed Corrosion}

McCright-1985 reported on the Influence of temperature and electrolyte concentration on corrosion and pitting potentlals for three copper base alloys. These parameters were determined in potentlodynamic polarization experiments performed in naturally aerated $\mathrm{J}-13$ well water and in an electrolyte representing a $100 x$ concentration of that water, at a scan rate of $1 \mathrm{mV} / \mathrm{sec}$. Detalls of the experiments are given in section 3.2 . Results of electrochemical measurements are given in Figures 3.12-3.14 (McCright-1985). These data show that the separation of $E_{p / t}$ and $E_{c o r}$, was higher for the more concentrated electrolyte and increased slight ly with increasing temperature. This analysis indlcates that pltting is less likely at the higher temperatures and in the electrolyte concentrated by bolling. It should be cautloned, however, that locallzed corrosion was observed at noble potentlals for many of the alloy-environment condltions and that the pltting analysis used by the author is deficlent in that protection potentlals were not reported; see section 3.2.2.

\subsubsection{Stress Corrosion Cracking (SCC)}

Data on thermal effects on stress corrosion cracking of copper-base alloys in the Tuff repository were not found in the literature. Stress corrosion cracking of copper base alloys has been reported in the literature from amblent temperatures (In environments such as ammonla [Pugh-1969]) up to $300^{\circ} \mathrm{C}$, (in boller feed water [Sato-1974a]). Thus, cracking is possible over the entire temperature range of operation of the repository. While mechanisms and rates of cracking may differ greatly for different environments, cracking in a given system may increase with Increasing 
temperature. For example, Uhlig-1975 and Johnson-1966 show that stress corrosion cracking of $\mathrm{Cu}-\mathrm{Zn}$ alloys follows Arrhenius behavior In ammonlum sulfate solutions. See Flgure 4.7 (Uhlig-1975). 


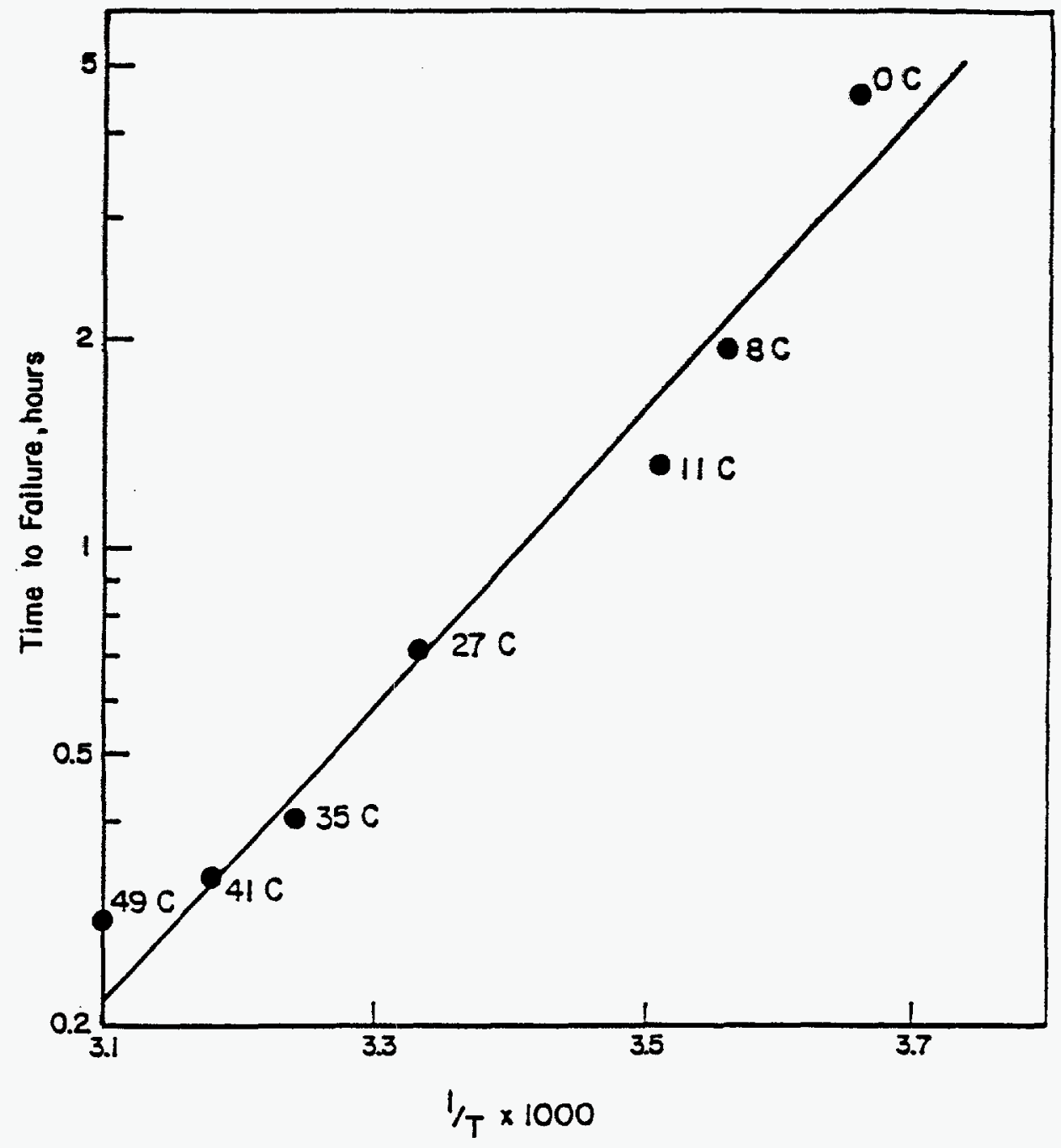

Figure 4.7 Effect of Temperature on Time To Fallure in $0.05 \mathrm{M} \mathrm{CuSO}_{4}$, $1 \mathrm{M}\left(\mathrm{NH}_{4}\right)_{2} \mathrm{SO}_{4}=\mathrm{DH}$ 6.5. (UhIlg-1975)

Reprinted by permission of the publisher. The Electrochemlcal soclety, Inc. 


\section{RADIATION EFFECTS ON CORROSION}

\section{$5.1 \mathrm{Fe}-\mathrm{Cr}-\mathrm{NI}$ Alloys}

\subsubsection{General Corrosion}

McCrlght-1984 exposed 1025 carbon steel, 9Cr-1Mo steel and Type 304L stalniess steel to air sparged $\mathrm{J}-13$ well water in the presence of a radlation fleld. The Type $304 \mathrm{~L}$ stalnless steel was evaluated in the solution annealed conditloned and in a solution annealed and sensitized condition. The specimens were solution annealed at $1050^{\circ} \mathrm{C}$ for 15 minutes and water quenched. The sensitized specimens were subsequently heated at $600^{\circ} \mathrm{C}$ for 10 hours and then alr cooled. Two temperature-radiation levels were evaluated: $105^{\circ} \mathrm{C}-3 \times 10^{5} \mathrm{Rads} / \mathrm{hour}$ and $150^{\circ} \mathrm{C}-6 \times 10^{5}$ Rads/hour. The tests were performed in autoclaves in a Cobalt-60 source. Alr-sparged $\mathrm{J}-13$ well water was flowed through the autoclaves at a rate of $35 \mathrm{ml} /$ hour. Crushed Topopah Spring Tuff was placed in the bottom of each autoclave so that some speclmens could be embedded in the rock.

A summary of the results of the 2-month experiment is given in Table 5.1 (McCright-1984). Comparison of these data with those in the absence of Irradiation, as shown in Table 5.2 (McCright-1984), Indlcates that solution annealed Type 304L stainless steel experlenced a moderate increase in corrosion rate as a result of radiation, whereas; 1025 carbon steel was unaffected by radlation. Corrosion rates for $9 \mathrm{Cr}-1$ Mo Increased by a factor of more than three as a result of radlation. Both with and without radiation, corrosion rates for Type 304L stainless steel were moderate; $0.5 \mathrm{um} / \mathrm{y}$, whlch corresponds to $0.5 \mathrm{~mm}$ thlckness loss in 1,000 years.

The data in Table 5.1 also show that the corrosion rates of sensitized Type 304L stainless steel specimens Increased with Increasing temperature whereas such an effect was not observed with the solution annealed materlal. Evidence of Intergranular attack of the sensitized specimens was not found. Comparative data at the elevated temperature $\left(150^{\circ} \mathrm{C}\right)$ in the absence of radlation were not reported (McCright-1984).

Juhas-1984 exposed solutions annealed and sensitized Type 304L stainless steel specimens to partlally aerated $\left(5 \mathrm{ppm} \mathrm{O}_{2}\right) \mathrm{J}-13$ water for 8,760 hours (1 year) at $28^{\circ} \mathrm{C}$. Specimens were exposed with 1 × $10^{5}$ Rads/hour radiation fleld and in the absence of a radiation fleld as a control. A summary of the results, given In Table 5.3 (Juhas-1984) shows that rates actually decreased with the addition of radiation, although the extent of corrosion was small in both cases. The sensltization heat treatment $\left(650^{\circ} \mathrm{C}\right.$ for 1 hour) had no effect on the results but the extent of sensitization of the specimens, based on a metallographlc examination, was small.

\subsubsection{Locallzed Corrosion}

Glass-1986a evaluated the influence of a radlation fleld on the freecorrosion potentlal of Type $316 \mathrm{~L}$ stalniess steel in $\mathrm{J}-13$ well water and a $10 x$ concentration of that water. A Cobalt 60 source was used with a dose rate of $3.3 \times 10^{6}$ Rads/hour. All experiments were performed at $30^{\circ} \mathrm{C}$ in alr saturated well water. Results of a typlcal experiment, given in Figure 5.1 (Glass-1986a), show that the radiation fleld caused a positive shift in the free-corrosion potentlal of about $200 \mathrm{mV}$. Figure 5.1 also 
Table 5.1 Corrosion Test Results For Carbon, Alloy And stainless steel Coupons In Radlated Environments (2-Wonth Exposure Data). (McCr Ight-1984)

Material

$\longrightarrow$

C1025

$9 \mathrm{Cr} \cdot 1 \mathrm{Mo}$

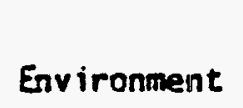

Environent

Corrosion Penetration Rate ( $\mu \mathrm{m} / \mathrm{yr}$ )

\begin{tabular}{cc}
$105^{\circ} \mathrm{c}(\mathrm{a})$ & $150^{\circ} \mathrm{C}^{(\mathrm{b})}$ \\
$3 \times 10^{5} \mathrm{rads} / \mathrm{hr}$ & $6 \times 10^{5} \mathrm{rads} / \mathrm{hr}$ \\
\hline
\end{tabular}

$$
\begin{array}{lll}
\text { J-13 water } & 34 ; 37 ; 36 ; 36 ; 36 & 107 ; 23 ; 20 ; 126 ; 18 ; 16 ; 18 \\
& \text { Avg: } 36 & \text { Avg: } 47 \\
\mathrm{~J}-13+\text { tuff } & 36 ; 57 ; 53 ; 36 ; 51 & 45 ; 41 ; 35 ; 34 ; 35 \\
& \text { Avg: } 47 & \text { Avg: } 38
\end{array}
$$

$$
\begin{array}{lll}
\text { J-13 water } & 14 ; 16 ; 14 ; 13 ; 15 ; 17 & 13 ; 14 ; 11 ; 13 ; 9.7 ; 11 ; 16 \\
& \text { Avg: } 15 & \text { Avg: } 13
\end{array}
$$$$
\text { Avg: } 13
$$

$$
3-13+\text { tuff }
$$$$
20 ; 20 ; 21 ; 22 ; 21 ; 23
$$

Avg: 21

$41 ; 30 ; 32 ; 26 ; 23 ; 50 ; 38$

Avg: 34

$304 \mathrm{~L}$

J-13 water

$0.31 ; 0.31$

0.36

(Solution annealed) $\mathrm{J}-13+$ tuff

$0.29 ; 0.32$

0.31

$304 \mathrm{~L}$ (solution

J-i3 water

$0.23: 0.37$

0.51

annealed + "sensi- $J-\{3+$ tuff

$0.25 ; 0.30$

0.55

(a) Tests conducted in Inconel 600 vessel.

(b) Tests conducted in Titanium - Grade 2 vessel. 
Table 5.2 Corrosion Test Results For Different steel Coupons Exposed To $100^{\circ} \mathrm{C}$ Tuff-Conditloned Water And steam 1000-hour Exposure of TrIpIlcato Coupons. (McCrlght-1984)

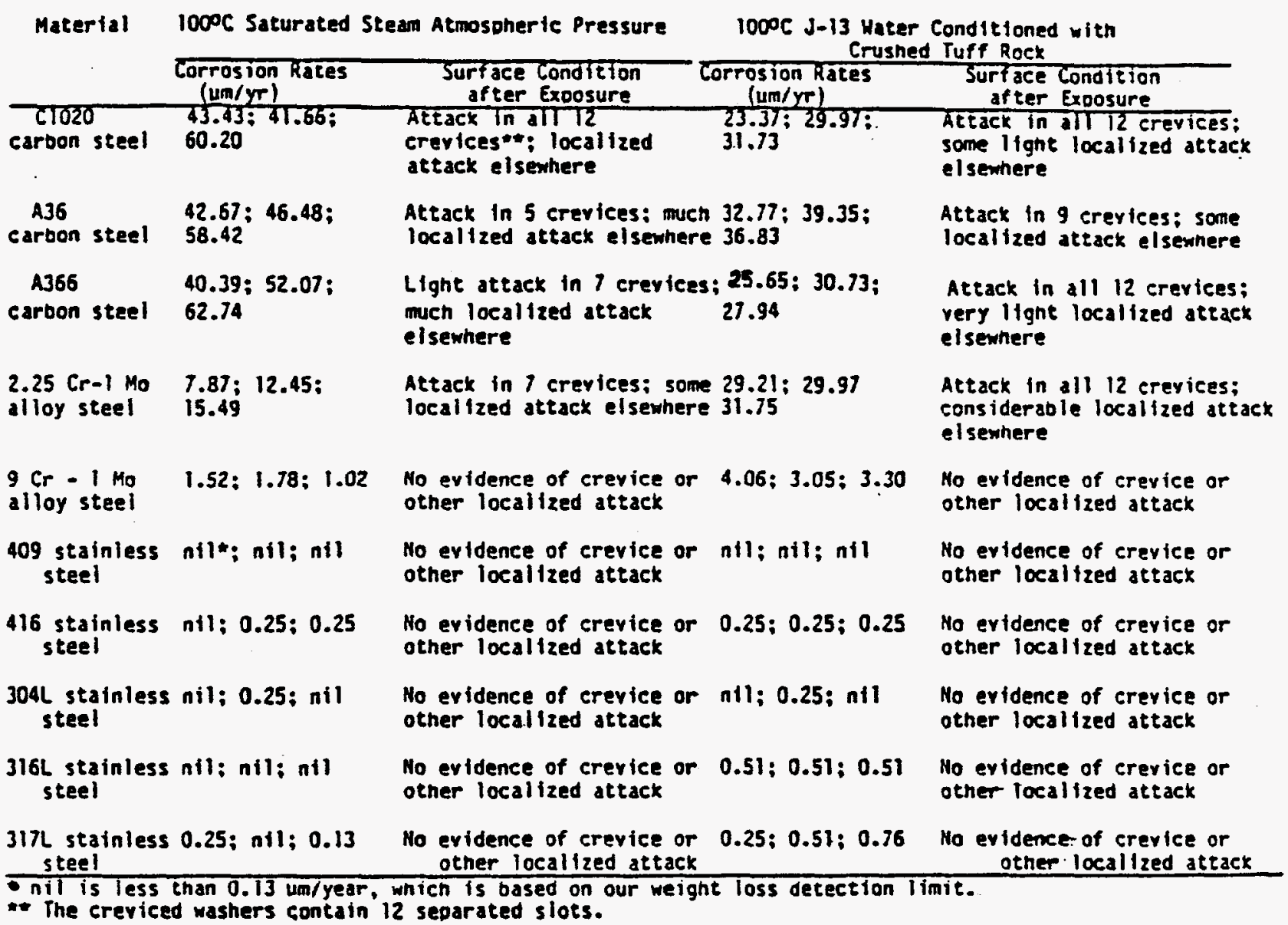


Table 5.3 Corrosion Test Results For Room Temperature Irradlated And Non-Irradlated 304L Coupons ( 8760 Hrs Exposure). (Juhas-1984)

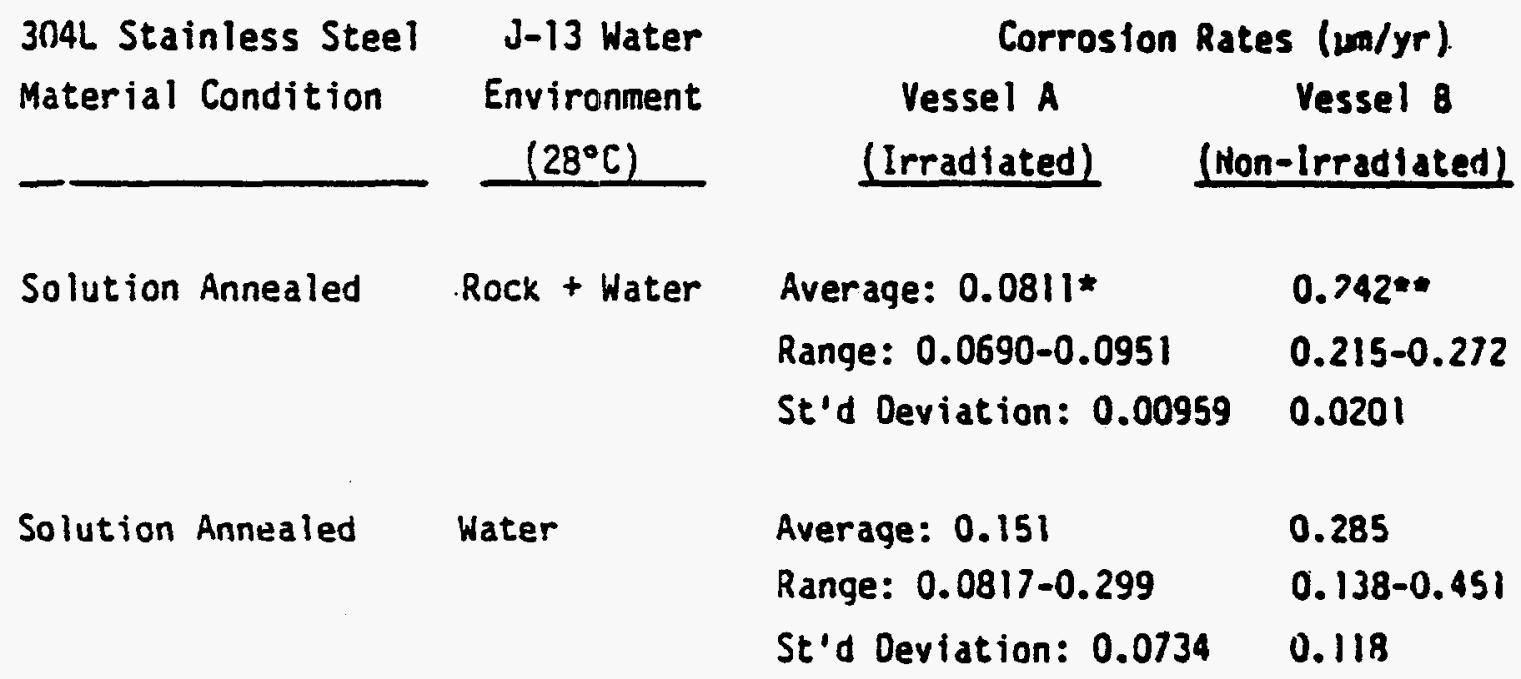

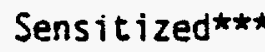

Rock + Water Average: 0.123

0.249

fiange: $0.111-0.142$

$0.165-0.322$

St'd Deviation: 0.0114

0.0522

Sensitized

Water

Average: 0.116

0.283

Range: $0.092-0.142$

$0.203-0.452$

St'd Deviation: 0.0470

0.0980

- Averages of 6 coupons in each set.

* Maximum localized penetration measured $=0.010$ um in 8760 nnurs (appx. 1 year).

$\star * *$ "Sensitizing" heat treatment: 1 hour at $650^{\circ} \mathrm{C}$. 


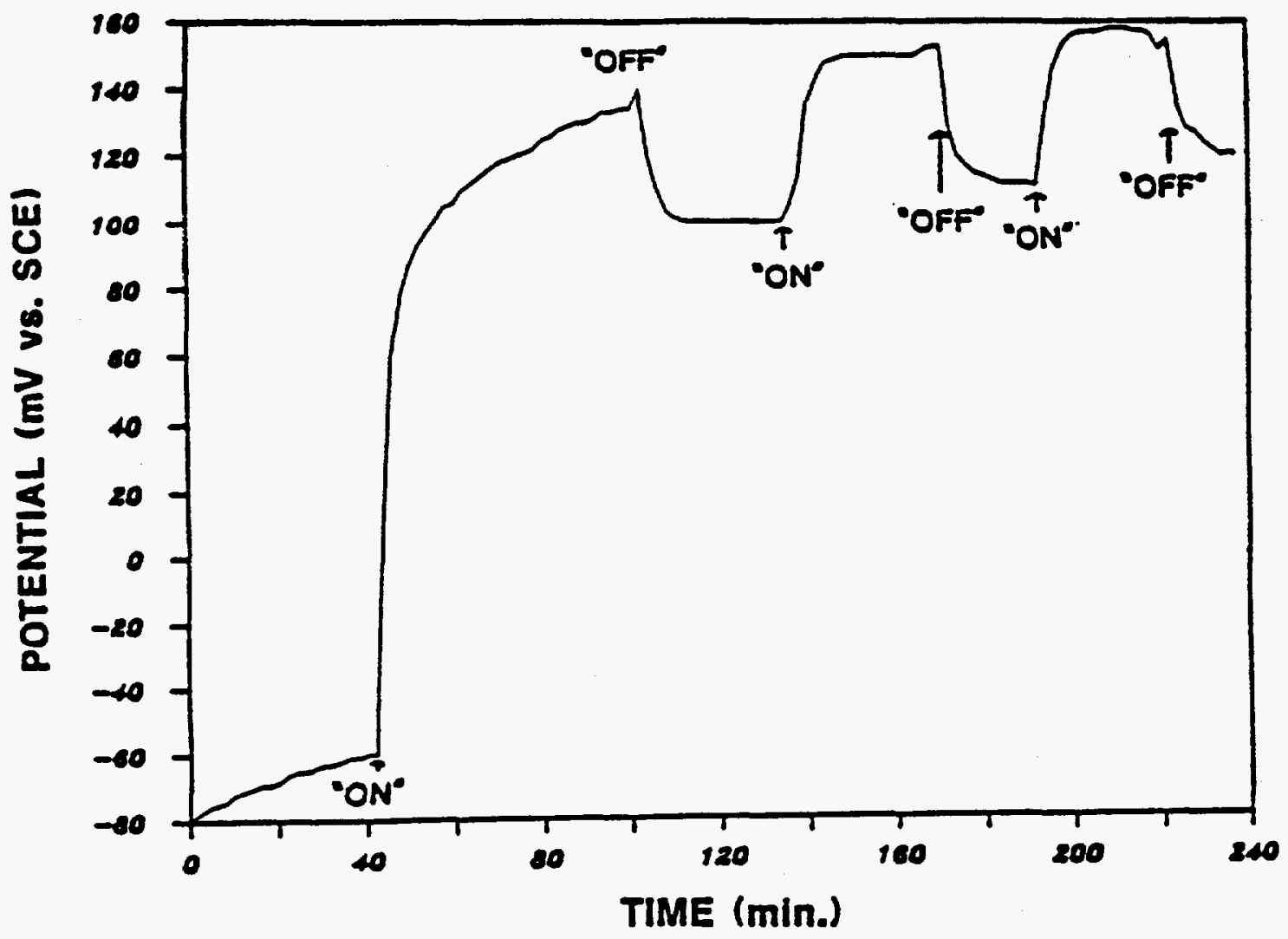

FIgure 5.1 Corrosion Potentlal Behavlor for AlSI 316L Stainless Steel In 10X Concentrated J-13 Well Water Under Gamma Irradiation. The Solution Was Not Exposed To Irradiation Prior To Initlation of The First "On/Off" Irradlation Cycle. (Glass-1986a) 
shows that, when the fleld was removed, a subsequent negative shift of about $50 \mathrm{mV}$ was observed. This $50 \mathrm{mV}$ shlft was revers lble in subsequent cycles. This behavior indicates that permanent changes in the groundwater or passive film on the metal occurred as a result of the radiation. In a subsequent experiment, fresh $\mathrm{J}-13$ well water was added to the cell after one on-off cycle. The results, given in Figure 5.2 (Glass-1986a) show that there was more potentlal recovery than in the previous experiment but aga In not all of the positive potentlal shlft was recovered when the radiation fleld was removed and the solution was changed. Thus, some modification in the passive film on the specimen also must have occurred as a result of the exposure to radiation.

Glass-1986a a lso evaluated the Influence of $\mathrm{H}_{2} \mathrm{O}_{2}$ on the free-corrosion potential of Type 316L stainless steel in $\mathrm{J}-13$ well water. Results, shown In FIgure 5.2 and 5.3 (Glass-1986a) demonstrate that potentlal shifts simllar to those observed in a radiation fleld occurred as a result of $\mathrm{H}_{2} \mathrm{O}_{2}$ additions. Based on these observations, it was concluded that $\mathrm{H}_{2} \mathrm{O}_{2}$ and $\mathrm{OH}$ radical production are responslble for the potentlal shifts observed for Type 316L stalniess steel in the presence of a radiation fleld. These potentlal shlfts are of importance to pitting corrosion since they may move the corrosion potential into a potentlal range where pltting will occur, as discussed below.

In other work, Glass-1986b performed potent lodynamic polarlzation tests on Type 316L stainless steol in a dllute $\mathrm{NaCl}$ solution (650ppm $\mathrm{Cl}$ ) with and without gamma Irradiation. The experiments were performed at $30^{\circ} \mathrm{C}$ and 3.3 $x 10^{6} \mathrm{Rads} /$ hour in air saturated solutions. Results, given In Figure 5.4 (Glass-1986b) show that the pltting potential was not greatly affected by the radlation whereas the corrosion potentlal, Ecor moved about $200 \mathrm{mV}$ in the positive direction when Irradiated. Thus, the value of $E_{p / t}-E_{c o r}$ was less in the presence of Irradlation Indlcating a greater likel Ihood of pltting. However, It was concluded by the authors that the shift of the corrosion potentlal was not sufficlent to move Type $316 \mathrm{~L}$ stainless steel Into the pltting regime.

It is the opInion of Cortest columbus that this conclusion is not valid in the absence of protectlon potentlal data. Basing predictions on $E_{p l t}$ is simply not conservative for long term performance where crevices wili be present. In fact, Glass-1985 recorded potentiodynamic polarlzation curves for Type 316L stainless steel in dilute $(650 \mathrm{ppm})$ chlorlde under Identlcal test conditions in which reverse scans were performed. The results, shown in Figure 5.5 (Glass-1985) indicate somewhat different values of $E_{p i t}$ from those previously reported for both test conditions. On the other hand, Ecor values were similar to those previously reported for both test conditions. In splte of these differences, the conclusions drawn from Figure 5.5 would be similar to those drawn from Figure 5.4 , based on the authors analysis technique.

However, further analysis of the curves in Figure 5.5 indicates simllar Eprot values for Irradlated and nonIrradiated condltions of $+0.02 V$ (SCE). Thus, Ecor is more positive than Eprot for Irradiated condltions, predicting a finlte probabllity of pitting in a radiation fleld.

PItman-1986 exposed specimens of Type 304L stalnless steel, Type 304 stainless steol and Type $316 \mathrm{~L}$ stainless steel at 50 and $90^{\circ} \mathrm{C}$ and maximum radiation levels of $5 \times 10^{5}$ and $3 \times 10^{5}$ Rads/hour, respectively, for 


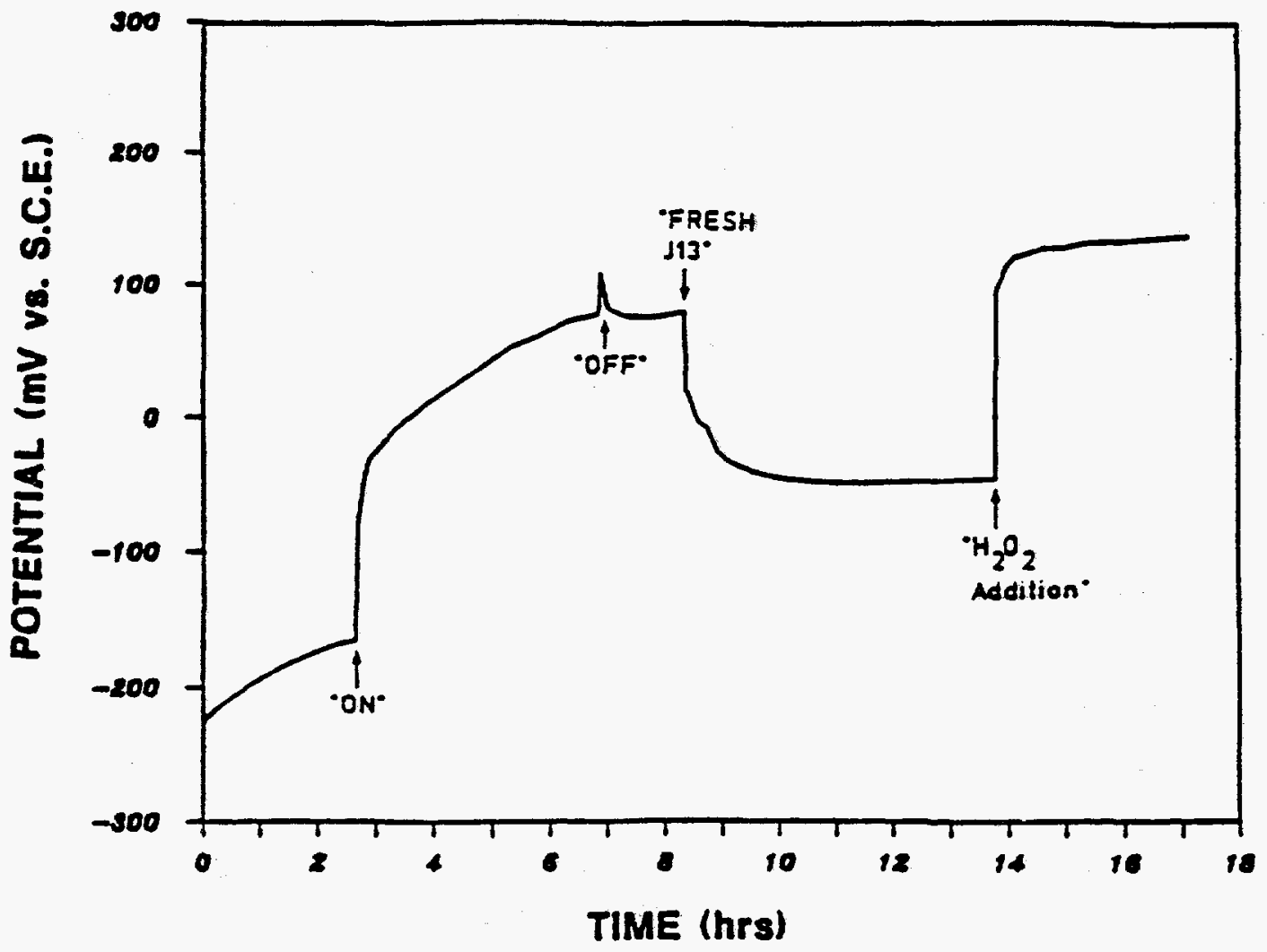

FIgure 5.2 Corrosion Potent Ial Behavior For AlSI 316L Stainless Steel In Gamna-Irradiated J-13 Well Water. Following The "Off" HalfCycle The Irradlated Solution Was Decanted And Replaced By A Fresh, Unirradiated Solut lon. Following This, $\mathrm{H}_{2} \mathrm{O}_{2}$ Was Added To solut Ion At A Concentration of $0.4 \mathrm{mM}$. (Glass-1986a) 


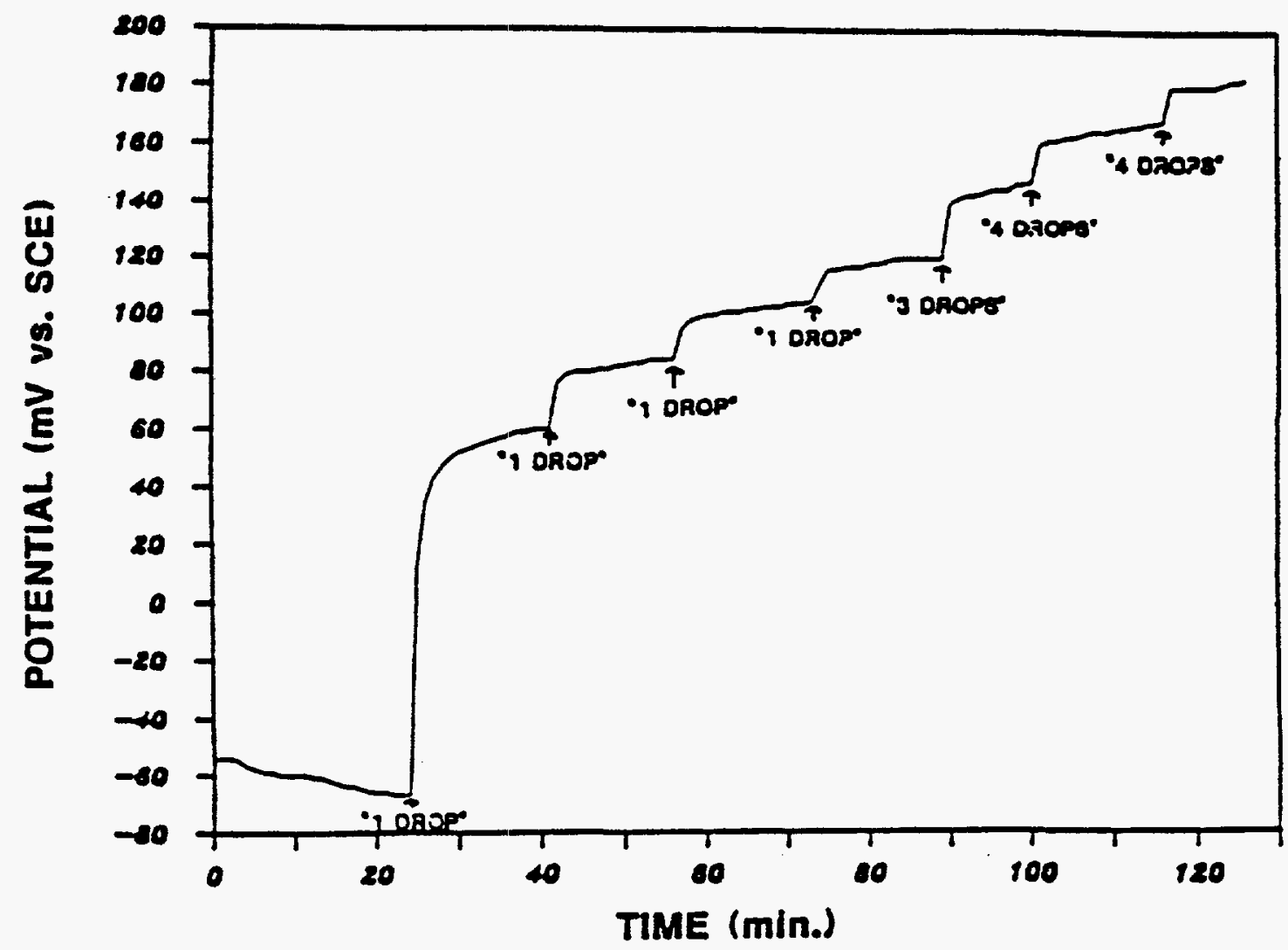

Flgure 5.3 Response of The Corrosion Potentlal For Alsi 316L Stalnless Steel In UnIrradiated J-13 Well Water To $\mathrm{Wh} / \mathrm{ch}$ Successive Additions of $\mathrm{H}_{2} \mathrm{O}_{2}$ Were Made. In This Figure, One Drop of $\mathrm{H}_{2} \mathrm{O}_{2}$ (From A $30 \%$ Solution) Represents A Resulting Solution Concentration of $0.5 \mathrm{mM}$. The Solution Was Cont I nuousiy st Irred By A Magnetic Stirrer Throughout The Exper Iment. (Glass, 1986a) 


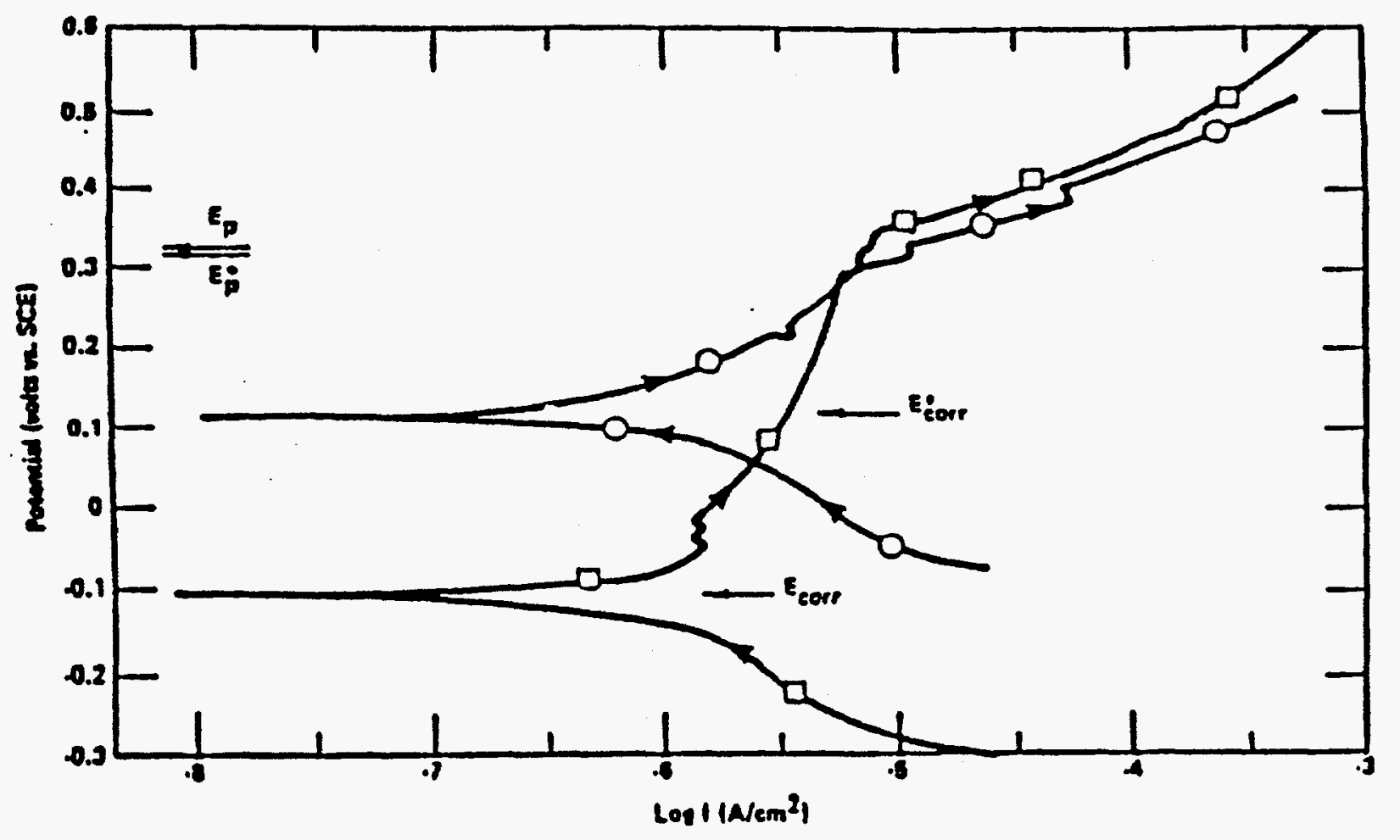

Flgure 5.4 Comparison of The Potentlodynamlc Anodle Polarization Behavlor For 316L Stalnless steel In $0.018 \mathrm{M} \mathrm{NaCl}$ solution In Delonlzed Water With And Without Gamma Irradlation ( 0 . UnIrradlated; o. Irradlated). (Glass, 1986b)

Reprinted with permission of Pergamon Press, publlsher of the Corrosion Sclence. Vol. 26, No. 8, 1986. 


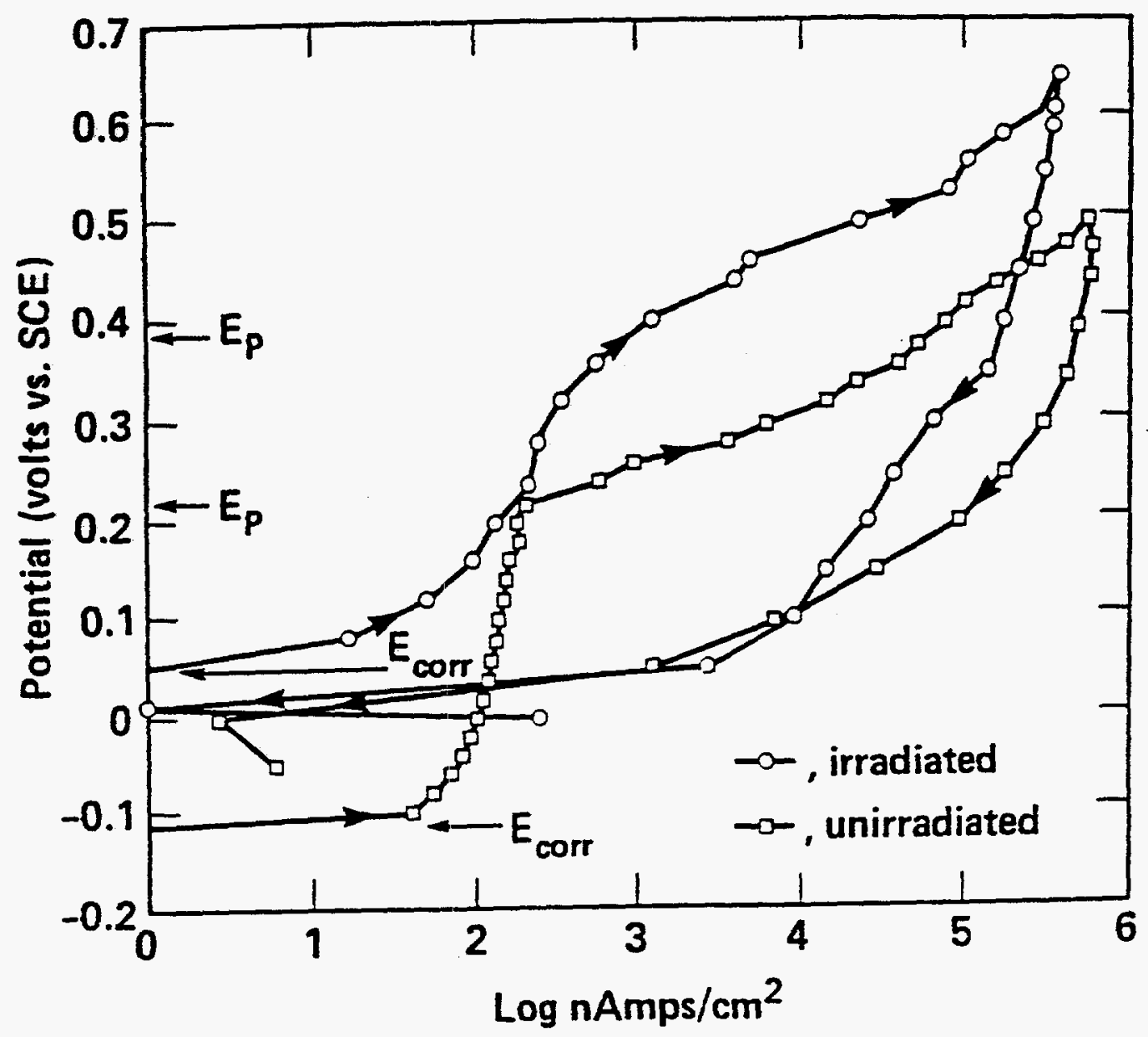

Flgure 5.5 Comparison of The Potentlostatle Anodle Polarlzat Ion Behavior For $316 \mathrm{~L}$ Stalniess Steol in $650 \mathrm{ppm} \mathrm{Cl}$ - Solution in Delonized Water WIth And Without Gamma Irradiation. (Glass-1985) 
perlods up to 2 years in Inconel 600 autoclaves. Two materlal conditlons were evaluated; solution annealed $\left(15 \mathrm{minutes}\right.$ at $\left.1050^{\circ} \mathrm{C}\right)$ and solutlon annealed $\left(15 \mathrm{~m} /\right.$ nutes at $\left.1050^{\circ} \mathrm{C}\right)$ and sensit/zed $\left(24\right.$ hours at $\left.600^{\circ} \mathrm{C}\right)$. The specimens were exposed in three zones in the autoclaves: (1) alrvapor, (2) crushed tuff and alr vapor, and (3) water and crushed tuff. After about 2 years exposure, the specimens were examined. In general, specimens exposed to the rock/vapor and vapor-only reglons showed the most surface corrosion, consisting primarlly of patches of red-brown oxide. No signs of signiflcant pltting attack were observed on any of the specimens. The apparent discrepancy between these results and the electrochemical analysis descrlbed above may have bsen a result of the lower radiation fleld used in the long-term tests.

\subsubsection{Stress Corrosion Cracking (SCC)}

Juhas-1984 and PItman-1986 reported on the results of constant deflection (U-bend) and slow-straln-rate (SSR) stress corrosion tests performed on candidate stainless steels in simulated Tuff repository environments in the presence of a radiation fleld. The U-bend tests were performed on specimens machined from sheet stock of Type 304 and Type $304 \mathrm{~L}$ stainless steel. Their chemical compositlons are given In Table 5.4 (PItman-1986). Two heat treatments were evaluated:

- Solution Annealed (SA) - 15 minutes at $1050^{\circ} \mathrm{C}$, a $/ \mathrm{r}$ cooled, and

- SA + Sensitized - 15 minutes at $1050^{\circ} \mathrm{C}$, alr cooled, followed by a 24 hours at $600^{\circ} \mathrm{C}$, water quenched.

The U-bend tests were performed In autoclaves at $50^{\circ} \mathrm{C}$ and $90^{\circ} \mathrm{C}$ and maximum irradiation intensities of $5 \times 10^{5}$ and $3 \times 10^{5}$ Rads/hour respectively. The specimens were immersed in three zones in each autoclave;

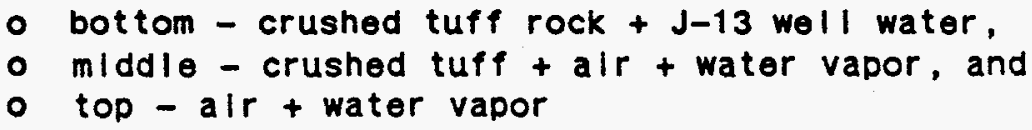

During the exposure, each autoclave was sparged dally with $240 \mathrm{ml}$ of alr and the tests were performed at amblent pressure.

The specimens were examined for cracking following 1, 3, 5, 7, and 24 or 25 months of exposure; those specimens showing obvious cracks were removed from exposure. A summary of the results of the test is given in Table 5.5 ( $P \mid t m a n-1986$ ). These data show that a total of 15 fallures were observed in the 48 specimens evaluated. The fallure time for each specimen is Indlcated in the Table. Elght of the 15 fallures occurred in the vapor only (top) reglon of the autoclaves; 10 of the 15 fallures occurred at the high temperature, $90^{\circ} \mathrm{C}$, which also corresponded to the lower radiation fleld.

of the 15 fallures, 11 occurred in the Type 304 stainless steel and 10 of those 11 occurred in the sensitized microstructure. The SCC in the sensitlzed microstructure was intergranular and was antlclpated as sensitized Type 304 stainless steel is known to be highly susceptible to SCC in rela$t$ ively benign aqueous environments. 
Tablo 5.4 Chemical Compositions And Mechanlcal Propertles of Stainless Steol Test Materlals. (PItman-1986)

\section{Chemical Comoositions}

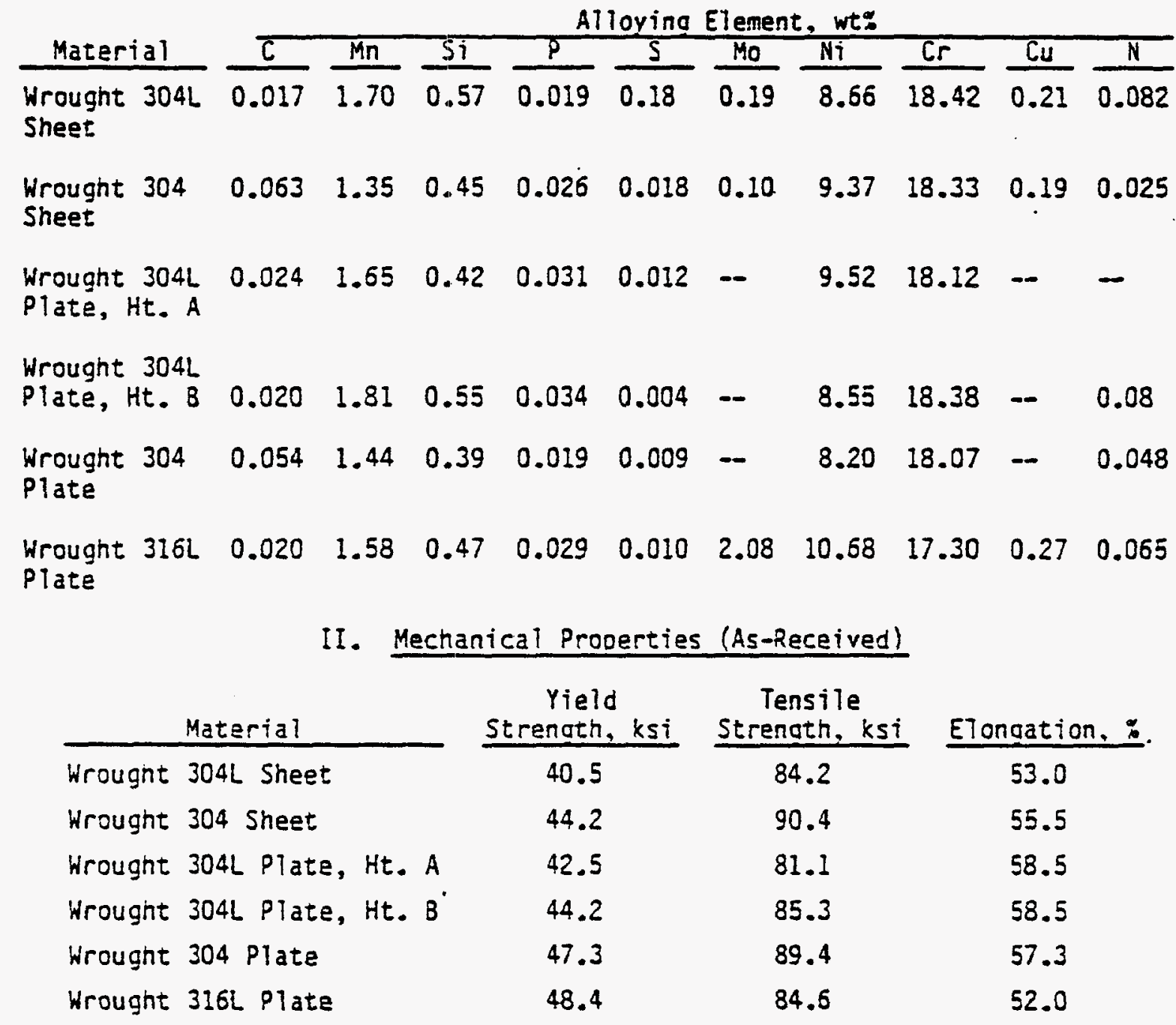


Table 5.5 Summary of Irradlation-Corrosion Test Data. (PItman-1986)

\begin{tabular}{|c|c|c|c|c|c|}
\hline \multirow[b]{2}{*}{ Environment } & \multirow[b]{2}{*}{ Material } & \multicolumn{2}{|c|}{$\begin{array}{c}50^{\circ} \mathrm{C} \text { Test, } \\
5 \times 10^{5} \mathrm{rad} / \mathrm{h}(\max .) \\
\end{array}$} & \multicolumn{2}{|c|}{$\begin{array}{l}90^{\circ} \mathrm{C} \text { Test, } \\
3 \times 10^{5} \mathrm{rad} / \mathrm{h}(\max .) \\
\end{array}$} \\
\hline & & Soecimen & $\begin{array}{l}\text { Failure } \\
\text { Time, mo } \\
\end{array}$ & Soecimen & $\begin{array}{l}\text { Failure } \\
\text { Time, mo } \\
\end{array}$ \\
\hline Vapor only & $\begin{array}{l}304 L . S A(a) \\
304 L \text { SAS }(b) \\
304 \text { SA } \\
304 \text { SAS } \\
304 L \text { SA } \\
304 L \text { SAS } \\
304 \text { SA } \\
304 \text { SAS }\end{array}$ & $\begin{array}{l}p 419 \\
P 431 \\
P 443 \\
P 455 \\
p 421 \\
p 433 \\
P 445 \\
P 457\end{array}$ & 3 & $\begin{array}{l}P 420 \\
P 432 \\
P 444 \\
P 456 \\
P 422 \\
P 434 \\
P 446 \\
P 458\end{array}$ & $\begin{array}{r}10 \\
5 \\
23 \\
14 \\
23 \\
3\end{array}$ \\
\hline Rock/vapor & $\begin{array}{l}304 L \text { SA } \\
304 L \text { SAS } \\
304 \text { SA } \\
304 \text { SAS } \\
304 L \text { SA } \\
304 L \text { SAS } \\
304 \text { SA } \\
304 \text { SAS }\end{array}$ & $\begin{array}{l}P 423 \\
P 435 \\
P 447 \\
P 459 \\
P 425 \\
P 437 \\
P 449 \\
P 461\end{array}$ & 25 & $\begin{array}{l}P 424 \\
P 436 \\
P 448 \\
P 460 \\
P 426 \\
P 438 \\
P 450 \\
P 462\end{array}$ & 14 \\
\hline Rock/groundwater & $\begin{array}{l}304 L \text { SA } \\
304 L \text { SAS } \\
304 \text { SA } \\
304 \text { SAS } \\
304 L \text { SA } \\
304 L \text { SAS } \\
304 \text { SA } \\
304 \text { SAS }\end{array}$ & $\begin{array}{l}P 427 \\
P 439 \\
P 451 \\
P 463 \\
P 429 \\
P 441 \\
P 453 \\
P 465\end{array}$ & 24 & $\begin{array}{l}P 428 \\
P 440 \\
P 452 \\
P 464 \\
P 430 \\
P 442 \\
P 454 \\
P 466\end{array}$ & 1 \\
\hline
\end{tabular}

(a) Solution annealed (1050 $\mathrm{C}$ for $15 \mathrm{~min}$, air cooled)

(b) Solution annealed and sensitized $\left(600^{\circ} \mathrm{C}\right.$ for $\left.24 \mathrm{~h}\right)$ 
The most surprising result of the study was the occurrence of SCC in the solutions annealed Type 304L stainless steel specimen (WP422). This fallure occurred in the reference contalner materlal under opt Imum metallurglcal conditions ( $l . \theta$. no sensltization, extensive cold work, welding, etc.) under vapor phase condltions whlch are thought to represent fleld condltions over the first few hundred years of repository life. A metallographlc examination of that specimen Indlcated that the SCC was transgranular whlch is characteristlc of SCC in non-sensitized stalnless steels. The SCC observed in the sensitized Type 304L stainless steel specimens also was transgranular, suggesting that the sensitization heat treatment did not play a role in the cracking observed. Similarly, the SCC observed in the solution annealed Type 304 stainless steel specimens also was transgranular.

Efforts were made to Identify the specles responsible for the transgranular SCC observed. Following exposure, the speclmen surfaces were analyzed by $x-r$ ay photoelection spectroscopy, (XPS). The analys/s showed no evldence of $\mathrm{hlgh}$ concentrations of $\mathrm{Cl}$ or other specles known to promote SCC of stalnless steels.

\subsection{Cu-Base Alloys}

\subsubsection{General Corrosion}

Yunker-1986a evaluated the corrosion behavlors of CDA 101, CDA 613 and CDA 715 copper alloys in J-13 water under an Irradlation fleld of $1 \times 10^{5}$ R/hour. Welght-loss specimens of the 3 alloys were exposed to 3 environments :

(1) J-13 well water at $95^{\circ} \mathrm{C}$,

(2) a Ir saturated with water vapor at $95^{\circ} \mathrm{C}$, and

(3) $150^{\circ} \mathrm{C}$ - air, water vapor.

For condition (2), the gas phase temperature was malntalned at $2^{\circ} \mathrm{C}$ above the water temperatur.e, $\mathrm{m}|\mathrm{n}| \mathrm{m}|\mathrm{z}| \mathrm{n} g$ condensation of 1 lquld on the specimens. The compositions of the alloys used in the study are given in Table 5.6 (Yunker-1986a). Note that, In these studies, CDA 101 was used in place of CDA 102 and CDA 614 was used in place of CDA 613; CDA 101 is of higher purity than CDA 102 while the specifled compositional ranges for CDA 613 and CDA 614 overlap extensively. The authors considered the materlals to be interchangeable. Following exposure, the specimens were cleaned of oxIde $f 1 / m$, according to ASTM procedure GI and welght-loss was determined.

A summary of the results of the gravimetrlc measurements, as reported by Acton-1986 is given in Table 5.7 (Acton-1986). The data in Table 5.7 show that general corrosion rates decreased with time for all 3 test conditlons and 3 alloys. In general, rates were highest in saturated steam at $95^{\circ} \mathrm{C}$, and lowest in unsaturated steams at $150^{\circ} \mathrm{C}$. The most severe corrosion appeared to be related to the presence, In the vapor phase, of small droplets of llquld on the metal surface. Surprisingly, CDA 715 exhiblted the highest corrosion rate, based on weight-loss, of the 3 alloys evaluated.

A comparison of welght-loss test results under Irradlated and nonIrradlated conditlons, shown in Table 5.8 (Acton-1986), Indlcates that CDA 715 experlenced the greatest increase in corrosion rate with Irradia- 
Table 5.6 Composition of Corrosion Specimens. (Yunker-1986a)

Element

Aluminum

Cadmium

Carbon

Cobalt

Copper

Iron

Lead

Manganese

Mercury

Nickel

Phosphorus

Sulfur

Tin

Zinc

CDA $101^{\star}$

$0.001 \max$

Alloy Composition (wt\%)

6.75

CDA 715

0.01

0.04

90.82

69.18

2.46

0.53

$0.001 \max$

0.01

0.16

0.01

0.51

$0.0001 \max$

0.05

29.6

$0.0003 \max$

0.002

$0.0018 \max$

0.01

$0.0001 \max$

0.02

0.01

0.07

*Copper Development Association (CDA) identification number. 
Table 5.7 Uniform Corrosion Rate Determinat lons For Copper And CopperBase Alloys Under Strongly Irradiated Conditions (ca. $10^{5}$ rads/hr). (Acton-1986)

\begin{tabular}{|c|c|c|}
\hline $\begin{array}{l}\text { Exposure } \\
\text { Conditions } \\
\end{array}$ & $\begin{array}{l}\text { Exposure } \\
\text { Time (months) }\end{array}$ & $\begin{array}{l}\text { Corrosion } \\
\text { Rate (mils/yr)* }\end{array}$ \\
\hline \multicolumn{3}{|c|}{$\operatorname{COA~101^{**}}$} \\
\hline \multirow{3}{*}{$\begin{array}{l}150^{\circ} \mathrm{C} \\
\text { Unsaturated Stean }\end{array}$} & 1 & 0.069 \\
\hline & 3 & 0.033 \\
\hline & 6 & 0.031 \\
\hline \multirow{3}{*}{$\begin{array}{l}95^{\circ} \mathrm{C} \\
\text { Saturated } \\
\text { Steam }\end{array}$} & 1 & 0.26 \\
\hline & 3 & 0.21 \\
\hline & 7 & 0.161 \\
\hline \multirow{3}{*}{$\begin{array}{l}95^{\circ} \mathrm{C} \\
\mathrm{J}-13 \text { Water }\end{array}$} & 1 & 0.135 \\
\hline & 3 & 0.084 \\
\hline & 7 & 0.080 \\
\hline \multicolumn{3}{|c|}{$\operatorname{CDA} 614^{* *}$} \\
\hline \multirow{3}{*}{$\begin{array}{l}150^{\circ} \mathrm{C} \\
\text { Unsaturated } \\
\text { Steam }\end{array}$} & 1 & 0.033 \\
\hline & 3 & 0.020 \\
\hline & 6 & 0.013 \\
\hline \multirow{3}{*}{$\begin{array}{l}95^{\circ} \mathrm{C} \\
\text { Saturated } \\
\text { Steam }\end{array}$} & 1 & 0.217 \\
\hline & 3 & 0.080 \\
\hline & 7 & 0.071 \\
\hline \multirow{3}{*}{$\begin{array}{l}95^{\circ} \mathrm{C} \\
\mathrm{J}-13 \text { Water }\end{array}$} & 1 & 0.071 \\
\hline & 3 & 0.073 \\
\hline & 7 & 0.044 \\
\hline
\end{tabular}


Table 5.7 (Continued).

\begin{tabular}{|c|c|c|}
\hline $\begin{array}{l}\text { Exposure } \\
\text { Conditions }\end{array}$ & $\begin{array}{l}\text { Exposure } \\
\text { Time (months) }\end{array}$ & $\begin{array}{l}\text { Corrosion } \\
\text { Rate (mils/yr)* }\end{array}$ \\
\hline \multicolumn{3}{|c|}{ CDA 715} \\
\hline \multirow{3}{*}{$\begin{array}{l}150^{\circ} \mathrm{C} \\
\text { Unsaturated } \\
\text { Steam }\end{array}$} & 1 & 0.18 \\
\hline & 3 & 0.076 \\
\hline & 6 & 0.036 \\
\hline \multirow{3}{*}{$\begin{array}{l}95^{\circ} \mathrm{C} \\
\text { Saturated } \\
\text { Steam }\end{array}$} & 1 & 0.47 \\
\hline & 3 & 0.54 \\
\hline & 7 & 0.22 \\
\hline \multirow{3}{*}{$\begin{array}{l}95^{\circ} \mathrm{C} \\
\mathrm{J}-13 \text { Water }\end{array}$} & 1 & 0.101 \\
\hline & 3 & 0.14 \\
\hline & 7 & 0.090 \\
\hline
\end{tabular}

* Corrosion rates calculated from weight loss experienced by 1 to 3 specimens for each test condition.

** In some of the work, specimens of CDA 101 were used in place of CDA 102 and specimens of CDA 614 mere used in place of CDA 613. CDA 101 is a higher purity copper than CDA 102, while the specified composition ranges of CDA 613 and CDA 614 overlap extensively and differ only in the maximum specification of minor elements. For the purposes of this study, the respective materials are considered interchangeable. 


\section{Table 5.8 Comparison of Corrosion Rates For Copper And Copper-Base Alloys In Irradlated And Non-Irradlated Environments, mils/yr. (Acton-1986)}

\begin{tabular}{|c|c|c|c|c|c|c|}
\hline Alloy & $\begin{array}{l}\text { Non-Irradiated } \\
\text { Unsaturated } \\
\text { Steam, } 150^{\circ} \mathrm{C} \\
(-4 \text { months })\end{array}$ & $\begin{array}{l}\text { Irradlated } \\
\text { Unsaturated } \\
\text { Steam, } 150^{\circ} \mathrm{C} \\
\text { ( }-6 \text { months) }\end{array}$ & $\begin{array}{l}\text { Non-Irradiated } \\
\text { Saturated } \\
\text { Steam, } 100^{\circ} \mathrm{C} \\
(-8 \text { months })\end{array}$ & $\begin{array}{l}\text { Irradlated } \\
\text { Saturated } \\
\text { Steam, 95 }{ }^{\circ} \mathrm{C} \\
(\sim 7 \text { months) }\end{array}$ & $\begin{array}{l}\text { Non-Irradlated } \\
J-13 \text { Water } \\
100^{\circ} \mathrm{C} \\
(\sim 8 \text { months })\end{array}$ & $\begin{array}{l}\text { Irradlated } \\
\mathrm{J}-13 \text { Water } \\
95^{\circ} \mathrm{C} \\
(\rightarrow 7 \text { months })\end{array}$ \\
\hline $\operatorname{COA} 101 / 102$ & 0.061 & 0.031 & 0.124 & 0.161 & 0.083 & 0.080 \\
\hline $\operatorname{coA} 613 / 614$ & 0.014 & 0.013 & 0.090 & 0.071 & 0.059 & 0.044 \\
\hline $\operatorname{coA} 715$ & 0.002 & 0.036 & 0.014 & 0.22 & 0.040 & 0.090 \\
\hline
\end{tabular}


tion, of the 3 alloys evaluated. In contrast, CDA 101/102 and CDA 613/614 experlenced elther decreases or moderate Increases in corrosion rates for the 3 environments with the addition of radiation.

Yunker-1986b reported on a cont Inuation of the above exper Iments for a total exposure of 14 months. Results, summarlzed In Table 5.9 (Yunker1986b) and Figures 5.6-5.8 show essentlally simllar trends to those reported by Acton-1986. As shown In the flgures, the data were fltted to curves of the form $w=K t^{n}+C$ where:

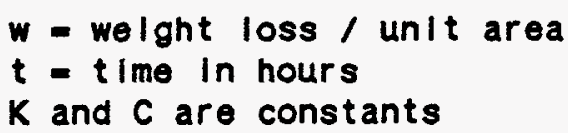

The exponents for the 3 alloys were:

$$
\begin{aligned}
& \text { CDA } 101-0.59 \\
& \text { CDA } 613=0.45 \\
& \text { CDA } 715-0.37
\end{aligned}
$$

The low values of the exponents (<1) indicate that corrosion rates decreased with time over the exposure perlod.

\subsubsection{Locallzed Corrosion}

In Yunker-1986a, evaluation of the corrosion behavior of copper base alloys in Irradiated $J-13$ well water, crevlced specimens were included in the testing. The creviced specimens were prepared by bolting Identical flat plate speclmens together to create a crevlce. The mating surfaces of the crevlce were pollshed with $600 \mathrm{grlt}$ abrasive prior to exposure. Following exposure, the free surfaces and the crevices were optlcally examined for evidence of pitting and crevice corrosion, respectively. As descrlbed in section 5.2.1, 3 alloys, CDA 101, CDA 613 and CDA 715 were evaluated in $\mathrm{J}-13$ well water at $95^{\circ} \mathrm{C}$, alr saturated with water vapor at $95^{\circ} \mathrm{C}$ and alr-water vapor at $150^{\circ} \mathrm{C}$. The radlation fleld was $1 \times 10^{5}$ R/hour.

Acton-1986 reported on the results of an analys/s of 45 of the 116 speclmens from 1, 3 and 6 to 7 month exposures. Several different types of locallzed corrosion were reported. Evldence of modest crevice corrosion In the metal to metal crevices and beneath alumina spacers was observed. The extent of crevlce corrosion was least on pure copper and most extensive on aluminum bronze and $\mathrm{Cu}-30 \mathrm{NI}$. Actual depths of attack were not reported.

PItting corrosion also was observed on the free surfaces of coupons of all 3 alloys. The pltting appeared to be most severe on CDA 715 , with broad plts around the alumina support washers. CDA 613 specimens exhlbited pltting along the fusion welds of the stress corrosion specimens. Fillform corrosion also was reported on some of the CDA 613 specimens. This form of corrosion is generally assoclated with organlcally coated speclmens but the authors indlcated that the attack occurred beneath oxide flims on the specimens. Pltting was least severe on the pure copper specimens. The localized attack on the free surfaces of the specimens was most severe in the vapor and appeared to the authors to be related to the 
Table 5.9 Welght Loss And Unlform Corroslon Rates. (Yunker-1986b)

\begin{tabular}{|c|c|c|c|c|}
\hline \multirow{3}{*}{ COA 101} & \multicolumn{2}{|c|}{ Exposure } & \multicolumn{2}{|c|}{ Rance of } \\
\hline & $\begin{array}{l}\text { Temperature } \\
\text { ('c)/Phase }\end{array}$ & $\begin{array}{l}\text { Time } \\
\text { (hours) }\end{array}$ & $\begin{array}{l}\text { Metal Loss } \\
\text { (mo) }\end{array}$ & $\begin{array}{c}\text { Corrosion Rates } \\
\text { (mi)/year) } \\
\end{array}$ \\
\hline & $\begin{array}{l}\text { 95/Gas } \\
\text { 95/Liquid }\end{array}$ & $\begin{array}{r}836 \\
2334 \\
4392 \\
10,078 \\
720 \\
2280 \\
5016 \\
720 \\
2280 \\
5016\end{array}$ & $\begin{array}{l}3.2-3.3 \\
4.3-4.5 \\
7.8 \\
10.2-21.5 \\
10.5 \\
27.13 \\
46.2 \\
4.4-6.6 \\
10.9 \\
23.0\end{array}$ & $\begin{array}{l}0.068-0.070 \\
0.032-0.035 \\
0.031 \\
0.017-0.018 \\
0.25 \\
0.21 \\
0.161 \\
0.108-0.162 \\
0.084 \\
0.080\end{array}$ \\
\hline CDA 673 & $\begin{array}{l}\text { 95/Gas } \\
\text { 95/Liquid }\end{array}$ & $\begin{array}{r}836 \\
2334 \\
4392 \\
10,078 \\
720 \\
2280 \\
5015 \\
720 \\
2280 \\
5016\end{array}$ & $\begin{array}{l}1.1-1.7 \\
2.3 \\
2.5-3.4 \\
3.5-5.8 \\
7.9 \\
9.21 \\
17.9 \\
2.7-3.2 \\
8.4 \\
11.0\end{array}$ & $\begin{array}{l}0.025-0.040 \\
0.019-0.020 \\
0.012-0.015 \\
0.0071-.010 \\
0.217 \\
0.080 \\
0.071 \\
0.074-0.088 \\
0.073 \\
0.044\end{array}$ \\
\hline CDA 715 & $\begin{array}{l}\text { 95/Gas } \\
\text { 95/Liquid }\end{array}$ & $\begin{array}{r}836 \\
2334 \\
4392 \\
10,078 \\
720 \\
2280 \\
5015 \\
720 \\
2280 \\
5016\end{array}$ & $\begin{array}{l}7.0-10.0 \\
8.4-11.7 \\
7.6-10.5 \\
18.0-27.5 \\
19.2 \\
70.6 \\
64.3 \\
3.4-4.8 \\
17.7 \\
25.7\end{array}$ & $\begin{array}{l}0.015-0.021 \\
0.063-0.088 \\
0.031-0.042 \\
0.032-0.048 \\
0.47 \\
0.54 \\
0.22 \\
0.083-0.12 \\
0.14 \\
0.090\end{array}$ \\
\hline
\end{tabular}

*Ranges are for a maximum of three specimens. 


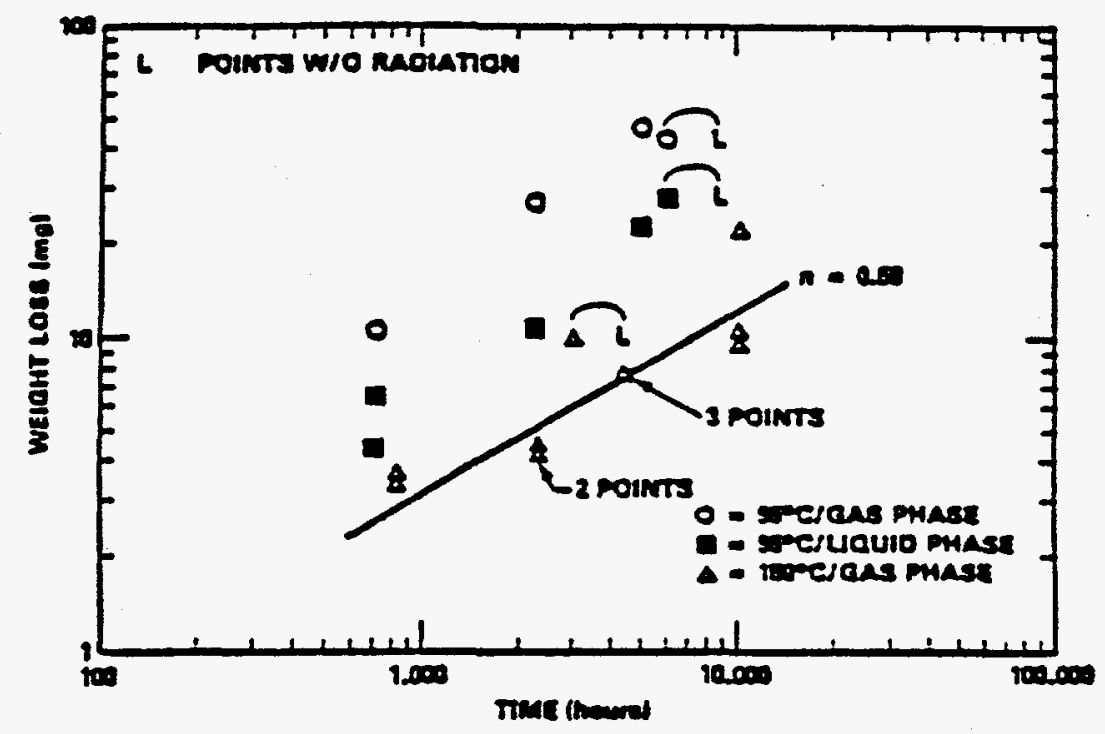

FIgure 5.6 Welght Loss Vs. TIme For CDA 101, Pure Copper Specimens. (Yunker-1986b)

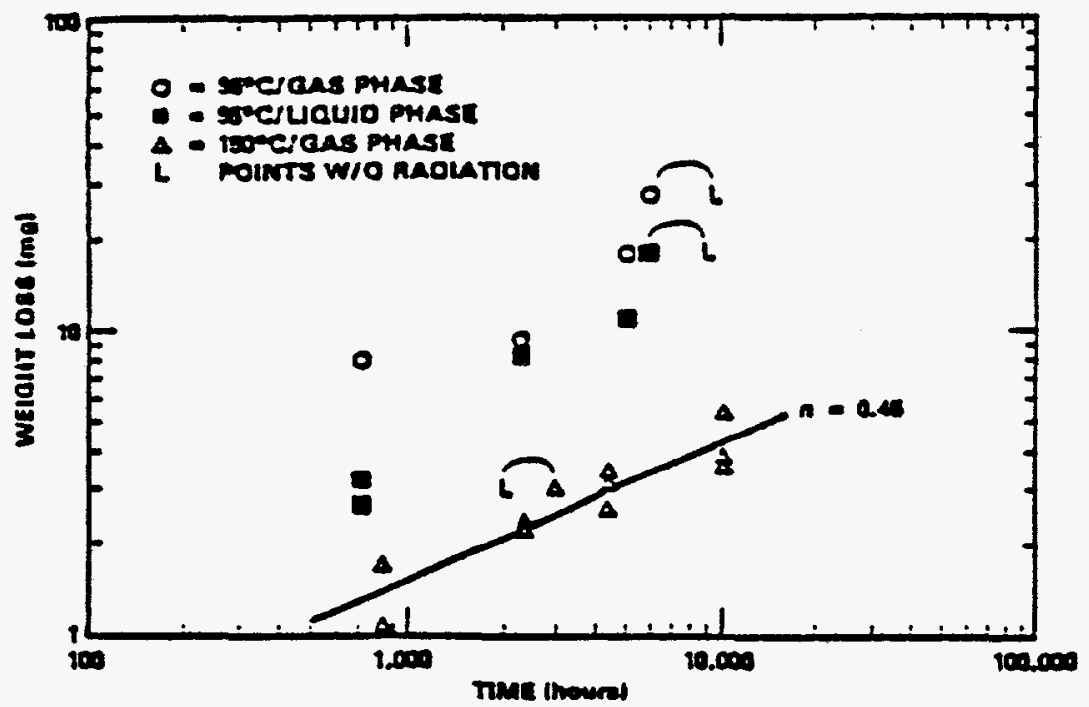

FIgure 5.7 Wolght Loss Vs. TImo For CDA 613, Alun Imun Bronzo Specimens. (Yunker-1986b) 


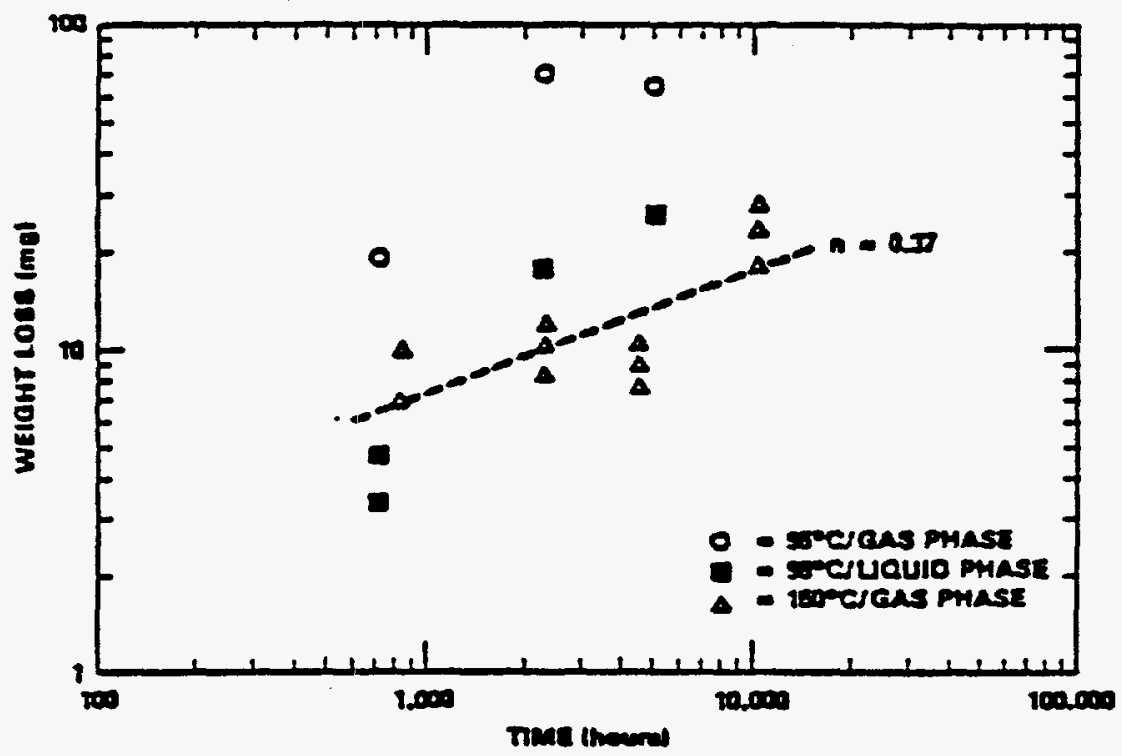

Figure 5.8 Welght Loss Vs. TIme For CDA 715, NIckel-Copper Specimens. (Yunker-1986b) 
formation of small water droplets on the specimens. It was speculated that corrosive species such as nitric acld concentrated in the droplets on the metal surface.

In an extension of the above work, Yunker-1986b reported on the result of 14 months of exposure under the above test condltions. As in the 7-month exposures, all these materlals experlenced pltting after 14 months of exposure and the pitting was most severe on CDA 715; filliform corrosion of CDA 613 also was reported for both test perlods. Evidence of dealloyIng of CDA 613 was found along the fuslon weld of CDA 613 tear drop specimens. Surprisingly, after 14 months of exposure, no evldence of crevlce corrosion was observed on the internal surfaces of the crevice specimen palrs or beneath the tightly fitted alumina support washers; the locallzed attack was confined to the free surfaces and beneath the loosely fitted alumina support washers.

Glass-1986a performed cyclic potent lodynamic polarlzation experiments on CDA 102 in concentrated J-13 water at $90^{\circ} \mathrm{C}$ with and without a radiation fleld. Results, given in Figure 5.9 (Acton-1986) indicate only a modest shift in the pitting parameters as a result of the radlation fleld. Based

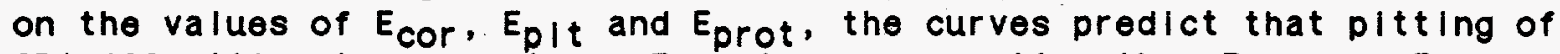
CDA 102 will not occur, I.e. Ecor is more negative than $E_{p r o t}$ or $E_{p \mid t}$.

Glass-1986a measured shifts in the free-corrosion potential of CDA 102 in $\mathrm{J}-13$ well water when specimens were Irradiated. The experiments were performed at $30^{\circ} \mathrm{C}$ in naturally aerated $\mathrm{J}-13$ well water with a cobalt 60 source at a radiation level of $3.3 \times 10^{6}$ Rads/hour. Typlcal results, given in figure 5.10 show a rapld transient potential shift of about $+100 \mathrm{mV}$ but this value decays within 150 minutes to less than $20 \mathrm{mV}$. The potentlal shift of about $20 \mathrm{mV}$ agrees well with the shifts measured by Glass-1986a in the potentlodynamic polarization studles discussed above. A potentlal shlft of the order of $100 \mathrm{mV}$ moves the free-corrosion potential to values near to the protection potentlal but it is questionable whether such a transient would actually inltiate pltting. In addition, if pits InItiated, they would be expected to repassivate once the potentlal dropped below the protection potential.

In related work, Glass-1986a evaluated the potentlal translents produced on CDA 102 when $\mathrm{H}_{2} \mathrm{O}_{2}$ was added to the $\mathrm{J}-13$ well water. A typlcal transient, shown In Figure 5.11 (Yunker-1986b) is very similar to the transients produced by the radiation fleld, prompting the authors to conclude that the primary influence of gamma radiation is to produce $\mathrm{H}_{2} \mathrm{O}_{2}$ and $\mathrm{OH}$ radical.

Comparison of the data presented above Indlcates that the results of the IImlted electrochemlcal studies and the exposure studies in a radiation fleld are not altogether consistent. There are several possible explanations for this inconsistency. First of all, much of the pitting observed In the exposures by Yunker-1986b occurred in the vapor phase; a condition not tested by Glass-1986a. Secondly, the potent lodynamlc polarization results do not necessarlly represent steady-state condltions. The values of $E_{\text {prot }}$ or $E_{\text {plt }}$ could move in the negative direction with time while $E_{\text {cor }}$ could shift in the positive direction. In any case, these results demonstrate that care should be taken In interpreting the results of the electrochemlcal studies. 


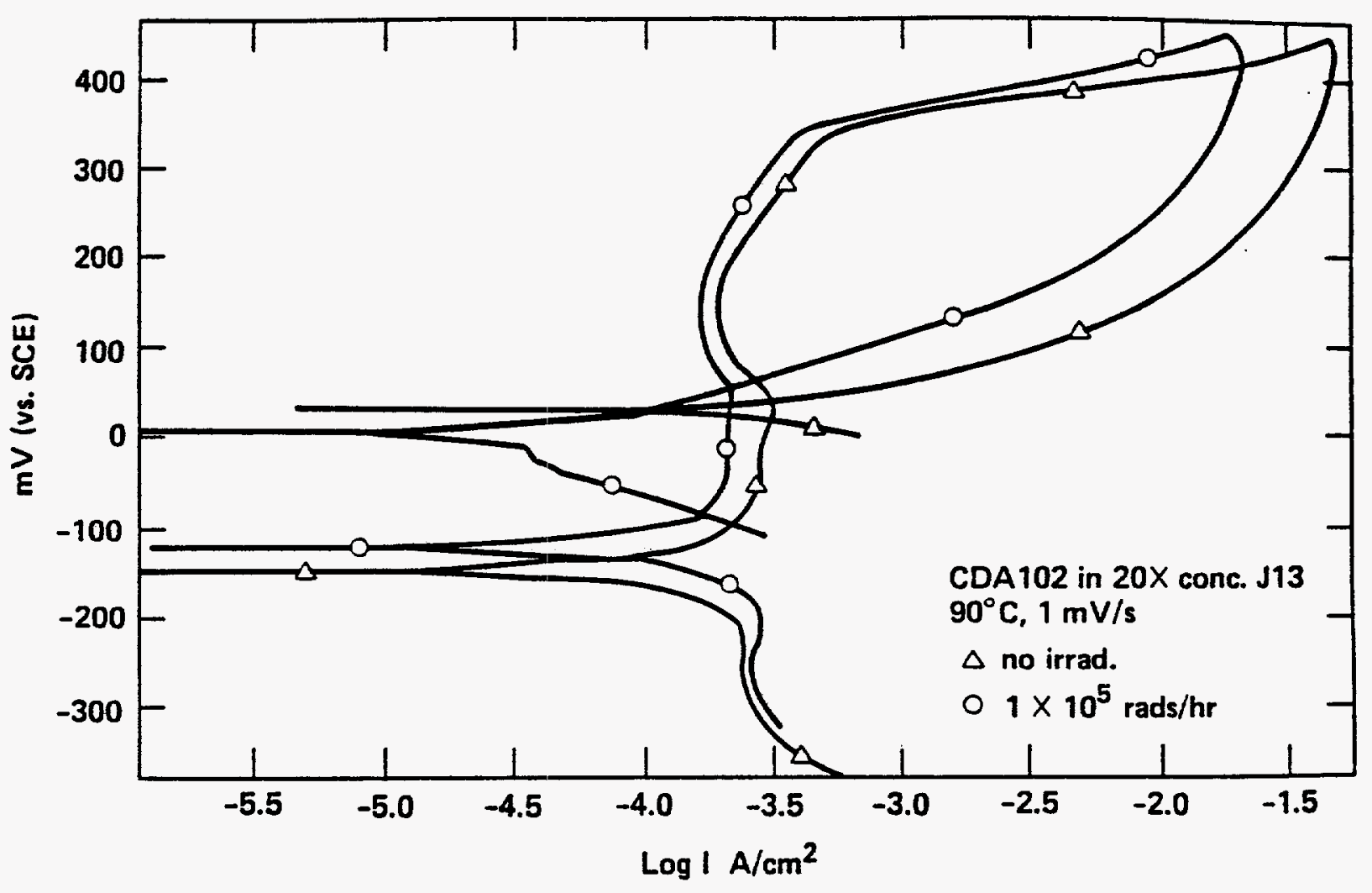

Flgure 5.9 Polarization Curves For CDA 102 in $20 \mathrm{~J}-13$ water At $90^{\circ} \mathrm{C}$ Both out of And In Gamma Radiation Fleld. (Acton-1986) 


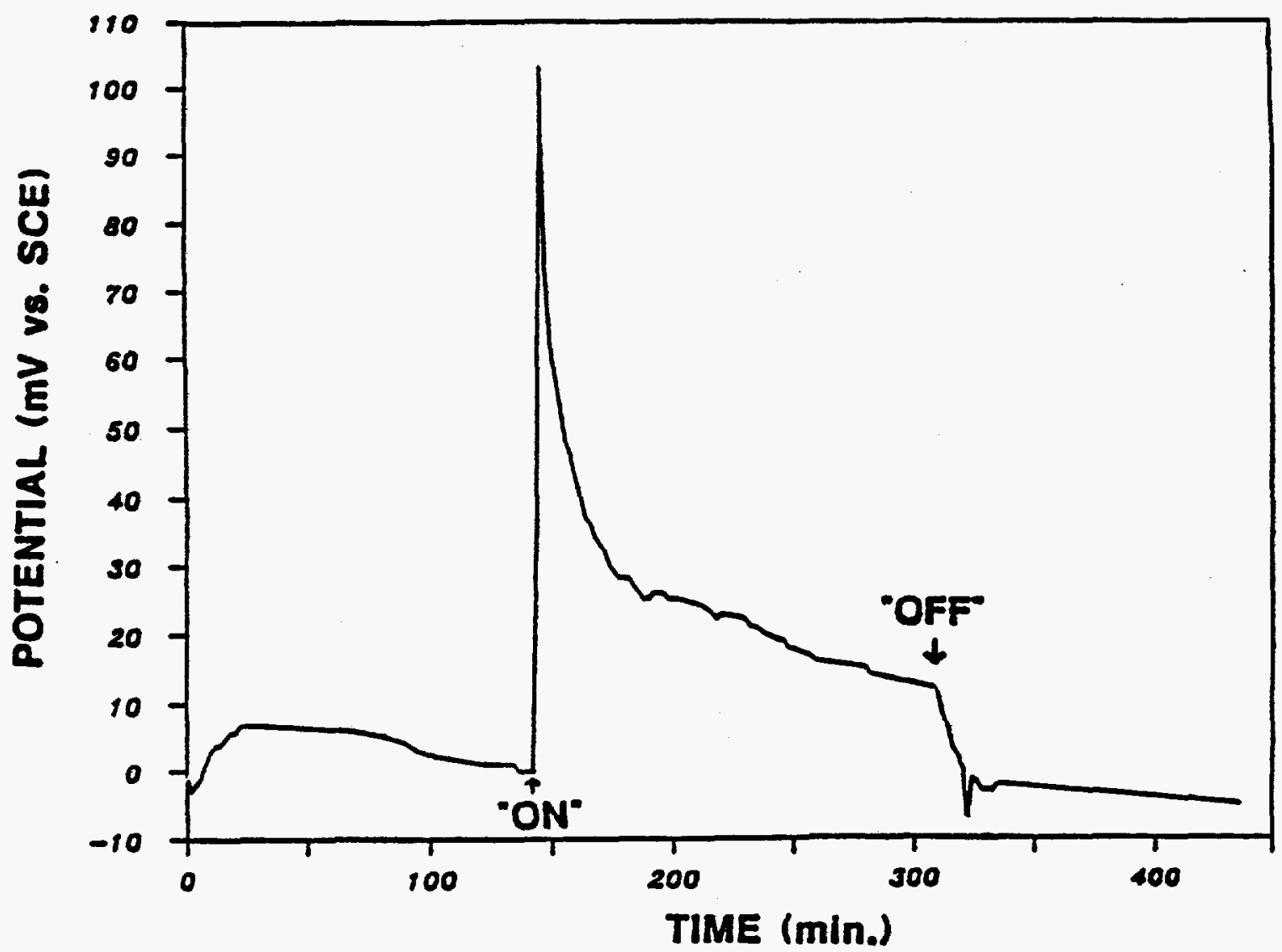

Flgure 5.10 Corrosion Potentlal Behavior For CDA 102 Copper Irradiated In J-13 Well Water At $3.3 \mathrm{Mrad} / \mathrm{hr}$. (Glass-1986a) 


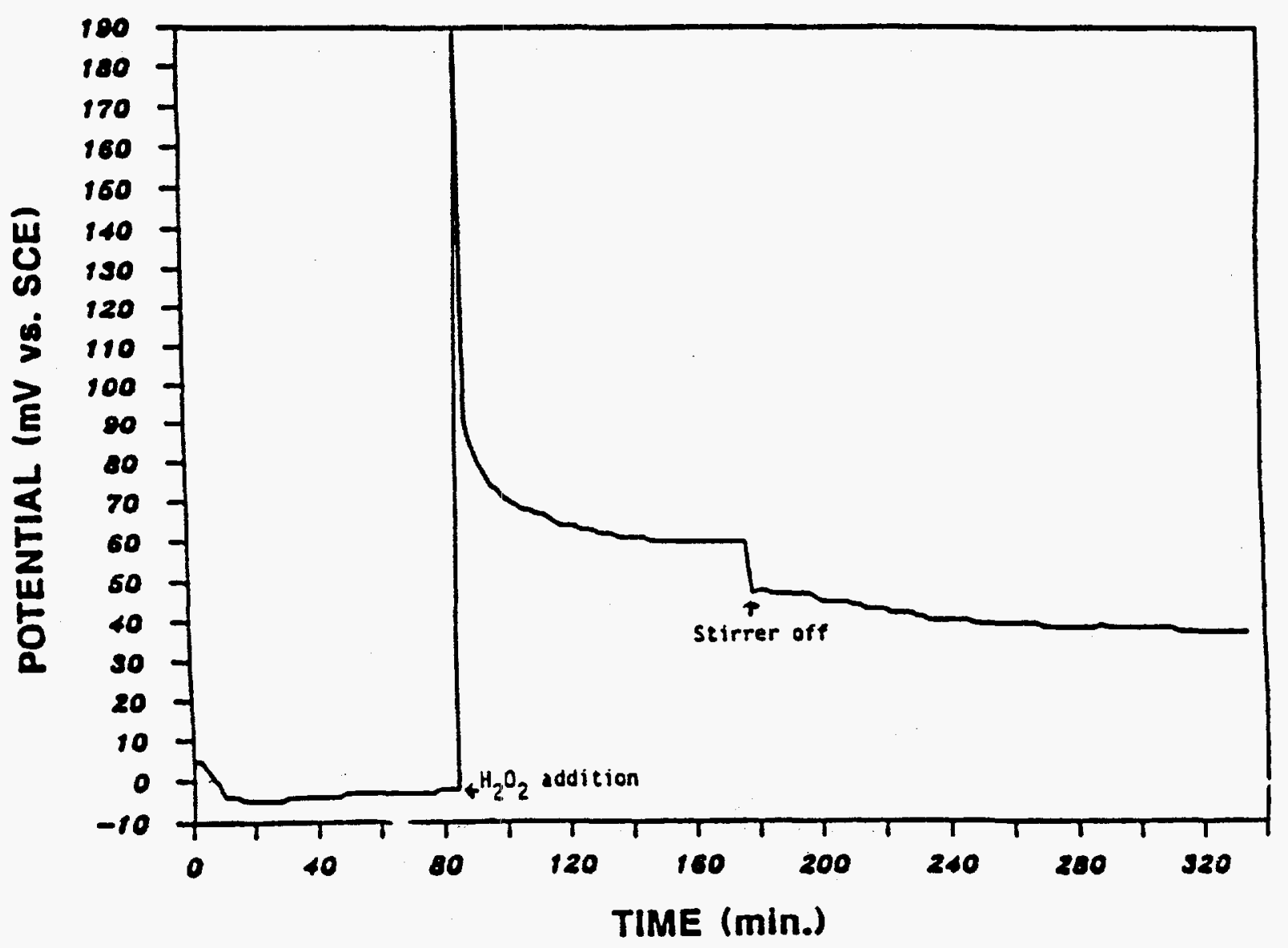

Figure 5.11 Response of The Corrosion Potentlal For CDA 102 Copper In Irradlated J-13 Well Water To Whlch One Drop of $30 x \mathrm{H}_{2} \mathrm{O}_{2}$ Solution Was Added, Corresponding To A Solution Concentration of $0.5 \mathrm{mM}$. The Solution Was StIrred UntII Indlcated on The Fl gure. (Glass--1986a) 


\subsubsection{Stress Corrosion Cracking ( $S C C$ )}

Yunker-1986a exposed tear drop shaped stress corrosion specimens of CDA 102, CDA 613 and CDA 715 to three simulated Tuff repository environments in the presence of a radlation fleld. The tear drop specimens were prepared by the single stressing method according to ASTM G30-79, and the specimen ends were fusion welded. The 3 environments were, as descrlbed above, aerated $\mathrm{J}-13$ well water at $95^{\circ} \mathrm{C}$, water saturated air at $95^{\circ} \mathrm{C}$ and alr-water vapor at $150^{\circ} \mathrm{C}$. A gamma fleld of $1 \times 10^{5} \mathrm{R} /$ hour was used in the study. Following exposure, the specimens were examined optically and by means of dye penetrants.

Acton-1986 reported on the results of 6-month exposures. No evidence of cracking was found visually or by means of dye penetrant for any of the alloys evaluated. Metallographic examinations of the specimens had not been completed at the time of reporting.

In subsequent work, Yunker-1986b reported on the results of 14 month exposures under the above test conditions. Again, there was no evidence stress corrosion cracking, based on optical and dye-penetrant examination of the tear-dropped specimens following exposure. 


\section{MICROBIOLOGICAL EFFECTS ON CORROSION}

No data were found in the llterature on microblologlcal effects on corrosion in the Tuff repository. Apparently, this area has not been given attention because of the high radlation flelds and elevated temperatures anticlpated in the repository following closure. However, after several hundred years, conditions in the repository may be favorable for the growth of colonies of mlcrobes that are detrimental to the performance of the waste contalner (seo section 2.4 for addltional detalls on possible microbes).

\section{$6.1 \mathrm{Fe}-\mathrm{Cr}-\mathrm{NI}$ Alloys \\ 6.1.1 General Corrosion}

General corrosion rates for stalnless steel are almost always negliglble under passive conditlons; a good example belng the low general corrosion rates reported for Type 304L stainless steel in J-13 well water. Where locallzed forms of attack occur, finlte general corrosion rates may be reported since the overall welght change of the metal may be increased by the locallzed attack. Thus, Mlcroblological Induced Corrosion (MIC) of stalnless steels almost always is manifested as a locallzed form of attack and may cause some moderate increase in measured general corrosion rates. However, the emphasis of the research and testing has been on locallzed forms of corrosion.

\subsubsection{Locallzed Corrosion}

While no research apparently has been performed on locallzed MIC of stainless steels in a Tuff repository, numerous instances of pltting and crevice corrosion of stainless steels have been attrlbuted to MIC. Table 6.1 Is a summary of just a few case historles reported in the open literature. The data show that severe pltting and crevice corrosion of stalniess steels can occur in the presence of microbes in waters containing very low concentrations of deleterlous specles such as $\mathrm{Cl}$. An interesting example is the case reported by stoecher-1986 of pltting and transgranular stress corrosion cracking (T-SCC) of Type 304 stalnless steel in a hot demineralized water tank. The tank was operated at temperatures ranging from 75$150^{\circ} \mathrm{C}$. The water contalned low levels of aggressive specles such as $\mathrm{Cl}$ as shown in Table 6.2 (Stoecher-1986). Nevertheless, severe pltting and SCC occurred in a Type 304 stainless steel process tank containing this water. The locallzed corrosion was assoclated with rust colored nodules (brown/ black at metal surface) that were found to contain the bacterla Bacillus Spp. The nodules also were found to be enrlched in $\mathrm{Cl}, \mathrm{S}, \mathrm{SI}$ and $\mathrm{Cr}$. It was speculated that the mlcrobes promoted the enr lchment of deleterlous specles leading to the fallures; see sectlon 6.1 .3 for additional detalls.

On the other hand, Pope-1982 reported on the locallzed corrosion and T-SCC of Type 304L stalnless steel beneath blofilms in which IIttle Cl was found. The fallures occurred in heat exchanger tubes exposed to fresh $r$ Iver water. Thus, some microbes apparently are capable of promoting localized corrosion in the absence of a concentration mechanism for chlorldes. 
Table 6.1 Summary of Several Case HIstorles of MIC Reported In The Open Literature.

\begin{tabular}{|c|c|c|c|c|c|}
\hline Alloy & Enviromment & Fallure Mode & Deposites & Mlerobe & Reference \\
\hline 304 ss & Fresh Water & Type II Plte & & Not Identiffed & Stoecker-1984 \\
\hline Monel 400 & $\begin{array}{l}\text { Troated Froeh } \\
\text { service Water }\end{array}$ & IGA, Dealloying & Green, so, Alch & $\begin{array}{l}\text { Not Identllled } \\
\text { peoudomonas suepected }\end{array}$ & stoecker-1984 \\
\hline 30435 & Atver Water & Crevice Corroeton & $\begin{array}{l}\text { Drown, Low Cl } \\
\text { Hlgh Fe }\end{array}$ & Peoudononas & Tatnal1-1981b \\
\hline 30453 & $\begin{array}{l}\text { Chlorinated Potable } \\
\text { Woll Water }\end{array}$ & $\begin{array}{l}\text { Type I Pite } \\
\text { At Wolde }\end{array}$ & $\begin{array}{l}\text { Red-brown, HIgh } \\
\text { Fe Mn } \mathrm{Cl}\end{array}$ & $\begin{array}{l}\text { Desulfovibrto } \\
\text { Sphaerottlus } \\
\text { Gelltonella }\end{array}$ & Tetnal1-1981b \\
\hline 304 ss & Lake Water & $\begin{array}{l}\text { Type I Plts } \\
\text { with IGA }\end{array}$ & $\begin{array}{l}\text { Bleck Tuboreles } \\
\text { With Highs }\end{array}$ & SRB: & Puckor tuo-1983 \\
\hline 30453 & $\begin{array}{l}\text { Hot }\left(76-150^{\circ} \mathrm{C}\right) \\
\text { Dominerallzed Water }\end{array}$ & $\begin{array}{l}\text { Type I Ple: } \\
\text { T-scc }\end{array}$ & $\begin{array}{l}\text { Auct colored with Brown- } \\
\text { Bleck At Metel surface } \\
\text { Elovated S Cl }\end{array}$ & Baclllue SPP & stoecker-1986 \\
\hline $\begin{array}{l}\text { 304L: } \\
\text { 316L SS }\end{array}$ & $\begin{array}{l}\text { Woll Wator } \\
\text { (200 ppm CI) }\end{array}$ & $\begin{array}{l}\text { Type II Pite } \\
\text { At wolds }\end{array}$ & $\begin{array}{l}\text { Aod-Browm, HIgh } \\
\text { Fo, Mn el }\end{array}$ & $\begin{array}{l}\text { Gall lonolia } \\
\text { SIderocapes }\end{array}$ & Kobrtn-1986 \\
\hline 30433 & Woll Wator & $\begin{array}{l}\text { Type II Pits } \\
\text { T-scc }\end{array}$ & $\begin{array}{l}\text { Fod huet } \\
\text { Bleck Dopoetls }\end{array}$ & SAB Fo Bactorta & Kobrin-1988 \\
\hline 31653 & well Wator & $\begin{array}{l}\text { Type II Pite } \\
\text { At Wolds }\end{array}$ & Aod-Brown & Not Identlfted & Kobrin-1988 \\
\hline 30458 & Alver Water & $\begin{array}{l}\text { Types } t \text { \& It } \\
\text { T-sec At Wolds }\end{array}$ & Aod-Brown & Not Identiflod & Xobrln-1988 \\
\hline 31638 & Miver Water & Typo 11 Pite & Rod-drown steins & Not Identifled & Kobr In-1986 \\
\hline
\end{tabular}

Type 1 pite - Hemlephericel.

Typo II Plts - Belloon shaped Plte.

IGA - Intergranular Attack.

T-sce - Tranegranular strace corroelon cracking. 
Table 6.2 Water Analyses. (Stoecker-1986)

\begin{tabular}{|c|c|c|c|}
\hline Date sample taken & 1982 & 1983 & 1984 \\
\hline Total magnesium hardness as $\mathrm{CaCO}_{3}$, PPM & 0.10 & 0.5 & 0.13 \\
\hline Total hardness, sum of ions, $\mathrm{CaCO}_{3}, \mathrm{PPM}$ & 0.15 & 1.0 & 0.28 \\
\hline Total copper as Cu, PPM & 0.05 & 0.05 & 0.05 \\
\hline Total calcium hardness as $\mathrm{CaCO}_{3}$, PFM & 0.14 & 0.5 & 0 \\
\hline Sulfate and sulfite as $\mathrm{SO}_{4}, \mathrm{PPM}$ & - & 32 & 29 \\
\hline Specific conductivity, UMHOS & 219 & 190 & 197 \\
\hline $\mathrm{pH}$ & 6.2 & 5.9 & 6.1 \\
\hline Chloride as Cl, PPM & 24 & 19 & 21 \\
\hline Alkalinity, $\mathrm{M}$, as $\mathrm{CaCO}_{3}$, PPM & 16 & 5 & 14 \\
\hline Alkalinity, P, as $\mathrm{CaCO}_{3}, \mathrm{PPM}$ & 0 & 0 & 0 \\
\hline Total iron as Fe, PPM & 0.05 & 0.06 & 0.05 \\
\hline Sodium as $\mathrm{Na}, \mathrm{PPM}$ & 45 & 41 & 37 \\
\hline Silica as $\mathrm{SiO}_{2}$, PPM & - & 13 & 15 \\
\hline Phosphate, total as $P O_{4}, P P M$ & - & 0.4 & - \\
\hline Phosphate, total inorganic, as $P O_{4}$ PPM & - & 0.2 & - \\
\hline Phosphate, ortho-, as PO, FPM & - & 0.2 & - \\
\hline
\end{tabular}

Reprinted by permission of the National Assoclation of Corrosion Engineers, publisher of Materlals Performance. 


\subsubsection{Stress Corrosion Cracking (SCC)}

Several reported Instances of SCC in natural waters have been attributed to MIC. Kobrin-1986 reported on the occurrence of transgranular SCC of a Type 304 stalnless steel vessel in a chemlcal plant In Texas. Prlor to the fallure, the vessel had been hydrotested wlth untreated well water. Following testing, no speclal effort was made to remove the water or dry the system. Several months after the hydrotest but prlor to belng placed in service, leaks developed in the vessel. An inspectlon of the vessel Indicated the presence of plts and cracks under rust colored nodular deposits, primarlly along welds. The cracks were branched, transgranular and typlcal of Cl-sCC of austenitlc stainless steels. Both Iron bacterla and SRBs were found in deposits in the system and significant concentrations of $\mathrm{Cl}$ and $\mathrm{S}$ were found in the deposits. The cracking and pltting were attrlbuted to concentration of $\mathrm{Cl}$ by the bacterla. An unusual aspect of the fallure is the occurrence of cracking at temperatures below $60^{\circ} \mathrm{C}$.

Stoecher-1986 reported on the occurrence of T-SCC of Type 304 stainless steel In high temperature deminerallzed water. A storage tank, which operated at $75-150^{\circ} \mathrm{C}$ was installed in 1976 and showed evidence of pitting during the first Inspection in 1981. The tank falled and was replaced in 1984. Water treatment consisted of injecting mldwestern well water with chlorine to eliminate microblal growth. The water was held in a residence tank from which it was pumped through act Ivated carbon fliters and hydrogen resin fliters to a degassifler tower. The pH was adjusted with caustlc soda after degassiflcatlon, and then the water was pumped through sodlum zeollte softeners and to the tank. Table 6.2 shows typlcal chemical analyses for 1982, 1983, and 1984. Note the low concentration of deleterlous specles such as $\mathrm{Cl}$.

A metal lographlc examination of the tank Indicated the presence of T-SCC In the heat affected zone (HAZ) of the seam welds In the tanks. The cracking was assoclated with nodular deposits that were found to contain Baclilus Spp. All analyses were negatlve for SRBs. The cracking appeared to Inltlate intergranularly in the HAZ and then propagate transgranularly. An electron probe microanalysis (EPM) of the cracks Indicated elevated levels of $\mathrm{S}$ and $\mathrm{Cl}$; see Flgure 6.1 (Stoecker-1986). As in the prevlous fallure, It was concluded that the T-SCC occurred as a result of concentration of $\mathrm{Cl}$ by the microbes.

There are two interesting aspects of this fallure with regard to the Tuff repository. First of all, It demonstrates that $\mathrm{Cl}-\mathrm{SCC}$ can occur in the presence of microbes even when the water is low in $\mathrm{Cl}$. Secondly, this fallure demonstrates that some microbes can prollferate at high temperatures $\left(75-150^{\circ} \mathrm{C}\right)$.

In a third incldence of MIC, Pope-1982 reported on the SCC of Type 304L stainless steel tubes in a heat exchanger that operated in water from the Savannah river. Typlcal water samples are glven in Table 6.3 (Pope-1982). The heat exchangers also were blocide treated with $\mathrm{Cl}_{2}$ to glve a residual level of $1 \mathrm{mg} / \mathrm{L}$ in the water for 1 hour per day.

During short refueling outages, the heat exchangers were maintained full of river water while they were drained for longer outages. Analyses Indicated low levels of Cl in the cooling water; see Table 6.3. Desplte the purity of the cooling water, problems of pltting and SCC have occurred 


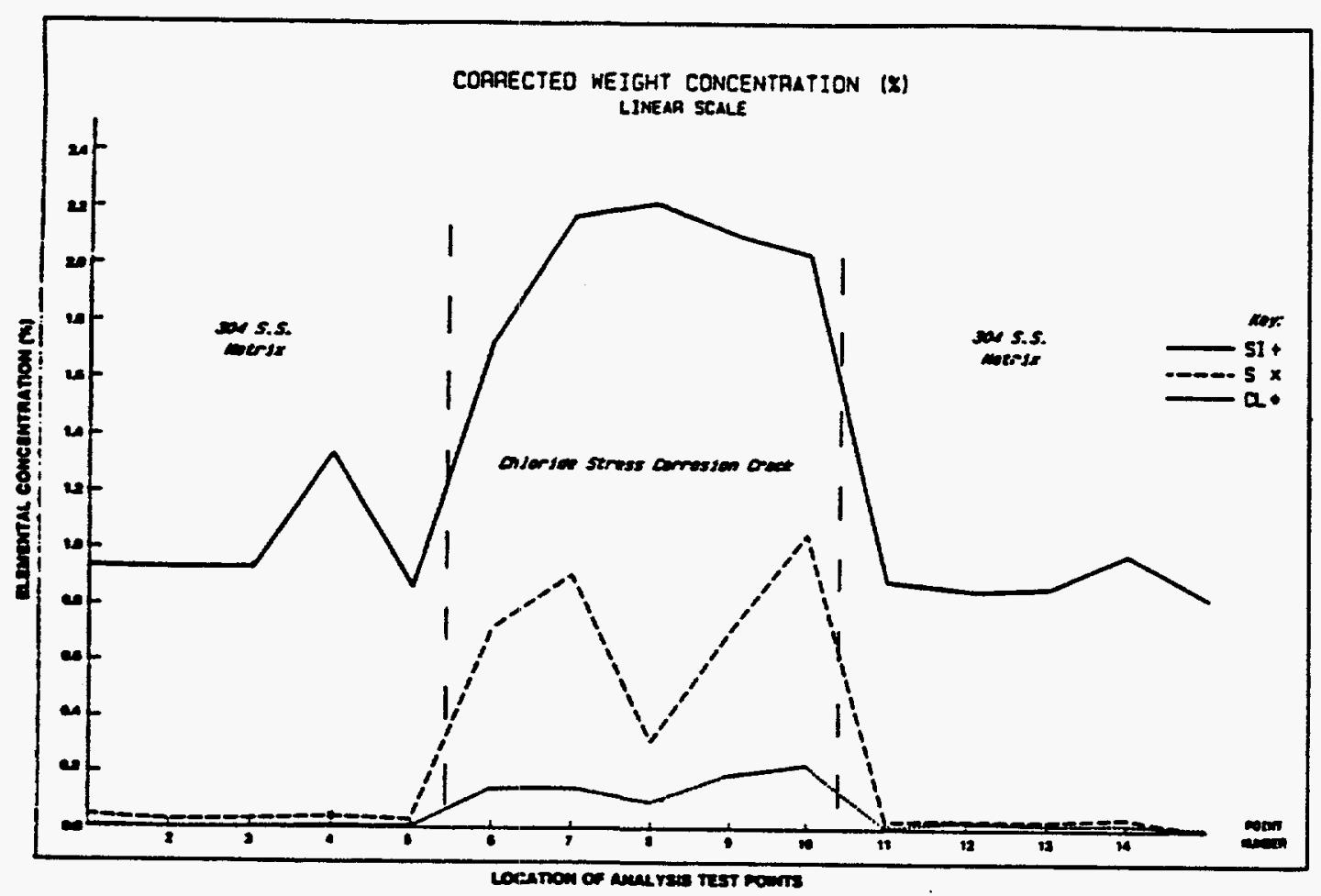

Flgure 6.1 Electron Probe Microanalyses Elemental Plots Across A Typlcal Crack In A Rough Sanded Cross-Sectional PItted Specimen From The Tank Mall. Top LIne Depicts Sill con Content, Mlddle Line Deplets Su: fur Content And Botton Line Depicts Chlor Ine Content. (Stoecker-1986)

Reprinted by permission of the National Assoclation of Corrosion Englneers, publisher of Materlals Performance. 
Table 6.3 Composition of Water Samples From Heat Exchangers. (1) (Pope-1982)

\begin{tabular}{lccc}
\hline & & & \\
Chemical Parameters & Influent & Effluent & Drainage \\
\hline Total Carbon & $9.6 \pm 0.2$ & $9.9 \pm 0.2$ & $9.4 \pm 0.2$ \\
Total Inorganic Carbon & $4.5 \pm 0.4$ & $4.4 \pm 0.4$ & $4.8 \pm 0.4$ \\
Total Dissolved Carbon & $8.4 \pm 0.1$ & $9.3 \pm 0.1$ & $9.1 \pm 0.2$ \\
Dissolved Inorganic Carbon & $3.8 \pm 0.4$ & $4.3 \pm 0.4$ & $4.6 \pm 0.4$ \\
$\mathrm{NO}_{3}(\mathrm{~N})$ & $0.496 \pm 0.006$ & $0.513 \pm 0.006$ & $0.629 \pm 0.006$ \\
$\mathrm{NO}(\mathrm{N})$ & $0.022 \pm 0.0003$ & $0.023 \pm 0.0003$ & $0.076 \pm 0.0003$ \\
$\mathrm{NH}(\mathrm{N})$ & $0.245 \pm 0.005$ & $0.236 \pm 0.005$ & $0.272 \pm 0.004$ \\
$\mathrm{Kjel}(\mathrm{N})$ & $0.503 \pm 0.008$ & $0.532 \pm 0.008$ & $0.556 \pm 0.010$ \\
$\mathrm{Ortho} \mathrm{P}$ & $0.042 \pm 0.001$ & $0.035 \pm 0.001$ & $0.018 \pm 0.001$ \\
$\mathrm{Total} \mathrm{P}$ & $0.099 \pm 0.001$ & $0.099 \pm 0.001$ & $0.099 \pm 0.001$ \\
$\mathrm{Al}$ & $0.027 \pm 0.002$ & $0.005 \pm 0.002$ & $0.034 \pm 0.003$ \\
$\mathrm{Ca}$ & $3.7 \pm 0.1$ & $3.7 \pm 0.1$ & $4.1 \pm 0.1$ \\
$\mathrm{Cl}-$ & $6.50 \pm 0.25$ & $6.25 \pm 0.25$ & $6.5 \pm 0.25$ \\
$\mathrm{Cr}$ & $<0.002$ & $<0.002$ & $<0.002$ \\
$\mathrm{Fe}$ & $0.087 \pm 0.002$ & $0.077 \pm 0.002$ & $0.079 \pm 0.002$ \\
$\mathrm{Mg}$ & $0.00129 \pm 0.00001$ & $0.00129 \pm 0.00001$ & $0.00136 \pm 0.00001$ \\
$\mathrm{Mn}$ & $0.036 \pm 0.005$ & $0.035 \pm 0.005$ & $0.034 \pm 0.005$ \\
$\mathrm{Na}$ & $9.8 \pm 0.3$ & $7.6 \pm 0.3$ & $7.9 \pm 0.3$ \\
$\mathrm{Ni}$ & $<0.003$ & $<0.003$ & $<0.003$ \\
$\mathrm{Si}$ & $5.1 \pm 0.3$ & $5.1 \pm 0.3$ & $4.9 \pm 0.3$ \\
$\mathrm{~S}=$ & $<0.01$ & $<0.01$ & $<0.01$ \\
$\mathrm{SO}$ & $9.9 \pm 0.9$ & $9.7 \pm 0.9$ & $8.9 \pm 0.9$ \\
$\mathrm{Total} \mathrm{S}$ & 3.3 & 3.2 & 3.0 \\
\hline
\end{tabular}

(1)All values are given in $\mathrm{mg} / \mathrm{L} \pm 1$ standard deviation.

Reprinted by permission of the Natlonal Association of Corrosion Englneers, publisher of Materlals Performance. 
In the system, over the length of the tubes. A wide varlety of mlcroorganisms was found in flims on the heat exchanger tubes. High levels of $\mathrm{Fe}, \mathrm{Mn}$ and Si also were found on the tubes. However, the authors falled to detect signiflcant quantities of $\mathrm{Cl}$ in the deposits. Thus, It appears that microbes may be ablo to promote SCC In the absence of signiflicant concentrations of chlorldes.

\subsection{Cu-Base Alloys}

\subsubsection{General Corrosion}

As is the case for stainless steels, MIC of copper-base alloys is generally manlfested as locallzed fallure modes such as pltting. However, under extreme condltions, high rates of general corrosion have been assoclated wIth MIC. One utllity reported rapld general wastage of $\mathrm{Cu}-10 \mathrm{NI}$ heat exchanger tubes in Hudson River water, Mark-1986. The fallures were attributed to sulfides produced by SRBs.

\subsubsection{Localized Corrosion}

Cases of MIC of copper base alloys are more poorly documented than those for stalniess steels. Pope-1983 attrlbuted thls to the fact that many people have belleved copper lons and salts are lethal to most mlcroorganisms. Nevertheless, cases of MIC have been reported in the IIterature. Grant-1924, Eengough-1924, and Rogers-1948 reported pltting of copper alloys under microblal colonles. More recently, Alanis-is86 reported on the MIC fallures of underground brass $(91.6 \mathrm{Cu}-8.2 \mathrm{Zn})$ plpes. The plpes perforated in less than two years in clay soll in a subtropical c!lmate. SREs were found in adherent deposits on the plpe which were associated with areas of severe locallzed attack.

In marine applications, It is well establlshed that sulfldes generated by SRBs in polluted water will promote pltting fallures of copper base alloys Beavers-1980. The brasses and copper-nlckel alloys appear to be partlcularly susceptlble to sulfide attack and no copper base alloy appears to be Immune to pltting by sulfide. Sato-1976 and Sato-1978 showed that an aluminum bronze, AP Bronze (Cu-6Sn-iA1) is the most resistant of the copper base alloys. Data by Gudas -1978 showing the effect of sulfice concentration on locallzed attack of copper-nlckel alloys are given in Figure 6.2 (Gudas-1978). These data show that very low concentratlons of sulfide, $<0.05 \mathrm{ppm}$, wlll promote attack of these alloys.

By-products and decay products of organlsms also will promote locallzed attack of copper-base alloys. Rogers-1948 evaluated the effect of a varlety of microorganisms and of their by-products on the corrosion of copper-base alloys and found in all cases that locallzed attack was promoted.

1 Mark-1986 - Private communication, dated May, 1986. 


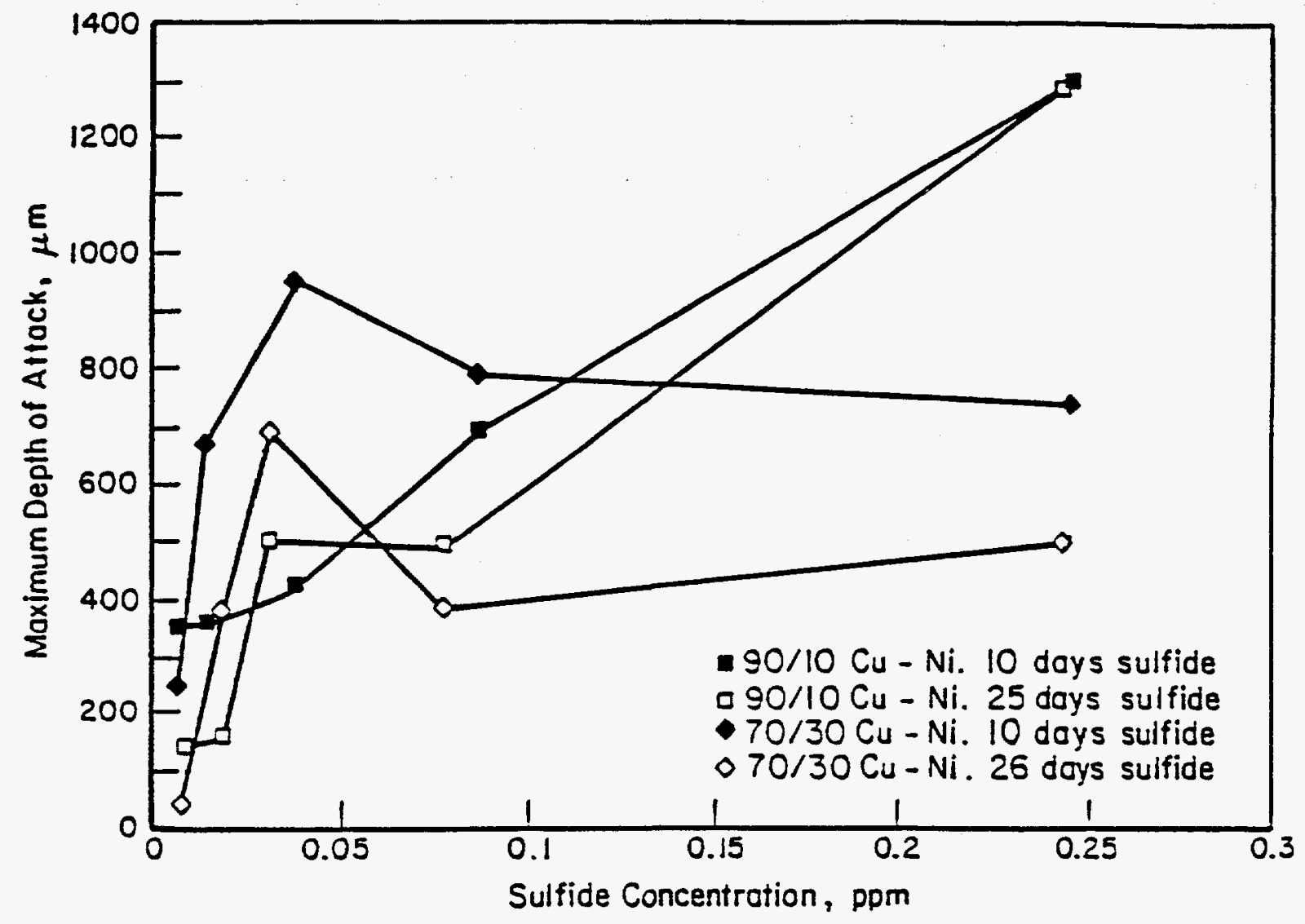

Figure 6.2 The Effect of Sulfide concentration of Flowing seawater (2.4 $\mathrm{m} / \mathrm{s}$ ) On PItting of Copper-10 NIckel And Copper-30 NIckel. (Gudas-1978)

Reprinted by permission of the National Association of Corrosion Englneers, publisher of Corrosion 1978. 


\subsection{3 stress Corrosion Cracking (SCC)}

No reported cases of MIC Induced SCC of copper-base alloys were found In the Ilterature. On the other hand, corrosion decay and by-products of organ Isms are establlshed cracking agents for copper-base al foys. These Include nitrites and ammonla. In this regard, Beavers-1979 suspected that mlcroorganlsms played a role In the T-Scc of Admiralty brass condenser tubes in Hudson River water. It was speculated that nitrites were generated by microbial action beneath deposits on the 10 of the tubes.

1 Beavers-1979 - Beavers, J. A., Unpubl Ished work performed at Battelle Columbus Division. 


\section{DISCUSSION AND CONCLUSIONS}

\subsection{Fe-Cr-NI Alloys}

The austenitlc stainless steels exhlblted excellent resistance to general corrosion In J-13 well water and In steam. Thlckness losses of less than $1 \mathrm{~mm}$ are est Imated in 1,000 year exposure in a Tuff repository. Although the data are more IImlted on nlckel alloys such as Alloy 825 , these alloys also would be expected to perform well from the standpolnt of general corrosion in the repository environment. General corrosion rates increased moderately as the result of the addition of a radiation fleld, temperature increases, or concentration of the groundwater due to thermal effects. Thus, from the standpolnt of general corrosion, the $\mathrm{Fe}-\mathrm{Cr}-\mathrm{NI}$ alloys are well sulted for the Tuff repository.

However, Fe-Cr-NI alloys are selected because of thelr resistance to general corrosion and rarely fall in service by this mode. More commoniy, these alloys fall by locallzed forms of corrosion such as pltting, crevlce corrosion, or stress Corrosion Cracking (SCC).

The candldate $\mathrm{Fe}-\mathrm{Cr}-\mathrm{NI}$ alloys do appear to be resistant to pltting corrosion In J-13 well water at $50-100^{\circ} \mathrm{C}$. Based on electrochemlcal studies, only a slight Increase in pltting susceptlblilty was observed with increasing temperature over this range. Some silght susceptlbility to crevice corrosion was observed for all of the alloys, Including Alloy 825, In long term ( 1 year) exposures in $\mathrm{J}-13$ well water at temperatures between 50 and $100^{\circ} \mathrm{C}$. However, it is not clear whether this behavior would compromise the contalner.

The radiation fleld has a number of deleterlous effects on potentlal pltting performance of the Fe-Cr-NI alloys. Results of electrochemical studies Indicate that a gamma radiation fleld moves the corrosion potentlal in the positive direction in $\mathrm{J}-13$ well water, Increasing the IIkellhood for pltting. While Ecor values for Type 304L stainless steel In $J-13$ well water, In one study, were more negative than $E_{p}$ It values, then were more positlve than Eprot values, predicting that once a pit Initlates, It wIII not spontaneously repassivate. Results of long term exposures of $\mathrm{Fe}-\mathrm{Cr}-\mathrm{Nl}$ alloys in a radlation fleld, while not Indicating severe pltting, showed evidence of passive fllm breakdown. Specimens of Type 304L and Type $316 \mathrm{~L}$ stainless steel exposed in the vapor phase at $50-90^{\circ} \mathrm{C}$ above $\mathrm{J}-13$ well water exhlblted patches of red-brown oxide, Indicat Ive of passive film breakdown. Incoloy Alloy 825 would be expected to be relatively more resistant to pltting and crevice corrosion in these environments because of the high molybdenum content.

Results of analyses of $\mathrm{J}-13$ well water following exposure to gamma radlatIon also suggests that the radlation may deleterlously alter the environment. The generation of oxldizing species such as $\mathrm{H}_{2} \mathrm{O}_{2}$ is potentlally deleterlous since these specles move the corrosion potential in the positive directlon, Increasing the likellhood of pltting as descrlbed above. The radiation fleld also appears to greatly decrease the concentration of some beneficlal passivating specles in solution such as bicarbonate. While radlation also decreased the concentration of deleterlous specles such as $\mathrm{Cl}$, the decrease in concentration of beneficlal specles was much greater. The net effect is that, in the presence of a solution concen- 
tration mechanism such as local bolling, the groundwater may become depleted in passlvating agents leading to a higher probabllity of locallzed forms of corrosion.

The role of microbes in the performance of a austenitic stainless steel waste contalner has not been considered in any great detall. While it is unlikely that mlcrobes will play a role durlng the early life of the repository when radiation flelds and temperatures are $\mathrm{high}$, mlcrobes may affect the long term release rate of the repository after the thermal. perlod. Mlcroblological Induced Corrosion (MIC) of stainless steels is a serlous problem in groundwaters, surface waters and underground environments.

Probably the most serious problem for the austenitlc stainless steels in the Tuff repository is their poor resistance to SCC. While Type 304L and $316 \mathrm{~L}$ stalniess steels were found to be reslstant to SCC in J-13 well water and In thermally concentrated J-13 well water, cracking was observed In the vapor phase above $J-13$ well water in the presence of a radlation fleld. Thls fallure was transgranular and occurred In Type 304L stainless steel under optimum metallurgical conditlons. The performance of an actual contalner could only be expected to be worse as a result of fabrlcation and deleterlous alterations in the metallurgy such as low temperature sensitization. Indeed, much more severe cracking was observed in sensitized specimens. Unless this observation can be shown to be in error, it is the opinion of Cortest that the austenltic stainless steels should be eliminated from conslderation as contalner materials. On the other hand, Incoloy Alloy 825 would be expected to be more resistant to Transgranular stress Corrosion Cracking (T-SCC) In the Tuff repository environment because of its higher nickel content.

\subsection{Cu-Base Alloys}

The copper-base alloys exhlblted low to moderate rates of general corrosion in $\mathrm{J}-13$ well water and wet steam at $100^{\circ} \mathrm{C}$ as well as in dry steam at $150^{\circ} \mathrm{C}$. General corrosion rates of copper base alloys tended to Increase with Increasing temperature and were higher in the concentrated well water. CDA 102 exhlblted the highest corrosion rates, approaching 10 $\mathrm{m}$ Ils per year, in $100 \mathrm{X} \mathrm{J}-13$ well water at $80^{\circ} \mathrm{C}$. This corresponds to a thlckness loss of 10 -Inches in 1000 years which is unacceptable for a waste container. CDA 715 was the most resistant to general corrosion of the three candldate alloys and yet experlenced rates approached $4 \mathrm{mils}$ per year in the concentrated groundwater. However, corrosion rates for all materlais decreased with time. Thus, it is not clear whether general corrosion is a problem for the copper base alloys in the Tuff repository. With the addition of radiation, the general corrosion rates of pure copper (CDA 102) and aluminum bronze (CDA 614) elther decreased or experlenced moderate increases while Copper-30 nickel (CDA 715) experlenced the greatest increase.

It appears that the most serlous problem for the long term performance of copper base alloys is locallized corrosion. Results of potentlodynamic polarization experiments on CDA 715 in $\mathrm{J}-13$ water at $80^{\circ} \mathrm{C}$ Indicate a high probability of pltting. Signlficant hysteresis was observed and the value

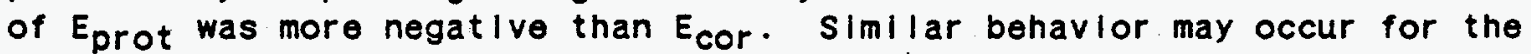
other candidate copper base alloys but protection potentlals for those alloys in $J-13$ well water were not reported. 
Results of recent research performed at Cortest Columbus Indlcate that great care should be taken in interpreting the results of electrochemical studles performed on the copper base alloys in Tuff environments. On CDA 102 copper, two distinct types of corrosion processes have been assoclated with essentlally identical polarization curves. In several simulated groundwaters, potentlodynamlc polarization curves containing hysteresis have been obtalned. In one environment, the hysteresis on the reverse scan was correlated with classlcal pitting. However, in several other environments, the hysteresis was assoclated with reglons of passive film color change on the specimen, without apparent Increases in rates of attack. This color change may be associated with a change in oxidation state of the $f 1 / \mathrm{m}$ (e.g. from $\mathrm{Cu}^{+}$to $\mathrm{Cu}^{++}$) and/or may represent the early stages of $\mathrm{fl} \mathrm{Im}$ breakdown.

Results of electrochemlcal studies indlcated that thermal concentration of the groundwater and temperature Increases actually decreased the IIkellhood of pltting of the copper base alloys. In related electrochemical studies, a radiation fleld only promoted modest detrimental shifts in electrochemical pitting parameters. On the other hand, pitting and crevice corrosion were observed on specimens of the three candidate copper base alloys exposed in a radiation fleld under simulated repository conditlons. The attack was most severe in the vapor phase where corrosive radiolytlc specles may have formed; a condition not examined in the electrochemical studies. This apparent discrepancy between the short term electrochemical results and actual long term exposures points out the need to confirm any short term test results.

LIke Fe-Cr-NI alloys, copper base alloys are susceptible to MIC. A varlety of organisms has been Implicated in promoting pitting of copper base alloys in natural waters and underground environments. MIC is not likely to be a problem in the repository untll after the thermal perlod when radiation levels are low.

No SCC of copper base alloys has been reported in tests in $\mathrm{J}-13$ well water with or without radlation for exposure perlods up to 14 months. Historlcally, stress corrosion cracking of copper base alloys has been observed in numerous environments including sulfates, nitrates, nitrites, ammonium, humld air and steam. It is generally established that pure copper and copper-nickel alloys are more resistant to stress corrosion cracking than are most other copper base alloys. However, these alloys are susceptlble to stress corrosion cracking in several cracking environments. In splte of the apparent good stress corrosion cracking performance in the above tests, cracking remalns as a potentially serlous problem for the copper base alloys. 


\section{RECOMMENDATIONS}

As described in the introduction, this report summarizes the results of a Ilterature survey performed under Task 1 of Cortest columbus' program on "Long Term Performance of Container Materlals Used For HIgh Level Waste Packaglng". Part of the purpose of Task 1 is to complle repository site specific data that are necessary to develop and update the work $p l a n$ and to provide continulty between individual tasks of the project. In this section of the report, the objectives and approach for each of the experImental tasks of the program are summarlzed, along with recommendations for carrying out the task, based on the revlew of the literature.

\subsection{Task 2-Potent lodynamlc Polarization studies}

The purpose of Task 2 is to examine the effects of environmental varlables and welding on the electrochemlcal behavlor of candldate waste contalner materials. Potentlodynamlc polarization technlques are belng used to determine the polarization parameters for characterizing general and locallzed corrosion. The specific varlables which are being examined in this task Include (1) concentration of the chemical species in the environment, (2) temperature effects, and (3) effects of welding.

Because of the large matrix of tests necessary to evaluate these var 1ables, a statistical experimental design approach is being used. The survey of the literature was used to define the compositional limits for the experimental matrix of potentlodynamic polarization curves. Included In the analysis was consideration of thermal and radiation effects on groundwater composition. Justification for the compositional ranges selected are given in Appendlx B.

\subsection{Task 3-Vapor Phase Corrosion studles}

Based on the survey of the literature, It appears that the vapor phase, in the presence of condensed water, may be the most aggressive environment for the waste contalner. As described in Section 5.1.3, SCC of solution annealed Types 304L stainless steel occurred in the vapor phase above $\mathrm{J}-13$ well water in the presence of radiation. The copper base alloys underwent pltting, crevice corrosion and dealloying under simllar test conditions.

Thus, the focus of this task will be to evaluate the corrosion performance of the candidate contalner materlals in the vapor phase in the presence of specles generated by radlolysis.

\subsection{Task 4-Pitting studies}

The purposes of this task are:

(1) to study the relationships between the pltting parameters $E_{p}$ lt and $E_{p r o t}$ and long-term pit initlation behavior of Type $304 \mathrm{~L}$ Stainiess steel, and

(2) to evaluate the plt propagation behavior of the copper base alloys. 
Current waste package designs for the Tuff repository utillze thin stalnless steel containers. Thus, If plts Inltlate, contalner fallure by pltting corrosion will occur in a relatively short time perlod. Accordingly, resistance to pit initlation is critical for the adequate performance of a stalnless steol contalner. DOE is utllizing electrochemical technique to assess the IIKellhood of plt Inltiation for stalnless steels In simulated Tuff repository environments. The critlcal parameters used in the evaluation are $E_{p r o t .} E_{p l t}$ and $E_{\text {cor. }}$. It is assumed that if $E_{\text {cor }}$ is far away from $E_{p r o t}$ and $E_{p \mid t}$. pltting is unlikely to Initiate in a given environment. In thls subtask, the relatlonship between long-term pltting behavlor and these parameters wlll be assessed by means of potentlostatlc polarlzation tests.

One Interesting aspect of the electrochemlcal studies performed in $\mathrm{J}-13$ well water and in concentrated $\mathrm{J}-13$ well water is the resistance of the austenitic stainless steels to pitting corrosion in splte of the rela$t$ ively $h$ igh concentration of aggressive species such as $\mathrm{Cl}$. This resistance is probably attributable to the high concentrations of corrosion inhlbitors such as blcarbonates in the solution. As described in section 2.3, a radiation fleld may greatly decrease the concentration of these benef.clal species in the groundwater. Similarly, the beneflclal specles may not be present in adequate concentrations in condensed phases. Thus, part of the plt inltiation studies wlll be performed in dilute solutions representative of the above conditions.

Results of potentiodynamic polarlzation studies described in Section 3.2.2. have shown that plts readily Initlate on the copper base alloys in Tuff groundwater. Accordingly, for a copper contalner to provlde adequate containment, it must be demonstrated that the rates of $p / t$ propagation are low in comparison to the contalner wall thickness. In this subtask, pit propagation experiments will be performed on two copper alloys in environments Identifled in Task 2 as most likely to promote pltting.

\subsection{Task 5-Stress Corrosion Cracking Studles}

The purpose of Task 5 is to Identify the environmental conditions under which the candldate alloys wlll undergo stress corrosion cracking (SCC). A slow strain rate (SSR) technlque will be used for evaluating SCC. This technique Involves the slow straining of the materlal in the suspected environment.

A key aspect of this task will be the Identiflcation of the species responsible for the vapor phase SCC of solution annealed Type 304L stainless steel in a radiation fleld, as described in section 5.1.3. Once this fallure has been reproduced, the resistance of other $\mathrm{Fe}-\mathrm{Cr}-\mathrm{NI}$ alloys to SCC in this environment can be evaluated.

For the copper base alloys, the most likely cracking agents are the nitrogen compounds generated by radiolysis. Accordingly, SSR tests on the copper base alloys will focus on solutions containing credible levels of these agents. 


\subsection{Task 6-Other Fallure Modes}

The purpose of Task 6 is to explore fallure modes whlch are llkely, according to current knowledge, to produce accelerated attack and may lead to premature fallure of the waste container. Several fallure modes will be brlefly examined to determine whether any merlt more detalled examlnation. The following fallure modes have already been Ident ifled for examination In this task: (1) thermogalvanlc couples, (2) dealloying of copper alloys, (3) metallurglcal effects In stainless steels, and (4) borehole IIner - container Interactlons. During the course of this research program, it is likely that other potentlal fallure modes will be identifled and included in this task.

Dealloying of CDA 613 was Identifled in long-term exposure studies in the presence of a radiation fleld, as described in section 5.2.2. Similar behavlor may occur for CDA 715. Based on the above results, the dealloying studies will focus on the effects of radlolysis products on dealloylng of the copper base alloys.

As described in section 3.1.2, the role of sensitization of the $\mathrm{Fe}-\mathrm{Cr}-\mathrm{NI}$ alloys on the pltting resistance has not been studled for the Tuff repository. Thus, under metallurglcal effects in stalniess steels, this phenomenon wlll be investigated.

It is clear from an examination of Section 6-Mlcroblologlcal Effects on Corrosion, that MIC potentlally is a serlous problem for the long-term performance of the repository. Research in this area is not within the scope of this program. However, it is recommended that NRC develop and maintain a program in this area.

\subsection{Task 7-Long-Term Exposure Studies}

The purpose of Task 7 is to provide long-term exposure data for evaluating the various modes of corrosion Identlfled. These experlments will highlight plt propagation and stress corrosion cracking, as well as other fallure modes determined to significantly accelerate corrosion. The specific environments used for study in this task will depend on the results of Task 2 through 6 . The experiments performed in these tasks will, In turn, be gulded by this summary of the literature, as described above. Of course, the work $p l a n$ and experimental designs wlll be updated as experimental results become available from this program and other pertinent programs. 
Numerous technlques are avallable for the evaluation of the corrosion behavior of metallic materlals. These include simple potentlal measurement technlques, as well as galvanostatic, galvanodynamic, potentlostatlc and potentlodynamic technlques. In galvanostatlc and galvanodynamic techniques, the current is the control varlable while the potential is the measured varlable; whereas, the opposite is true for the potentlostat lc and potent lodynamic polarization technlques. The major difference between the potentlostatic and potentlodynamic polarization technlques is that discrete potentlals are selected in the former; whereas, the potential is scanned in the latter. For passive metals such as stalnless steel, the current control techniques are not well sulted and thus, are not discussed further.

In the potentlodynamic polarization (PP) procedure, the polarity and magnltude of the current density between a metal specimen and an inert counter electrode are measured as a function of electrochemical potential. A polarlzation curve is then plotted as potentlal versus logar ithm of current density. For the anodic portions of the curve*, the current measured is equal to the corrosion rate of the specimen if two conditions are met: (1) the over-potentlal (difference between the free-corrosion potentlal and polarlzed potentlal) is large enough such that the rate of the cathodlc reaction is negliglble, and (2) the rates of parasltlc oxidation reactions are negliglble.

A schematic of anodic polarization curves showing several types of behavior Is given In FIgure A.1. For the active-corrosion case, the anodlc curve is I inear on a potentlal versus logarithm of current (E-log 1) plot, and the forward and reverse scans are colncident. The presence of a peak in the anodlc portion of the curve, followed by decreasing current, generally Indicates the onset of passivation. The occurrence of hysteresis between the forward and reverse scans indlcates pltting. Eplt corresponds to the potentlal at whlch plts initlate (pltting potentlal) while Eprot corresponds to the potentlal at which propagating plts repassivate (protection potentlal). Where the hysteresis loop is very large (Eplt - Eprot is large), Eprot may be very close to the free-corrosion potentlal, Ecor, Indlcating a high probabllity of pitting in service.

The potentlodynamic polarization technique also has been found to be useful in identifying possible stress corrosion cracking (SCC) environments for some al loy-environment systems; e.g. carbon steel in caustic. For carbon steel, it has been shown that SCC is assoclated with environments that promote active-passive behavior and that the range of electrochemical potentlals that promote SCC is near to and more noble (positive) than $E_{\max }$. Moreover, it has been observed that severe cracking occurs in environments where I max on the fast scan is greater than about $1 \times 10^{-3} \mathrm{~A} / \mathrm{cm}^{2}$ and where

* An anodic current is defined as current leaving the metal surface and passing into the solution. 


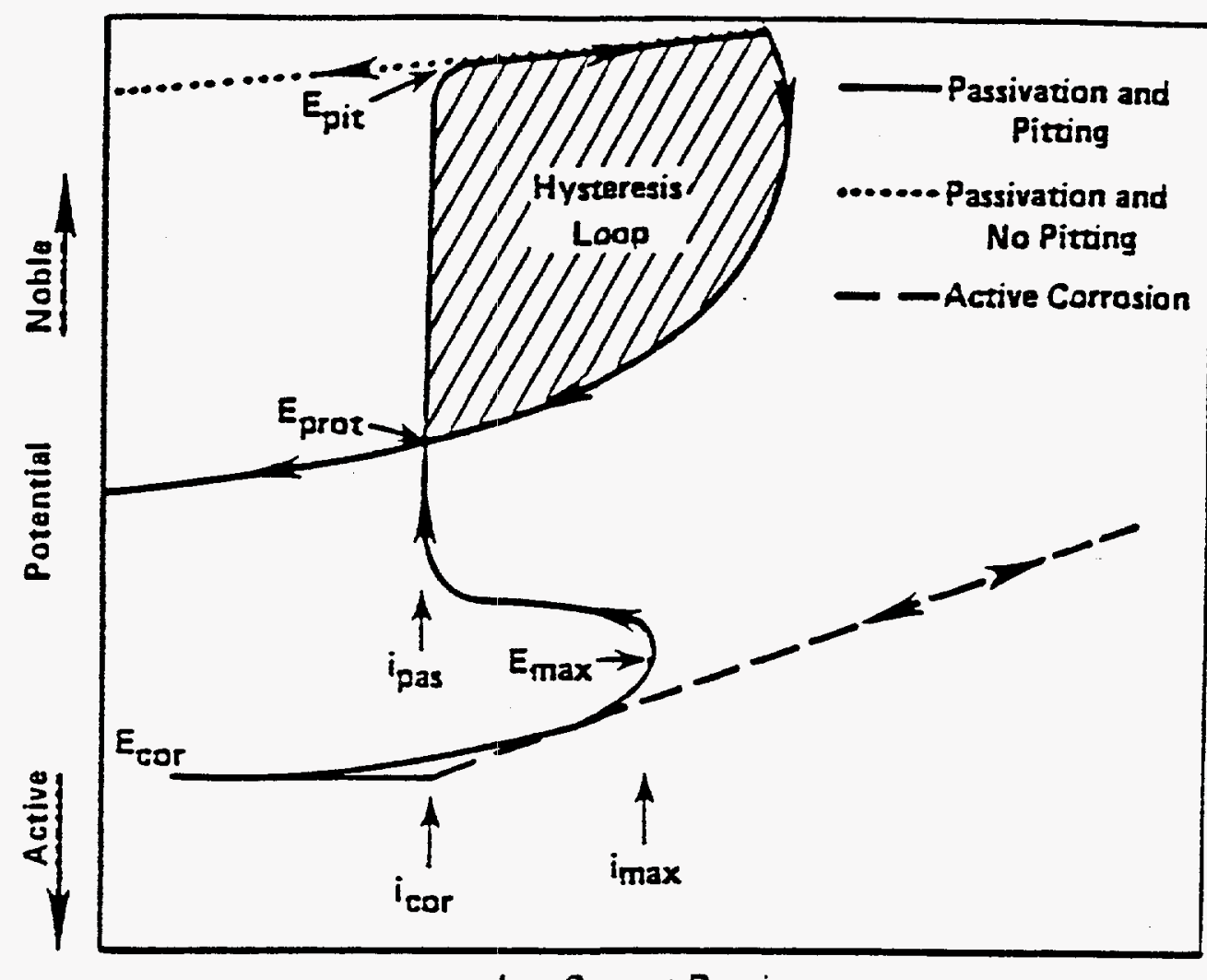

Log Current Density

$E_{\text {cor }}=$ corrosion potential; $i_{c o r}=$ current density at the free-corrosion potential; $E_{\max }=$ potantial at the active peak; $i_{\max }=$ current density at active peak; $i_{\text {pas }}=$ current density in passive range; $E_{p i t}=$ potential at which pits initiate on forward scan; and $E_{\text {prot }}=$ potential at which pits repassivate on reyerse scan.

Figure A.1 Schematic of Typlcal Anodlc Potent lodynamic Polar lzation curves. 
the fast scan exhlbits currents at least an order of magnltude higher than those of the slow scan. A slow scan for detecting pltting corrosion is typlcally run at $0.6 \mathrm{~V} /$ hour; whereas, a fast scan for detecting SCC may be several orders of magnitude faster.

A PP curve is obtalned using a potentlostat, a function generator, a reference electrode, such as a standard calomel electrode, and an approprlate test cell. A potentlostat is a three-electrode device consisting of reference electrode, work Ing electrode and aux IIIary electrode leads. The working electrode lead is connected to the test specimen while the auxlllary electrode lead is connected to an inert electrode such as platinum or graphlte placed in the test cell. The reference electrode lead is connected to the reference electrode which usually communicates with the test cell electrolyte through a small diameter tube fllled with electrolyte, referred to as a Luggin probe or salt bridge. One tip of the probe is placed near the test specimen to mInimize measurement errors due to ohmlc potentlal drops, while the other end is usually placed is an beaker contalning the electrolyte and the reference electrode. A typical test arrangement is shown in Figure A.2.

The potentlostat is an electrical feedback device which obtains the desired potential, measured between the reference electrode and the metal specimen (working electrode), by flowing the approprlate current between the auxlllary electrode and the working electrode. Therefore, In a PP test, the control parameter is potentlal and current in the Independent parameter. The actual PP curve is obtalned by interfacing the potentlostat with the function generator and adjusting the generator to the desired potentlal scan rate. 


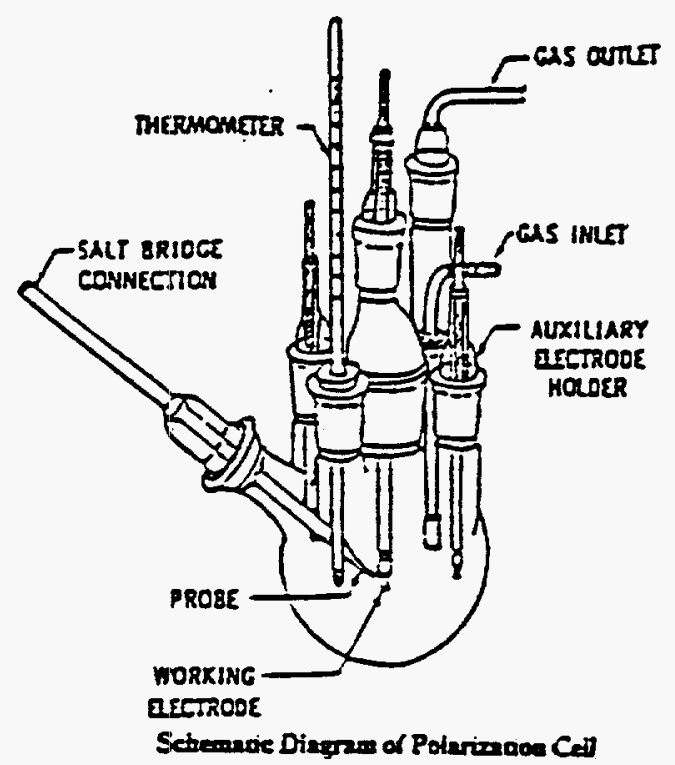

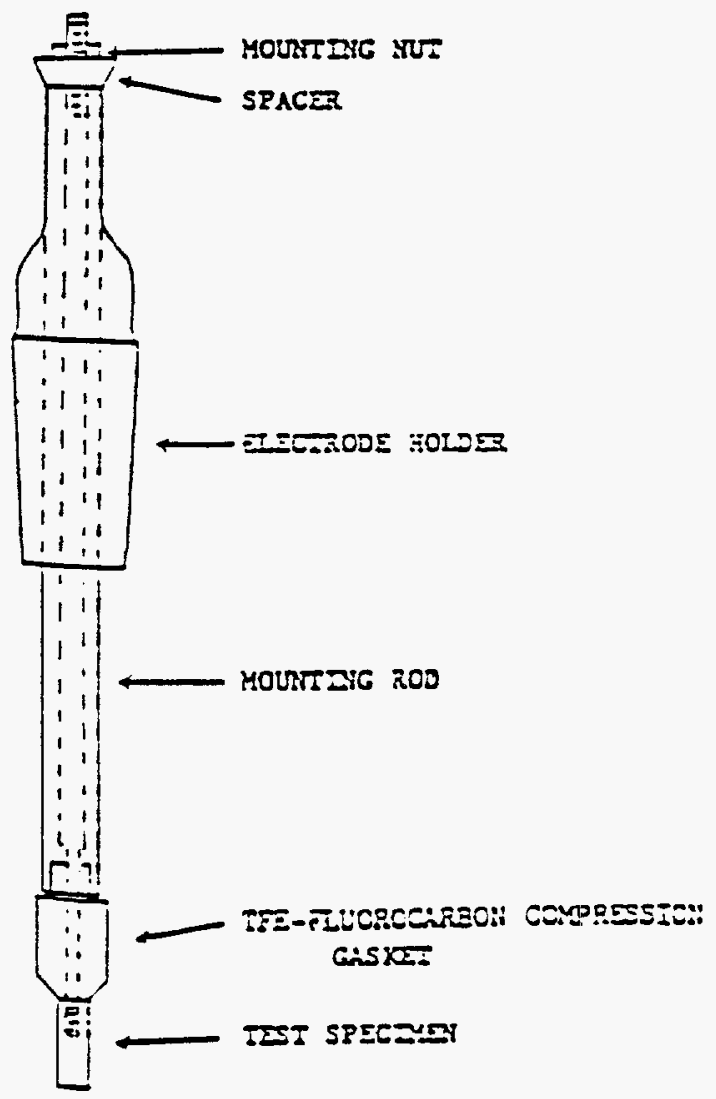

Speamen Mounsed on Eecorode Holder

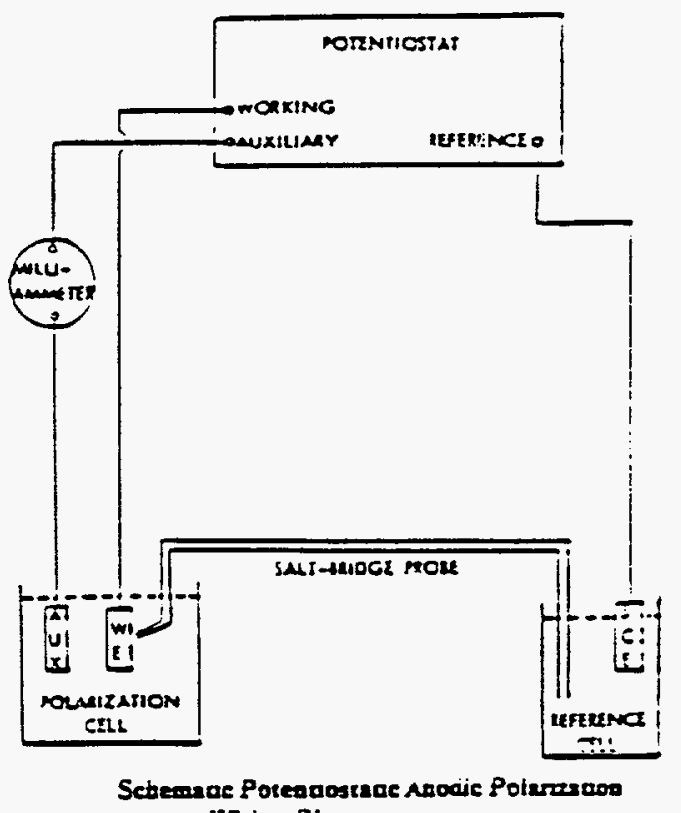

Wrise Diegum

Flgure A.2 Typlcal Test Equlpment for Performing The PP Test. 
Compositional Ranges Selected For Evaluation In Task 2 of The Experimental Program.

Table B.1 presents the compositional ranges of Important environmental specles for (1) Tuff groundwater, and (2) Tuff groundwater heated to temperatures from $90-150 \mathrm{C}$ in the presence of radlation.

The fifteen environmental varlables to be included in the experimental matrix and thelr $\mathrm{hlgh}$ and low concentrations are glven in Table B.2. The flfteen varlables selected for examination in these tests include twelve varlables assoclated with the J-13 groundwater and three varlables produced by radiolysis. NItrogen, sulfate, and sodlum wlll be the gas, anlon and cation, respectively, used for balancing the solution chemistry. One varlable that is missing from the fifteen environmental varlables IIsted In Table B.1 is the radlolysis product hydrogen. Because of the experlmental difflcultles in $m i x i n g$ hydrogen and oxygen, it was declded to remove hydrogen from the matrix of experiments and to perform a few experIments separately to establish its effect.

In the following paragraphs, each varlable is brlefly discussed and Justification for inclusion of the varlable into the matrix and the concentrations selected are presented. In general, a concentration factor of 200X was selected except where solubllity IImItations or other experimental data justifled some other range.

Silicon, Si, is present in the J-13 well water at a concentration of 58 $\mathrm{mg} / \mathrm{l}$. Data by Knauss $-1985 \mathrm{a}$ and Oversby-1983 Indlcate that, at $90 \mathrm{C}$, this is the approximate steady-state concentration which likely represents the solublilty IImlt of $S I$ at $90 \mathrm{C}$. During radlation, Yunker-1986a found that the concentration of Si decreased to a value of 0.5 to $1.5 \mathrm{mg} / \mathrm{l}$. Because of this, a low concentration of $1 \mathrm{mg} / \mathrm{l}$ was selected. A high concentration of $100 \mathrm{mg} / \mathrm{l}$ provides a factor of $100 \mathrm{x}$ between the low and high concentration examined. Also, the $100 \mathrm{mg} / \mathrm{l}$ concentration is $1 / \mathrm{kely}$ to exceed the solublilty limit such that the high concentration primarlly insures that saturation is attained during the high concentration tests.

Blcarbonate, $\mathrm{HCO}_{3}$, is present in the J-13 well water at a concentration of $125 \mathrm{mg} / \mathrm{l}$. Heat Ing the $\mathrm{J}-13$ well water in the presence of Tuff rock at $90 \mathrm{C}$ produced an increase in the concentration to $190 \mathrm{mg} / \mathrm{l}$ (Knauss-1985a and Oversby-1983) while radlation tended to decrease the concentration to 8-20 $\mathrm{mg} / \mathrm{l}$ (Yunker-1986a). Therefore, a low concentration of $10 \mathrm{mg} / \mathrm{I}$ was selected and a factor of $200 x$ was used to provide a high concentration of $2,000 \mathrm{mg} / \mathrm{l}$.

Fluorlde, $F$, was present in the J-13 well water at a concentration of 2.2 $\mathrm{mg} / \mathrm{l}$. Heating In the presence of Tuff rock (Knauss-1985a and Coversby1983) resulted In a very slight increase In $F$ concentration. Radiation produced a slight decrease in $F$ concentration to 0.4-1.4 mg/l (Yunker1986a). Based on these results, a $1.0 \mathrm{mg} / \mathrm{l}$ low concentration was selected and a factor of $200 x$ provides a high concentration of $200 \mathrm{mg} / \mathrm{l}$. 
Table B.1 Concentration Ranges For Environmental

Specles In Tuff Groundwater

Nom Ina I Concentration of

Environmental Varlable

$\mathrm{pH}$

S I

$\mathrm{HCO}_{3}$

$\mathbf{F}$

CI

$\mathrm{NO}_{3}$

$\mathrm{SO}_{4}$

$\mathrm{NO}_{2}$

$\mathrm{H}_{2} \mathrm{O}_{2}$

Al

Fe

$\mathrm{Ca}$

$\mathrm{Mg}$

K

$\mathrm{Na}$ $\mathrm{mg} / \mathrm{I}$

7.6

58

125

2.2

6.9

9.6

18.7

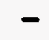

0.012

0.006

12.5

1.9

5.1

44
Concentration Range of Groundwater Heated

To 90-250C with Tuff Rock, $(a, b) \mathrm{mg} / \mathrm{l}$

$$
5.8-8.3
$$$$
29-394
$$$$
45-195
$$

$2.2-4.4$

$6.5-8.9$

$8.5-16.8$

$13.3-22$

$0.7-1.5$

$0.016-4.8$

$0.21-13.2$

$0.009-2.0$

$3.2-19.4$

$35-74$
Concentration Range of Groundwater Heated To 90/150C In Presence of Radlation(c), $\mathrm{mg} / \mathrm{l}$

$$
7.6-9.0
$$

$0.49-1.45$

$8.1-21$

$0.38-1.4$

$2.5-5.8$

$2.5-18.8$

$1.8-6.2$

$1.2-3.8$

$0-4.8^{(d)}$

$<0.15-0.18$

$<0.02-0.04$

$2.7-9.8$

$0.6-1.1$

$2.4-4.8$

$2.8-36$

(a) Knauss, 1985.

(b) Oversby, 1983.

(c) Yunker, 1986 .

(d) Glass, 1985. 
Table B.2 List of Varlables To Be Included In the Resolution IV Matrix of Potent lodynamlc Polarlzation Tests In Task 2.

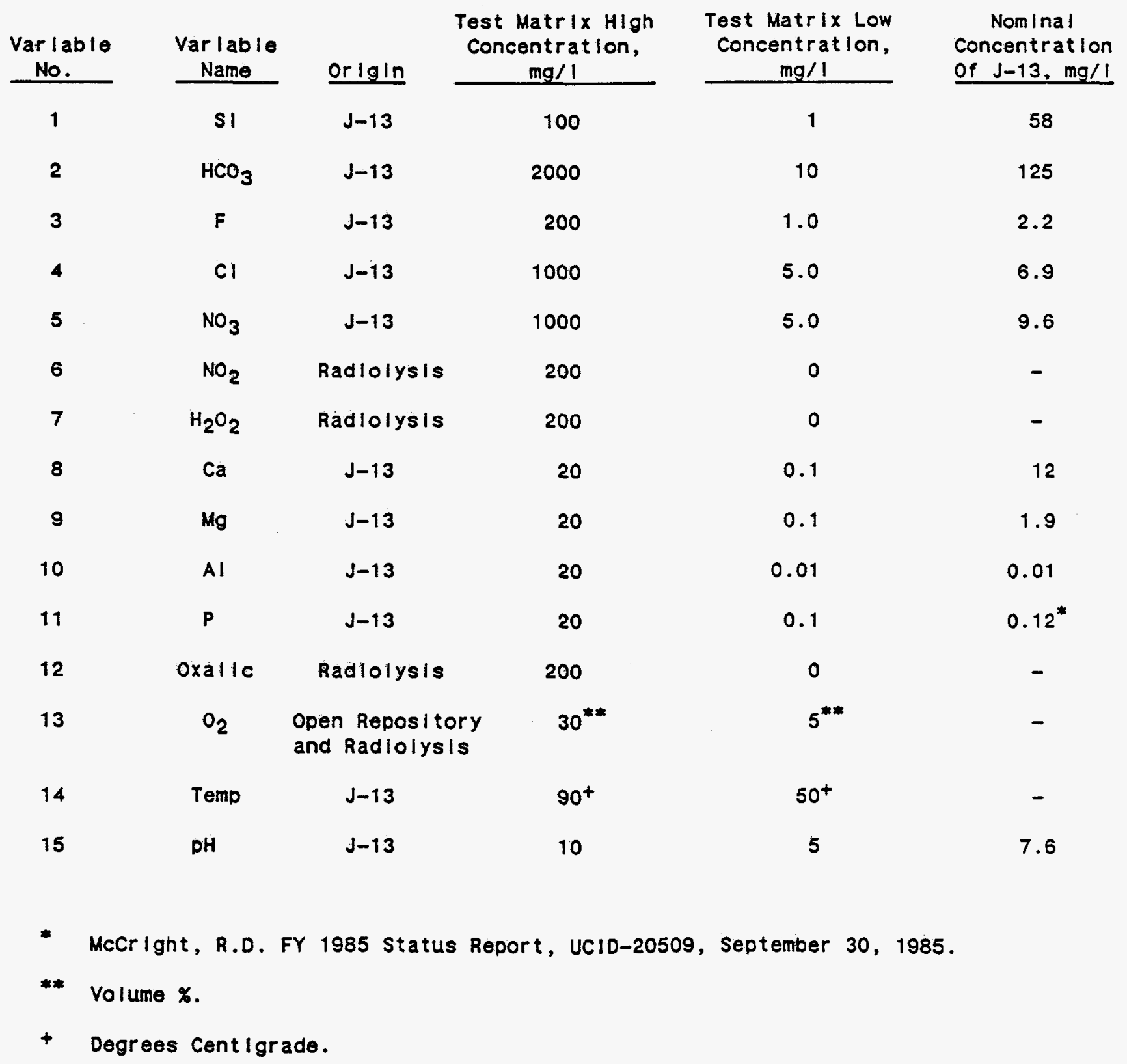


Chloride, $\mathrm{Cl}$, is present in the $\mathrm{J}-13$ well water at a concentration of 7 $\mathrm{mg} / \mathrm{l}$. Heating of the $\mathrm{J}-13$ well water In the presence of Tuff rock produced little or no change in the $\mathrm{Cl}$ concentration. The effect of radlation was to produce a slight decrease in the $\mathrm{Cl}$ concentration to 2.5-5.8 mg/l (Yunker-1986a). The low concentration was selected at $5 \mathrm{mg} / \mathrm{l}$ and a factor of $200 x$ increase provides a high concentration of $1,000 \mathrm{mg} / 1$.

Nitrate, $\mathrm{NO}_{3}$, is present in the $\mathrm{J}-13$ well water at a concentration of 10 $\mathrm{mg} / \mathrm{l}$. Very little change was observed in the $\mathrm{NO}_{3}$ concentration upon heating In the presence of Tuff rock (Knauss-1985a and Oversby-1983). In the presence of radiation, the $\mathrm{NO}_{3}$ concentration varled from 2.5 to 19 $\mathrm{mg} / 1$ (Yunker-1986a). Thereby, no systemat lc increase or decrease in the $\mathrm{NO}_{3}$ concentration was observed. The low concentration for $\mathrm{NO}_{3}$ was selected at $5 \mathrm{mg} / \mathrm{l}$ and a factor of $200 x$ provides a high concentration of $1,000 \mathrm{mg} / \mathrm{l}$.

Nitrite, $\mathrm{NO}_{2}$, is a radlolysis product whlch has been shown to achieve concentratlons from 0.7 to $3.8 \mathrm{mg} / \mathrm{l}$ (Yunker-1986a). The low concentration for $\mathrm{NO}_{2}$ is 0 . A high concentration of $200 \mathrm{mg} / \mathrm{l}$ was selected and is approximately 50x the concentration indlcated by Yunker-1986a.

Peroxlde, $\mathrm{H}_{2} \mathrm{O}_{2}$, is a radlolys is product and was shown to achleve a concentration of $5 \mathrm{mg} / \mathrm{I}$ in the presence of radlation by Glass-1986a. The low concentration was selected as 0 and $a$ hlgh concentration was selected at $200 \mathrm{mg} / \mathrm{l}$ which provides a factor of approximately $40 x$ over the concentration Indlcated by Glass-1986a.

Calclum, Ca, is present in the J-13 well water at a concentration of 12 $\mathrm{mg} / \mathrm{l}$. The concentration of Ca changed $11 \mathrm{ttl}$ e when the $\mathrm{J}-13$ well water was heated in the presence of Tuff rock at 90C. At higher temperatures, the $\mathrm{Ca}$ concentration decreased to $0.2 \mathrm{mg} / \mathrm{l}$. In the presence of radlation, the concentration of $\mathrm{Ca}$ decreased to $2-9.8 \mathrm{mg} / \mathrm{l}$ (Yunker-1986a). The low concentration for $\mathrm{Ca}$ was selected at $0.1 \mathrm{mg} / \mathrm{l}$ and a factor of $200 \mathrm{x}$ provides a $\mathrm{hlgh}$ concentration of $20 \mathrm{mg} / \mathrm{l}$.

Aluminum, Al, is present in the $J-13$ well water at a concentration of 0.01 $\mathrm{mg} / \mathrm{l}$. Upon heat Ing the J-13 well water in the presence of Tuff rock, the Al concentration Increased to $2-3 \mathrm{mg} / \mathrm{I}$ (Knauss-1985a). In the presence of radiation, the Al Increased to $0.18 \mathrm{mg} / \mathrm{I}$ (Yunker-1986a). Therefore, a much larger range of concentration was observed for Al than was observed for other specles. Thereby, a low concentration of 0.01 was selected and a factor of $2,000 x$ provides a high concentration of $20 \mathrm{mg} / \mathrm{l}$.

Phosphorus, $P$, has been reported at a concentration of $0.12 \mathrm{mg} / \mathrm{I}$ in $\mathrm{J}-13$ well water (MCCrlght-1985) and has not been reported, at all, in other referenced $\mathrm{J}-13$ well waters. The low concentration for $P$ was selected to be $0.1 \mathrm{mg} / \mathrm{l}$ and a factor of 200 provides a high concentration of $20 \mathrm{mg} / \mathrm{l}$.

Organic aclds have been reported as naturally occurring in ground waters (Means-1987) and have been indlcated as possible radiolysis products (Glass-1986a). For this study, oxallc acld was selected as the organic acld to examine. The low concentration or oxallc acld will be 0 and the high concentration for oxalic acld will be $200 \mathrm{mg} / \mathrm{l}$ which corresponds to the concentration range of other radiolysis products. 
oxygen, $\mathrm{O}_{2}$. is present in the repository because of its location above the water table and because no alr tight sealing arrangement is proposed for the repository. It is likely that the concentration of $\mathrm{O}_{2}$ could be somewhat less than that normally occurring in alr and, on the high side, could be greater than that occurring in alr due to radiolysis (Glass1985). The low concentration of $\mathrm{O}_{2}$ was selected at 5 volume $\mathrm{x}$ and the hlgh concentration at 30 volume $x$.

Because the repository design will not permit any significant pressure buildup, the aqueous phase corrosion, which is being examined in this task, has a 1 Imiting temperature at the bolling point of the $\mathrm{J}-13$ well water. The low temperature to be examined was selected at $50 \mathrm{C}$ and the high temperature was selected at $90 \mathrm{C}$. The high temperat $r$ re of $90 \mathrm{C}$ was selected to provide a temperature near bolling but than can be controlled relatively easily and accurately in the laboratory.

The $\mathrm{pH}$ of the J-13 well water is slightly alkallne, having been reported at $\mathrm{pH}$ 7.6. Upon heating of the J-13 well water In the presence of Tuff rock, the $\mathrm{pH}$ varled only slightly when heated at $90 \mathrm{C}$ and decreased down to 6.0 when heated at 250C (Knauss-1985a). In the presence of radiation, the pH has been observed to Increase to 9.0 (Yunker-1986a). To provide a somewhat larger range of $\mathrm{pH}$ for the test matrix, the low $\mathrm{pH}$ was selected at 5 and the $h i g h \mathrm{pH}$ was selected at 10 .

Potassium wlll be malntalned at a constant value of $5 \mathrm{mg} / \mathrm{l}$ throughout the test since it is not expected to have a major influence on the corrosion behavior of the alloys being tested. For balancing the solution chemistry, sodium and sulfate, as well as the nitrogen concentration of the purging gas, wlll be permitted to vary during the tests. 
Acton-1986 - Acton, C. F. and McCright, R. D., "Feasibllity Assessment of Copper-Base Waste Package Contalner Materlals In A Tuff Repository" Lawrence Livermore Natlonal Laboratory, UCID-20847, September, 1986.

Abraham-1986 - Abraham, T., Jaln, H., and Soo, P., "Stress Corrosion Cracking Tests on High-Level-Waste Contalner Materlals In Simulated Tuff Repository Environments", Brookhaven National Laboratory, NUREG/CR-4619, BNL-NUREG-51996, June, 1986.

Alanis-1986 - Alanis, I., Berardo, L., De Cristofaro, N., Moina, C., Valentinl, C., "A Case of Locallzed Corrosion In Underground Brass Pipes", Instituto Nacional de Tecnologla Industrlal, Blologically Induced Corrosion, NACE-8, p. 102, Edltor: S. C. Dexter, Published In 1986.

Allen-1961 - Allen, A. 0., "The Radlation Chemlstry of Water And Aqueous Solutions", D. Van Nostrand and Co., Inc., Princeton, N.J., 1961.

Anderson-1984 - Anderson, C, Brewster, C., Davis, M. S., Gause, E. P., Jaln, H., Pescatore, C., Sastre, C., Soo, P., Sulllivan, T., "Review of Waste Package Verification Tests BlAnnual Report", Brookhaven Nationa! Laboratory, NUREG/CR-3091, BNL-NUREG-51630, Vol. 6, July, 1985.

Andresen-1981 - Andresen, P. L., et. al., "Baslc Studles on The Varlabillties of Fabrication-Related Sensitization Phenomena In Stalnless Steels", EPRI FInal Report NP-1823.

Beavers-1980 - Beavers, J. A., Agrawal, A. K., Berry, W. E., "CorroslonRelated Fallures In Power Plant Condensers", Battelle, Columbus Laboratorles, Electric Power Research Institute Final Report NP-1468, August, 1980.

Beavers-1988 - Beavers, J. A., Thompson, N. G., "Contalner Corrosion In HIgh Level Nuclear Waste Repos/torles", Cortest Columbus, Inc., Second Seml-Annual Report, Year 1, March, 1988 - August, 1988, under Contract No. NRC-04-87-009, NRC FIN 01692 for U. S. Nuclear Regulatory Comm.

Belttie-1967 - Beittle, I. R. "NItrogen Dloxide And Dinitrogen Tetraoxide", In Mellow, Comprehensive Treatise on Inorganic and Theoretical Chemistry, v. VIII, Suppl. II (J. Wlley and Sons, New York, NY), p. 246.

Bengough-1924 - Bengough, G. D., May, R., J. Inst. Metals, Vol. 32, p. 81.

Benjamin-1983, Benjamin, L. A., Hardle, D. and Parkins, R. N., University of Newcastle-Upon-Tyne, England, Report No. 83-06/SKBF/KBS.

Blbler-1986 - Blbler, N. E., "Leaching Fully Radloactive SRP Nuclear Waste Glass In Tuff Groundwater In Stainless Steel Vessels", E. 1. du Pont de Nemours \& Co., Savannah River Laboratory, DP-MS-85-141, DE86-015704. 
Broll-1977 - Broll, A., and Holtan, H., "Determinatlon of Characteristlc PItting Potentlals For AlumInum By Use of The Potentlostatlc Methods", Corrosion Sclence, 17, p. 59-69, (1977).

Fletcher-1970 - Fletcher, A. W. "Copper Recovery From Low-Grade Ore By Bacterlal Leaching", Chapter 8 Microblal Aspects of Metallurgy, Amerlcan Elsevier Publishing Co. (1970).

Forsythe-1942 - Forsythe, W. R. and Glaque, W. F., Jour. Amer. Chem. Soc. $64,48,(1942)$.

Fox-1983 - Fox, M. J., and McCright, R. D., "An Overvlew of Low Temperature Sensitization", Lawrence Livermore National Laboratory, Livermore, CA, UCRL-15619, DE85-001078, December, 1983.

Glass-1984 - Glass, R. S., Overturf, G. E., Garrison, R. E., McCright, R. D., "Electrochemical Determination of The Corrosion Behavior of Candidate Alloys Proposed For Containment of HIgh Level Nuclear Waste In Tuff", Lawrence LIvermore National Laboratory, LIvermore, CA, UCID-20174, June, 1984.

Glass-1985 - Glass, R. S., Overturf, G. E., Van Konynenburg, R. A., and McCright, R. D., "Gamma Radlation Effects On Corrosion: I Electrochemical Mechanisms For The Aqueous Corrosion Processes of Austenitic Stalnless Steels", Lawrence LIvermore Natlonal Laboratory, Livermore, CA, UCRL-92311, February, 1985.

Glass-1986a - Glass, R. S., Van Konynenburg, R. A., and Overturf, G. E., "Corrosion Processes of Austenitlc Stainless Steels And Copper-Based Materlals In Gamma-Irradlated Aqueous Environments", Corroslon-86, Paper No. 258 and Lawrence Livermore Natlonal Laboratory, Livermore, CA, UCRL-92941, September, 1985.

Glass-1986b - Glass, R. S., Overturf, G. E., Van Konynenburg, R. A. and McCrIght, R. D., "Gamma Radlation Effects On Corrosion - 1. Electrochemlcal Mechanisms For The Aqueous Corrosion Processes of Austenitic Stalnless Steels Relevant To Nuclear Waste Disposal In Tuff", Lawrence Livermore National Laboratory, Corrosion Science, Volume 26, No. 8 , pp. 577-590.

Glassley-1986 - Glassley, W. E., "Reference Waste Package Environment Report", Lawrence Livermore National Laboratory, LIvermore, CA, UCRL-53726, October 1, 1986.

Graf-1969 - Graf, L., "Stress Corrosion Cracking In Homogeneous, NonSupersaturated Alloys Containing Noble Or No Noble Metals". Fundamental Aspects of Stress Corroslon CrackIng, Eds. Staehle, R. W., et. al., NACE 1969, p. 197.

Grant-1924 - Grant, R., Bate, E., and Meyers, W. H., Inst. Eng. Australia, SIdney DIV., Paper No. 8.

Gudas-1978 - Gudas, J. P., Hack, H. P., "Parametric Evaluation of SusceptIbllity of Cu-NI Alloys To Sulfide Induced Corrosion", Corrosion 78, Paper No. 22 (March 6-10, 1978) Houston, TX. 
Henne-1982 - Henne, M. S., "The DIssolut Ion of Ranler Mesa Volcanlc Tuff, And Its Application To The Analysis of The Groundwater Environment", M.S. thesls, University of Nevada, Reno, NV.

Herbert-1971 - Herbert, K, Australasian Corrosion Englneering, Apr II, 1971.

Hochanadel-1952 - Hochanadel, C. J., J. Phys. Chem., Volume 56, p. 57.

Jaln-1984 - Jaln, H., Veakls, E., Soo, P., "Revlew of Waste Package Ver Iflcation Tests", Brookhaven Natlonal Laboratory, NUREG/CR-3091, BNL-NUREG-51630, Vol. 5 , June, 1985.

Johnson-1966 - Johnson, H. E., LeJa, J., "Surface Chemlcal Factors In The Stress Corrosion Cracking of Alpha-Brass", Corrosion, Vol. 22, p. 178.

Johnstone-1981 - Johnstone, J. K. and Wolfsberg, K., edltors, "Evaluation of Tuff As A Medium For A Nuclear Waste Repository: Interim Status Report On The Propertles of Tuff", Sandla Natlonal Laboratorles, SAND80-1464, July, 1981.

Jones-1959 - Jones, A. R., "Radlation-Induced Reactions In The $\mathrm{N}_{2}-\mathrm{O}_{2}-$ $\mathrm{H}_{2} \mathrm{O}$ System", Rad. Res. 10, 655.

Juhas-1984 - Juhas, M. C., McCright, R. D., Garrison, R. E., "Behavior Of Stressed And Unstressed 304L Specimens In Tuff Repository Environmental Conditlons", Lawrence Livermore Natlonal Laboratory, LIvermore, CA, UCRL-91804, November, 1984.

Kawash Ima-1977 - Kawash Ima, A., Agrawal, A. K. and Staehle, R. W., "Stress Corrosion Cracking of Admiralty Brass In Nonammonlacal Sulfate Solutions", J. Electrochem. Soc., Vol. 124, p. 1822.

Kawash Ima-1979 - Kawashima, A., Agrawal, A. K. and Staehle, R. W., "Stress Corrosion Cracking - The slow Strain Rate Technlque" Uglansky, G. M, Payer, J. H., ASTM STP 665, Amerlcan Soclety For Testing And Materials.

Klement-1959 - Klement, J. F., Maersch, R. E. and Tully, P. A., Metal Progress, 75, (2), p. 83 .

Knauss-1983 - Knauss, K. G., Oversby, V. M., Holery, T. J., "Post Emplacement Environment of Waste Packages", Lawrence Livermore National Laboratory, Livermore, CA, UCRL-89475, DE84-004288.

Knauss-1984a - Knauss, K. G., Belriger, W. B., "Report On Statlc Hydrothermal Alteration Studies of Topopah Spring Tuff Wafers in J-13 Water At $150^{\circ} \mathrm{C} "$ ", Lawrence Livermore Nat lonal Laboratory, Livermore, CA, UCRL-53576, August, 1984.

Knauss-1984b - Knauss, K. G., Delany, J., BelrIger, W. J. and Peifer, D. "Hydrothermal Interaction of Topopah Spring Tuff With J-13 Water As A Function of Temperature", Lawrence Livermore National Laboratory, LIvermore, CA, UCRL-90853, November, 1984. 
Knauss-1984c - Knauss, K. G., "Hydrothermal Interaction Studles of Bullfrog Member Tuff Core Wafers in J-13 Water At $150^{\circ} \mathrm{C}$ : Quantltative Analyses of Aqueous And Solld Phases", Lawrence Livermore Natlonal Laboratory, Livermore, CA, UCRL-53521, DE84-014422, February, 1984.

Knauss-1985a - Knauss, K. G., BelrIger, W. J. and Pelfer, D. W., "Hydrothermal Interaction of Crushed Topopah Spring Tuff And J-13 Hater At 90,150 , and $250^{\circ} \mathrm{C}$ Using Dlcxson-Type, Gold-Bag Rocking Autoclaves", Lawrence LIvermore Natlonal Laboratory, LIvermore, CA, UCRL-53630, DE86-014752, May, 1985.

Knauss-1985b - Knauss, K. G., Belrlger, W. B., Pelfer, D. W., and Piwinskll, A., "Reaction of Solld Wafers Of Topopah Spring Tuff With $\mathrm{J}-13$ Water At 90,150 , and $250^{\circ} \mathrm{C}$ in DIckson-Type, Gold-5ag Rocking Autoclaves: 1. Short-Term Exper Iments, Lawrence Livermore Natlonal Laboratory, LIvermore, CA, UCRL-53645.

Kobrin-1986 - Kobrin, G., "Reflections On Microblologically Corrosion of Stainless steels", E. I. Du Pont de Nemours \& Co., Inc., Blologically Induced Corrosion, NACE-8, Editor: S. C. Dexter.

Logan-1983 - Logan, R. H., "Computer Simulation of Sensitization In Stainless Steels", Lawrence Livermore Natlonal Laboratory, Livermore, CA, UCID-20000, DE84-010622, December, 1983.

McCr Ight-1983 - McCrlght, R. D., Van Konynenburg, R. A., and Ballou, L. B., "Corrosion Test Plan To Gulde Canlster Material Selection And Design For A Tuff Repository", Lawrence Livermore National Laboratory, Livermore, CA, UCRL-89476, November, 1983.

McCright-1984-McCrlght, R. D., Welss, H., Juhas, M. C., and Logan, R. W. "Selection of Candldate Canister Materlals For HIgh-Level Nuclear Haste Containment In A Tuff Repository", Lawrence Livermore NatIonal Laboratory, LIvermore, CA, UCRL 89988 and Corrosion 84, Paper No. 198, Apr II, 1984.

McCright-1985 - McCright, R. D., "FY 1985 status Report On Feasibillty Assessment of Copper-Base Waste Package Container Materlals In A Tuff Repository", Lawrence LIvermore Natlona! Laboratory, LIvermore, CA, UCID-20509, September, 1985.

McDougall-1968 - McDougall, J., Australasian Corrosion Association 9th Annual Conference, 1968, paper 14.

Means-1987 - Means, J. L., et. al., "Long-Term Performance of HIgh-Level Glass Waste Forms", NUREG/CR-4795, BMI-2143, November, 1987.

Merz-1984 - Merz, M. D., Wang, R., "Test Methods To Predlct Long-Term Corrosion of Container Materlals Ir Repositories", Paciflc Northwest Laboratory, Rlchland, WA, PNL-SA-12326, DE85-004553, September, 1984. 
NIvens-1986 - Nivens, D. E., Nichols, P. D., Henson, J. M., Geesey, G. G., and Whlte, D. C., "Reverslble Acceleration of The Corrosion of Alsi 304 Stainless Steel Exposed To Seawater Induced By Growth And Secretions of The Marlne Bacterlum Vibrlo Natrlegens", Corrosion, Volume 42, No. 4, Apr II, 1986.

Ogard-1984 - Ogard, A. E. and Kerrisk, J. F., "Groundwater Chemistry Along Flow Paths Between A Proposed Repository Site And The Accessible Environment", Los Alamos Natlonal Laboratory, Los Alamos, NM, LA-10188-MS.

O'Neal-1983 - O'Neal, W. C., Rothman, A. J., Gregg, D. W., Hockman, J. N., RevelII, M. A., RusselI, E. H., Lawrence Livermore Nat Ional Laboratory, LIvermore, CA, and Schornhorst, J. R., Hest Inghouse Advanced Energy Systems Division, Pittsburgh, PA, "Design of A Nuclear-Waste Package For Emplacement in Tuff", UCRL-88192, DE83-006428.

O'Nea 1-1984 - O'Neal, W. C., Gregg, D. W., Hockman, J. N., Russell, E. W. and Stein, W., "Preclosure Analysis of Conceptual Waste Package Designs For A Nuclear Waste Repository In Tuff, Lawrence Livermore National Laboratory, Livermore, CA, UCRL-53595.

Oversby-1983 - Oversby, V. M., Knauss, K. G., "Reaction Of Bullfrog Tuff With $J-13$ Well Water At $90^{\circ} \mathrm{C}$ and $150^{\circ} \mathrm{C} "$, Lawrence Livermore National Laboratory, Livermore, CA, UCRL-53442, DE84-000659, September, 1983.

Oversby-1984a - Oversby, V. M., "Reaction Of The Topopah Spring Tuff With J-13 Water At $120^{\circ} \mathrm{C} "$, Lawrence Livermore Nat lonal Laboratory, Livermore, CA, UCRL-53574, July, 1984.

Oversby-1984b - Oversby, V. M., "Reaction of The Topopah Spring Tuff With $\mathrm{J}-13$ Well Water At $90^{\circ} \mathrm{C}$ and $150^{\circ} \mathrm{C} "$ ", Lawrence Livermore Nat lonal Laboratory, Livermore, CA, UCRL-53552, May, 1984.

Oversby-1984c - - Oversby, V. M. and McCright, R. D., "Laboratory Experiments Designed To Provide Limits On The Radionuclide Source Term For The NNWSi Project", Lawrence LIvermore Natlonal Laboratory, Livermore, CA, UCRL-91257, DE85-009952.

Oversby-1984d - Oversby, V. M., "Reference Waste Forms And PackIng Material For The Nevada Nuclear Waste Storage Investigations Project", Lawrence LIvermore National Laboratory, LIvermore, CA, UCRL-53531.

Oversby-1985 - Oversby, V. M., "The Reactlon Of Topopah Spring Tuff With J-13 Water at $150^{\circ} \mathrm{C}$ - Samples From Drill Cores USW G-1, USW GU-3, USW G-4, and UE-25h\#1", Lawrence LIvermore National Laboratory, LIvermore, CA, UCRL-53629, DE86-013160, March, 1985.

PItman-1986 - Pitman, S. G., Westerman, R. E., Haberman, J. H., "Corrosion And Slow Straln Rate Testing of Type 304L Stalnless Steel In Tuff Groundwater Environments", Paciflc Northwest Laboratory, Richland, WA, PNL-SA-14396, DE87-006404, October, 1986. 
Pope-1982 - Pope, D. H., Soracco, R. J., and WIlde, E. W., "Studies on Blologically Induced Corrosion In Heat Exchanger systems At The Savannah River Plant, Alken, SC", Corrosion/82, Paper No. 24, March, 1982, Houston, TX, and Materlals Performance, July, 1982.

Pope-1983 - Pope, D. H., Duquette, D. J., Johannes, A. H., and Wayner, P. C., "Mlcroblologically Influenced Corrosion of Industrlal Alloys", Corrosion/83, Paper No. 247, Apr II, 1983, Anahelm, CA, and Materlals Performance, Apr II, 1984.

Postgate-1979 - Postgate, J. R., "The Sulfate Reducing Bacterla, Cambridge University Press, 1979.

Puckorlus-1983 - Puckorlus, P. R., "Massive Utllity Condenser Fallure Caused By Sulfide Producling Bacterla", Corrosion/83, Paper No. 248 , Apr II, 1983, Anaheim, CA, and Materlals Performance, December, 1983.

Pugh-1969 - Pugh, E. N., Cralg, J. V., Sedriks, A. J., "The StressCorrosion Cracking of Copper, Sliver, And Gold Alloys", Proceedings on Fundamental Aspects of Stress Corrosion Cracking, 118-158, August, 1969.

Rogers-1948 - Rogers, T. H., J. InstItute of Metals, Volume 75, p. 19.

Russel I-1983a - RusselI, E. W., McCrlght, R. D., and O'Neal, W. C., "Containment Barrler Metals For High-Level Waste Packages in A Tuff Repository", Lawrence Livermore National Laboratory, Livermore, CA, UCRL-53449, October, 1983.

Russe 11-1983b - Russel1, E. W., McCright, R. D., O'Nea I, W. C., "Selection of Barrler Metals For A Waste Package In Tuff", Lawrence Livermore National Laboratory, LIvermore, CA, UCRL-89404, DE83-018182, September, 1983.

Sass-1982 - Sass, J. H. and Lachenbruch, A. H., "Hydrologic Implications of Preliminary Heat-Flow Data From The Nevada Test Site, EOS, Amerlcan Geophysical Unlon, Vol. 63, No. 45, November, 1982.

Sato-1974a - Sato, S., Nagata, K., "Stress Corrosion Cracking of Copper Alloys in Pure Steam And Water At High Temperatures", Boshoku GIJustu, Vol. 23, pp. 125-133.

Sato-1974b - Sato, S., Nagata, K., "Case Studles on The Failures of Copper And Copper Alloys By Stress Corrosion Cracking", Sumitomo Light Metal Technlcal Reports, Vol. 15:3, pp. 174-185, July, 1974.

Sato-1976 - Sato, S., Okawa, M., "Phenomenon And Controlling Factors of Mallgnant impingement Attack As The Maln Cause of Condenser Tube Failures", Sumitomo Light Metal Technical Reports, Vol. 17:1-2, pp. 17-27, January, 1976.

Sato-1978 - Sate, S., Nagata, K., "Factors AffectIng Corroslon And Foulling of Condenser Tubes of Copper Alloys And TItanlum", Sumitomo LIght Metal Technical Reports, Vol. 19:3-4, pp. 83-94, July, 1978. 
Schuraytz-1985 - Schuraytz, B., "Geochemical Gradlents In The Topopah Spring Member of The Palntbrush Tuff: Evidence For Eruption Across A Magmat Ic Interface", Lawrence Livermore Laboratory, LIvermore, CA, UCRL-53698.

SOo-1983 - S00, P., "Revlew Of DOE Waste Package Program", Erookhaven Nat lonal Laboratory, NUREG/CR-2482, BNL-NUREG-51494, Vol. 4.

Soo-1985 - Soo, P., "Revlew of Haste Package Veriflcatlon Tests", Brooxhaven National Laboratory, NUREG/CR-3091, BNL-NURES-51630, Vol. 7 , January, 1986.

Splnks-1976 - Splnks, J. W. T. and Hoods, R. J., "An Introduction To Radlation Chemistry, 2nd Edltion", John Wlley and Sons, New York.

Stefec-1979 - Stefec, R., Franz, F., and Holecek, A., "Effect of Heat Treatment on Pltting Corrosion of Austenltic Ciromlum-ivickelMolybdenum stee is In Sodium Chlorlde Solution", Herkstoffe und Korrosion, 30, (3), pp 189-197, March, 1979.

Stoecker-1984 - Stoecker, J. G., "Gulde for The Investigation of Mlcroblologlcally Induced Corroslon", Materlals Performance, August, 1984 and Corrosion/83, Paper No. 245, Anaheim, CA, Apr $11-1983$.

Stoecker-1986 - Stoecker, J. G., and Pope, D. H., "Study of Blological Corrosion In High Temperature Deminerallzed Water", Corrosion/86, Paper No. 126, Houston, TX, June, 1986 and Materlals Performance, June, 1986.

Tatna|1-1981a - Tatnall, R. E., "Fundamentals of Bacterla Induced Corrosion", Corrosion/81, Pacer No. 129, Toronto, Ontarlo, Apr ll, 1981, and Materlals Performance, September, 1981.

Tatnal1-1981b - Tatnall, R. E., "Case Historles: Bacter la Incuced Corrosion", Corrosion/81, Paper No. 130, Toronto, Ontarlo, April, 1981, and Materlals Performance, August, 1981.

Thompson-1944 - Thompson, D. H. and Tracy, A. H., Trans. AlME, 185, p. 100.

Travis-1984 - Travis, B. J., et. al., Los Alamos Natlonal Laboratory Report LA-UR-34-40.

Uhlig-1975 - Uhlig, H., Gupta, K., Llang, H., "Crltical Potentlals For Stress Corrosion Cracking of 63-37 Brass in Ammoniaca! And Tartrate Solutions", J. Electroctem. Soc., Vol. 122 343, March, 1975.

Van Konynenburg-1985 - Van Konynenburg, R. A. and Mccright, R. D., "Corrosion Performance of Metals And Alloys in A Tuff Geochemical Environment", Lawrence Livermore Natlonal Laboratory, LIvermore, CA, UCRL-91740, DEB5-009449.

Van Konynenburg-1986 - Van Konynenburg, R. A., "Radlation Chemical Effects In Experiments To Study The Reaction of Giass In A Gamma-irraclated Alr, Giolnowater, And Tuff Environment", Lawrence Livermore Vlat lonal Laboratory, LIvermore, CA, UCRL-53719. 
Helss-1985 - Weiss, H., Van Konynenburg, R. A., and McCright, R. D., "Metallurglcal Analysis of A 304L Stalnless Steel Canister From The Spent Fuel Test-CIImax", Lawrence Livermore Natlonal Laboratory, LIvermore, CA, UCID-20436, Apr II, 1985.

White-1980 - White, A. F., Claasen, H. C. and Benson, L. V., "The Effect of Dissolution of Volcanic Glass on The Water Chemistry in A Tuffaceous Aqulfer, Rainier Mesa, Nevada", U.S. Geological Survey, Denver, Co $1535-Q$.

WII cox-1981 - WIIcox, T.P. and Van Konynenburg, R. A., "Radlation Dose Calculations For Geologlc Medla Around Spent Fuel Emplacement Holes In The Climax Granite, Nevada Test Site", Lawrence Livermore National Laboratory, LIvermore, CA, UCRL-53159.

Yunker-1986a - Yunker, W. H., "Corrosion Of Copper-Based Materlals In Gamma Radiation", Westinghouse Hanford Company, HEDL-7612, DE87-005494, June, 1986.

Yunker-1986b - Yunker, W. H., Westinghouse Hanford Company, and Glass, R. S., Lawrence Livermore Nat lonal Laboratory, "Long-Term Corrosion Behavior of Copper-Base Materlals In A Gamma-Irradlated Environment", UCRL-94500, DE87-007098, December, 1986. 
(Sre instructions on the reverse)

Enviromental Effects on Corrosion in the Tuff Repository

Dr. J.A. Beavers, Dr. N.G. Thompson

Cortest Columbus, Inc.

2704 Sawbury Blvd.,

Columbus, $\mathrm{OH} 43235$

9. SPONSORING ORGANIZATION - NAME AND ADDRESS (II NRC, type "Same os sbove"; if contractor, provide NRC Division, Office or Region. U.S. Nutlear Regulatory Commission, and mailing address.)

Division of Engineering

Office of Nuclear Regulatory Research

U.S. Nuclear Regulatory Cormission

Washington, DC 20555

10. SUPPLEMENTARY NOTES

\section{ABSTRACT (200 words or less)}

Cortest Columbus is investigating the long-term performance of container materials used for high-level waste packages as part of the information needed by the Nuclear Regulatory Commission to assess the Department of Energy's application to construct a geologic repository for high-level radioactive waste: The scope of work consists of employing short-term techniques, such as electrochemical and slow strain rate mechanical test techniques, to examine a wide range of possible failure modes. Long-term tests are being used to verify and further examine specific failure modes identified as important by the short-term studies.

This report summarizes the results of a literature survey perfonned under Task 1 of the program. The survey focuses on the influence of enviromental variables on the corrosion behavior of candidate container materials for the Tuff repository. Envirommental variables considered included: radiation, thermal and microbial effects.

Corrosion

Thermal Effects

Radiation

Container Materials

Pitting

Stress Corrosion

Enviromental Effects
Microbial Influenced Corrosion

\begin{tabular}{|c|}
\hline $\begin{array}{l}\text { 13. AVAILABILITY STATEMENT } \\
\text { Unlimited }\end{array}$ \\
\hline 14. SECURITY CLASSIFICATION \\
\hline $\begin{array}{l}\text { This Page) } \\
\text { Unclassified }\end{array}$ \\
\hline This Report \\
\hline 15. NUMBER OF PAGES \\
\hline 16. PRICE \\
\hline
\end{tabular}

